\title{
Practical Ni-Catalyzed Aryl-Alkyl Cross-Coupling of Secondary Redox-active Esters
}

Josep Cornella ${ }^{\dagger \S}$ Jacob T. Edwards, ${ }^{\dagger \S}$ Tian Qin, ${ }^{\dagger}$ Shuhei Kawamura, ${ }^{\dagger}$ Jie Wang, ${ }^{\dagger}$ Chung-Mao Pan, ${ }^{\dagger}$ Ryan Gianatassio, ${ }^{\dagger}$ Michael Schmidt, ${ }^{\ddagger}$ Martin D. Eastgate, ${ }^{\ddagger}$ Phil S. Baran ${ }^{\dagger, *}$

\author{
${ }^{\dagger}$ Department of Chemistry, The Scripps Research Institute, \\ 10550 North Torrey Pines Road, La Jolla, California 92037 \\ ${ }^{7}$ Chemical Development, Bristol-Myers Squibb, \\ One Squibb Drive, New Brunswick, New Jersey 08903
}




\section{Table of contents}

General Considerations............................................ S3

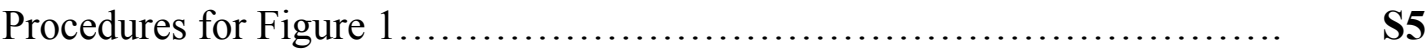

General Procedure for the synthesis of NHPI, NHS, TCNHP and pentafluorophenyl esters (General procedure A) ......................... S8

Graphical Supporting Information for the Synthesis of NHP Esters............ S20

General Procedure for the Preparation of Aryl Zinc Reagents from Aryl

Bromides.

Optimization details

General Procedure for the Ni-catalyzed Cross-coupling Reaction (General

Procedure B)

Gram-scale Procedure for the Ni-catalyzed cross-coupling (Heptan-3ylbenzene)....

Procedure and Characterization data

Mechanistic investigations

NMR Spectra.

Crystallographic data. 
General Considerations. Tetrahydrofuran (THF), N,N-dimethylformamide (DMF), and dichloromethane $\left(\mathrm{CH}_{2} \mathrm{Cl}_{2}\right)$ were obtained by passing the previously degassed solvents through an activated alumina column. Reagents were purchased at the highest commercial quality and used without further purification, unless otherwise stated. Nickel chloride glyme complex was purchased from Strem or Aldrich. Yields refer to chromatographically and spectroscopically ( ${ }^{1} \mathrm{H}$ NMR) homogeneous material, unless otherwise stated. Reactions were monitored by GC/FID, GC/MS, and thin layer chromatography (TLC). TLC was performed using $0.25 \mathrm{~mm}$ E. Merck silica plates (60F-254), using short-wave UV light as the visualizing agent or $\mathrm{I}_{2}$ or $\mathrm{KMnO}_{4}$ and heat as developing agents. NMR spectra were recorded on Bruker DRX-600, DRX-500, and AMX-400 instruments and are calibrated using residual undeuterated solvent $\left(\mathrm{CHCl}_{3}\right.$ at $7.26 \mathrm{ppm}{ }^{1} \mathrm{H}$ NMR, $\left.77.16 \mathrm{ppm}{ }^{13} \mathrm{C} \mathrm{NMR}\right)$ or TMS as an internal reference. The following abbreviations were used to explain multiplicities: $\mathrm{s}=$ singlet, $\mathrm{d}=$ doublet, $\mathrm{t}=$ triplet, $\mathrm{q}=$ quartet, $\mathrm{m}=$ multiplet, $\mathrm{br}=$ broad. Column chromatography was performed using E. Merck silica gel (60, particle size 0.043$0.063 \mathrm{~mm}$ ), and preparative TLC was performed on Merck silica plates (60F-254). High-resolution mass spectra (HRMS) were recorded on an Agilent LC/MSD TOF mass spectrometer by electrospray ionization time of flight reflectron experiments. Melting points were recorded on a Fisher-Johns 12-144 melting point apparatus and are uncorrected.

Handling of [Ni] catalysts.

All Ni catalysts were handled open to air on the bench top, and the bottles were not stored under inert atmosphere. The initial studies were conducted using $\mathrm{NiCl}_{2} \bullet$ glyme (Strem Chemicals, Inc., Lot \# B9633065) that was stored with no precaution to exclude air or moisture. Upon receiving a new bottle of $\mathrm{NiCl}_{2} \bullet$ glyme (Strem Chemicals, Inc., Lot \# 25608500), the yields for some substrates were slightly diminished by approximately $10-15 \%$. However, within a short period of $7-14$ days, the yields recovered. The color of the Ni catalyst changed from gold to a lighter yellow over this period of time (see below). 


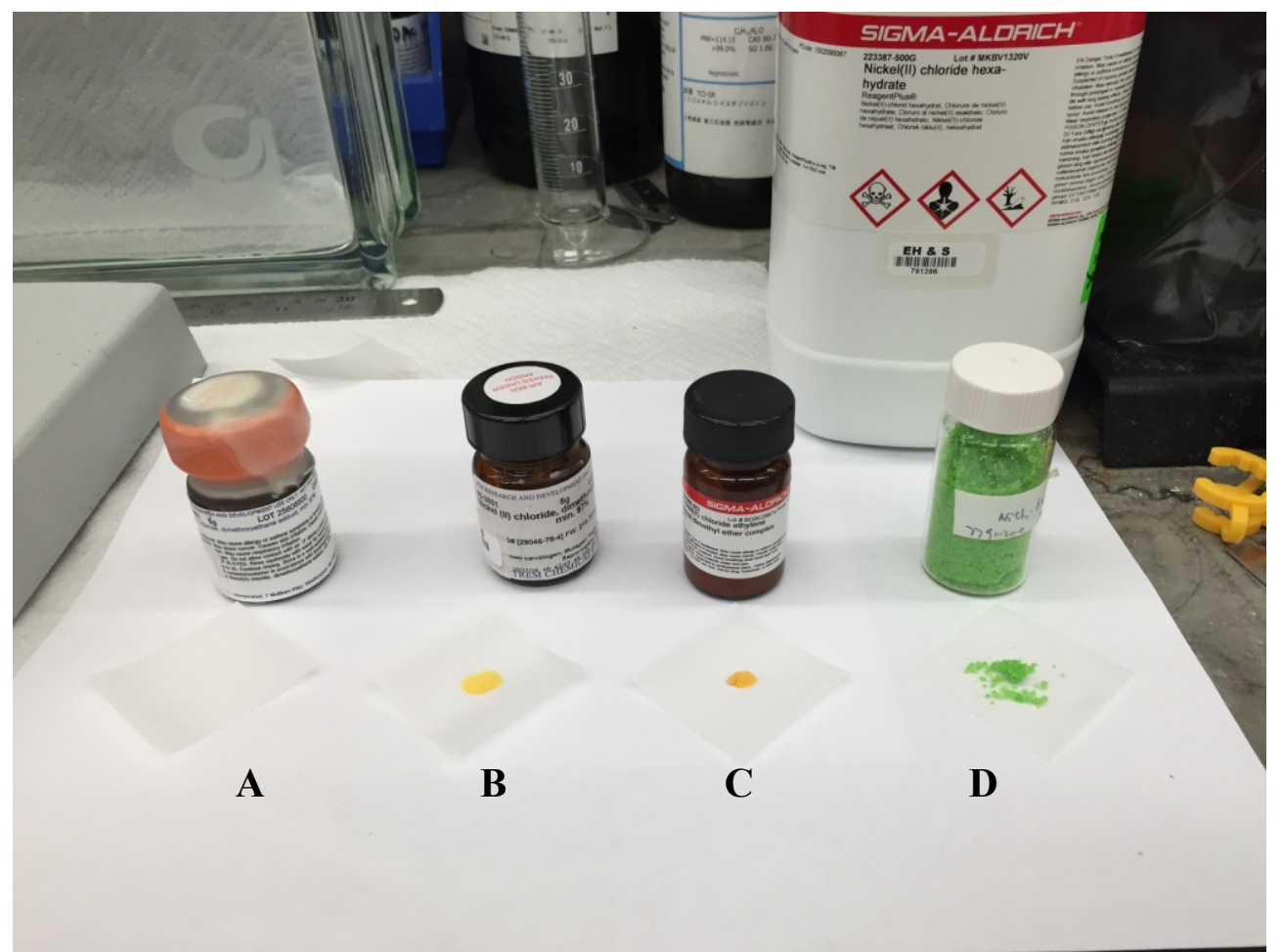

A: Unopened and wax-sealed bottle of $\mathrm{NiCl}_{2} \cdot$ glyme from Strem Chemicals, Inc. B: $\mathrm{NiCl}_{2} \cdot$ glyme (opened approx. 1 month ago) from Strem Chemicals, Inc. C: Bottle of $\mathrm{NiCl}_{2} \cdot g l y m e$ from SigmaAldrich. D: $\mathrm{NiCl}_{2} \cdot 6 \mathrm{H}_{2} \mathrm{O}$.

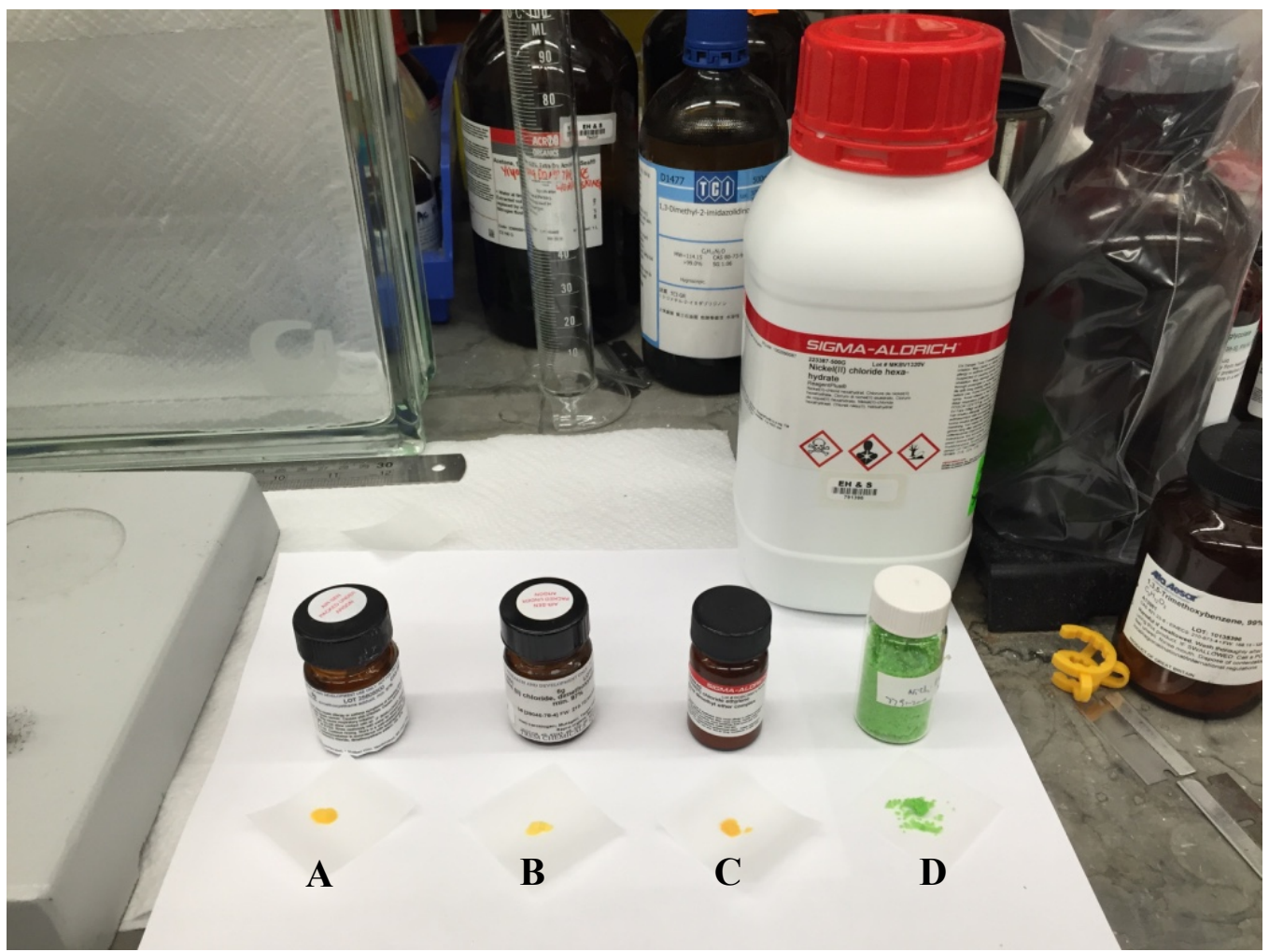

A: Recently opened bottle of $\mathrm{NiCl}_{2} \cdot$ glyme from Strem Chemicals, Inc. $\mathbf{B}$ : $\mathrm{NiCl}_{2} \cdot$ glyme (opened approx. 1 month ago) from Strem Chemicals, Inc. $\mathbf{C}$ : $\mathrm{NiCl}_{2} \cdot$ glyme from Sigma-Aldrich. D: $\mathrm{NiCl}_{2} \cdot 6 \mathrm{H}_{2} \mathrm{O}$. 


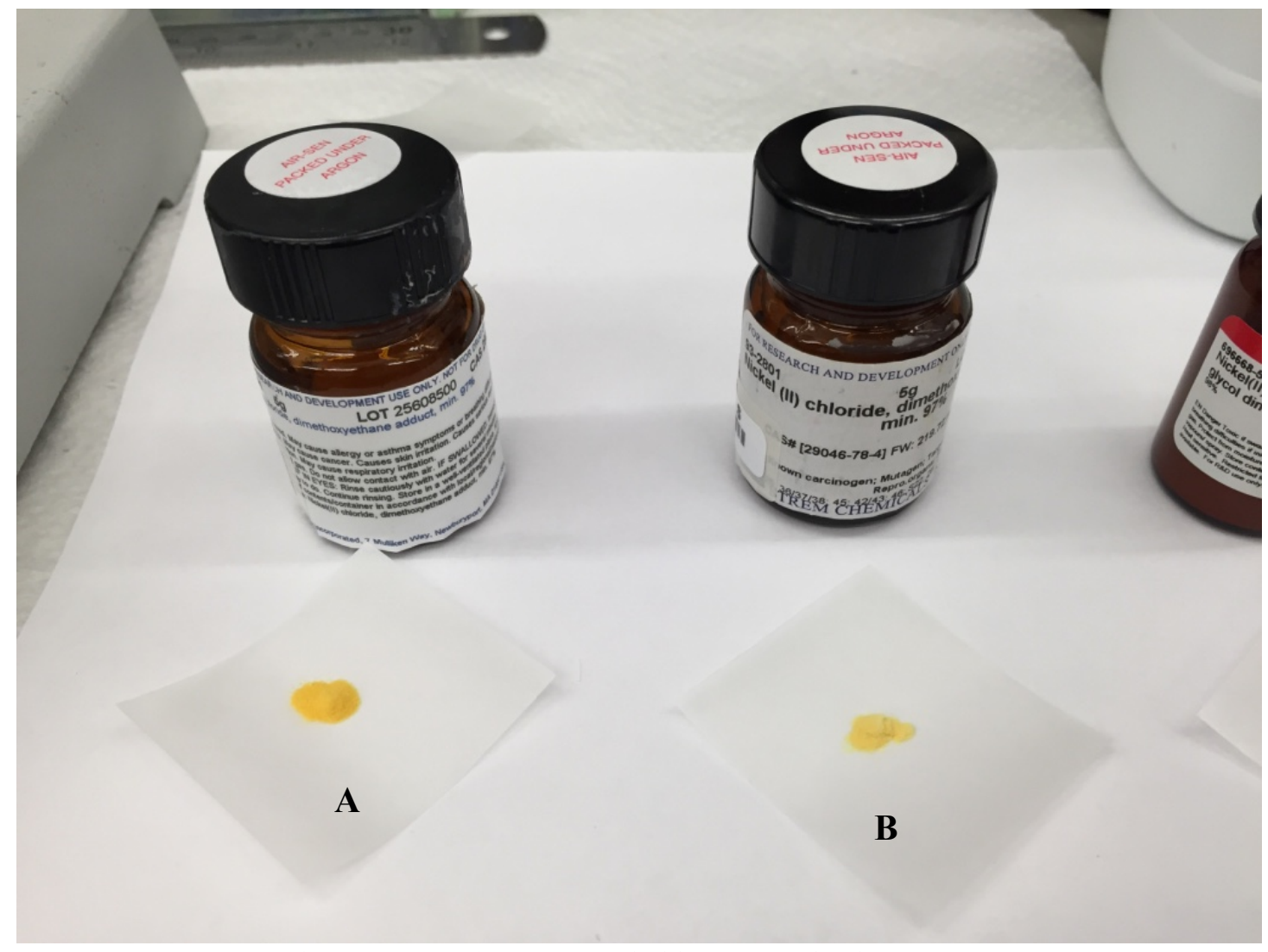

(Above) Comparison of appearance of new (A) and older (B) $\mathrm{NiCl}_{2} \bullet$ glyme.

\section{Procedures for Figure 1.}<smiles>CCC(Br)C(=O)On1ccccc1=S</smiles>

\section{2-Thioxopyridin-1(2H)-yl 2-ethylhexanoate}

Barton ester 1a was prepared following the literature procedure. ${ }^{1}$

In a round-bottom flask, 2-ethylhexanoic acid $(0.160 \mathrm{~mL}, 1.0 \mathrm{mmol}, 1.0$ equiv.) was dissolved in $\mathrm{CH}_{2} \mathrm{Cl}_{2}$ (anhydrous, $5.0 \mathrm{~mL}$ ). Oxalyl chloride was added $(0.10 \mathrm{~mL}, 1.1$ mmol, 1.1 equiv.), and the reaction was cooled to $0{ }^{\circ} \mathrm{C}$. DMF (anhydrous, $0.077 \mathrm{~mL}$, 0.1 equiv) was added. After 5 minutes, the reaction was warmed to rt and stirred until all bubbling ceased (approximately $1 \mathrm{~h}$ ). The flask was cooled again to $0{ }^{\circ} \mathrm{C}$ and wrapped in aluminum foil to shield the contents of the reaction vessel from light. DMAP (0.012 g, $0.1 \mathrm{mmol}, 0.1$ equiv.) and 2-mercaptopyridine $N$-oxide sodium salt $(0.149 \mathrm{~g}, 1.0 \mathrm{mmol}, 1.0$ equiv.) were added in succession. After $5 \mathrm{~min}$, the reaction was warmed to $\mathrm{rt}$ and stirred for 4 hours. The reaction was cooled to $0{ }^{\circ} \mathrm{C}$, and $\mathrm{H}_{2} \mathrm{O}$ (approx. $5 \mathrm{~mL}$ ) was added. The mixture was poured into a separatory funnel wrapped 
in aluminum foil, and the organic layer was washed with $\mathrm{H}_{2} \mathrm{O}$. The organic layer was dried over $\mathrm{Na}_{2} \mathrm{SO}_{4}$ and concentrated under reduced pressure in a water bath shielded from light at a temperature no higher than $25^{\circ} \mathrm{C}$. The crude product was purified by column chromatography (45:45:10 PhMe:DCM:EtOAc) to yield the title compound ( $0.080 \mathrm{~g}, 0.316 \mathrm{mmol}, 32 \%$ yield). During column chromatography both the column and fractions collected were covered as adequately as possible with aluminum foil to minimize exposure of the compound to light.

Physical State: yellow oil.

$\boldsymbol{R}_{\boldsymbol{f}}=0.20$ (4:1 hexanes:EtOAc).

${ }^{1}$ H NMR (600 MHz, $\left.\mathbf{C D C l}_{3}\right): \delta 7.69(\mathrm{ddd}, J=8.7,1.8,0.6 \mathrm{~Hz}, 1 \mathrm{H}), 7.48(\mathrm{ddd}, J=$ 7.0, 1.6, $0.6 \mathrm{~Hz}, 1 \mathrm{H}), 7.19$ (ddd, $J=8.7,6.8,1.6 \mathrm{~Hz}, 1 \mathrm{H}), 6.61(\mathrm{td}, J=6.9,1.8 \mathrm{~Hz}$, $1 \mathrm{H}), 2.70(\mathrm{tt}, J=7.9,5.7 \mathrm{~Hz}, 1 \mathrm{H}), 1.98-1.83(\mathrm{~m}, 2 \mathrm{H}), 1.81-1.71(\mathrm{~m}, 1 \mathrm{H}), 1.67$ (ddt, $J=13.8,9.8,5.8 \mathrm{~Hz}, 1 \mathrm{H}), 1.51-1.32(\mathrm{~m}, 4 \mathrm{H}), 1.06(\mathrm{t}, J=7.5 \mathrm{~Hz}, 3 \mathrm{H})$, and 0.93 (t, $J=7.2 \mathrm{~Hz}, 3 \mathrm{H})$.

${ }^{13}$ C NMR (151 MHz, $\left.\mathbf{C D C l}_{3}\right): \delta$ 176.2, 171.8, 137.8, 137.7, 133., 112.6, 44.7, 31.02, 29.4, 24.9, 22.7, 14.0, and 11.8.

HRMS (ESI-TOF): calc'd for $\mathrm{C}_{13} \mathrm{H}_{20} \mathrm{NO}_{2} \mathrm{~S}[\mathrm{M}+\mathrm{H}]^{+}$254.1209; found 254.1211.

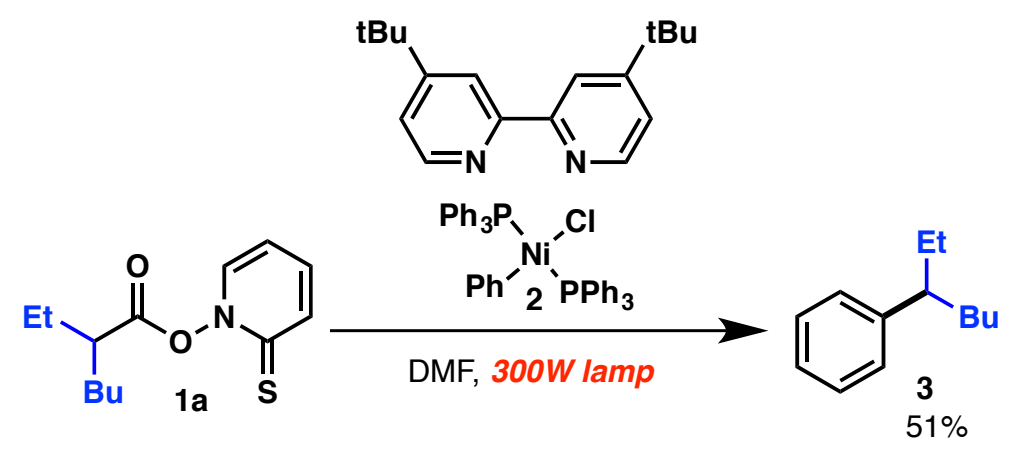

With a $300 \mathrm{~W}$ lamp: A $25 \mathrm{~mL}$ screw-top culture tube wrapped in aluminum foil was charged with Barton ester 1a (25 mg, $0.10 \mathrm{mmol}$ ) and DMF (anhydrous, $0.5 \mathrm{~mL}$ ) was added. In a separate $25 \mathrm{~mL}$ screw-capped culture tube, Ni-complex $\mathbf{2}^{2}$ (34.8 $\mathrm{mg}, 0.05$ mmol) and di- $t$ Bubipy $(13.4 \mathrm{mg}, 0.05 \mathrm{mmol})$ were dissolved in DMF $(1.0 \mathrm{~mL})$ under Ar atmosphere. After 5 minutes of stirring, the solution of $\mathbf{2}$ and di-tBubipy became homogenous, and the solution containing 1a was transferred to the Ni complex solution via syringe. The resulting mixture was immediately irradiated with a $300 \mathrm{~W}$ lamp. After 3 hours, the reaction was quenched with $1 \mathrm{M} \mathrm{HCl}$ (approx. $2 \mathrm{~mL}$ ) and diluted with $\mathrm{Et}_{2} \mathrm{O}$. Cyclooctane (1.0 equiv.) was added via micropipette. The mixture 
was diluted with EtOAc and an aliquot was removed, filtered through a short plug of silica gel, and analyzed by GC/FID.
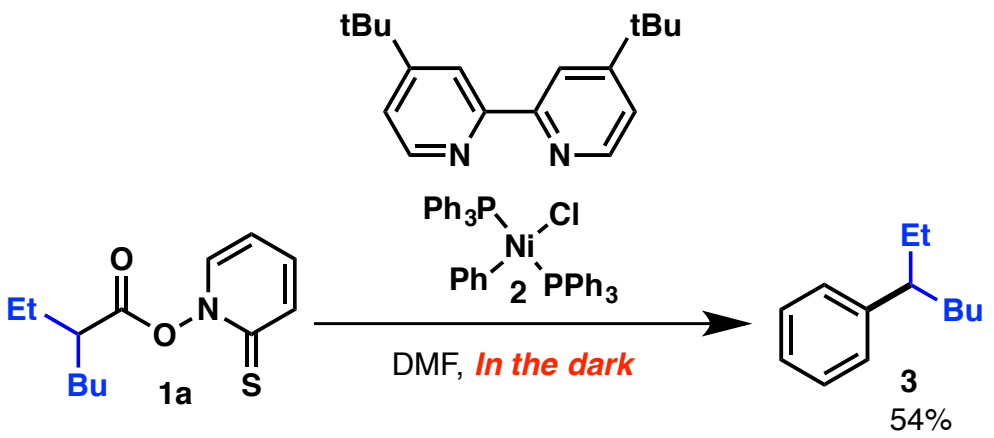

In the dark: A $25 \mathrm{~mL}$ culture tube was charged with Barton ester 1a ( $25 \mathrm{mg}, 0.10$ mmol). DMF (anhydrous, $0.5 \mathrm{~mL}$ ) was added, and the culture tube was wrapped with aluminum foil and sealed. In a separate $25 \mathrm{~mL}$ culture tube wrapped in aluminum foil, Ni-complex $2^{2}$ (34.8 mg, $\left.0.05 \mathrm{mmol}\right)$ and di-tBubipy (13.4 mg, $\left.0.05 \mathrm{mmol}\right)$ were dissolved in DMF (anhydrous, $1.0 \mathrm{~mL}$ ) under Ar. After 5 minutes the solution of 2 and di-tBubipy became homogenous, and the solution containing 1a was transferred to the Ni-complex solution via syringe. After 3 hours, the reaction was quenched with $1 \mathrm{M} \mathrm{HCl}$ (approx. $2 \mathrm{~mL}$ ) and diluted with $\mathrm{Et}_{2} \mathrm{O}$. Cyclooctane (1.0 equiv.) was added by micropipette. The mixture was diluted with EtOAc and an aliquot was removed, filtered through a short path of silica gel and analyzed by GC/FID.

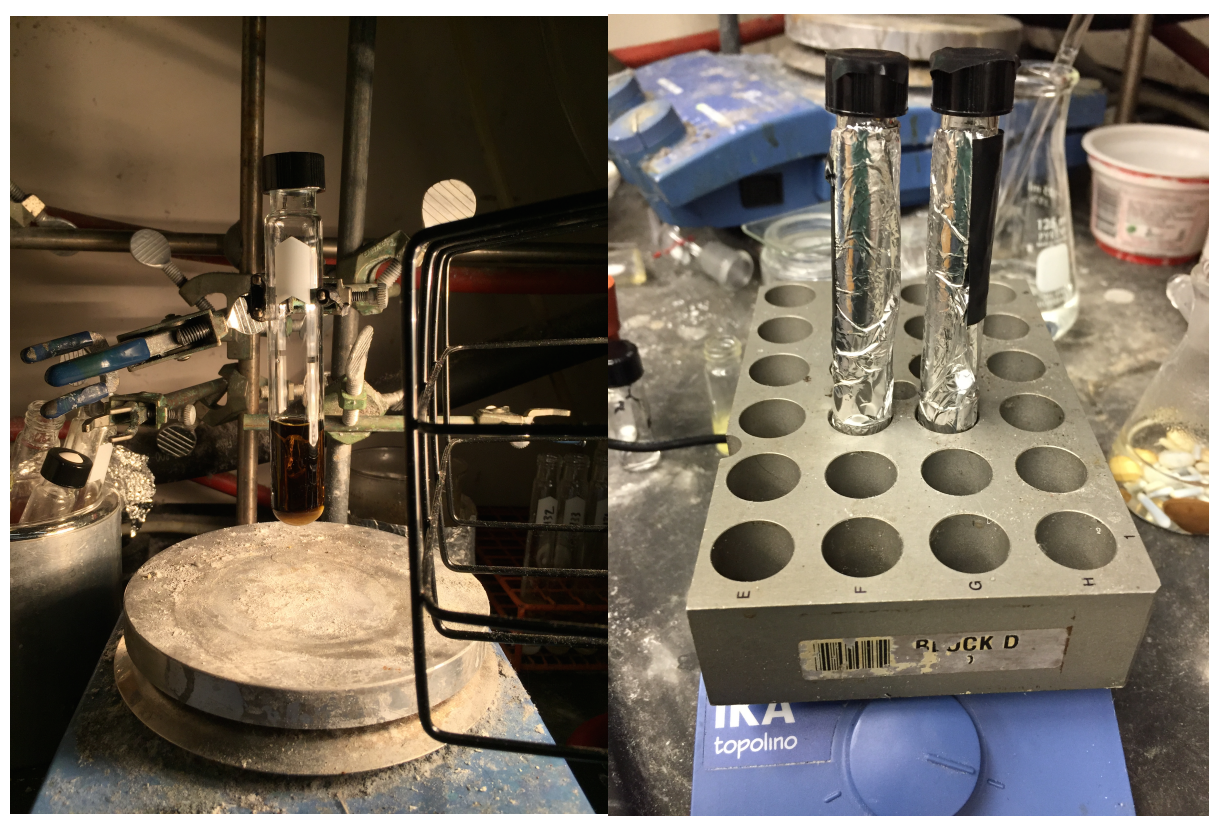

Left; reaction of $\mathbf{1 a}$ with $\mathbf{2}$ in the presence of di-tBubipy irradiated with a $300 \mathrm{~W}$ lamp. Right: reaction of $\mathbf{1 a}$ with $\mathbf{2}$ in the presence of di- $t$ Bubipy in the dark. 
General Procedure for the synthesis of NHPI, NHS, TCNHP and pentafluorophenyl esters (General procedure A).

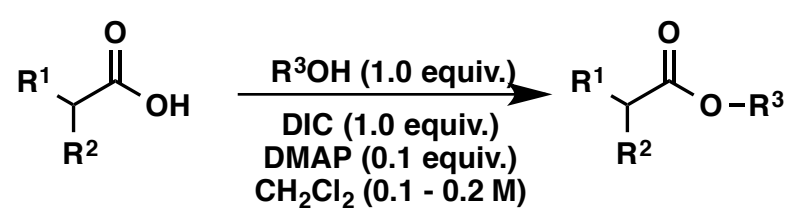

A round-bottom flask or culture tube was charged with (if solid) carboxylic acid (1.0 equiv), nucleophile ( $N$-hydroxyphthalimide, $N$-hydroxysuccinimide tetrachloro- $N$ hydroxyphthalimide ${ }^{3}$ or pentafluorophenol, 1.0 equiv) and DMAP (0.1 equiv). Dichloromethane was added $(0.1-0.2 \mathrm{M})$, and the mixture was stirred vigorously. Carboxylic acid (1.0 equiv) was added via syringe (if liquid). DIC (1.1 equiv) was then added dropwise via syringe, and the mixture was allowed to stir until the acid was consumed (determined by TLC). Typical reaction times were between $0.5 \mathrm{~h}$ and $12 \mathrm{~h}$. The mixture was filtered (over Celite, $\mathrm{SiO}_{2}$, or through a fritted funnel) and rinsed with additional $\mathrm{CH}_{2} \mathrm{Cl}_{2}$. The solvent was removed under reduced pressure, and purification by column chromatography afforded corresponding activated esters, which were used without further purification unless otherwise noted. Note: Some esters are prone to hydrolysis on silica gel during column chromatography and should be purified as quickly as possible to obtain reasonable separation.<smiles>CCC(Br)C(=O)Oc1c(F)c(F)c(F)c(F)c1F</smiles>

\section{Perfluorophenyl 2-ethylhexanoate}

Following the General Procedure A with 2-ethylhexanoic acid (320 $\mu \mathrm{L}, 2.0 \mathrm{mmol})$ and pentafluorophenol $(440 \mu \mathrm{L}, 2.2 \mathrm{mmol})$ in $\mathrm{CH}_{2} \mathrm{Cl}_{2}(10.0 \mathrm{~mL})$ at $\mathrm{rt}$ for $2 \mathrm{~h}$ afforded $570 \mathrm{mg}(92 \%)$ of the title compound after purification by column chromatography (9:1 hexanes:EtOAc).

Physical State: colorless oil.

$\boldsymbol{R}_{\boldsymbol{f}}=0.64$ (9:1 hexanes:EtOAc).

${ }^{1}$ H NMR (400 MHz, CDCl $)$ ): $\delta 2.77-2.55$ (m, 1H), $1.92-1.59$ (m, 4H), 1.40 (d, $J$ $=6.0 \mathrm{~Hz}, 4 \mathrm{H}), 1.05(\mathrm{td}, J=7.5,1.5 \mathrm{~Hz}, 3 \mathrm{H})$, and $0.98-0.87(\mathrm{~m}, 3 \mathrm{H})$.

${ }^{13}$ C NMR (101 MHz, CDCl 3 ): $\delta$ 171.8, 140.8 (m, 2C), $138.6(\mathrm{~m}, 1 \mathrm{C}), 136.6(\mathrm{~m}, 2 \mathrm{C})$, 124.7 (t, $J=14.3 \mathrm{~Hz}, 1 \mathrm{C}), 46.7,31.3,28.9,25.1,22.1,13.4$, and 11.1. 
HRMS (ESI-TOF): calc'd for $\mathrm{C}_{14} \mathrm{H}_{16} \mathrm{~F}_{5} \mathrm{O}_{2}[\mathrm{M}+\mathrm{H}]^{+}$311.1065; found 311.1066.<smiles>CCC(Br)C(=O)ON1C(=O)CCC1=O</smiles>

\section{2,5-Dioxopyrrolidin-1-yl 2-ethylhexanoate}

Following the General Procedure A with 2-ethylhexanoic acid (320 $\mu \mathrm{L}, 2.0 \mathrm{mmol})$ and $N$-hydroxysuccinimide $(0.230 \mathrm{~g}, 2.0 \mathrm{mmol})$ in $\mathrm{CH}_{2} \mathrm{Cl}_{2}(5.0 \mathrm{~mL})$ at $\mathrm{rt}$ for $2 \mathrm{~h}$ afforded $384 \mathrm{mg}(80 \%)$ of the title compound after purification by column chromatography (gradient elution, hexanes to 4:1 hexanes:EtOAc).

Physical State: colorless oil.

$\boldsymbol{R}_{\boldsymbol{f}}=0.27$ (4:1 hexanes:EtOAc).

${ }^{1}$ H NMR (600 MHz, $\left.\mathbf{C D C l}_{3}\right): \delta 2.82(\mathrm{~d}, J=10.1 \mathrm{~Hz}, 4 \mathrm{H}), 2.58(\mathrm{tt}, J=8.8,5.4 \mathrm{~Hz}$, $1 \mathrm{H}), 1.81-1.63(\mathrm{~m}, 3 \mathrm{H}), 1.59(\mathrm{ddt}, J=13.7,10.1,5.6 \mathrm{~Hz}, 1 \mathrm{H}), 1.48-1.28(\mathrm{~m}, 4 \mathrm{H})$, $1.03(\mathrm{t}, J=7.5 \mathrm{~Hz}, 3 \mathrm{H})$, and $0.91(\mathrm{t}, J=7.2 \mathrm{~Hz}, 3 \mathrm{H})$.

${ }^{13}$ C NMR (151 MHz, $\left.\mathbf{C D C l}_{3}\right): \delta 171.6,169.3,44.9,31.7,29.3,25.8,25.6,22.6,14.0$, and 11.7.

HRMS (ESI-TOF): calc'd for $\mathrm{C}_{12} \mathrm{H}_{20} \mathrm{NO}_{4}[\mathrm{M}+\mathrm{H}]^{+} 242.1387$; found 242.1378.<smiles>CCC(Br)C(=O)ON1C(=O)c2c(Cl)c(Cl)c(Cl)c(Cl)c2C1=O</smiles>

\section{4,5,6,7-Tetrachloro-1,3-dioxoisoindolin-2-yl 2-ethylhexanoate}

Following the General Procedure A with 2-ethylhexanoic acid (800 $\mu \mathrm{L}, 5.0 \mathrm{mmol})$, tetrachloro- $N$-hydroxyphthalimide $(1.5 \mathrm{~g}, 5.0 \mathrm{mmol})$ in $10.0 \mathrm{~mL}$ of $\mathrm{CH}_{2} \mathrm{Cl}_{2}$ at $\mathrm{rt}$ for 2 $\mathrm{h}$, afforded $1.3 \mathrm{~g}(61 \%)$ of the title compound after purification by column chromatography (gradient elution, hexanes to 4:1 hexanes:EtOAc). If desired, the title compound can be further purified by recrystallization with a small amount of $\mathrm{CH}_{2} \mathrm{Cl}_{2}$ in $\mathrm{MeOH}$.

Physical State: white solid, mp: $91-94^{\circ} \mathrm{C}$.

$\boldsymbol{R}_{\boldsymbol{f}}=0.76$ (4:1 hexanes:EtOAc). 
${ }^{1} \mathbf{H}$ NMR (600 MHz, $\left.\mathbf{C D C l}_{3}\right): \delta 2.65(\mathrm{tt}, J=9.1,5.2 \mathrm{~Hz}, 1 \mathrm{H}), 1.87-1.58(\mathrm{~m}, 4 \mathrm{H})$, $1.52-1.29(\mathrm{~m}, 4 \mathrm{H}), 1.07(\mathrm{t}, J=7.5 \mathrm{~Hz}, 3 \mathrm{H})$, and $0.94(\mathrm{t}, J=7.1 \mathrm{~Hz}, 3 \mathrm{H})$.

${ }^{13}$ C NMR (151 MHz, $\left.\mathbf{C D C l}_{3}\right): \delta 172.1,157.8,141.1,130.6,124.9,45.0,31.9,29.3$, 25.9, 22.6, 14.0, and 11.8.

HRMS (ESI-TOF): calc'd for $\mathrm{C}_{16} \mathrm{H}_{16} \mathrm{Cl}_{4} \mathrm{NO}_{4}[\mathrm{M}+\mathrm{H}]^{+} 425.9828$; found 425.9829 .<smiles>CCC(Br)C(=O)ON1C(=O)c2ccccc2C1=O</smiles>

\section{1,3-Dioxoisoindolin-2-yl 2-ethylhexanoate}

Following the General Procedure A with 2-ethylhexanoic acid (800 $\mu \mathrm{L}, 5.0 \mathrm{mmol})$ and $N$-hydroxyphthalimide $(815 \mathrm{mg}, 5.0 \mathrm{mmol})$ in $\mathrm{CH}_{2} \mathrm{Cl}_{2}(25.0 \mathrm{~mL})$ at $\mathrm{rt}$ for $2 \mathrm{~h}$ afforded $1.18 \mathrm{~g}(82 \%)$ of the title compound after purification by column chromatography (gradient elution, hexanes to 4:1 hexanes:EtOAc).

Physical State: colorless to slightly yellow oil.

$\boldsymbol{R}_{\boldsymbol{f}}=0.24$ (9:1 hexanes:EtOAc).

${ }^{1}$ H NMR (400 MHz, CDCl 3$): \delta 7.90(\mathrm{dd}, J=5.5,3.1 \mathrm{~Hz}, 2 \mathrm{H}), 7.80(\mathrm{dd}, J=5.5,3.1$ $\mathrm{Hz}, 2 \mathrm{H}), 2.68(\mathrm{tt}, J=8.9,5.4 \mathrm{~Hz}, 1 \mathrm{H}), 1.95-1.29(\mathrm{~m}, 8 \mathrm{H}), 1.10(\mathrm{t}, J=7.4 \mathrm{~Hz}, 3 \mathrm{H})$, and $0.96(\mathrm{t}, J=7.1 \mathrm{~Hz}, 3 \mathrm{H})$.

${ }^{13}$ C NMR (151 MHz, $\left.\mathbf{C D C l}_{3}\right): \delta 172.6,162.2,134.8,129.2,124.0,45.0,31.9,29.4$, 25.8, 22.7, 14.0, and 11.7.

HRMS (ESI-TOF): calc'd for $\mathrm{C}_{16} \mathrm{H}_{20} \mathrm{NO}_{4}[\mathrm{M}+\mathrm{H}]^{+}$290.1387; found 290.1387.<smiles>O=C(ON1C(=O)c2ccccc2C1=O)C1CCC1</smiles>

\section{1,3-Dioxoisoindolin-2-yl cyclobutanecarboxylate}

Following the General Procedure A with cyclobutane carboxylic acid $(0.383 \mathrm{~mL}, 4.0$ mmol) and $N$-hydroxyphthalimide $(0.653 \mathrm{~g}, 4.0 \mathrm{mmol})$ in $\mathrm{CH}_{2} \mathrm{Cl}_{2}(20.0 \mathrm{~mL})$ at $\mathrm{rt}$. Purification by column chromatography (9:1 hexanes:EtOAc) afforded $745 \mathrm{mg}$ (76\%) of the title compound.

Physical State: white solid; mp: $58^{\circ} \mathrm{C}$.

$\boldsymbol{R}_{\boldsymbol{f}}=0.40$ (3:1 hexanes:EtOAc). 
${ }^{1}$ H NMR (600 MHz, $\left.\mathbf{C D C l}_{3}\right): \delta 7.91-7.86(\mathrm{~m}, 2 \mathrm{H}), 7.82-7.76(\mathrm{~m}, 2 \mathrm{H}), 3.56-3.46$ $(\mathrm{m}, 1 \mathrm{H}), 2.57-2.46(\mathrm{~m}, 2 \mathrm{H}), 2.46-2.36(\mathrm{~m}, 2 \mathrm{H})$, and $2.17-1.99(\mathrm{~m}, 2 \mathrm{H})$.

${ }^{13}$ C NMR (150 MHz, $\mathbf{C D C l}_{3}$ ): $\delta$ 171.6, 162.2, 134.9, 129.1, 124.1, 35.2, 25.5, and 18.9.

HRMS (ESI-TOF): calc'd for $\mathrm{C}_{13} \mathrm{H}_{12} \mathrm{NO}_{4}[\mathrm{M}+\mathrm{H}]^{+}$246.0761; found 246.0762.<smiles>O=C(ON1C(=O)c2ccccc2C1=O)C1CCCC1</smiles>

\section{1,3-Dioxoisoindolin-2-yl cyclopentanecarboxylate}

The title compound was prepared following the General Procedure A with cyclopentane carboxylic acid $(0.95 \mathrm{~mL}, 8.76 \mathrm{mmol})$ and $N$-hydroxyphthalimide $(1.43$ g, $8.76 \mathrm{mmol})$ in $\mathrm{CH}_{2} \mathrm{Cl}_{2}(40.0 \mathrm{~mL})$. The crude material was purified by column chromatography (9:1 hexanes:EtOAc) to yield the title compound $(1.83 \mathrm{~g}, 80 \%)$ as a white solid.

Physical State: white solid; mp: $58^{\circ} \mathrm{C}$.

$\boldsymbol{R}_{\boldsymbol{f}}=0.40$ (3:1 hexanes:EtOAc).

${ }^{1}$ H NMR (600 MHz, CDCl $): \delta 7.92-7.85$ (m, 2H), 7.83 - $7.76(\mathrm{~m}, 2 \mathrm{H}), 3.17-3.01$ $(\mathrm{m}, 1 \mathrm{H}), 2.15-1.99(\mathrm{~m}, 4 \mathrm{H}), 1.85-1.74(\mathrm{~m}, 2 \mathrm{H})$, and $1.74-1.61(\mathrm{~m}, 2 \mathrm{H})$.

${ }^{13}$ C NMR (150 MHz, $\left.\mathbf{C D C l}_{3}\right)$ : $\delta$ 173.0, 162.3, 134.8, 129.1, 124.1, 40.8, 30.4, and 26.1 .

HRMS (ESI-TOF): calc'd for $\mathrm{C}_{14} \mathrm{H}_{14} \mathrm{NO}_{4}[\mathrm{M}+\mathrm{H}]^{+} 260.0917$; found 260.0918 .<smiles>O=C(ON1C(=O)c2ccccc2C1=O)C1CCCCC1</smiles>

\section{1,3-Dioxoisoindolin-2-yl cyclohexanecarboxylate}

The title compound was prepared following the General Procedure A with cyclohexane carboxylic acid $(513 \mathrm{mg}, 4.0 \mathrm{mmol}), N$-hydroxyphthalimide $(0.653 \mathrm{~g}$, $4.0 \mathrm{mmol})$ in $\mathrm{CH}_{2} \mathrm{Cl}_{2}(20.0 \mathrm{~mL})$. The crude material was purified by flash column chromatography (9:1 hexanes:EtOAc) to yield the title compound (863 mg, 79\%) as a white solid.

Physical State: white solid; $\mathrm{mp}: 66{ }^{\circ} \mathrm{C}$.

$\boldsymbol{R}_{\boldsymbol{f}}=0.40$ (3:1 hexanes:EtOAc). 
${ }^{1}$ H NMR (600 MHz, $\left.\mathbf{C D C l}_{3}\right): \delta 7.92-7.83(\mathrm{~m}, 2 \mathrm{H}), 7.82-7.74(\mathrm{~m}, 2 \mathrm{H}), 2.79-2.66$ $(\mathrm{m}, 1 \mathrm{H}), 2.15-2.02(\mathrm{~m}, 2 \mathrm{H}), 1.89-1.77(\mathrm{~m}, 2 \mathrm{H}), 1.76-1.55(\mathrm{~m}, 3 \mathrm{H})$, and $1.44-$ $1.22(\mathrm{~m}, 3 \mathrm{H})$.

${ }^{13}$ C NMR (151 MHz, $\left.\mathbf{C D C l}_{3}\right): \delta$ 172.0, 162.2, 134.8, 129.1, 124.0, 40.6, 28.9, 25.6, and 25.2 .

HRMS (ESI-TOF): calc'd for $\mathrm{C}_{15} \mathrm{H}_{16} \mathrm{NO}_{4}[\mathrm{M}+\mathrm{H}]^{+}$274.1074; found 274.1074.

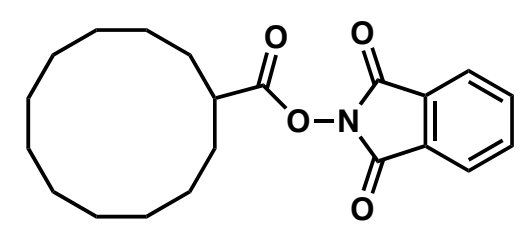

\section{1,3-Dioxoisoindolin-2-yl cyclododecanecarboxylate}

The title compound was prepared following the General Procedure A with cyclododecane carboxylic acid $(65 \mathrm{mg}, 0.31 \mathrm{mmol})$. The crude material was purified by column chromatography (9:1 hexanes:EtOAc) to yield the title compound (74 mg, $68 \%$ ) as a white solid.

Physical State: white solid; mp: $145^{\circ} \mathrm{C}$.

$\boldsymbol{R}_{\boldsymbol{f}}=0.48$ (3:1 hexanes:EtOAc).

${ }^{1}$ H NMR (600 MHz, $\left.\mathbf{C D C l}_{3}\right): \delta 7.91-7.82(\mathrm{~m}, 2 \mathrm{H}), 7.81-7.74(\mathrm{~m}, 2 \mathrm{H}), 2.93-2.84$ $(\mathrm{m}, 1 \mathrm{H}), 1.88-1.72(\mathrm{~m}, 4 \mathrm{H}), 1.61-1.52(\mathrm{~m}, 2 \mathrm{H})$, and $1.52-1.27(\mathrm{~m}, 16 \mathrm{H})$.

${ }^{13}$ C NMR (151 MHz, $\left.\mathbf{C D C l}_{3}\right): \delta 172.9,162.3,134.8,129.1,124.0,38.3,26.7,23.9$, 23.8, 23.6, 23.5, and 22.2.

HRMS (ESI-TOF): calc'd for $\mathrm{C}_{21} \mathrm{H}_{28} \mathrm{NO}_{4}[\mathrm{M}+\mathrm{H}]^{+}$358.2013; found 358.2015.<smiles>CC1(C)C(C(=O)ON2C(=O)c3c(Cl)c(Cl)c(Cl)c(Cl)c3C2=O)C1(C)C</smiles>

Tetrachloro-1,3-dioxoisoindolin-2-yl 2,2,3,3-tetramethylcyclopropanecarboxylate

The title compound was prepared following the General Procedure A with 2,2,3,3tetramethylcyclopropane carboxylic acid (500 $\mathrm{mg}, 3.52 \mathrm{mmol})$ and tetrachloro- $N$ hydroxyphthalimide to afford the title compound in $659 \mathrm{mg}(44 \%)$ after purification by column chromatography (9:1 hexanes:EtOAc) followed by recrystallization from $\mathrm{CH}_{2} \mathrm{Cl}_{2}$ and $\mathrm{MeOH}$ at $0{ }^{\circ} \mathrm{C}$. 
Physical State: white solid; mp: $135^{\circ} \mathrm{C}$.

$\boldsymbol{R}_{\boldsymbol{f}}=0.64$ (3:1 hexanes:EtOAc).

${ }^{1}$ H NMR (600 MHz, CDCl $): \delta 1.52(\mathrm{~s}, 1 \mathrm{H}), 1.31(\mathrm{~s}, 6 \mathrm{H})$, and $1.27(\mathrm{~s}, 6 \mathrm{H})$.

${ }^{13}$ C NMR (150 MHz, $\left.\mathbf{C D C l}_{3}\right): \delta 167.3,158.2,140.9,130.5,125.0,33.9,32.3,23.4$, and 16.6.

HRMS (ESI-TOF): calc'd for $\mathrm{C}_{16} \mathrm{H}_{13} \mathrm{Cl}_{4} \mathrm{NO}_{4}[\mathrm{M}+\mathrm{H}]^{+}$423.9677; found 423.9677 .<smiles>O=C(ON1C(=O)c2ccccc2C1=O)C1Cc2ccccc2C1</smiles>

\section{1,3-Dioxoisoindolin-2-yl 2,3-dihydro-1H-indene-2-carboxylate}

Following the General Procedure A with 2,3-dihydro- $1 H$-indene-2-carboxylic acid (162 mg, $1.0 \mathrm{mmol}$ ) and $N$-hydroxyphthalimide (163 mg, $1.0 \mathrm{mmol})$ in $\mathrm{CH}_{2} \mathrm{Cl}_{2}(10.0$ $\mathrm{mL})$ at $\mathrm{rt}$ for $2 \mathrm{~h}$, afforded $261 \mathrm{mg}(85 \%)$ of the title compound.

Physical State: white solid; mp: $165-167^{\circ} \mathrm{C}$.

$\boldsymbol{R}_{\boldsymbol{f}}=0.29$ (4:1 hexanes:EtOAc).

${ }^{1}$ H NMR (400 MHz, $\left.\mathbf{C D C l}_{3}\right): \delta 7.92(\mathrm{dd}, J=5.5,3.1 \mathrm{~Hz}, 2 \mathrm{H}), 7.81(\mathrm{dd}, J=5.5,3.1$ $\mathrm{Hz}, 2 \mathrm{H}), 7.30-7.26(\mathrm{~m}, 3 \mathrm{H}), 7.23-7.10(\mathrm{~m}, 2 \mathrm{H}), 3.80-3.65(\mathrm{~m}, 1 \mathrm{H}), 3.56-3.31$ (m, 4H).

${ }^{13}$ C NMR (101 MHz, $\left.\mathbf{C D C l}_{3}\right): \delta 171.6,162.0,140.6,134.8,129.0,127.0,124.4$, 124.0, 40.5, and 36.3.

HRMS (ESI-TOF): calc'd for $\mathrm{C}_{18} \mathrm{H}_{14} \mathrm{NO}_{4}[\mathrm{M}+\mathrm{H}]^{+}$308.0917; found 308.0919.<smiles>O=C(ON1C(=O)c2ccccc2C1=O)C1CC2CCC1CC2</smiles>

\section{1,3-Dioxoisoindolin-2-yl bicyclo[2.2.2]octane-2-carboxylate}

Following the General Procedure A with bicyclo[2.2.2] octane-2-carboxylic acid (90 $\mathrm{mg}, 0.58 \mathrm{mmol})$ and $\mathrm{N}$-hydroxyphthalimide $(95 \mathrm{mg}, 0.58 \mathrm{mmol})$ in $\mathrm{CH}_{2} \mathrm{Cl}_{2}(5.0 \mathrm{~mL})$ at $\mathrm{rt}$ for $2 \mathrm{~h}$ afforded $145 \mathrm{mg}(84 \%)$ of the title compound after purification by column chromatography (4:1 hexanes:EtOAc).

Physical State: white solid; mp: $111-113{ }^{\circ} \mathrm{C}$. 
$\boldsymbol{R}_{\boldsymbol{f}}=0.41$ (4:1 hexanes:EtOAc).

${ }^{1}$ H NMR (400 MHz, CDCl 3$): \delta 7.89(\mathrm{dd}, J=5.4,3.1 \mathrm{~Hz}, 2 \mathrm{H}), 7.80(\mathrm{dd}, J=5.4,3.2$ $\mathrm{Hz}, 2 \mathrm{H}), 3.15-2.87(\mathrm{~m}, 1 \mathrm{H}), 2.21(\mathrm{t}, J=2.9 \mathrm{~Hz}, 1 \mathrm{H}), 2.14-2.00(\mathrm{~m}, 1 \mathrm{H}), 1.92-$ $1.79(\mathrm{~m}, 2 \mathrm{H})$, and $1.76-1.42(\mathrm{~m}, 8 \mathrm{H})$.

${ }^{13}$ C NMR (101 MHz, $\left.\mathbf{C D C l}_{3}\right): \delta 172.4,162.2,134.7,129.0,123.9,39.5,28.2,27.8$, $26.0,24.9,24.8,23.4$, and 21.4.

HRMS (ESI-TOF): calc'd for $\mathrm{C}_{17} \mathrm{H}_{18} \mathrm{NO}_{4}[\mathrm{M}+\mathrm{H}]^{+}$300.1230; found 300.1232.<smiles>O=C(ON1C(=O)c2ccccc2C1=O)C1C2CC3CC(C2)CC1C3</smiles>

\section{1,3-Dioxoisoindolin-2-adamantane-2-carboxylate}

Following the General Procedure A with 2-adamantane carboxylic acid (180 mg, 1.0 mmol) and $N$-hydroxyphthalimide $(163 \mathrm{mg}, 1.0 \mathrm{mmol})$ in $\mathrm{CH}_{2} \mathrm{Cl}_{2}(10.0 \mathrm{~mL})$ at $\mathrm{rt}$ for 2 $\mathrm{h}$ afforded $244 \mathrm{mg}(75 \%)$ of the title compound after purification by column chromatography (4:1 hexanes:EtOAc).

Physical State: white solid; mp: $143-145^{\circ} \mathrm{C}$.

$\boldsymbol{R}_{\boldsymbol{f}}=0.40$ (4:1 hexanes:EtOAc).

${ }^{1}$ H NMR (600 MHz, $\left.\mathbf{C D C l}_{3}\right): \delta 7.91(\mathrm{dd}, J=5.5,3.1 \mathrm{~Hz}, 2 \mathrm{H}), 7.81(\mathrm{dd}, J=5.5,3.1$ $\mathrm{Hz}, 2 \mathrm{H}), 3.11(\mathrm{t}, J=2.1 \mathrm{~Hz}, 1 \mathrm{H}), 2.52(\mathrm{q}, J=3.0 \mathrm{~Hz}, 2 \mathrm{H}), 2.13(\mathrm{dd}, J=13.3,3.0 \mathrm{~Hz}$, 2H), $2.03-1.91(\mathrm{~m}, 4 \mathrm{H}), 1.87(\mathrm{dd}, J=12.4,2.8 \mathrm{~Hz}, 2 \mathrm{H}), 1.81(\mathrm{ddd}, J=4.3,2.7,1.5$ $\mathrm{Hz}, 2 \mathrm{H}$ ), and 1.75 (ddd, $J=13.3,3.2,1.7 \mathrm{~Hz}, 2 \mathrm{H})$.

${ }^{13}$ C NMR (151 MHz, $\left.\mathbf{C D C l}_{3}\right)$ : $\delta$ 170.0, 161.8, 134.2, 128.6, 123.4, 47.0, 37.4, 36.7, $32.7,29.3,26.8$, and 26.7 .

HRMS (ESI-TOF): calc'd for $\mathrm{C}_{19} \mathrm{H}_{20} \mathrm{NO}_{4}[\mathrm{M}+\mathrm{H}]^{+}$326.1387; found 326.1385.<smiles>CC(C)C(=O)ON1C(=O)c2ccccc2C1=O</smiles>

\section{1,3-Dioxoisoindolin-2-yl isobutyrate}

Following the General Procedure A with 2-ethylhexanoic acid $(0.908 \mathrm{~mL}, 10.0 \mathrm{mmol}$, 1.0 equiv), $N$-hydroxyphthalimide ( $1.63 \mathrm{~g}, 10.0 \mathrm{mmol}, 1.0$ equiv.) in $\mathrm{CH}_{2} \mathrm{Cl}_{2}$ (25.0 
$\mathrm{mL})$ at $\mathrm{rt}$ for $12 \mathrm{~h}$ afforded $1.83 \mathrm{~g}(7.8 \mathrm{mmol}, 78 \%)$ of the title compound after purification by column chromatography (gradient elution, hexanes to 9:1 hexanes:EtOAc).

Physical State: white solid; mp: $49-53{ }^{\circ} \mathrm{C}$.

$\boldsymbol{R}_{\boldsymbol{f}}=0.40$ (4:1 hexanes:EtOAc).

${ }^{1}$ H NMR (600 MHz, CDCl $)$ ): $\delta 7.91-7.86(\mathrm{~m}, 2 \mathrm{H}), 7.81-7.76(\mathrm{~m}, 2 \mathrm{H}), 2.96$ (hept, $J=7.0 \mathrm{~Hz}, 1 \mathrm{H})$, and $1.38(\mathrm{~d}, J=7.0 \mathrm{~Hz}, 6 \mathrm{H})$.

${ }^{13}$ C NMR (151 MHz, $\left.\mathbf{C D C l}_{3}\right): \delta$ 173.2, 162.2, 134.8, 129.2, 124.1, 31.9, and 19.0.

HRMS (ESI-TOF): calc'd for $\mathrm{C}_{12} \mathrm{H}_{12} \mathrm{NO}_{4}[\mathrm{M}+\mathrm{H}]^{+}$234.0761; found 234.0762.<smiles>O=C(ON1C(=O)c2ccccc2C1=O)C1CCCO1</smiles>

\section{1,3-Dioxoisoindolin-2-yl tetrahydrofuran-2-carboxylate}

Following the General Procedure A with tetrahydrofuran-2-carboxylic acid (480 $\mu \mathrm{L}$, $5.0 \mathrm{mmol}$ ) and $\mathrm{N}$-hydroxyphthalimide $(816 \mathrm{mg}, 5.0 \mathrm{mmol})$ in $\mathrm{CH}_{2} \mathrm{Cl}_{2}(20.0 \mathrm{~mL})$ at $\mathrm{rt}$ for $0.5 \mathrm{~h}$ afforded $1.12 \mathrm{~g}(82 \%)$ of the title compound after purification by column chromatography (2:1 hexanes:EtOAc).

Physical State: white solid; $\mathrm{mp}=44-45^{\circ} \mathrm{C}$.

$\boldsymbol{R}_{\boldsymbol{f}}=0.40$ (2:1 hexanes:EtOAc).

${ }^{1}$ H NMR (600 MHz, $\left.\mathbf{C D C l}_{3}\right): \delta 7.89(\mathrm{dd}, J=5.5,3.1 \mathrm{~Hz}, 2 \mathrm{H}), 7.80(\mathrm{dd}, J=5.5,3.1$ $\mathrm{Hz}, 2 \mathrm{H}), 4.87$ (dd, $J=8.6,4.9 \mathrm{~Hz}, 1 \mathrm{H}), 4.14-4.06$ (m, 1H), 4.04-3.98 (m, 1H), 2.49$2.35(\mathrm{~m}, 2 \mathrm{H})$, and 2.15-1.98 (m, 2H).

${ }^{13}$ C NMR (151 MHz, $\left.\mathbf{C D C l}_{3}\right): \delta 169.9,161.9,135.0,129.0,124.2,75.1,70.0,31.0$, and 25.2.

HRMS (ESI-TOF): calc'd for $\mathrm{C}_{13} \mathrm{H}_{12} \mathrm{NO}_{5}{ }^{+}[\mathrm{M}+\mathrm{H}]^{+}$262.0710; found 262.0709.<smiles>O=C(OC(=O)N1CC(C(=O)ON2C(=O)c3c(Cl)c(Cl)c(Cl)c(Cl)c3C2=O)C1)c1ccccc1</smiles>

1-(tert-Butyl) 3-(4,5,6,7-tetrachloro-1,3-dioxoisoindolin-2-yl) azetidine-1,3dicarboxylate 
Following the General Procedure A with $N$-Boc-2-azetidine acid (500 mg, $2.5 \mathrm{mmol}$ ) and tetrachloro- $N$-hydroxyphthalimide $(750 \mathrm{mg}, 2.5 \mathrm{mmol})$ in $\mathrm{CH}_{2} \mathrm{Cl}_{2}(20.0 \mathrm{~mL})$ at $\mathrm{rt}$ for $2 \mathrm{~h}$ afforded $709 \mathrm{mg}$ (59\%) of the title compound following purification by column chromatography $\left(10: 1 \quad \mathrm{CH}_{2} \mathrm{Cl}_{2}: \mathrm{Et}_{2} \mathrm{O}\right)$ followed by recrystallization from a small amount of $\mathrm{CH}_{2} \mathrm{Cl}_{2}$ with $\mathrm{MeOH}$.

Physical State: white solid; mp: $148-149^{\circ} \mathrm{C}$.

$\boldsymbol{R}_{\boldsymbol{f}}=0.66$ (2:1 hexanes:EtOAc).

${ }^{1}$ H NMR (600 MHz, $\left.\mathbf{C D C l}_{3}\right): \delta 4.27(\mathrm{~d}, J=7.4 \mathrm{~Hz}, 4 \mathrm{H}), 3.71(\mathrm{p}, J=7.5 \mathrm{~Hz}, 1 \mathrm{H})$, and $1.45(\mathrm{~s}, 9 \mathrm{H})$.

${ }^{13}$ C NMR (151 MHz, CDCl 3$): \delta 168.8,157.5,155.8,141.4,130.8,124.7,80.5,51.6$, 29.7, and 28.5.

HRMS (ESI-TOF): calc'd for $\mathrm{C}_{17} \mathrm{H}_{15} \mathrm{Cl}_{4} \mathrm{~N}_{2} \mathrm{O}_{6}[\mathrm{M}+\mathrm{H}]^{+} 482.9679$; found 482.9679 .<smiles>CC(C)(C)OC(=O)N1CCC(C(=O)ON2C(=O)c3c(Cl)c(Cl)c(Cl)c(Cl)c3C2=O)CC1</smiles>

1-(tert-Butyl) 4-(4,5,6,7-tetrachloro-1,3-dioxoisoindolin-2-yl) piperidine-1,4dicarboxylate

Following the General Procedure A with 1-(tert-butoxycarbonyl)piperidine-4carboxylic acid (1.15 g, $5.0 \mathrm{mmol})$ and tetrachloro- $N$-hydroxyphthalimide (1.50 g, 5.0 mmol) in $\mathrm{CH}_{2} \mathrm{Cl}_{2}(25.0 \mathrm{~mL})$ at $\mathrm{rt}$ for $2 \mathrm{~h}$ afforded $1.86 \mathrm{~g}(73 \%)$ of the title compound after purification by column chromatography (3:1 hexanes:EtOAc).

Physical State: white solid; mp: $190-192^{\circ} \mathrm{C}$.

$\boldsymbol{R}_{\boldsymbol{f}}=0.55$ (3:1 hexanes:EtOAc).

${ }^{1}$ H NMR (600 MHz, CDCl$\left.)_{3}\right): \delta 4.00$ (br s, 2H), 3.00 (t, $\left.J=11.2 \mathrm{~Hz}, 2 \mathrm{H}\right), 2.90$ (tt, $J=$ $10.3,4.0 \mathrm{~Hz}, 1 \mathrm{H}), 2.05-2.01(\mathrm{~m}, 2 \mathrm{H}), 1.85-1.79(\mathrm{~m}, 2 \mathrm{H})$, and $1.44(\mathrm{~s}, 9 \mathrm{H})$.

${ }^{13}$ C NMR (151 MHz, $\left.\mathbf{C D C l}_{3}\right): \delta 170.3,157.6,154.6,141.1,130.6,124.8,80.0,42.6$ (br), 38.5, 28.5, and 27.8.

HRMS (ESI-TOF): calc'd for $\mathrm{C}_{19} \mathrm{H}_{19} \mathrm{Cl}_{4} \mathrm{~N}_{2} \mathrm{O}_{6}[\mathrm{M}+\mathrm{H}]^{+}$510.9992; found 510.9993. 
<smiles>O=C(ON1C(=O)c2ccccc2C1=O)C1CCC(F)(F)CC1</smiles>

\section{1,3-dioxoisoindolin-2-yl 4,4-difluorocyclohexane-1-carboxylate}

Following the General Procedure A with 4,4-difluorocyclohexane-1-carboxylic acid (0.164 g, $1.0 \mathrm{mmol})$ and $\mathrm{N}$-hydroxyphthalimide $(0.163 \mathrm{~g}, 1.0 \mathrm{mmol})$ in $\mathrm{CH}_{2} \mathrm{Cl}_{2}(10.0$ $\mathrm{mL})$ at $\mathrm{rt}$ for $12 \mathrm{~h}$ afforded $223 \mathrm{mg}(72 \%)$ of the title compound after purification by column chromatography (gradient elution, hexanes to 4:1 hexanes/EtOAc).

Physical State: white solid; mp: $109-111^{\circ} \mathrm{C}$.

$\boldsymbol{R}_{\boldsymbol{f}}=0.32$ (4:1 hexanes/EtOAc).

${ }^{1}$ H NMR (600 MHz, $\left.\mathbf{C D C l}_{3}\right): \delta 7.91-7.87$ (m, 2H), $7.82-7.78$ (m, 2H), 2.88 (ddt, $J$ $=8.7,7.4,2.4 \mathrm{~Hz}, 1 \mathrm{H}), 2.25-2.14(\mathrm{~m}, 4 \mathrm{H}), 2.13-2.06(\mathrm{~m}, 2 \mathrm{H})$, and $1.98-1.84(\mathrm{~m}$, $2 \mathrm{H})$.

${ }^{13}$ C NMR (151 MHz, CDCl 3 ) $\delta$ 170.6, 162.0, 135.0, 129.1, 124.2, 122.3 (t, $J=242.3$ $\mathrm{Hz}), 38.0,32.2(\mathrm{t}, J=24.8 \mathrm{~Hz})$, and $25.1(\mathrm{t}, J=5.0 \mathrm{~Hz})$.

${ }^{19}$ F NMR (376 MHz, CDCl$)$ ): $\delta-96.01(\mathrm{~d}, J=240.2 \mathrm{~Hz}),-98.80(\mathrm{~d}, J=240.3 \mathrm{~Hz})$.

HRMS (ESI-TOF): calc'd for $\mathrm{C}_{15} \mathrm{H}_{14} \mathrm{~F}_{2} \mathrm{NO}_{4}[\mathrm{M}+\mathrm{H}]^{+} 310.0885$; found 310.0886 .<smiles>CC(C)(C)OC(=O)N1CCC(C(=O)ON2C(=O)c3ccccc3C2=O)CC1</smiles>

1-(tert-Butyl) 4-(1,3-dioxoisoindolin-2-yl) piperidine-1,4-dicarboxylate

Following the General Procedure A with 1-(tert-butoxycarbonyl)piperidine-4carboxylic acid (229 mg, $1.0 \mathrm{mmol})$ and $N$-hydroxyphthalimide (163 mg, $1.0 \mathrm{mmol}$ ) in $5 \mathrm{~mL}$ of $\mathrm{CH}_{2} \mathrm{Cl}_{2}$ at $\mathrm{rt}$ for $2 \mathrm{~h}$, afforded $242 \mathrm{mg}(65 \%)$ of the title compound after purification by column chromatography (3:1 hexanes:EtOAc).

Physical State: white solid; mp: $102-105^{\circ} \mathrm{C}$.

$\boldsymbol{R}_{\boldsymbol{f}}=0.30$ (3:1 hexanes:EtOAc).

${ }^{1}$ H NMR (400 MHz, CDCl $)$ ): $\delta$ 7.90-7.87 (m, 2H), 7.81-7.79 (m, 2H), 4.04 (br s, 2H), 3.01 (br s, 2H), $2.91(\mathrm{tt}, J=10.4,4.0 \mathrm{~Hz}, 1 \mathrm{H}), 2.08-2.04(\mathrm{~m}, 2 \mathrm{H}), 1.88-1.82(\mathrm{~m}, 2 \mathrm{H})$, and $1.46(\mathrm{~s}, 9 \mathrm{H})$.

${ }^{13}$ C NMR (101 MHz, $\left.\mathbf{C D C l}_{3}\right): \delta 170.8,162.1,154.7,134.9,129.0,124.1,80.0,42.7$

(br), 38.7, 28.6, and 27.9. 
HRMS (ESI-TOF): calc'd for $\mathrm{C}_{19} \mathrm{H}_{23} \mathrm{~N}_{2} \mathrm{O}_{6}[\mathrm{M}+\mathrm{H}]^{+} 375.1551$; found 375.1554 .<smiles>O=C(ON1C(=O)c2ccccc2C1=O)C1CCOCC1</smiles>

\section{1,3-dioxoisoindolin-2-yl tetrahydro-2H-pyran-4-carboxylate}

Following the General Procedure A with tetrahydro-2H-pyran-4-carboxylic acid (260 $\mathrm{mg}, 2.0 \mathrm{mmol}$ ), and $N$-hydroxyphthalimide (391 mg, $2.4 \mathrm{mmol})$ in $\mathrm{CH}_{2} \mathrm{Cl}_{2}(20.0 \mathrm{~mL}$ ) at $\mathrm{rt}$ for $0.5 \mathrm{~h}$ to afford $471 \mathrm{mg}(85 \%)$ of the title compound following purification by column chromatography (2:1 hexanes:EtOAc).

Physical State: white solid; $\mathrm{mp}=118-119^{\circ} \mathrm{C}$.

$\mathbf{R}_{\boldsymbol{f}}=0.43$ (2:1 hexanes:EtOAc).

${ }^{1}$ H NMR (600 MHz, $\left.\mathbf{C D C l}_{3}\right): \delta 7.89(\mathrm{dd}, J=5.5,3.1 \mathrm{~Hz}, 2 \mathrm{H}), 7.80(\mathrm{dd}, J=5.5,3.1$ Hz, 2H), $4.02(\mathrm{dt}, J=11.8,3.8 \mathrm{~Hz}, 2 \mathrm{H}), 3.53$ (ddd, $J=11.8,10.4,2.9 \mathrm{~Hz}, 2 \mathrm{H}), 3.10$ $2.93(\mathrm{~m}, 1 \mathrm{H})$, and 2.07-1.95 (m, 4H).

${ }^{13} \mathbf{C}$ NMR (151 MHz, $\left.\mathbf{C D C l}_{3}\right): \delta 170.7,162.1,135.0,129.1,124.1,66.7,37.8$, and 28.5 .

HRMS (ESI-TOF): calc'd for $\mathrm{C}_{14} \mathrm{H}_{14} \mathrm{NO}_{5}{ }^{+}[\mathrm{M}+\mathrm{H}]^{+}$276.0866; found 276.0868.<smiles>O=C(ON1C(=O)c2ccccc2C1=O)C1C2CC3C(C2=O)C31</smiles>

\section{1,3-dioxoisoindolin-2-yl 5-oxotricyclo[2.2.1.0 $0^{2,6}$ Jheptane-3-carboxylate}

Following the General Procedure A with 5-oxotricyclo[2.2.1.0 $0^{2,6}$ heptane-3carboxylic acid (152 mg, $1.0 \mathrm{mmol})$ and $N$-hydroxyphthalimide (163 mg, $1.0 \mathrm{mmol})$ in $\mathrm{CH}_{2} \mathrm{Cl}_{2}(10.0 \mathrm{~mL})$ at $\mathrm{rt}$ for $2 \mathrm{~h}$ afforded $244 \mathrm{mg}(82 \%)$ of the title compound 34 following purification by column chromatography (4:1 hexanes:EtOAc).

Physical State: white solid; mp: $128-130^{\circ} \mathrm{C}$.

$\boldsymbol{R}_{\boldsymbol{f}}=0.14$ (4:1 hexanes:EtOAc).

${ }^{1}$ H NMR (600 MHz, $\left.\mathbf{C D C l}_{3}\right): \delta 7.92(\mathrm{dd}, J=5.5,3.1 \mathrm{~Hz}, 2 \mathrm{H}), 7.83(\mathrm{dd}, J=5.5,3.1$ $\mathrm{Hz}, 2 \mathrm{H}), 3.43(\mathrm{dd}, J=1.8,1.2 \mathrm{~Hz}, 1 \mathrm{H}), 2.59(\mathrm{tt}, J=5.2,1.2 \mathrm{~Hz}, 1 \mathrm{H}), 2.50(\mathrm{dd}, J=$ 1.8, $1.0 \mathrm{~Hz}, 1 \mathrm{H}), 2.39$ (dddd, $J=6.4,4.1,1.8,1.2 \mathrm{~Hz}, 1 \mathrm{H}), 2.15$ (qt, $J=11.6,1.6 \mathrm{~Hz}$, $2 \mathrm{H}), 1.62(\mathrm{td}, J=5.4,0.8 \mathrm{~Hz}, 1 \mathrm{H})$. 
${ }^{13}$ C NMR (151 MHz, $\left.\mathbf{C D C l}_{3}\right): \delta 208.0,167.1,161.3,134.4,128.4,123.6,43.3,40.7$, 28.5, 20.6, 19.2, and 19.1.

HRMS (ESI-TOF): calc'd for $\mathrm{C}_{16} \mathrm{H}_{12} \mathrm{NO}_{5}[\mathrm{M}+\mathrm{H}]^{+}$298.0710; found 298.0711.<smiles>CC(COC(C)(C)C)C(=O)ON1C(=O)c2ccccc2C1=O</smiles>

\section{1,3-dioxoisoindolin-2-yl 3-((tert-butyldimethylsilyl)oxy)-2-methylpropanoate}

Following the General Procedure A with 3-((tert-butyldimethylsilyl)oxy)-2methylpropanoic $\operatorname{acid}^{4}(1.00 \mathrm{~g}, 4.6 \mathrm{mmol})$ and $N$-hydroxyphthalimide $(747 \mathrm{mg}, 4.6$ $\mathrm{mmol})$ in $\mathrm{CH}_{2} \mathrm{Cl}_{2}(15.0 \mathrm{~mL})$ at $\mathrm{rt}$ for $2 \mathrm{~h}$ afforded $1.00 \mathrm{~g}(60 \%)$ of the title compound following purification by column chromatography (gradient elution, 19:1 hexanes:EtOAc to 9:1 hexanes:EtOAc).

Physical State: clear oil.

$\boldsymbol{R}_{\boldsymbol{f}}=0.46$ (4:1 hexanes:EtOAc).

${ }^{1} \mathrm{H}$ NMR $\left(600 \mathrm{MHz}, \mathrm{CDCl}_{3}\right) \delta 7.88(\mathrm{dd}, J=5.5,3.1 \mathrm{~Hz}, 2 \mathrm{H}), 7.78(\mathrm{dd}, J=5.5,3.1$ $\mathrm{Hz}, 2 \mathrm{H}), 3.94(\mathrm{dd}, J=9.9,6.6 \mathrm{~Hz}, 1 \mathrm{H}), 3.80(\mathrm{dd}, J=9.8,6.1 \mathrm{~Hz}, 1 \mathrm{H}), 3.12-2.97$ (m, $1 \mathrm{H}), 1.36(\mathrm{~d}, J=7.1 \mathrm{~Hz}, 3 \mathrm{H}), 0.92(\mathrm{~s}, 9 \mathrm{H})$, and $0.10(\mathrm{~d}, J=1.0 \mathrm{~Hz}, 6 \mathrm{H}$, overlapping peaks).

${ }^{13} \mathrm{C} \mathrm{NMR}\left(151 \mathrm{MHz}, \mathrm{CDCl}_{3}\right) \delta 171.2,134.8,129.2,124.0,64.6,40.6,26.0,18.4$, 13.7, and $-5.4(2 \mathrm{C})$.

HRMS (ESI-TOF): calc'd for $\mathrm{C}_{18} \mathrm{H}_{26} \mathrm{NO}_{5} \mathrm{Si}[\mathrm{M}+\mathrm{H}]^{+}$364.1575; found 364.1576. 
Graphical Supporting Information for the Synthesis of NHPI and 4Cl-NHPI Esters
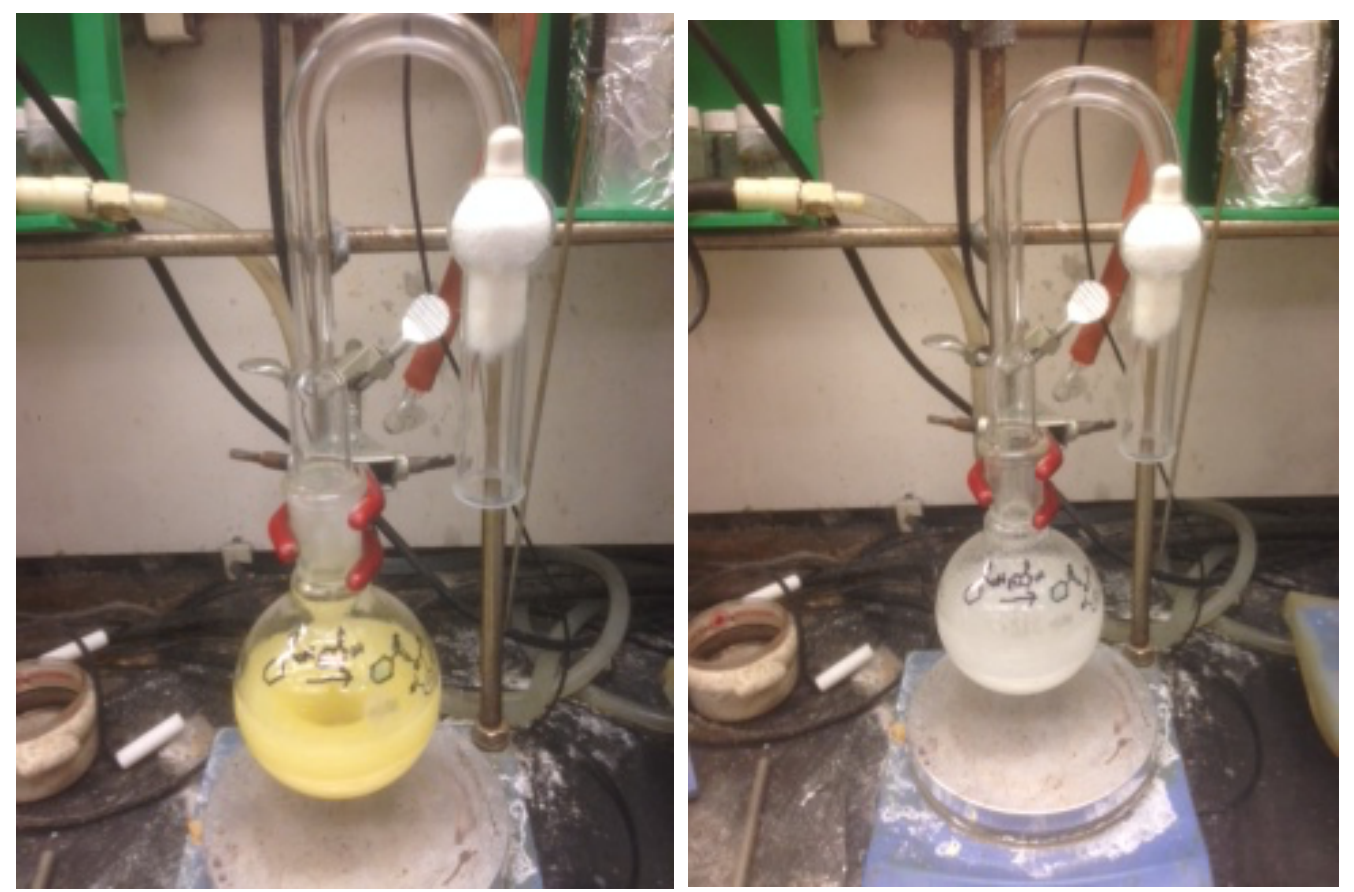

(Left) Reaction of N-hydroxyphthalamide with cyclohexane carboxylic acid in the presence of DIC at $\mathrm{t}$ $=0$ min. (Right) Reaction of $N$-hydroxyphthalamide with cyclohexane carboxylic acid in the presence of DIC at $\mathrm{t}=2 \mathrm{~h}$.

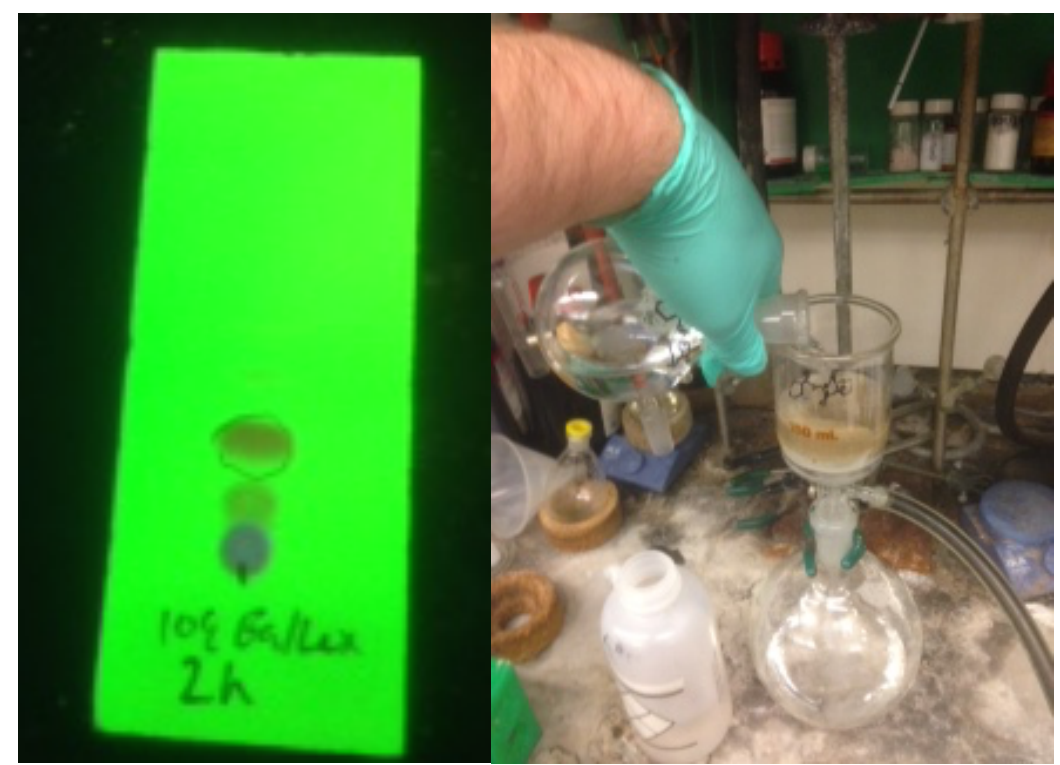

(Left) TLC of reaction mixture after 2 h (9:1 hexanes:EtOAc). (Right) The reaction was passed over a pad of silica (rinsed with EtOAc). 


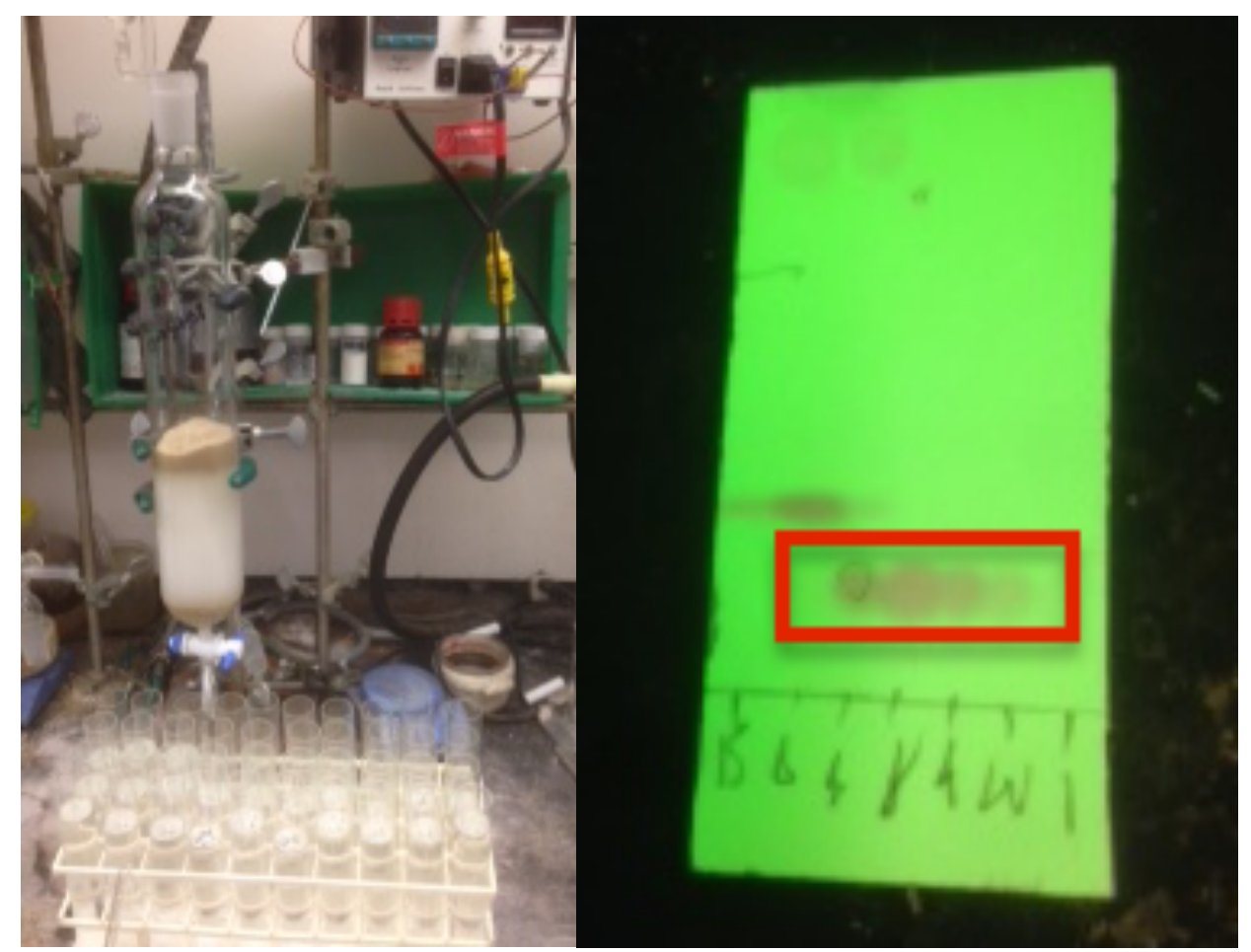

(Left) The crude organics were purified by silica gel chromatography (gradient elution, 95:5 hexanes:EtOAc to 9:1 hexanes:EtOAc). (Right) TLC of fractions from column chromatography; the fractions containing the product are indicated by the red box.

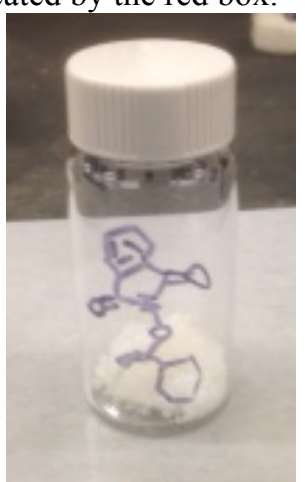

(Above) A pure sample of 1,3-dioxoisoindolin-2-yl cyclohexanecarboxylate (white solid).

General Procedure for the Preparation of Aryl Zinc reagents from Aryl Bromides

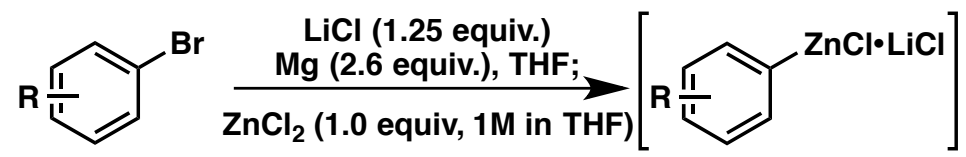

\section{Preparation of $\mathrm{ZnCl}_{2}$ Solution (1.0 M in THF)}

A Schlenk flask equipped with stir bar was flame-dried and allowed to cool to $\mathrm{rt}$ under vacuum. The flask was backfilled with nitrogen, and $\mathrm{ZnCl}_{2}(3.41 \mathrm{~g}, 25.0 \mathrm{mmol})$ was added. The flask was placed under vacuum and heated in an oil-bath preheated to $150{ }^{\circ} \mathrm{C}$. After stirring for $2-12 \mathrm{~h}$, the flask was removed from the oil bath and 
allowed to cool to rt. The flask was backfilled with nitrogen, and THF (anhydrous, 25 $\mathrm{mL}$ ) was added. The mixture was vigorously stirred until all $\mathrm{ZnCl}_{2}$ was dissolved (approximately $12 \mathrm{~h}$ ). However, if necessary the solution can be used before all solids have completely dissolved without a decrease in yield of the subsequent reaction.

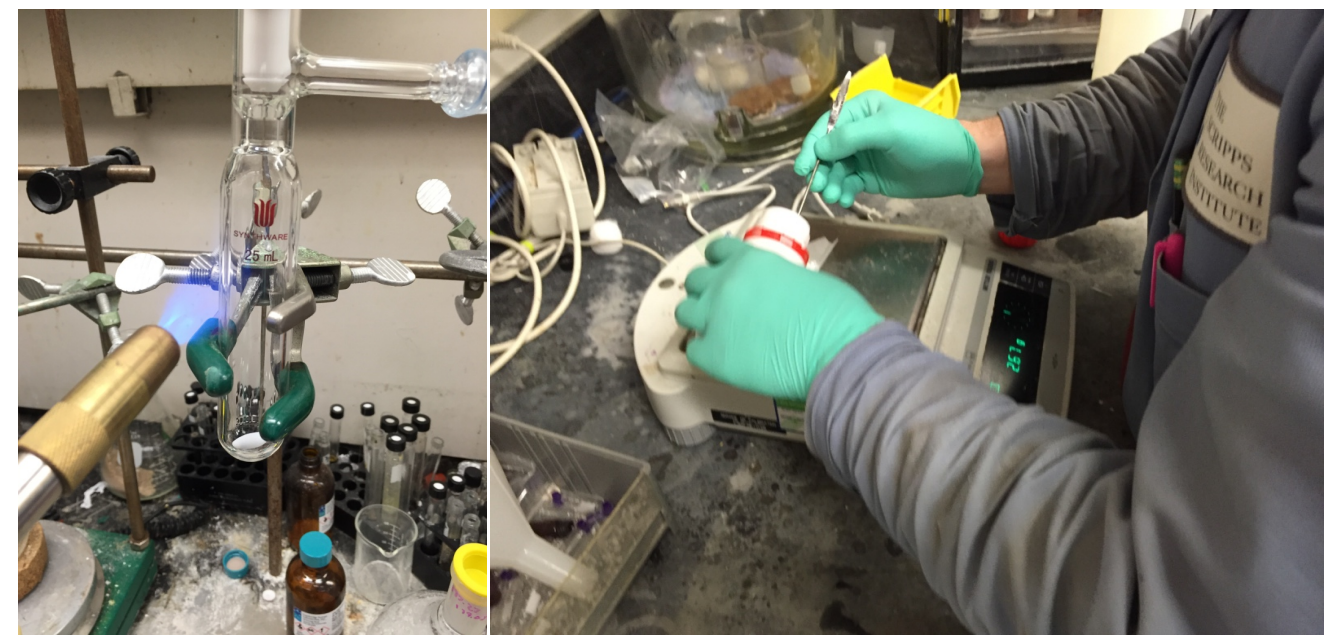

(Left) Flame-drying Schlenk flask under vacuum. The flask was backfilled with nitrogen upon cooling. (Right) Weighing $\mathrm{ZnCl}_{2}$ on the benchtop.

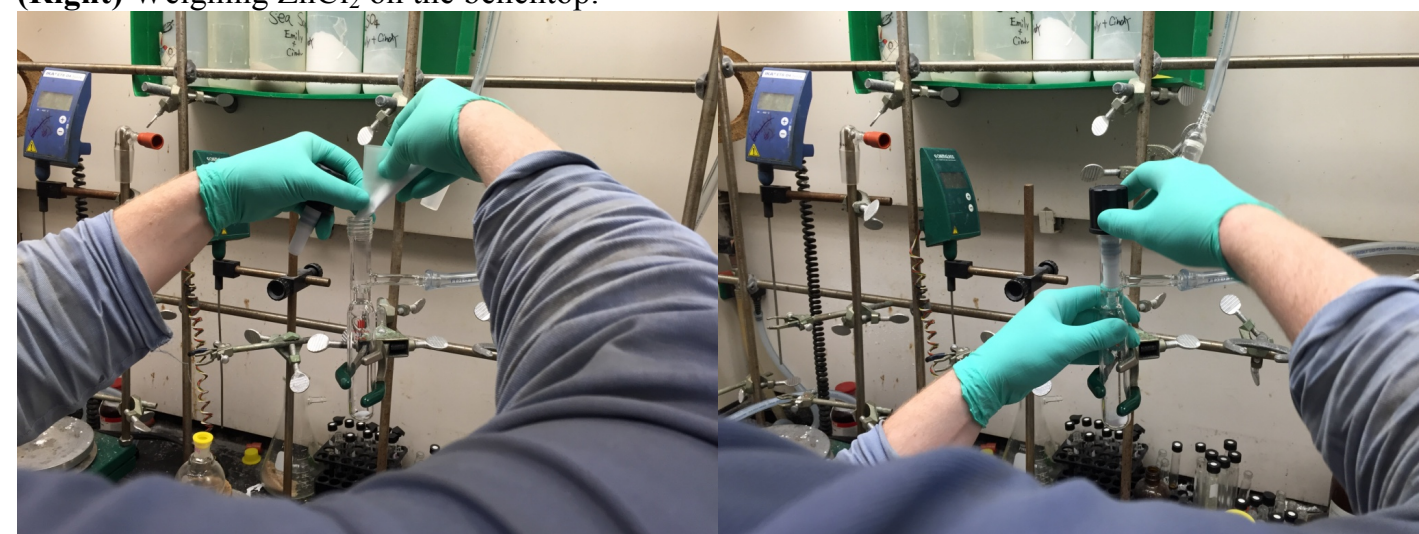

(Left) Addition of $\mathrm{ZnCl}_{2}$ to Schlenk flask under flow of nitrogen. (Right) Closing the Schlenk flask. 


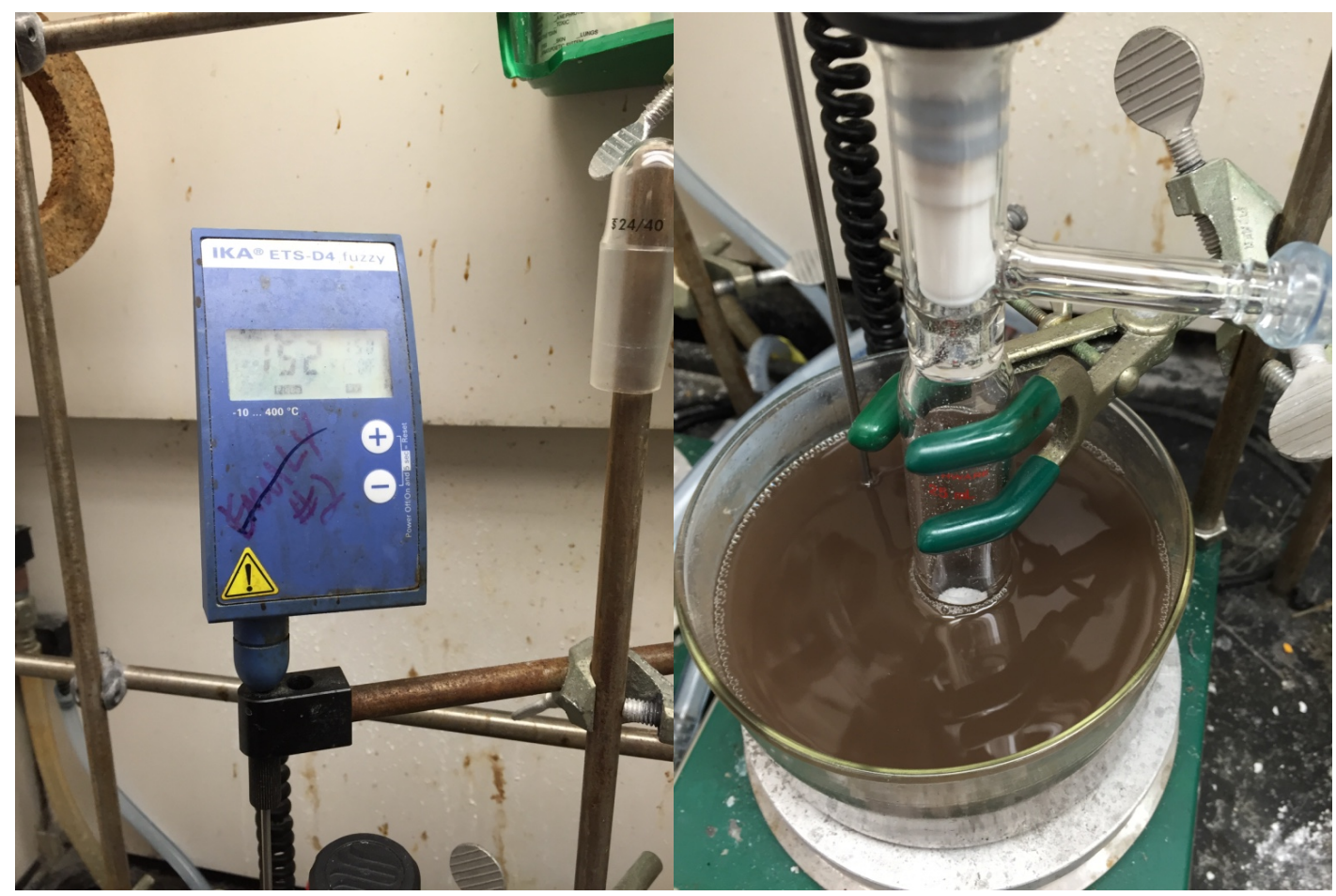

(Left) A preheated oil bath set to $150{ }^{\circ} \mathrm{C}$. Small temperature fluctuations do not affect the quality of the drying. (Right) Schlenk flask under vacuum is heated in oil bath with stirring for $3-12 \mathrm{~h}$.

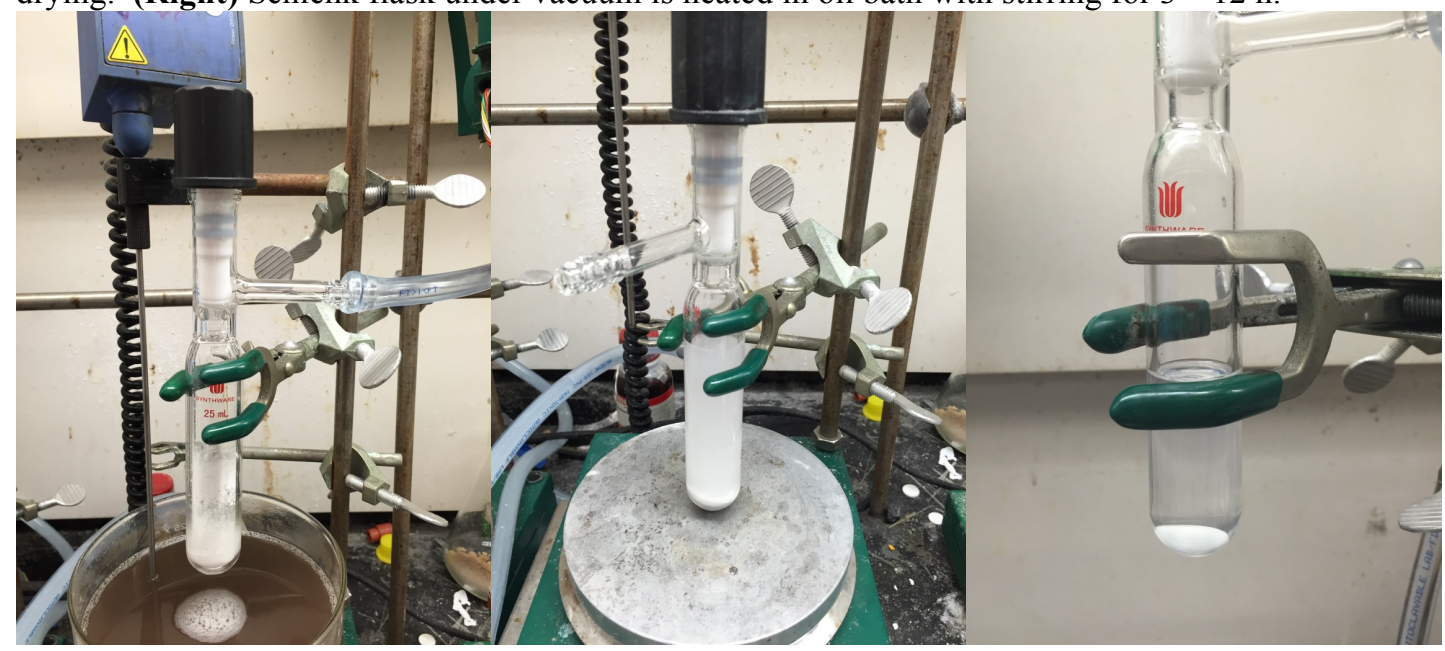

(Left) The Schlenk flask is removed from the oil bath and allowed to cool to rt. (Center) After 10 min of vigorous stirring. To fully dissolve all solids requires longer stirring times, but use of this solution at this stage in preparation of arylzinc does not result in subpar reaction performance. (Right) $\mathrm{ZnCl}_{2}(1 \mathrm{M}$ in THF) after $12 \mathrm{~h}$ of stirring.

\section{Arylzinc Reagent Preparation from Aryl Bromides}

Arylzinc reagents were prepared in a manner similar to that report by Knochel and coworkers. ${ }^{5} \mathrm{LiCl}(0.265 \mathrm{~g}, 6.25 \mathrm{mmol}, 1.25$ equiv.) was added to a round-bottom flask. The flask was placed under vacuum and flame-dried. Upon cooling the flask was backfilled with Ar from a balloon. Magnesium turnings (0.304 g, $12.5 \mathrm{mmol}, 2.5$ equiv.) were added by quickly removing the septum, adding the magnesium turnings, and replacing the septum. Tetrahydrofuran (anhydrous, $12.5 \mathrm{~mL}$ ) was added, and the mixture was stirred vigorously for $5 \mathrm{~min}$. DIBAL-H (1.0 M in THF, $0.05 \mathrm{~mL}, 0.01$ 
equiv) was added via syringe, and the mixture was stirred vigorously for $5 \mathrm{~min}$. The flask was then cooled to $0{ }^{\circ} \mathrm{C}$ in an ice/water bath, and aryl bromide (5.0 mmol, 1.0 equiv) was added via syringe if a liquid. If the aryl bromide was a solid, a septum was removed, the aryl bromide was quickly added, and the septum was replaced. After 10 minutes the ice/water bath was removed, and the mixture was stirred at $\mathrm{rt}$ until all aryl bromide was consumed (as determined by quenching an aliquot with water and observing the disappearance of the aryl bromide in the GC/MS spectrum; alternatively, an aliquot can be quenched into a solution of $I_{2}$ and conversion for aryl bromide to aryl iodide can be observed by $\mathrm{GC} / \mathrm{MS}) . \mathrm{ZnCl}_{2}$ solution (1.0 $\mathrm{M}$ in THF, $5.0 \mathrm{~mL}, 5.0 \mathrm{mmol}$ ) was added to a separate flame-dried flask. To this flask $\mathrm{ArMgBr} \bullet \mathrm{LiCl}$ was transferred via syringe. Often a white precipitate forms as the solution of $\mathrm{ArMgBr} \bullet \mathrm{LiCl}$ is added to the solution of $\mathrm{ZnCl}_{2}$, but the precipitate dissolves over the course of the addition. After 10 minutes, the solution of $\mathrm{ArZnCl} \bullet \mathrm{LiCl}$ was titrated with $\mathrm{I}_{2}$ in a manner similar to that reported by Knochel and coworkers (see below).

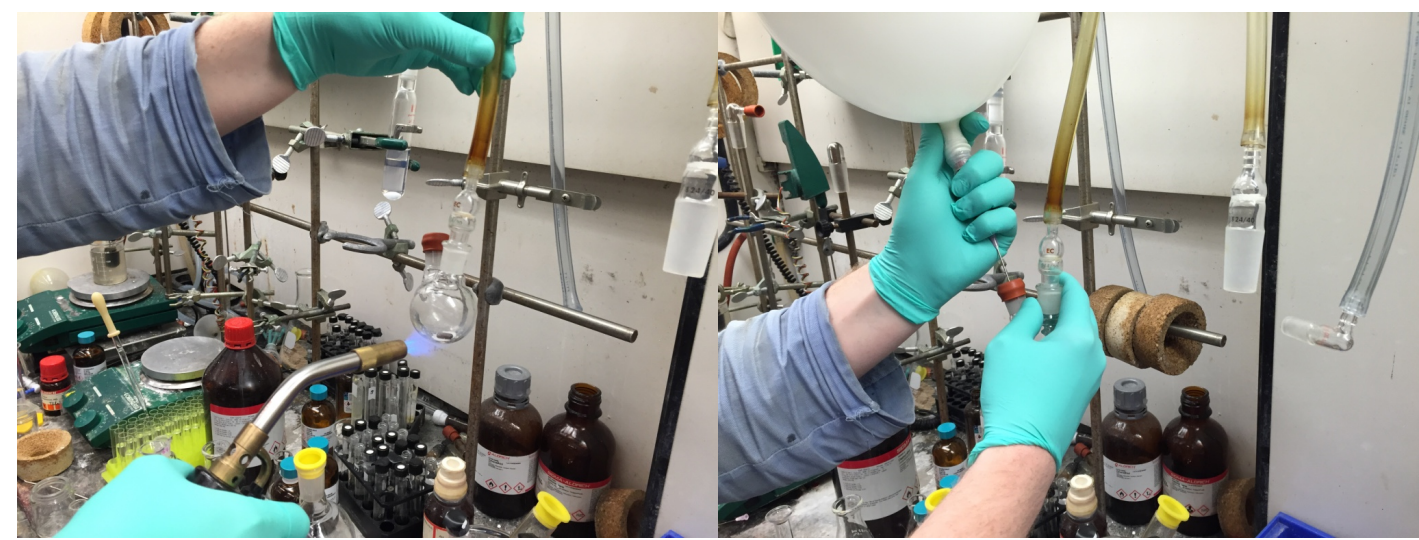

(Left) Flame-drying flask and $\mathrm{LiCl}$ under vacuum. (Right) Backfilling reaction vessel with Ar.

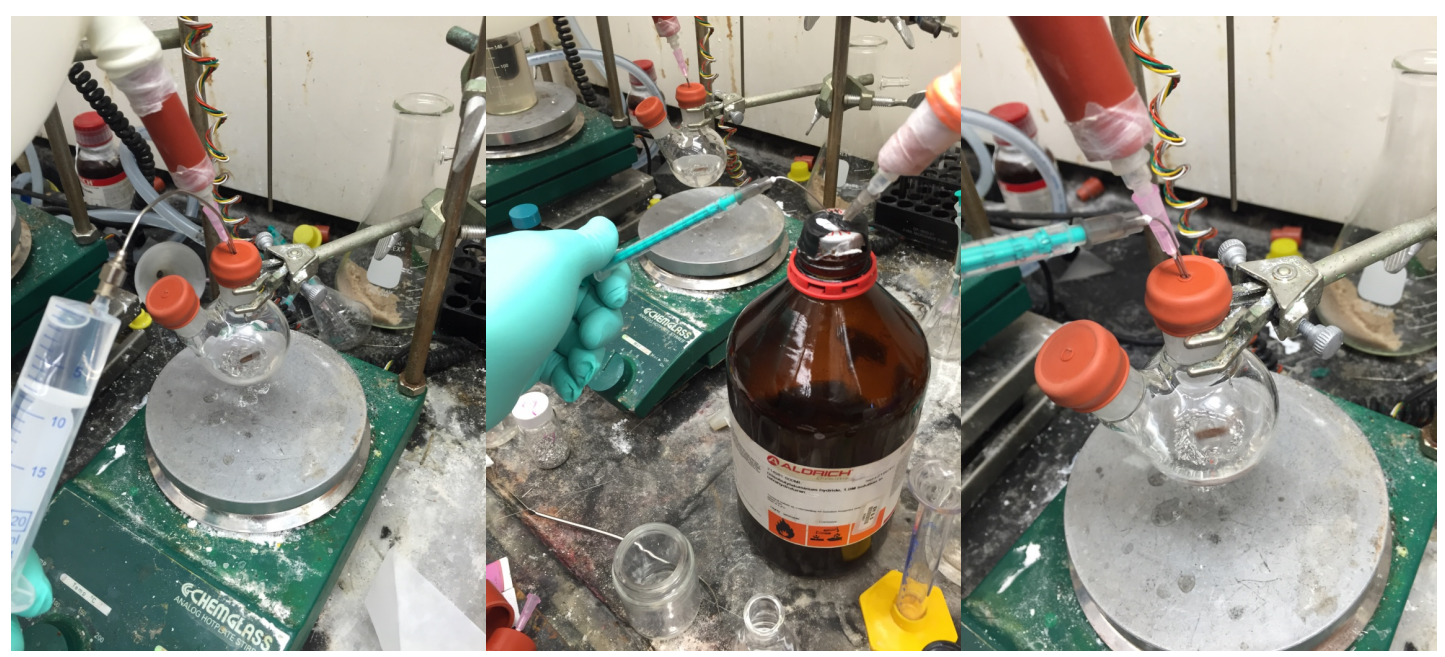

(Left) Addition of THF to Mg and LiCl. (Center and Right) Addition of DIBAL-H (1.0 M in THF) via syringe. 


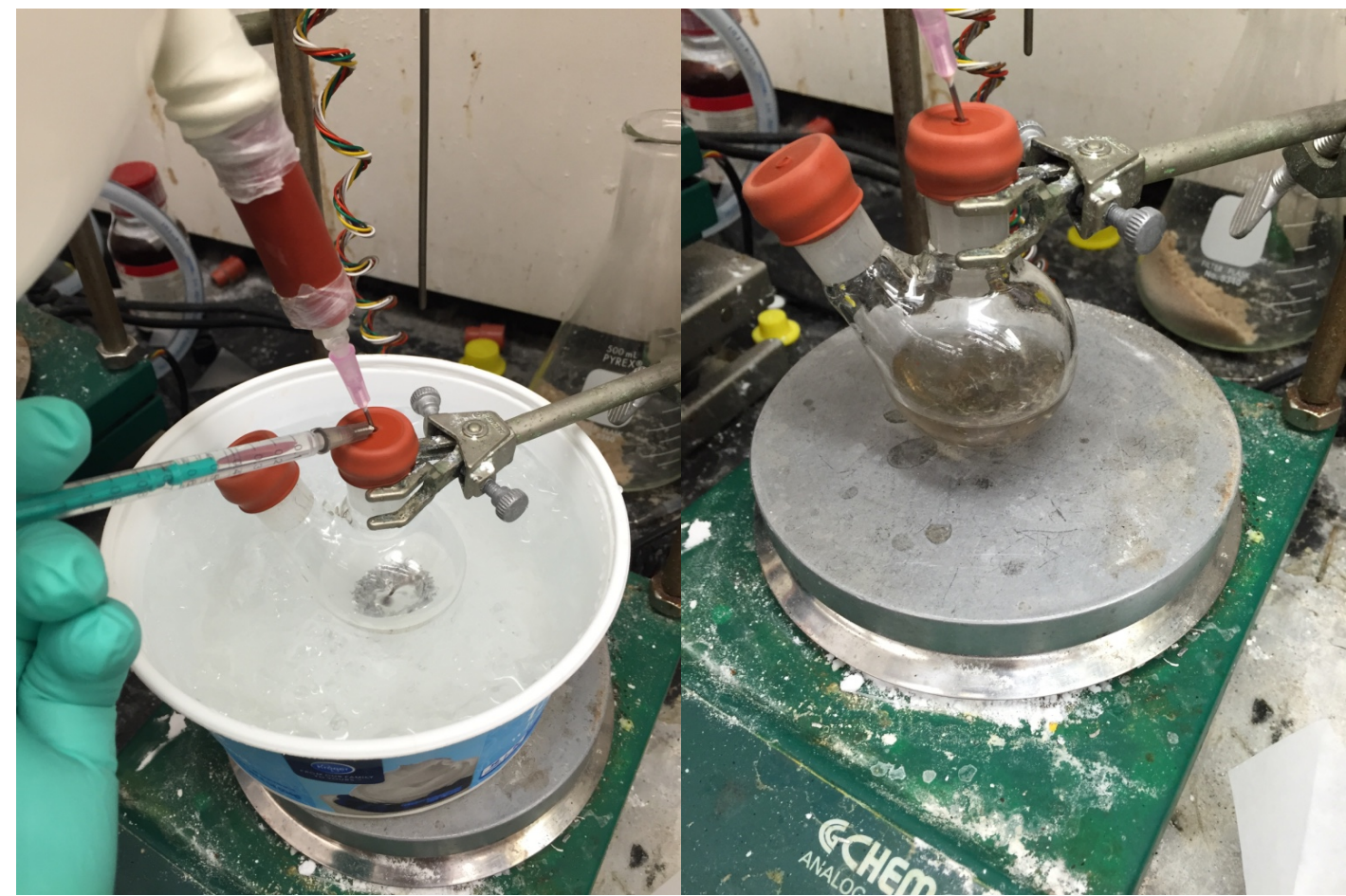

(Left) Addition of 3-bromoanisole at $0{ }^{\circ} \mathrm{C}$ (ice/water bath). (Right) Color change of solution after 30 minutes.

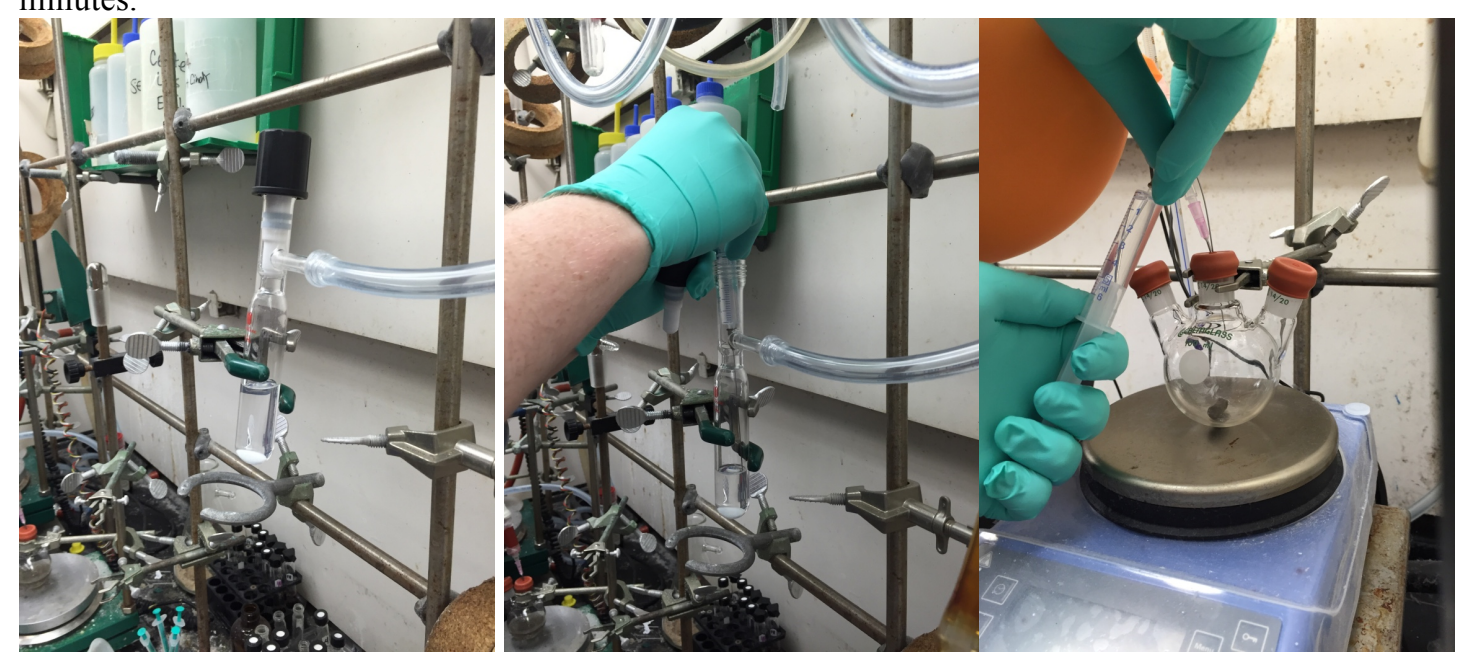

(Left) Schlenk-flask with $\mathrm{ZnCl}_{2}(1 \mathrm{M}$ in THF) is attached to a manifold nitrogen line. (Center and right) Addition of $\mathrm{ZnCl}_{2}$ solution to flame-dried flask under $\mathrm{Ar}$ atmosphere. 


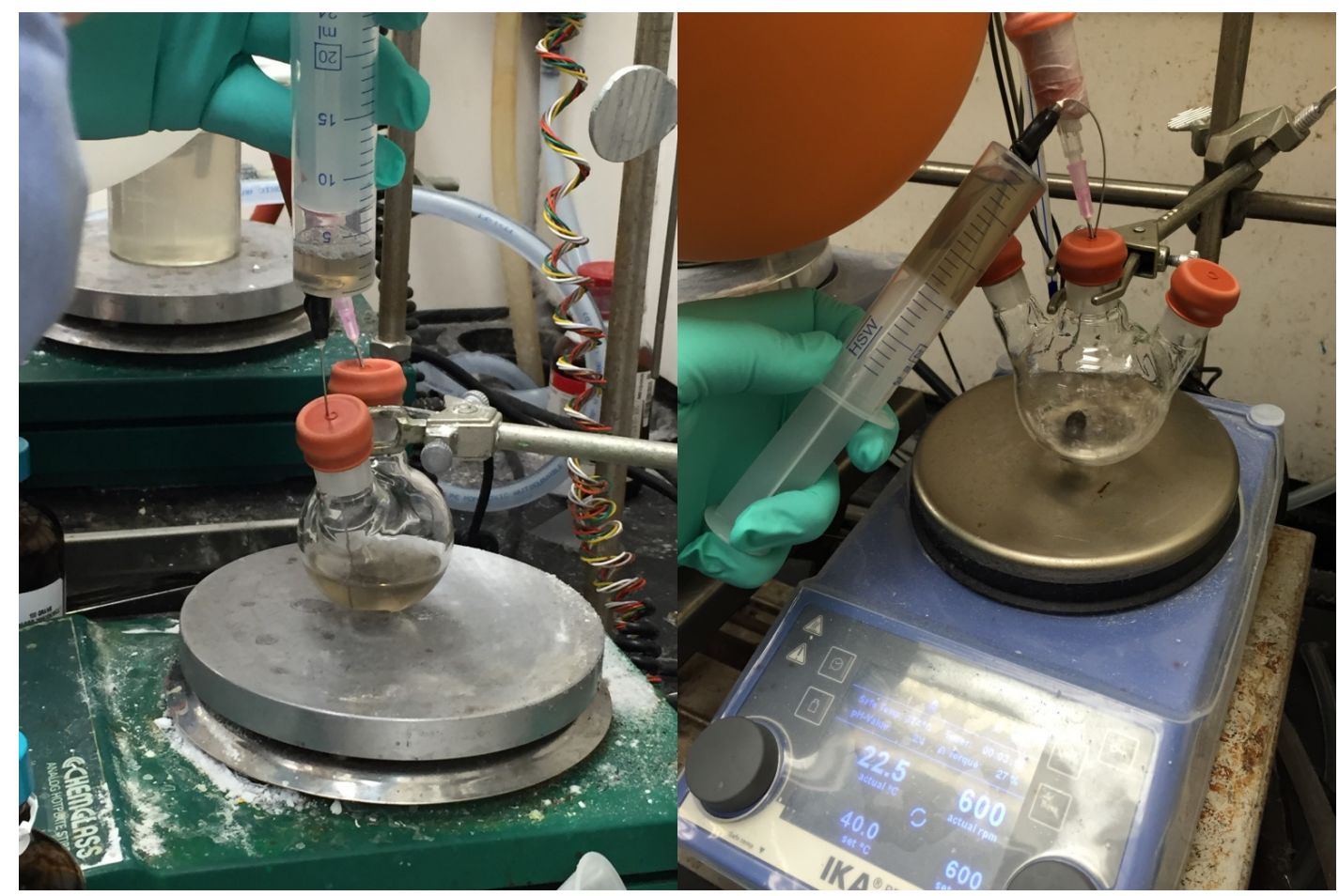

(Left) Removal of 3-OMePhMgBr$\bullet \mathrm{LiCl}$ (Right) Addition of 3-OMePhMgBr$\bullet \mathrm{LiCl}$ to $\mathrm{ZnCl}_{2}$ solution

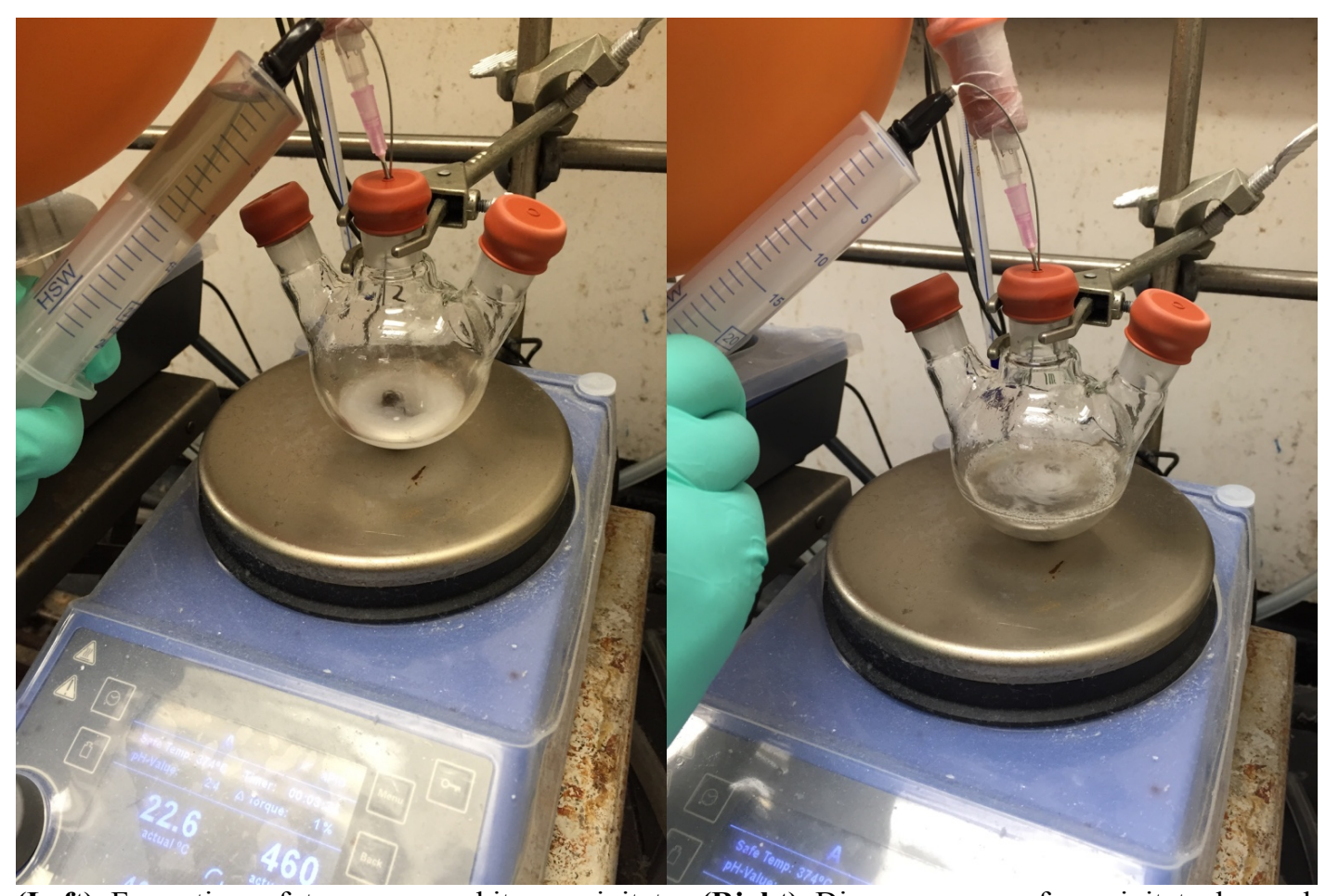

(Left) Formation of temporary white precipitate. (Right) Disappearance of precipitate by end of addition. Note: if preferred the $\mathrm{ZnCl}_{2}$ solution can be directly added to the flask in which the Grignard reagent was prepared. 


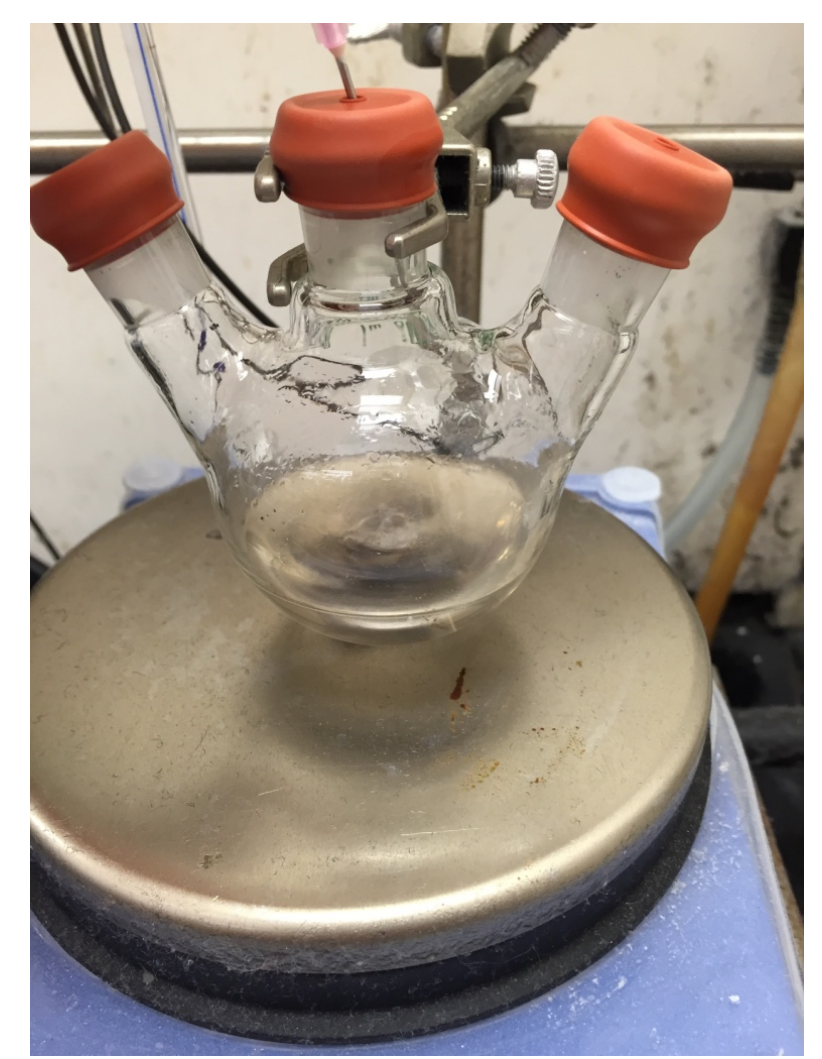

(Above) 3-OMePhZnCl• $\mathrm{LiCl}$ after 10 minutes of stirring.

\section{Titration of Arylzinc Reagents}

$\mathrm{LiCl}(0.021 \mathrm{~g}, 0.5 \mathrm{mmol})$ was added to a septum-containing screw-capped culture tube equipped with stir bar. The culture tube was flame-dried under vacuum and cooled under flow of Ar from a balloon. The cap was removed, $\mathrm{I}_{2}$ (approximately $0.024 \mathrm{~g}, 0.1 \mathrm{mmol}, 1.0$ equiv.) was quickly added to the culture tube, and the cap was replaced. The exact amount of $\mathrm{I}_{2}$ added was recorded. THF (anhydrous, $1.0 \mathrm{~mL}$ ) was added, and the mixture was stirred for 5 min to give a dark brown solution. A 1.00 $\mathrm{mL}$ syringe was filled with approximately $0.90 \mathrm{~mL}$ of $\mathrm{ArZnCl} \bullet \mathrm{LiCl}$, and the solution was added dropwise via the syringe. The exact volume of $\mathrm{ArZnCl} \cdot \mathrm{LiCl}$ solution in the syringe was recorded (titration start point). Over the course of the titration the color changes from dark brown to light brown to yellow to clear, indicating complete consumption of $\mathrm{I}_{2}$, and upon consumption of $\mathrm{I}_{2}$, the titration end point was recorded. The concentration of the $\mathrm{ArZnCl} \bullet \mathrm{LiCl}$ solution was then calculated. Typical concentrations of arylzinc reagents ranged from $0.18 \mathrm{M}$ to $0.24 \mathrm{M}$ in THF. 


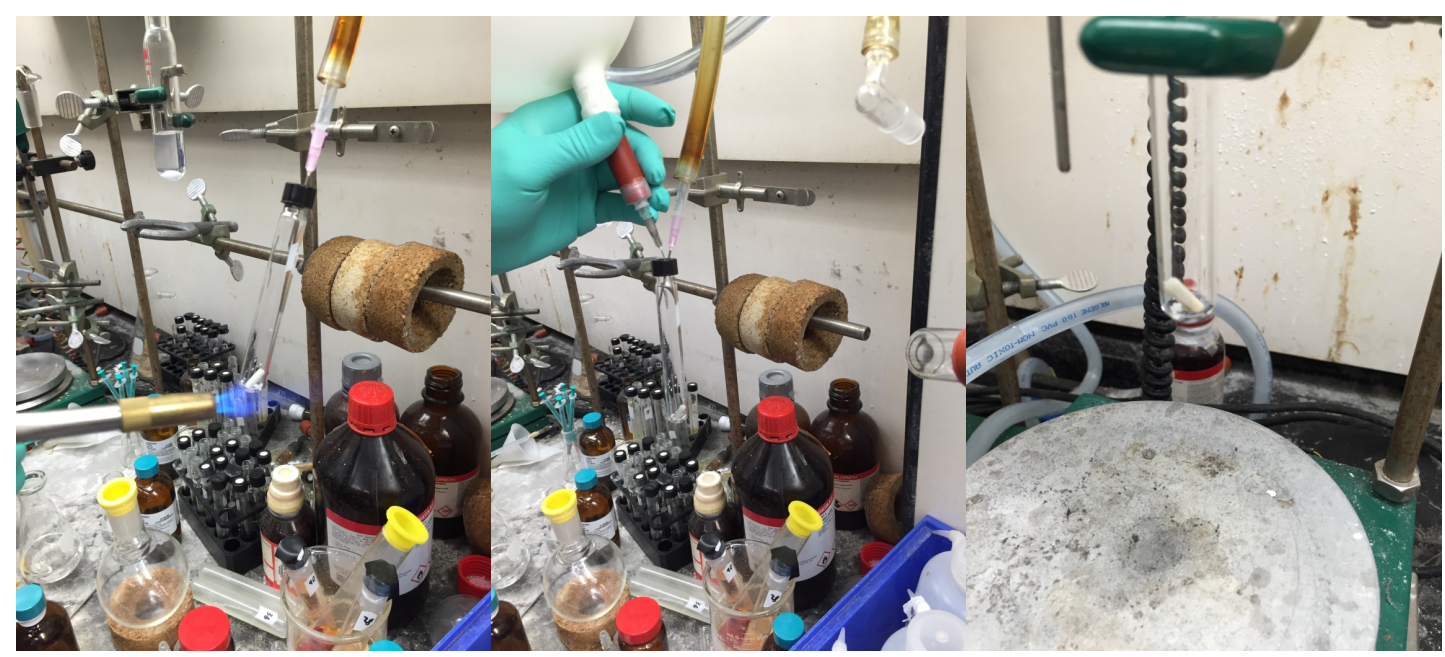

(Left) Flame-drying a culture tube equipped with stir bar and $\mathrm{LiCl}(0.5 \mathrm{mmol})$. (Center) Backfilling culture tube with Ar. (Right) Culture tube after cooling and addition of $\mathrm{I}_{2}(0.1 \mathrm{mmol})$.

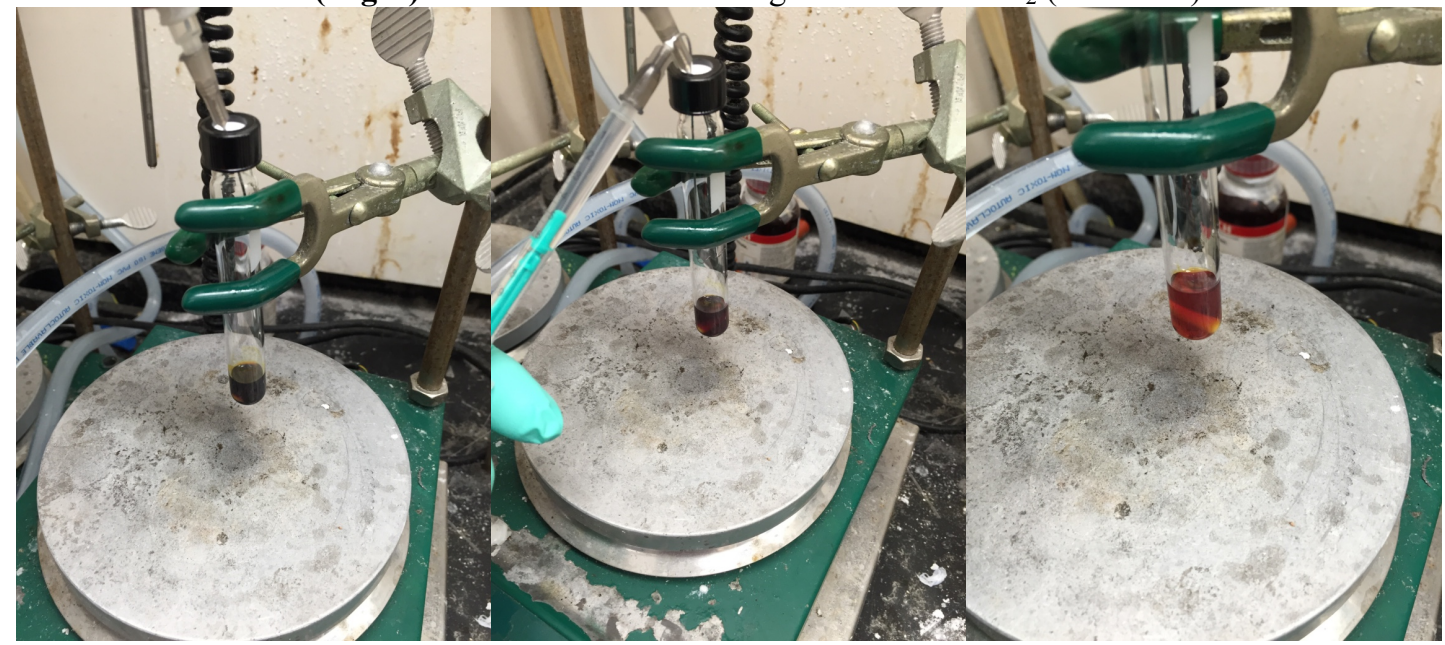

(Left) After addition of THF $(1.0 \mathrm{~mL})$ to $\mathrm{I}_{2}$ and $\mathrm{LiCl}$. (Center) Beginning of the titration. (Right) Progression of the titration.

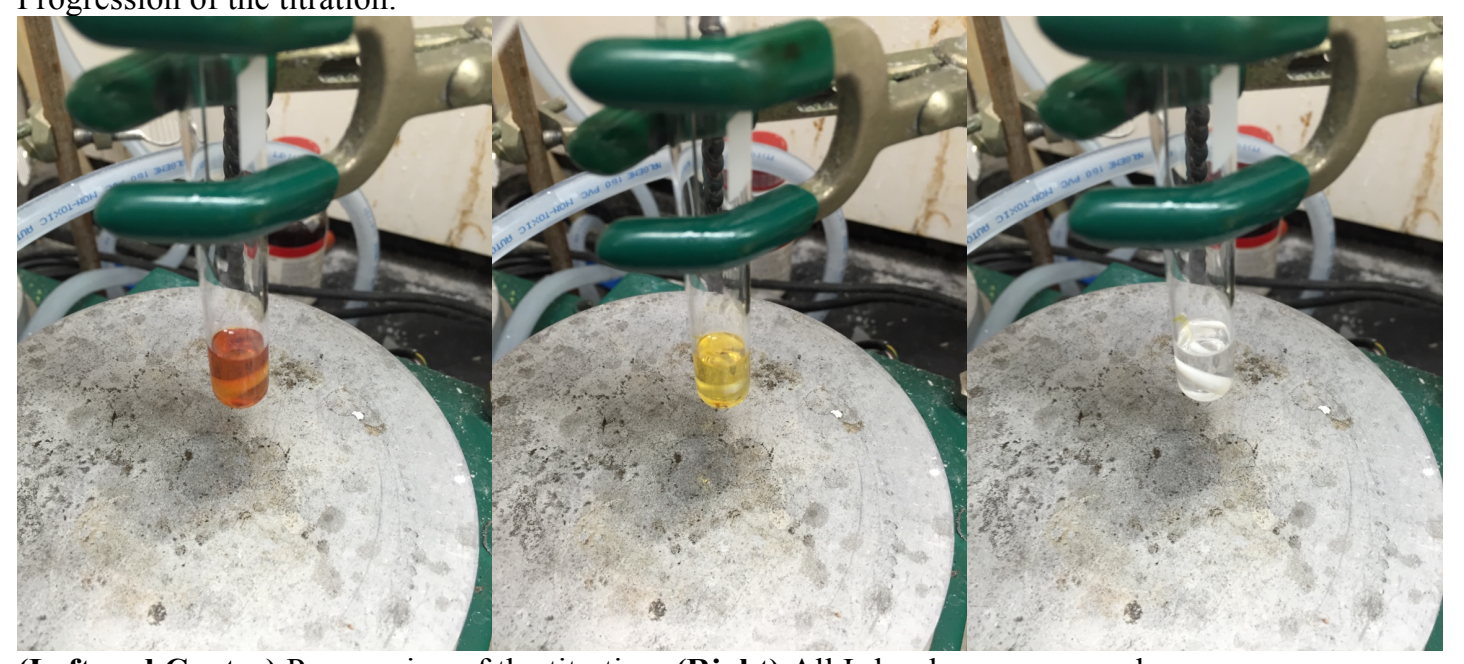

(Left and Center) Progression of the titration. (Right) All $\mathrm{I}_{2}$ has been consumed. 


\section{Optimization details}

Determining the yield by GC/FID: A screw-capped culture tube with Teflon ${ }^{\mathrm{TM}}$ septum containing a stirring bar was charged with $\mathrm{NiCl}_{2} \cdot$ glyme or $\mathrm{NiCl}_{2} \cdot 6 \mathrm{H}_{2} \mathrm{O}$, ligand and 1,3-dioxoisoindolin cyclopentylcarboxylate $N$-hydroxyphthalimide ester $(0.25 \mathrm{mmol}$, 1.0 equiv.) on the bench top. The tube was evacuated and back-filled with Ar. DMF (anhydrous) was added via syringe, and the mixture stirred for 2 minutes at $25{ }^{\circ} \mathrm{C}$. Then, $\mathrm{ArZnCl} \bullet \mathrm{LiCl}$ in THF was added in one portion, and the mixture was stirred for $14-16 \mathrm{~h}$ at $\mathrm{rt}$. The mixture was then quenched with $1 \mathrm{M} \mathrm{HCl}$ (approx. $2 \mathrm{~mL}$ ) and cyclooctane (1 equiv.) was added. The mixture was diluted with EtOAc, and an aliquot was taken, filtered through a short path of silica gel, and analyzed by GC/FID. Determining the yield by ${ }^{1} H$ NMR: The reaction was set up as above on $0.1 \mathrm{mmol}$ scale with 1,3-dioxoisoindolin-2-yl 2-ethylhexanoate (EtBu-NHPI ester), 4,5,6,7tetrachloro-1,3-dioxoisoindolin-2-yl 2-ethylhexanoate (EtBu-4Cl-NHPI ester), or 2ethylhexanoic acid with DIC (1.5 equiv.) and HOAt (1.0 equiv.) or HATU (1.0 equiv.) and $\mathrm{Et}_{3} \mathrm{~N}$ (1.0 equiv.). For activated esters formed in situ, the reaction mixture was stirred for $1 \mathrm{~h}$ prior to addition of [Ni] and ligand to the reaction mixture. After $16 \mathrm{~h}, 1 \mathrm{M} \mathrm{HCl}$ was added, and the mixture was diluted with $\mathrm{Et}_{2} \mathrm{O}$. The two layers were separated and the organic layer was washed with brine or $10 \% \mathrm{LiCl}$ (aq) to remove DMF. The organic layer was dried over anhydrous $\mathrm{NaSO}_{4}$ or $\mathrm{MgSO}_{4}$, filtered, and evaporated to dryness. $\mathrm{CDCl}_{3}(1-2 \mathrm{~mL})$ was added by pipette to the crude reaction mixture, $\mathrm{CH}_{2} \mathrm{Br}_{2}$ ( $0.125 \mathrm{mmol}, 0.5$ equiv) was added via microliter syringe, and the crude mixture was analyzed by ${ }^{1} \mathrm{H}$ NMR spectroscopy. 


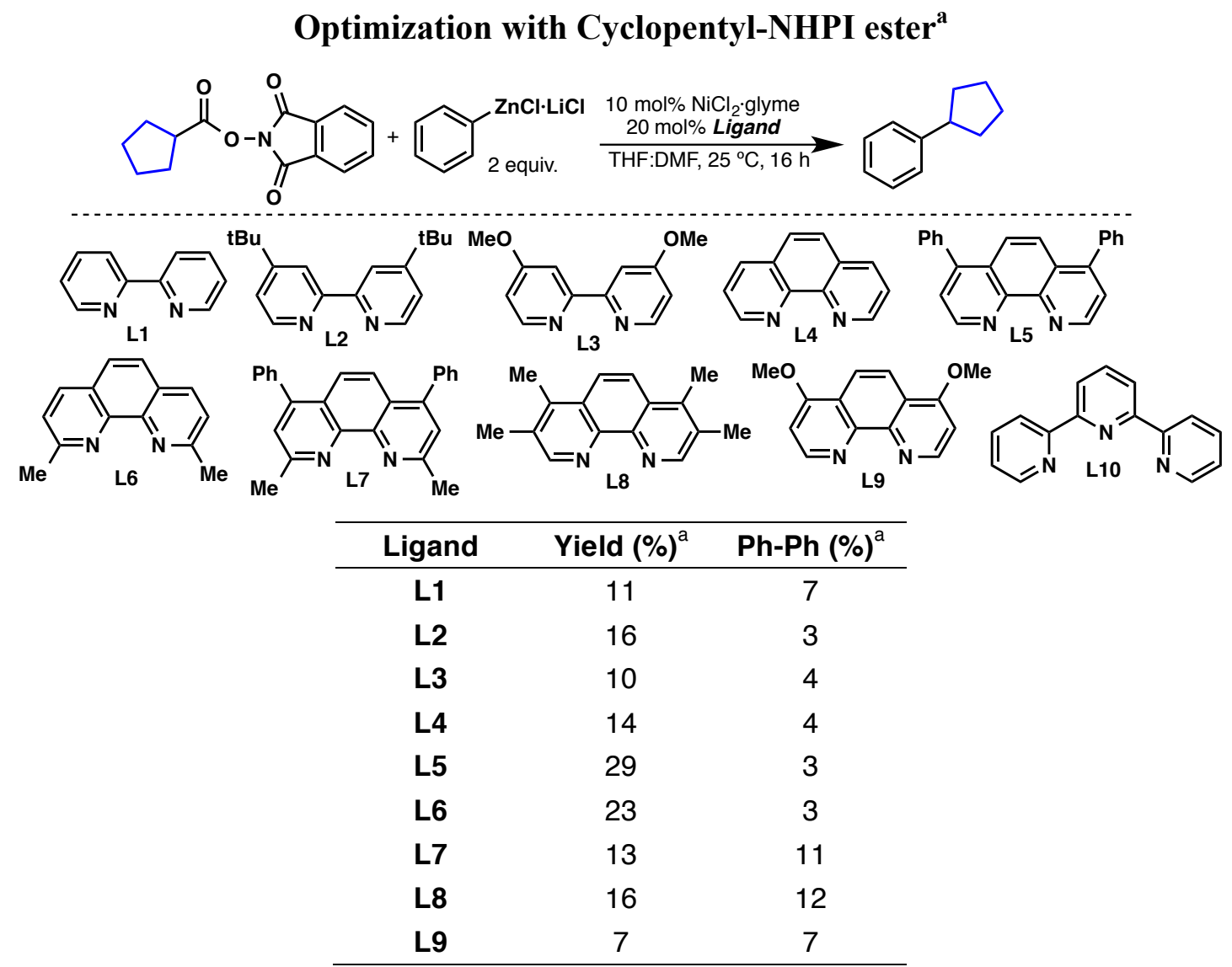

${ }^{a}$ Yields determined by GC/FID with cyclooctane as an internal standard

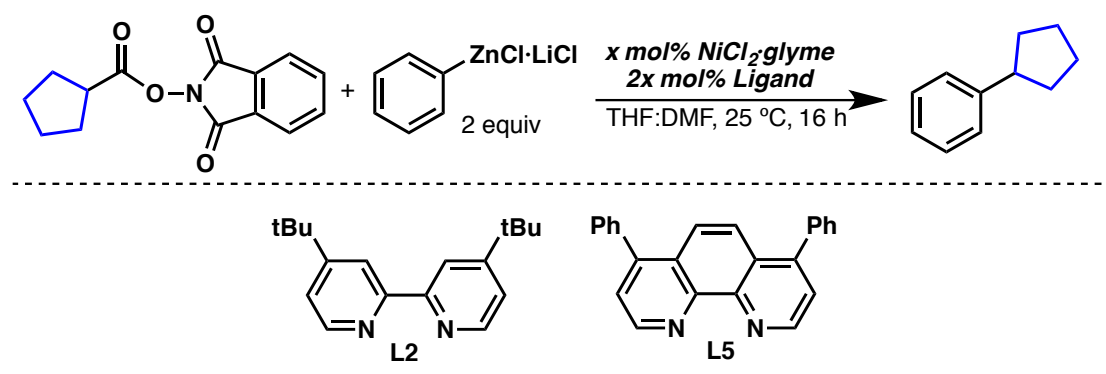

\begin{tabular}{cccc}
\hline Ligand & Ni/L ratio & ${\text { Yield }(\%)^{\text {a }}}^{\text {Ph-Ph (\%) }}$ \\
\hline L2 & $15: 30$ & 39 & 3 \\
L2 & $20: 40$ & 47 & 3 \\
L5 & $15: 30$ & 45 & 7 \\
L5 & $20: 40$ & 61 & 4
\end{tabular}

${ }^{\mathrm{a}}$ Yields determined by GC/FID with cyclooctane as an internal standard. 


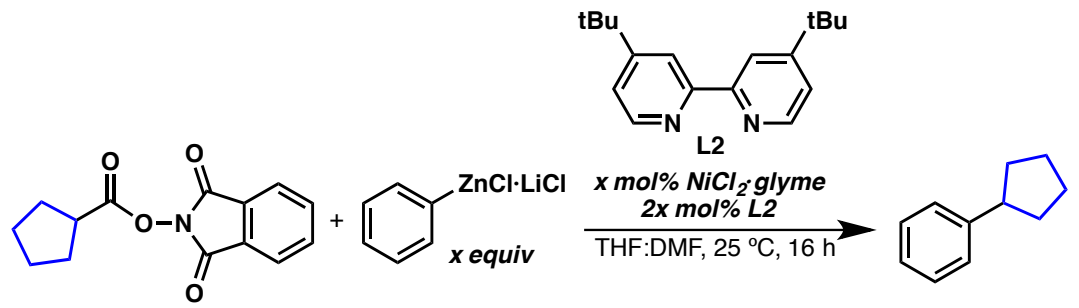

\begin{tabular}{cccc}
\hline Equiv. PhZnCl·LiCl & Ni:L ratio & $\begin{array}{c}\text { Yield } \\
\text { (\%) }^{\mathbf{a}}\end{array}$ & Ph-Ph (\%) \\
\hline 3.0 & $10: 20$ & 67 & 6 \\
3.0 & $15: 30$ & 55 & 16 \\
3.0 & $20: 40$ & 91 & 11 \\
4.0 & $10: 20$ & 93 & 30 \\
4.0 & $15: 30$ & 85 & 22 \\
4.0 & $20: 40$ & 99 & 2 \\
\hline
\end{tabular}

${ }^{\mathrm{a}}$ Yields determined by GC/FID with cyclooctane as an internal standard.

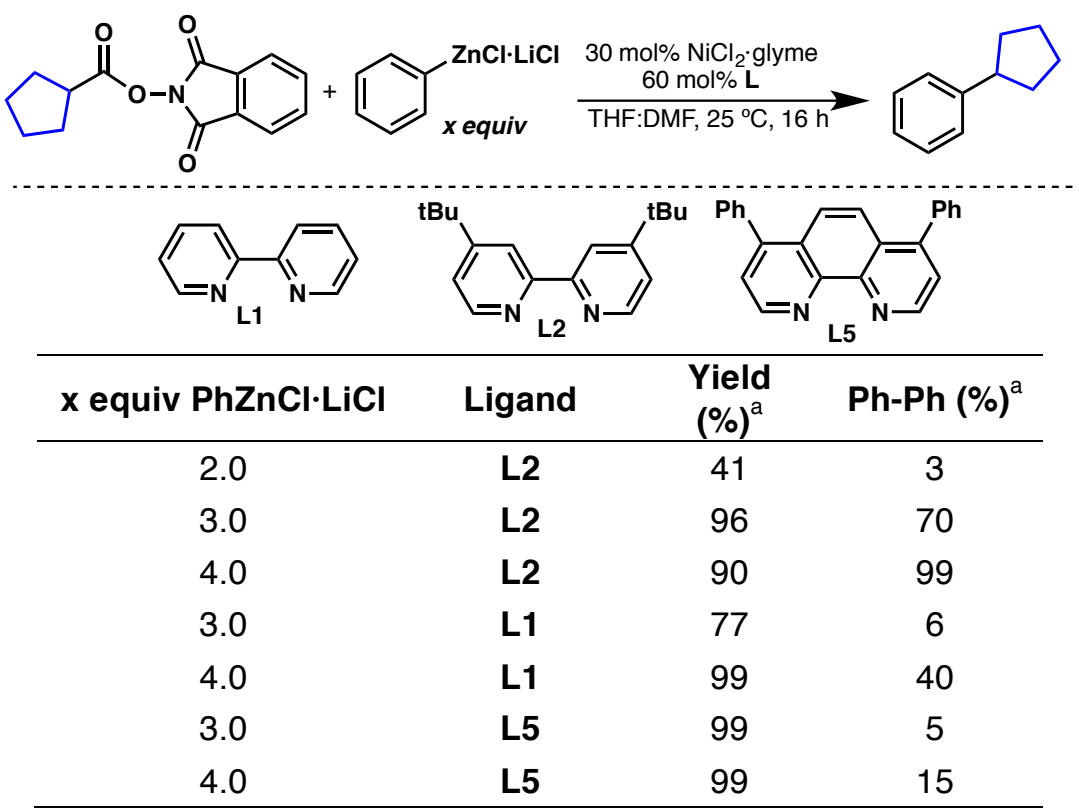

\section{Optimization with Et,Bu-NHPI ester ${ }^{\text {a,b }}$}

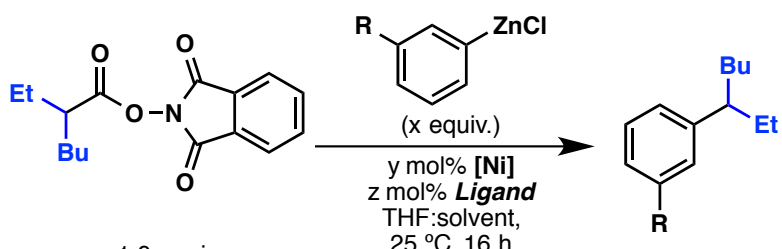

\begin{tabular}{cccccccc}
\hline $\mathbf{R}$ & [Ni] & $\begin{array}{c}\text { Mol } \\
\%\end{array}$ & $\mathbf{L}$ & $\begin{array}{c}\text { Mol \% } \\
\mathbf{L}\end{array}$ & $\begin{array}{c}\text { Equiv. } \\
\text { PhZnCl・LiCl }\end{array}$ & $\begin{array}{c}\text { THF: } \\
\text { DMF }\end{array}$ & Yield (\%) \\
\hline $\mathrm{OMe}$ & $\mathrm{NiCl}_{2} \bullet$ glyme & 15 & $\mathbf{L 1}$ & 15 & 2.0 & $1: 1$ & 43 \\
$\mathrm{OMe}$ & $\mathrm{NiCl}_{2} \bullet$ glyme & 15 & $\mathbf{L 1}$ & 18.75 & 2.0 & $1: 1$ & 30 \\
$\mathrm{OMe}$ & $\mathrm{NiCl}_{2} \bullet$ glyme & 15 & $\mathbf{L 1}$ & 30 & 2.0 & $1: 1$ & 63 \\
$\mathrm{OMe}$ & $\mathrm{NiCl}_{2} \bullet \mathrm{glyme}$ & 15 & $\mathbf{L 1 / L 2}$ & $15 / 15$ & 2.0 & $1: 1$ & 67 \\
\hline
\end{tabular}




\begin{tabular}{cccccccc}
\hline $\mathrm{OMe}$ & $\mathrm{NiCl}_{2} \bullet \mathrm{glyme}$ & 20 & L2 & 40 & 3.0 & $1: 1$ & $65^{\mathrm{b}}$ \\
$\mathrm{H}$ & $\mathrm{NiCl}_{2} \bullet$ glyme & 30 & L1 & 60 & 3.0 & $1: 1$ & 80 \\
$\mathrm{H}$ & $\mathrm{NiCl}_{2} \bullet$ glyme & 30 & L2 & 60 & 3.0 & $1: 1$ & 86 \\
$\mathrm{H}$ & $\mathrm{NiCl}_{2} \bullet \mathrm{glyme}$ & 20 & L2 & 40 & 3.0 & $2: 1$ & $92^{\mathrm{b}}$ \\
$\mathrm{H}$ & $\mathrm{NiCl}_{2} \bullet 6 \mathrm{H}_{2} \mathrm{O}$ & 20 & L2 & 40 & 3.0 & $2: 1$ & $93^{\mathrm{b}}$ \\
\hline
\end{tabular}

${ }^{a}$ Yield determined by ${ }^{\mathrm{I}} \mathrm{H}$ NMR analysis with $\mathrm{CH}_{2} \mathrm{Br}_{2}$ as an internal standard ${ }^{b}$ Isolated yield $(0.25$ mmol scale).

\section{Optimization with -OAt Esters Generated in situ ${ }^{a, b}$}

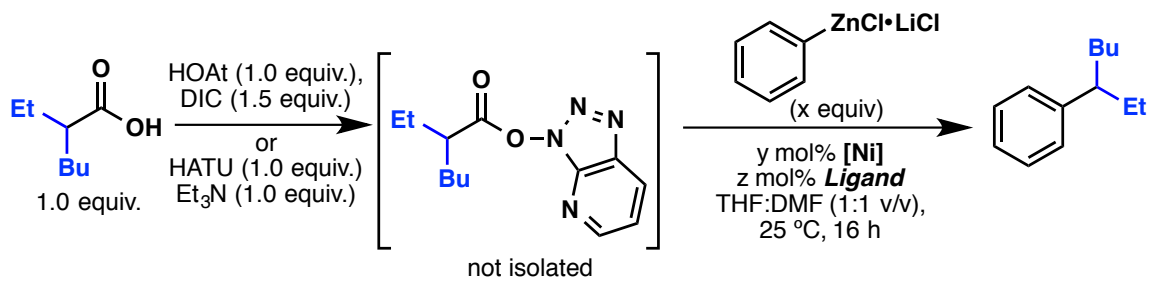

\begin{tabular}{|c|c|c|c|c|c|c|c|}
\hline$[\mathrm{Ni}]$ & Mol \% & $\mathbf{L}$ & $\begin{array}{c}\text { Mol \% } \\
\text { L }\end{array}$ & {$[\mathrm{Ni}] / \mathrm{L}$} & $\begin{array}{c}\text { Equiv. } \\
\text { PhZnCl•LiCl }\end{array}$ & $\begin{array}{l}\text { Additive } \\
\text { (equiv.) }\end{array}$ & Yield (\%) \\
\hline $\mathrm{NiCl}_{2} \bullet$ glyme & 1 & L2 & 1 & $1: 1$ & 4.0 & - & 11 \\
\hline $\mathrm{NiCl}_{2} \bullet$ glyme & 2.5 & L2 & 2.5 & $1: 1$ & 4.0 & - & 21 \\
\hline $\mathrm{NiCl}_{2} \bullet$ glyme & 5.0 & L2 & 5.0 & $1: 1$ & 4.0 & - & 23 \\
\hline $\mathrm{NiCl}_{2} \bullet$ glyme & 7.5 & L2 & 10 & $1: 1$ & 4.0 & - & 27 \\
\hline $\mathrm{NiCl}_{2} \bullet$ glyme & 10 & L2 & 10 & $1: 1$ & 1.0 & - & 11 \\
\hline $\mathrm{NiCl}_{2} \bullet$ glyme & 10 & L2 & 10 & $1: 1$ & 2.0 & - & 27 \\
\hline $\mathrm{NiCl}_{2} \bullet$ glyme & 10 & L2 & 10 & $1: 1$ & 3.0 & - & 29 \\
\hline $\mathrm{NiCl}_{2} \bullet$ glyme & 10 & L2 & 10 & $1: 1$ & 4.0 & - & 33 \\
\hline $\mathrm{NiCl}_{2} \bullet$ glyme & 10 & L4 & 10 & $1: 1$ & 4.0 & - & 35 \\
\hline $\mathrm{NiCl}_{2} \bullet$ glyme & 10 & L7 & 10 & $1: 1$ & 4.0 & - & 24 \\
\hline $\mathrm{NiCl}_{2} \bullet$ glyme & 10 & L9 & 10 & $1: 1$ & 4.0 & - & 20 \\
\hline $\mathrm{NiCl}_{2} \bullet$ glyme & 10 & L10 & 10 & $1: 1$ & 4.0 & - & 15 \\
\hline $\mathrm{NiCl}_{2} \bullet$ glyme & 10 & L1 & 10 & $1: 1$ & 4.0 & - & 36 \\
\hline $\mathrm{NiCl}_{2} \bullet$ glyme & 10 & L5 & 10 & $1: 1$ & 4.0 & - & 40 \\
\hline $\mathrm{NiCl}_{2} \bullet$ glyme & 10 & - & - & $1: 1$ & 4.0 & - & 8 \\
\hline $\mathrm{NiCl}_{2} \bullet$ glyme & 10 & L2 & 10 & $1: 1$ & 2.0 & $\begin{array}{c}\text { TMEDA } \\
(0.1)\end{array}$ & 35 \\
\hline $\mathrm{Ni}(\text { acac })_{2}$ & 10 & L2 & 10 & $1: 1$ & 2.0 & - & 30 \\
\hline $\mathrm{NiCl}_{2} \bullet$ glyme & 10 & L2 & 20 & $1: 2$ & 2.0 & - & $48(41)^{b}$ \\
\hline
\end{tabular}

${ }^{a}$ Yield determined by ${ }^{1} \mathrm{H}$ NMR analysis with $\mathrm{CH}_{2} \mathrm{Br}_{2}$ as an internal standard. ${ }^{b}$ Isolated yield $(0.25$ mmol scale). 


\section{Optimization with 4 Cl-NHPI esters ${ }^{a, b}$}

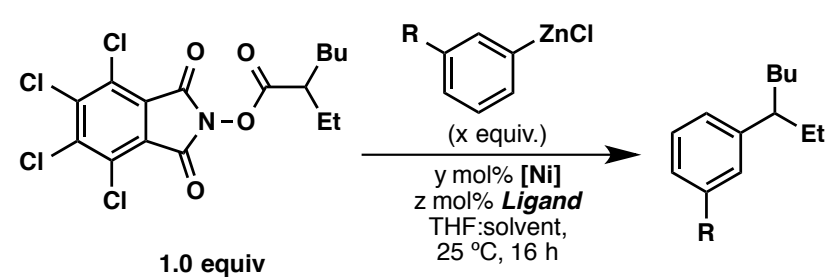

\begin{tabular}{ccccccccc}
\hline $\mathbf{R}$ & [Ni] & $\begin{array}{c}\text { Mol } \\
\%\end{array}$ & $\mathbf{L}$ & $\mathbf{M o l} \% \mathbf{L}$ & $\begin{array}{c}\text { Equiv. } \\
\text { PhZnCl.LiCl }\end{array}$ & $\begin{array}{c}\text { THF:DMF } \\
\text { (0.2 } \\
\text { equiv.) }\end{array}$ & $\begin{array}{c}\text { Additive } \\
\text { Yield (\%) }\end{array}$ \\
\hline $\mathrm{H}$ & $\mathrm{NiCl}_{2} \bullet$ glyme & 10 & $\mathbf{L 1}$ & 20 & 2.0 & $1: 1$ & - & 61 \\
$\mathrm{H}$ & $\mathrm{NiCl}_{2} \bullet$ glyme & 10 & $\mathbf{L 2}$ & 20 & 2.0 & $1: 1$ & - & 45 \\
$\mathrm{H}$ & $\mathrm{NiCl}_{2} \bullet$ glyme & 20 & $\mathbf{L 2}$ & 20 & 2.0 & $1: 0$ & - & 50 \\
$\mathrm{H}$ & $\mathrm{NiCl}_{2} \bullet$ glyme & 10 & $\mathbf{L 3}$ & 20 & 2.0 & $1: 1$ & - & 58 \\
$\mathrm{H}$ & $\mathrm{NiCl}_{2} \bullet$ glyme & 10 & $\mathbf{L 4}$ & 20 & 2.0 & $1: 1$ & - & 59 \\
$\mathrm{H}$ & $\mathrm{NiCl}_{2} \bullet$ glyme & 10 & $\mathbf{L 5}$ & 20 & 2.0 & $1: 1$ & - & 49 \\
$\mathrm{H}$ & $\mathrm{NiCl}_{2} \bullet$ glyme & 10 & $\mathbf{L 6}$ & 20 & 2.0 & $1: 1$ & - & 35 \\
$\mathrm{H}$ & $\mathrm{NiCl}_{2} \bullet$ glyme & 10 & $\mathbf{L 7}$ & 20 & 2.0 & $1: 1$ & - & 46 \\
$\mathrm{H}$ & $\mathrm{NiCl}_{2} \bullet$ glyme & 10 & $\mathbf{L 8}$ & 20 & 2.0 & $1: 1$ & - & 35 \\
$\mathrm{H}$ & $\mathrm{NiCl}_{2} \bullet$ glyme & 10 & $\mathbf{L 9}$ & 20 & 2.0 & $1: 1$ & - & 34 \\
$\mathrm{H}$ & $\mathrm{NiCl}_{2} \bullet$ glyme & 10 & $\mathbf{L 1 0}$ & 20 & 2.0 & $1: 1$ & - & 64 \\
$\mathrm{OMe}$ & $\mathrm{NiCl}_{2} \bullet$ glyme & 10 & $\mathbf{L 1}$ & 20 & 2.0 & $1: 1$ & - & 58 \\
$\mathrm{OMe}$ & $\mathrm{NiCl}_{2} \bullet$ glyme & 10 & $\mathbf{L 1}$ & 20 & 2.0 & $1: 0$ & - & 54 \\
$\mathrm{OMe}$ & $\mathrm{NiCl}_{2} \bullet$ glyme & 10 & $\mathbf{L 1}$ & 10 & 2.0 & $1: 1$ & TMEDA & 45 \\
$\mathrm{OMe}$ & $\mathrm{NiCl}_{2} \bullet$ glyme & 15 & $\mathbf{L 1}$ & 30 & 2.0 & $1: 1$ & - & 71 \\
$\mathrm{OMe}$ & $\mathrm{NiCl}_{2} \bullet$ glyme & 20 & $\mathbf{L 1}$ & 40 & 2.0 & $1: 1$ & - & 70 \\
\hline
\end{tabular}

${ }^{a}$ Yield determined by ${ }^{1} \mathrm{H}$ NMR analysis with $\mathrm{CH}_{2} \mathrm{Br}_{2}$ as an internal standard.

General Procedure for the Ni-catalyzed cross-coupling reaction (General Procedure B).

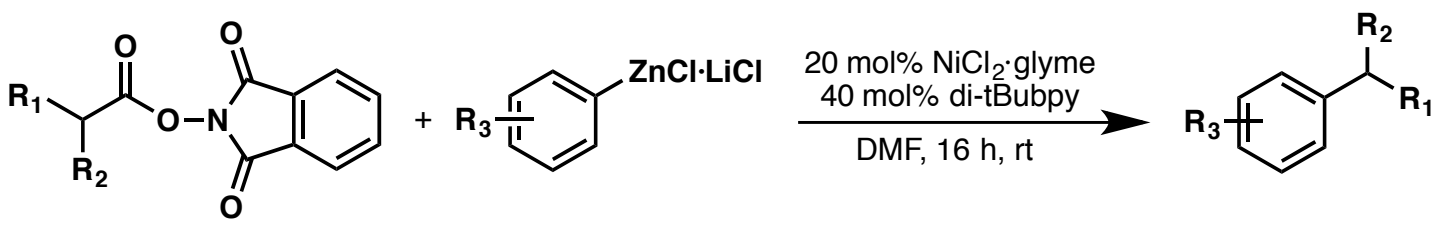

A culture tube with a Teflon ${ }^{\mathrm{TM}}$ septum screw-cap and stir bar was charged with $\mathrm{NiCl}_{2} \cdot$ glyme or $\mathrm{NiCl}_{2} \cdot 6 \mathrm{H}_{2} \mathrm{O}(20 \mathrm{~mol} \%)$, di- $t$ Bubipy (40 mol\%) and (if solid) NHPIester (1.0 equiv.). The tube was evacuated and backfilled with Ar. Reactions were run with a 3:2 ratio of THF:DMF. The volume of DMF used was calculated based on the titre of the THF solution of the arylzinc reagent. DMF (anhydrous) was added via syringe, and the mixture stirred for 2 minutes at $\mathrm{rt}$ for solid NHPI-esters. NHPI-ester (if liquid) was dissolved in DMF (anhydrous) and added to the culture tube containing [Ni] and di-tBubipy, and the mixture was stirred for 2 minutes at rt. Then, arylzinc 
reagent in THF (3.0 equiv.) was added in one portion, and the mixture was stirred for $12-16 \mathrm{~h}$ at rt. The mixture was diluted with EtOAc or $\mathrm{Et}_{2} \mathrm{O}$ and quenched with $1 \mathrm{M}$ $\mathrm{HCl}(\mathrm{aq})$. The reaction can also be quenched with $\mathrm{H}_{2} \mathrm{O}$ or half-saturated $\mathrm{NH}_{4} \mathrm{Cl}(\mathrm{aq})$ solution for acid-sensitive substrates. The organic layer was washed with $\mathrm{H}_{2} \mathrm{O}$ and brine, dried over anhydrous $\mathrm{Na}_{2} \mathrm{SO}_{4}$, and concentrated under reduced pressure (CAUTION: some of the products are volatile). The crude material was purified by silica gel column chromatography or preparative TLC. Note: for in situ preparation of -OAt or -OBt esters with HATU or HBTU, respectively, see 25.

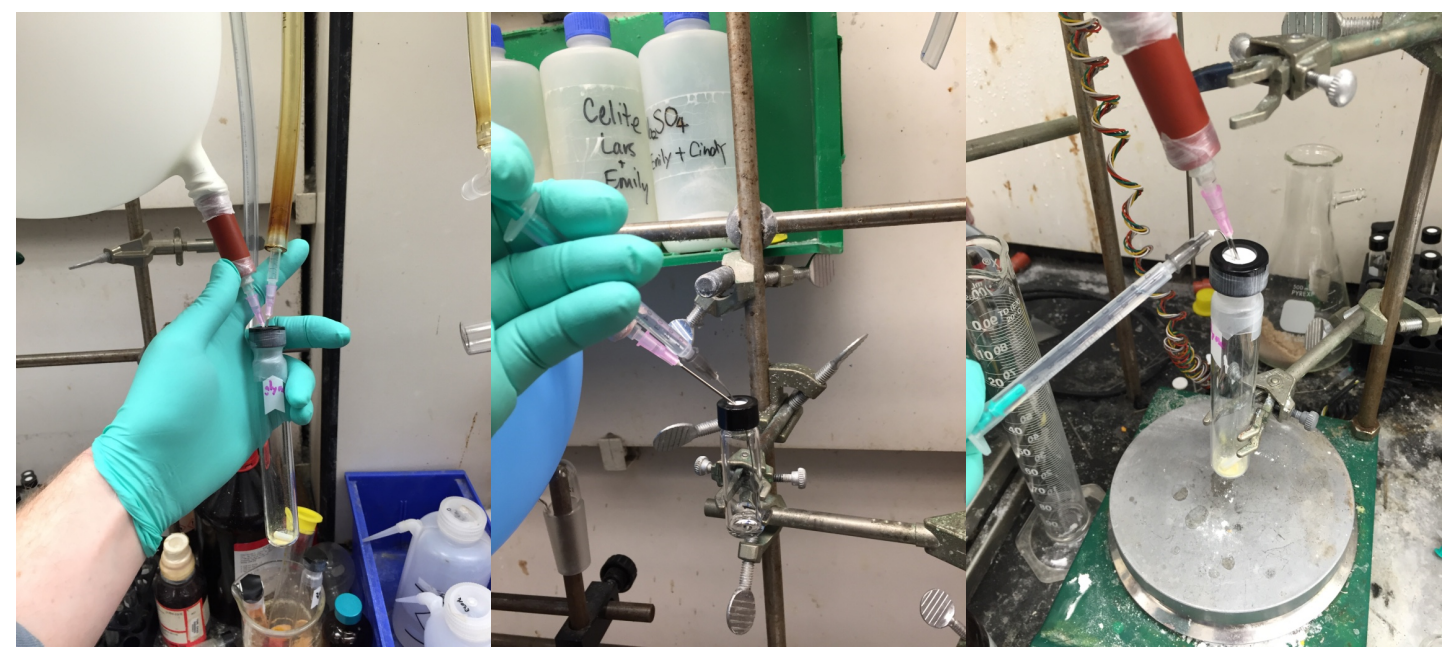

(Left) Backfilling with Ar a culture tube containing $\mathrm{NiCl}_{2} \bullet$ glyme, di-tBubipy, and a stir bar. (Center) A solution of 1,3-dioxoisoindolin-2-yl 2-ethylhexanoate in DMF (Right) Adding the solution of DMF and redox-active ester to the culture tube.
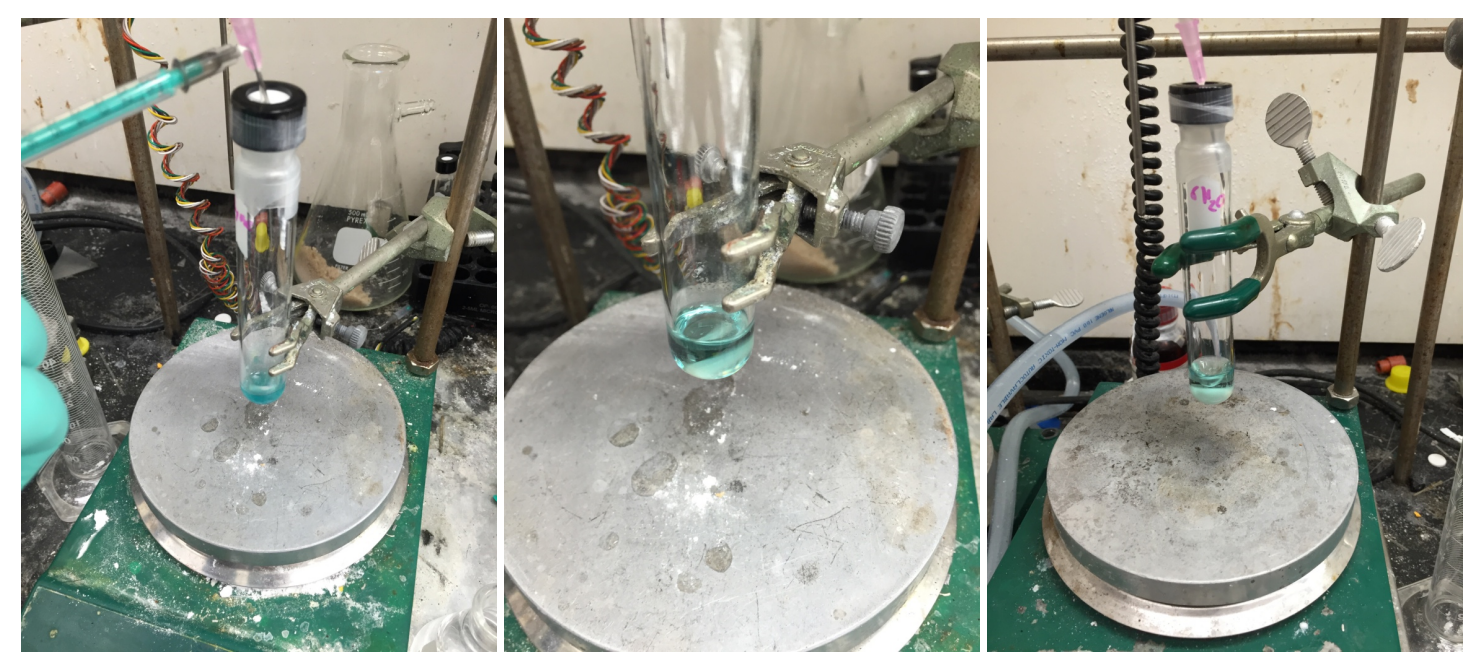

(Left) Blue color develops as the DMF solution is added. (Center) After all of the redox-active ester solution has been added and stirred for 5 min. (Right) Same as before with $\mathrm{NiCl}_{2} \bullet 6 \mathrm{H}_{2} \mathrm{O}$. 

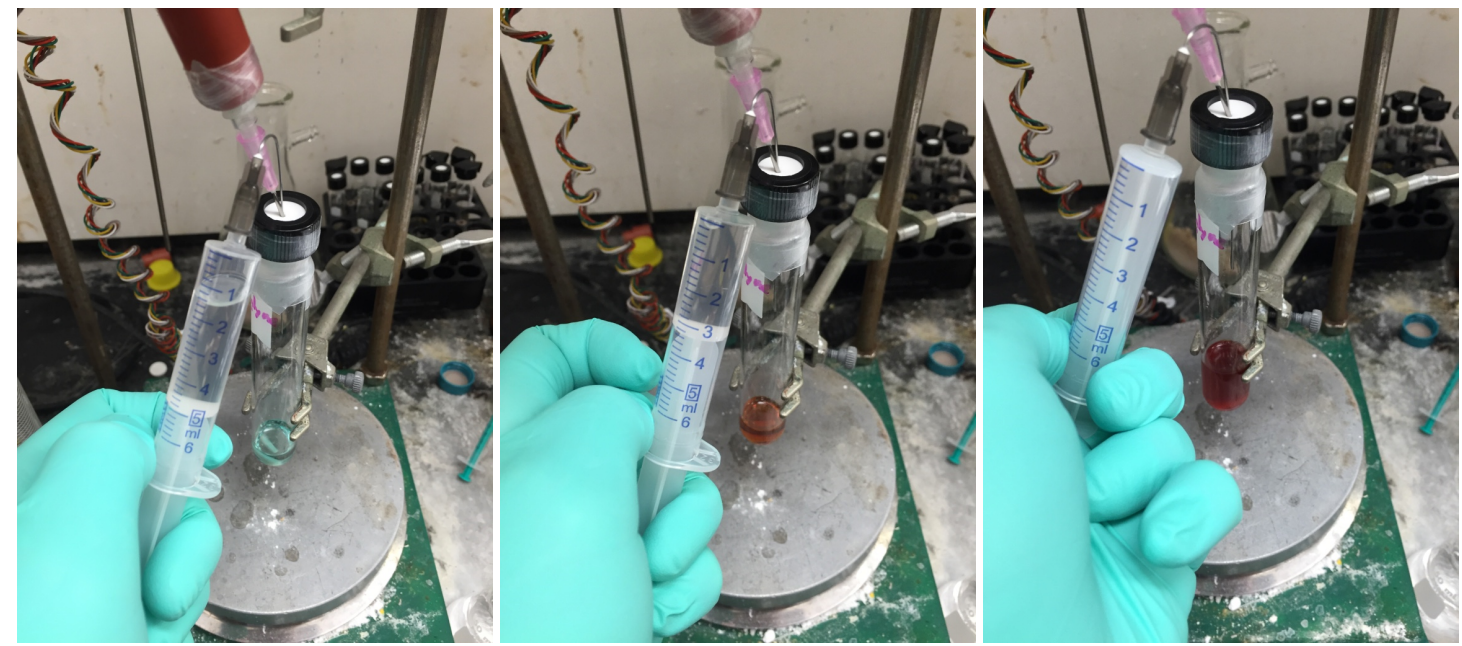

(Left) Prior to addition of 3-OMePhZnCl• $\mathrm{LiCl}$. (Center) A red/brown color is immediately evident. (Right) Completed addition of $3-\mathrm{OMePhZnCl} \cdot \mathrm{LiCl}$ solution.

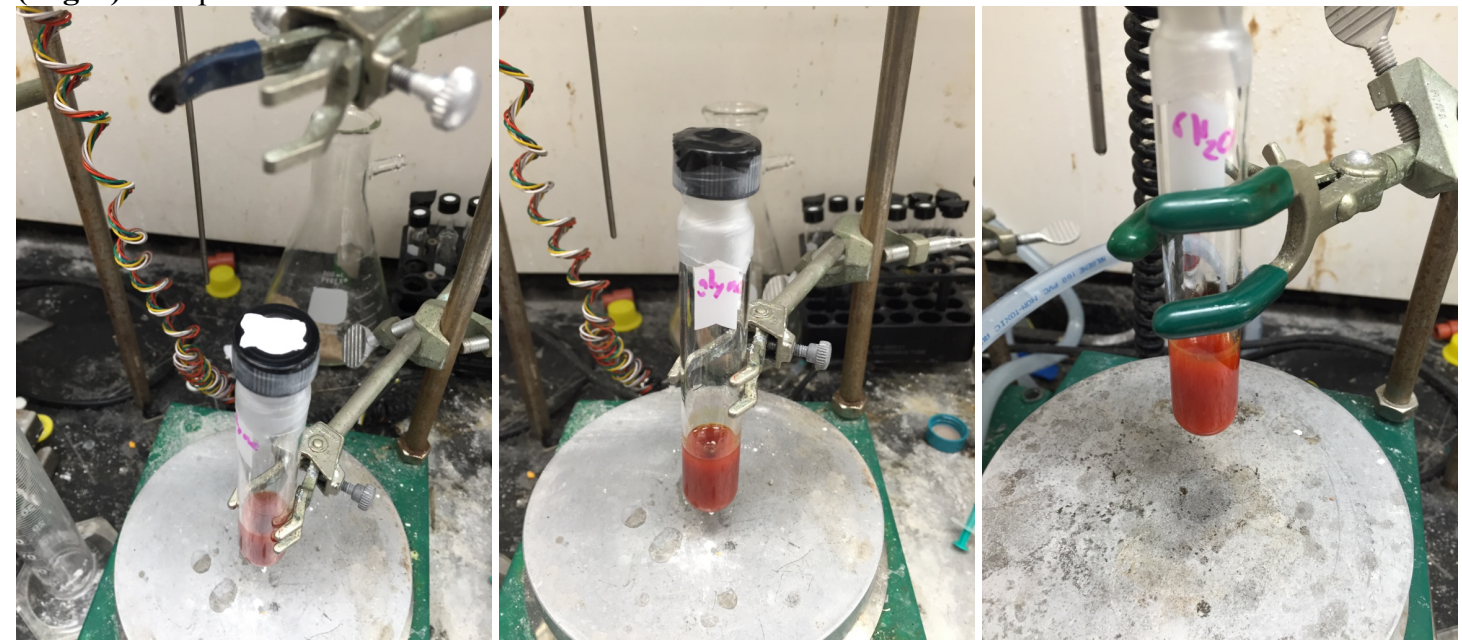

(Left) Removal of Ar balloon and covering septum with Teflon ${ }^{\mathrm{TM}}$ tape. (Center) Covering the Teflon ${ }^{\mathrm{TM}}$ tape with electrical tape. (Right) Same as before with $\mathrm{NiCl}_{2} \bullet 6 \mathrm{H}_{2} \mathrm{O}$.

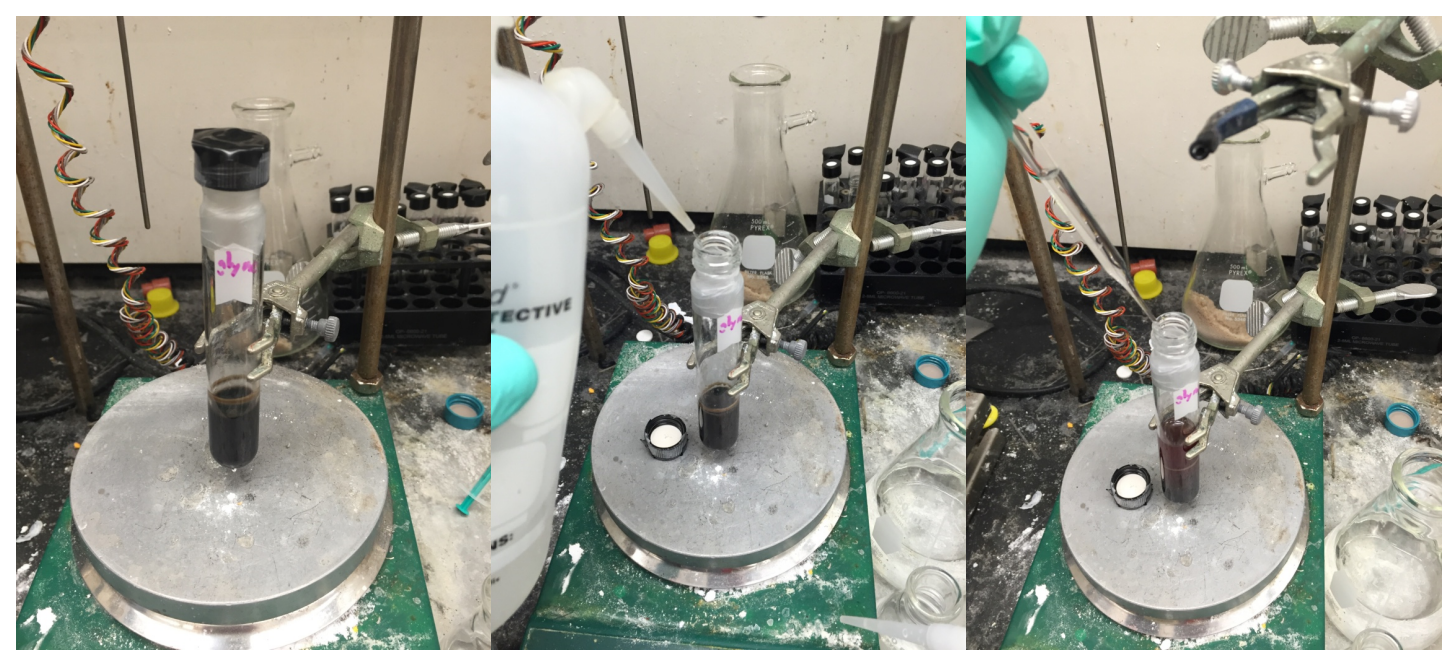

(Left) Reaction with $\mathrm{NiCl}_{2} \bullet$ glyme after $12 \mathrm{hr}$. A black color is often observed but is not imperative to the success of the reaction. (Center) Dilution with $\mathrm{Et}_{2} \mathrm{O}$. (Right) Slow addition of $1 \mathrm{M} \mathrm{HCl}$ (aq). 


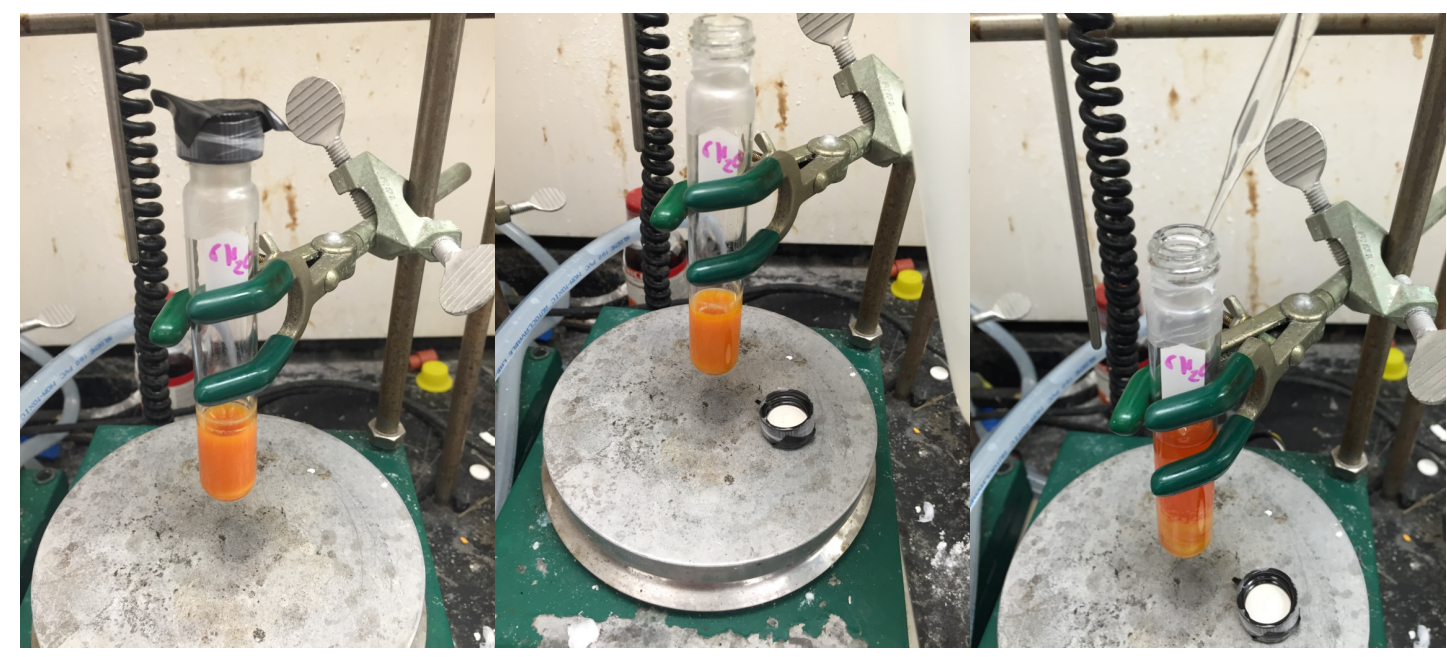

(All) As above with $\mathrm{NiCl}_{2} \bullet 6 \mathrm{H}_{2} \mathrm{O}$.

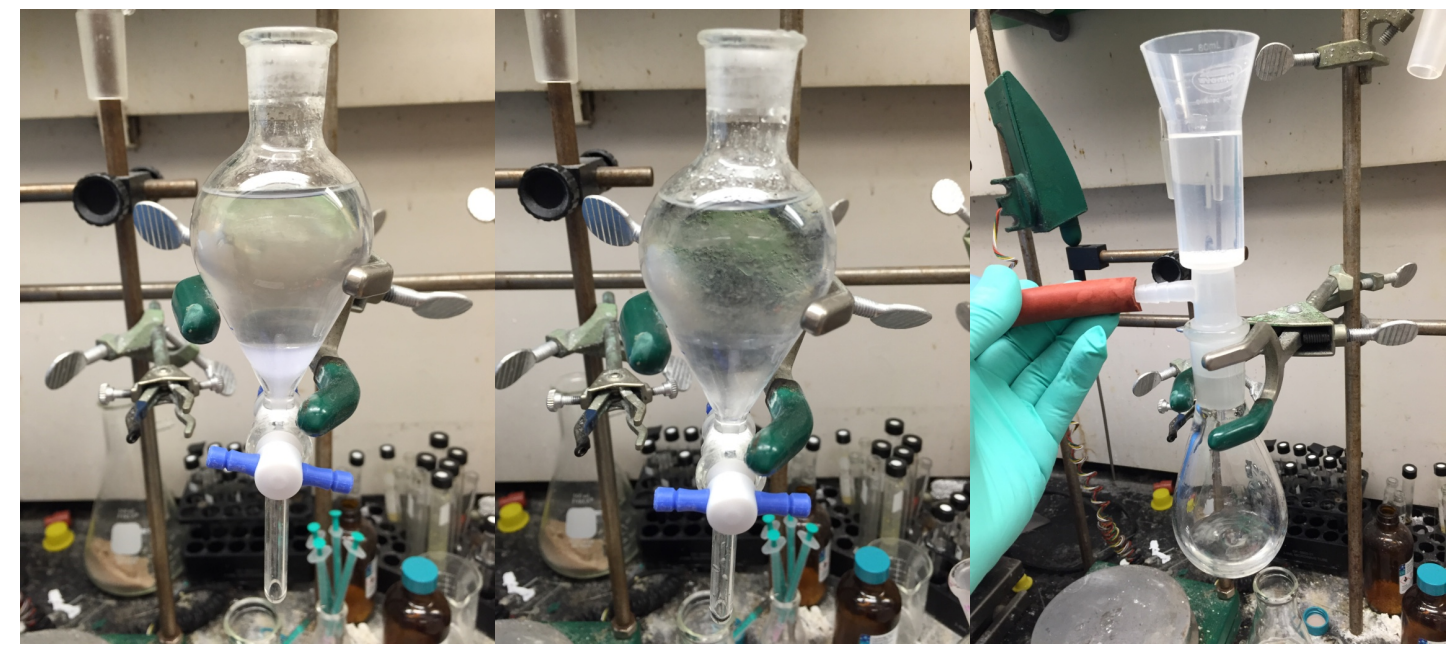

(Left) After $1 \mathrm{M} \mathrm{HCl}(\mathrm{aq})$ wash. (Center) After brine wash. (Right) Filtering the drying agent.

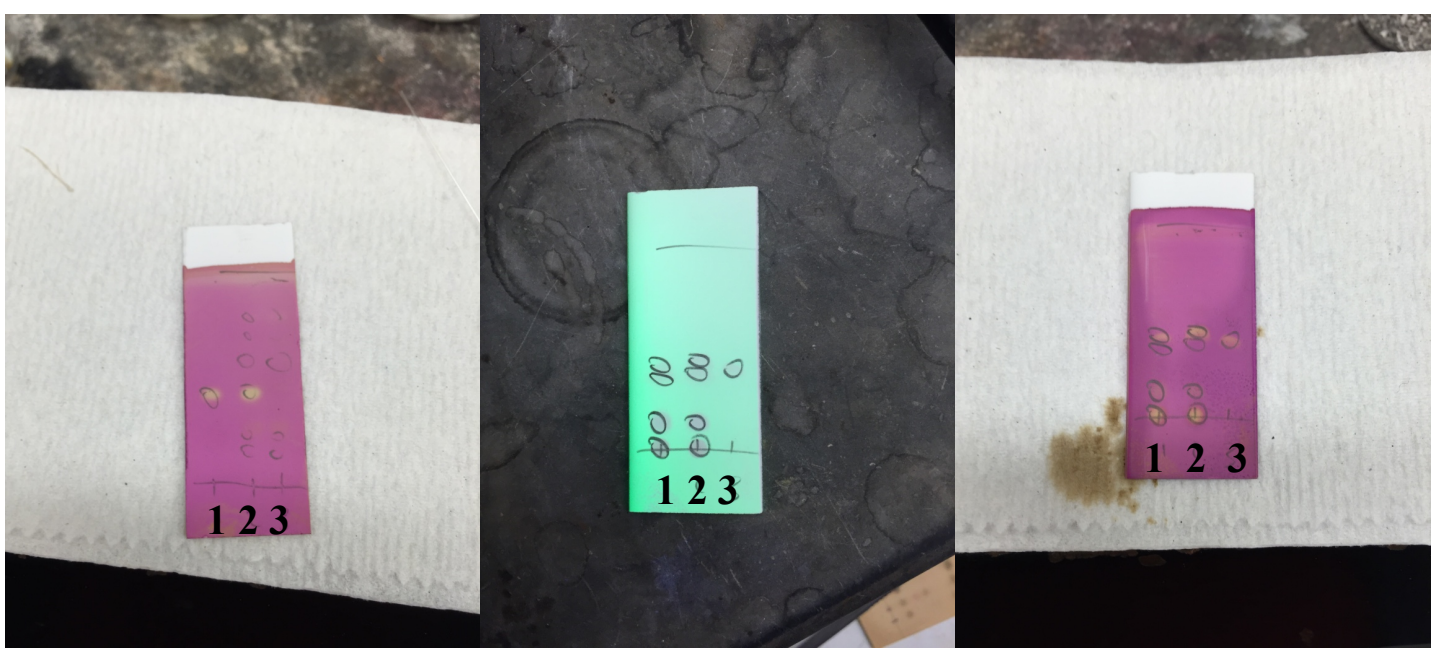

(Left) TLC (4:1 hexanes:EtOAc). Lane 1: 1,3-dioxoisoindolin-2-yl 2-ethylhexanoate; Lane 2: Co-spot; Lane 3: Reaction mixture (Center and Right) TLC (9:1 hexanes:DCM) Lane 1: Reaction mixture; Lane 2: Co-spot; Lane 3: Authentic sample of 1-(heptan-3-yl)-3-methoxybenzene. 


\section{Gram-scale Procedure for the Ni-catalyzed cross-coupling (Heptan-3-ylbenzene).}

The gram-scale coupling procedure is modified from General Procedure B. A threeneck $250 \mathrm{~mL}$ round-bottomed flask was charged with $\mathrm{NiCl}_{2} \cdot$ glyme $(20 \mathrm{~mol} \%)$ and di- $t$ Bubipy (40 mol \%). The flask was fitted with three septa, evacuated by a needle attached to a vacuum line, and placed under positive pressure of argon from a balloon. Reactions were run with a 3:2 ratio of THF:DMF. The volume of DMF $(30.0 \mathrm{~mL})$ used was calculated based on the titre of the THF solution of the arylzinc reagent. Approximately $20 \mathrm{~mL}$ of the volume of DMF was added to the flask containing $\mathrm{NiCl}_{2} \cdot$ glyme and di-tBubipy. The remaining $10 \mathrm{~mL}$ of DMF was used to transfer 1,3dioxoisoindolin-2-yl 2-ethylhexanoate (1.00 g, $3.5 \mathrm{mmol}, 1$ equiv.) to the reaction flask quantitatively (three rinses). The mixture was stirred for 2 minutes at $\mathrm{rt}$. The flask was then placed in a water bath at ambient laboratory temperature. The $\mathrm{PhZnCl} \cdot \mathrm{LiCl}$ in THF (45.1 mL, 3.0 equiv., $0.23 \mathrm{M})$ was added in one portion over the course of approximately 30 seconds. The flask was removed from the water bath, and the mixture was stirred for $16 \mathrm{~h}$ at $\mathrm{rt}$ under positive pressure of argon from a balloon. The mixture was then slowly quenched with $1 \mathrm{M} \mathrm{HCl}$ (aq) and stirred until clear, diluted with $\mathrm{Et}_{2} \mathrm{O}$, and transferred to a separatory funnel. The organic layer was washed with $\mathrm{H}_{2} \mathrm{O}(3 \mathrm{x})$ and brine, dried over anhydrous $\mathrm{MgSO}_{4}$, and concentrated under reduced pressure. The crude material was purified by silica gel column chromatography (pentanes) to yield $483 \mathrm{mg}$ (79\%) of heptan-3-ylbenzene.

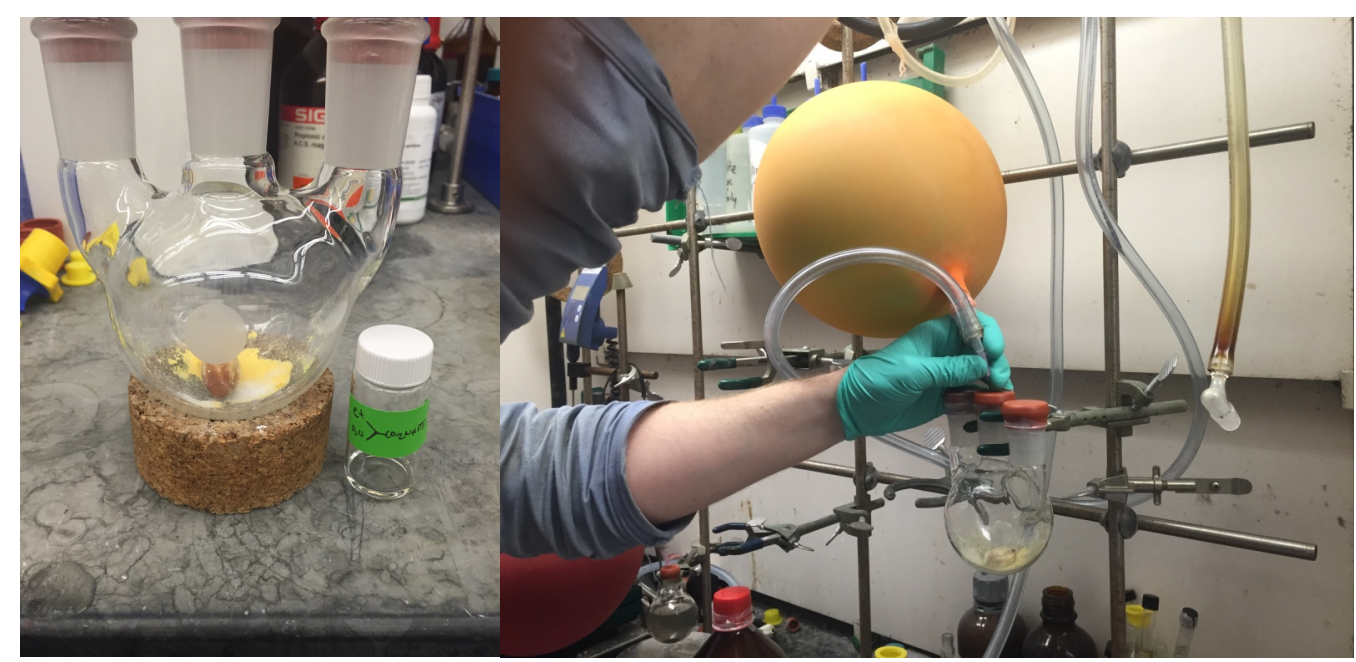

(Left) Reaction flask containing $\mathrm{NiCl}_{2} \cdot$ glyme and di-tBubipy and vial of NHPI-ester. (Right) Evacuation of reaction flask and backfilling with Ar balloon. 


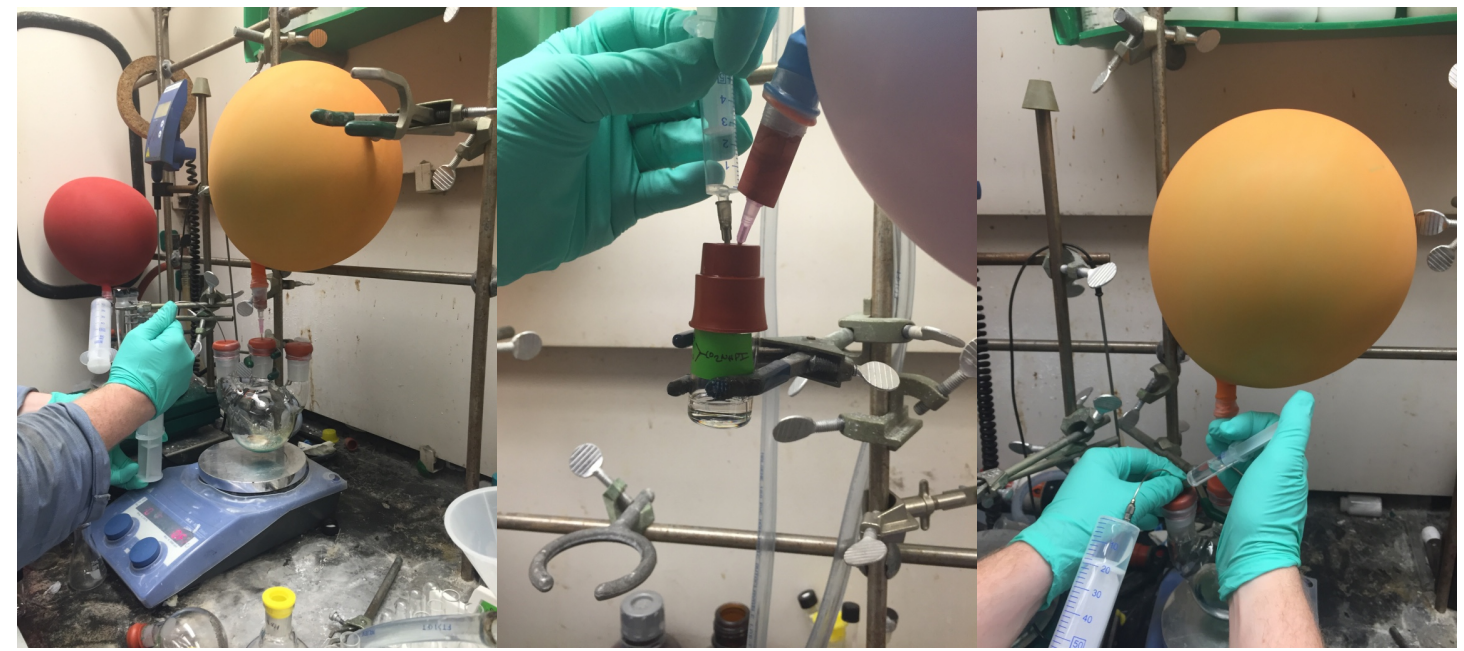

(Left) Addition of DMF to reaction flask. (Center) A solution of 1,3-dioxoisoindolin-2-yl 2ethylhexanoate in DMF (Right) Adding the solution of redox-active ester (in DMF) to the reaction flask.

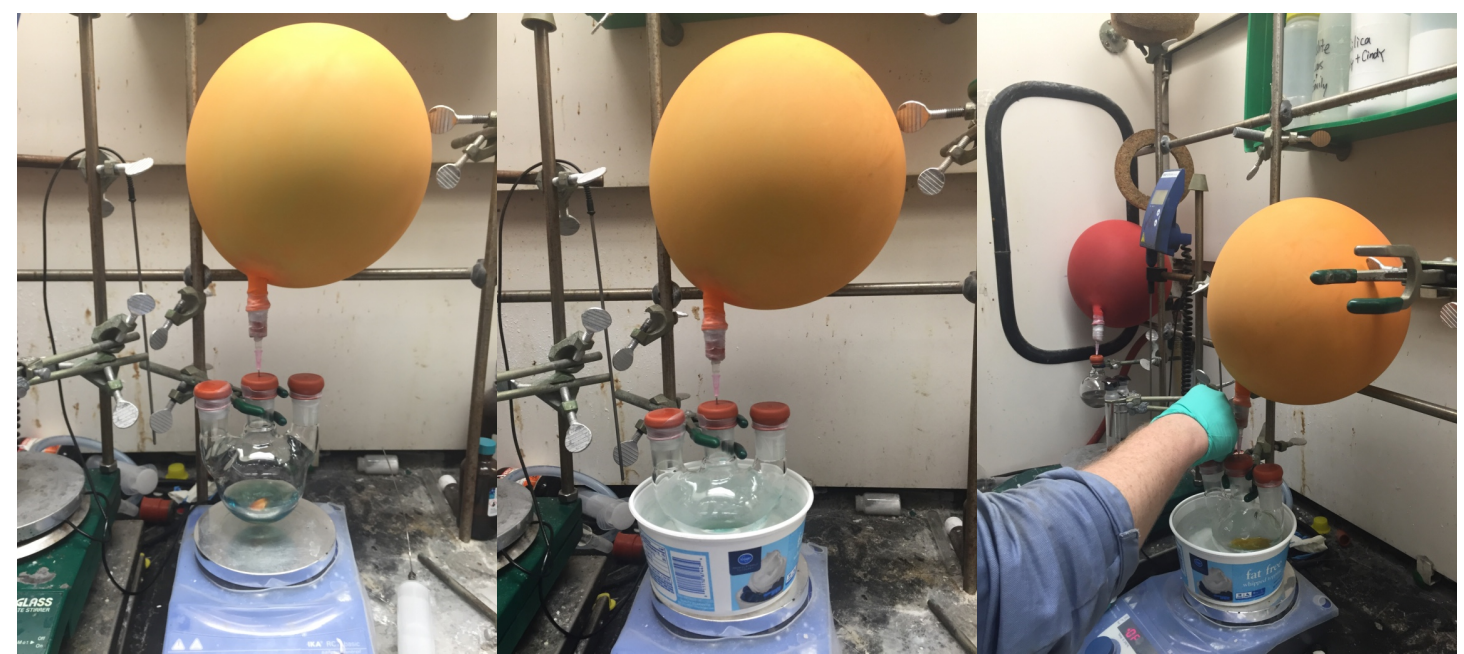

(Left) Reaction flask after addition of redox-active ester. (Center) Reaction flask placed in water bath. (Right) Addition of $\mathrm{PhZnCl} \cdot \mathrm{LiCl}$ in THF.

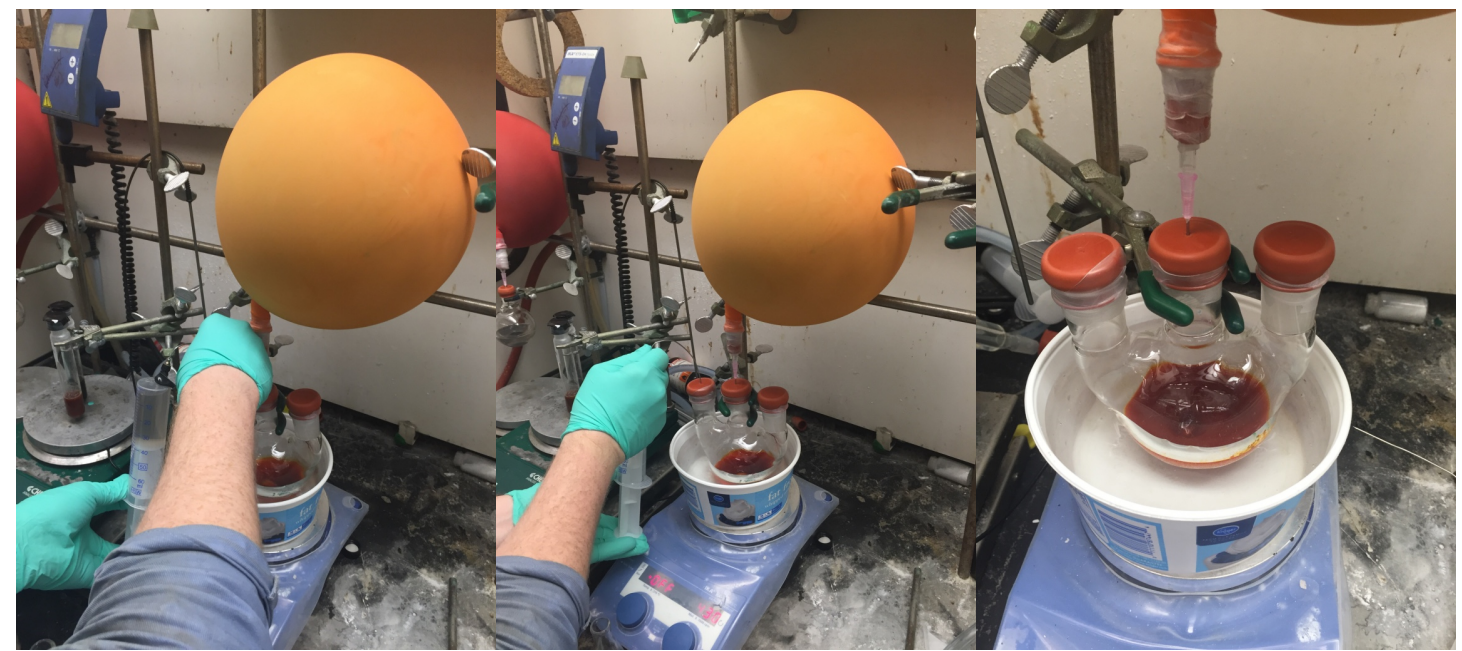

(Left and Center) Progression of addition of $\mathrm{PhZnCl} \cdot \mathrm{LiCl}$ in THF (Right) After addition of $\mathrm{PhZnCl} \cdot \mathrm{LiCl}$ in THF. 


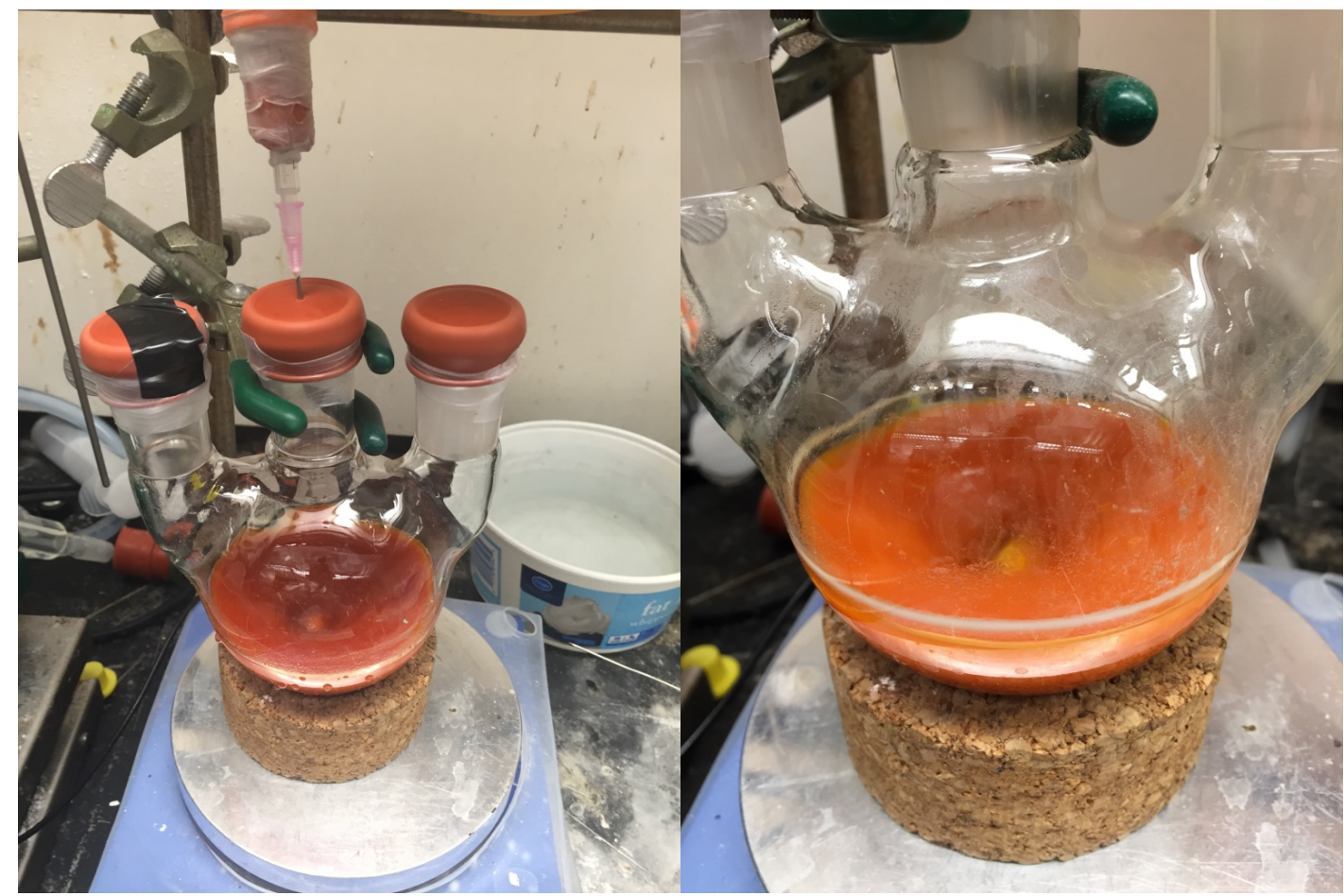

(Left) Removal of flask from water bath to stir overnight. (Right) Reaction mixture after $16 \mathrm{~h}$.

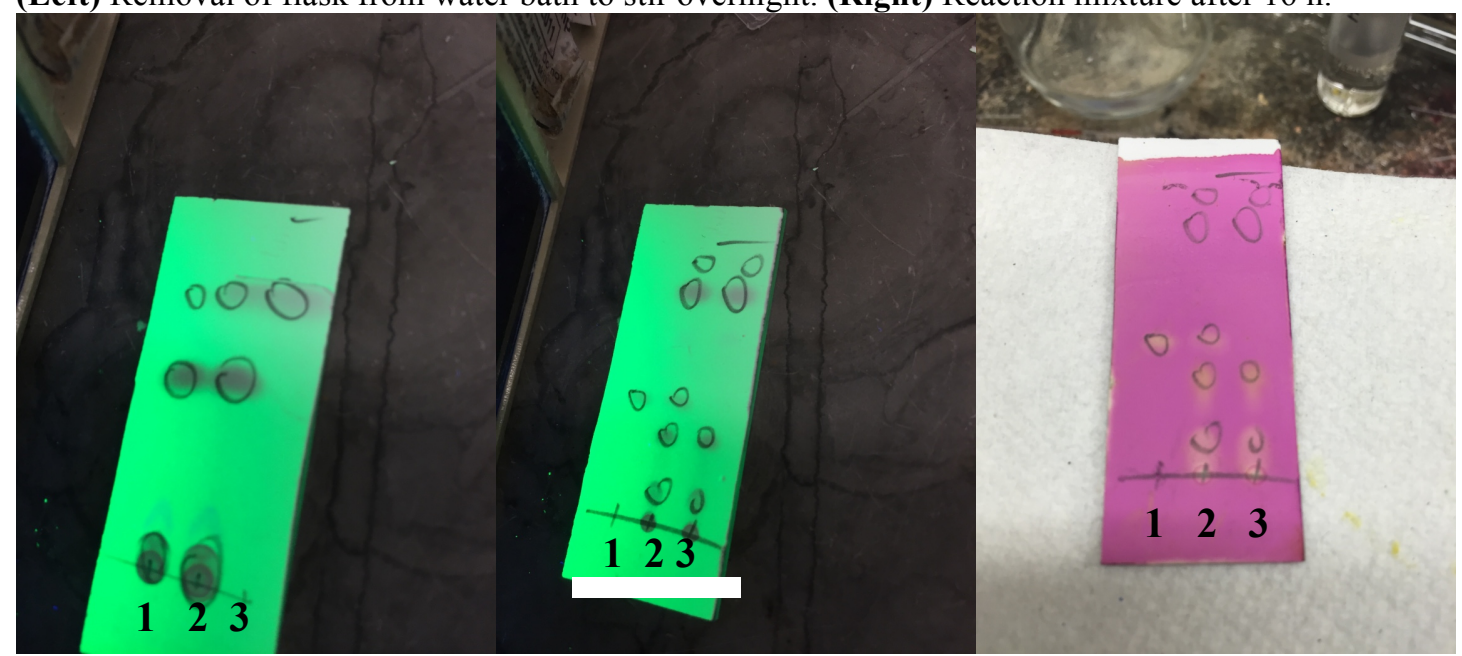

(Left) TLC (hexanes). Lane 1: Reaction mixture; Lane 2: Co-spot; Lane 3: Pure heptan-3-ylbenzene (Center) TLC (4:1 hexanes:EtOAc). Lane 1: 1,3-dioxoisoindolin-2-yl 2-ethylhexanoate; Lane 2: Cospot; Lane 3: Reaction mixture (Right) As center with $\mathrm{KMnO}_{4}$ visualization. 


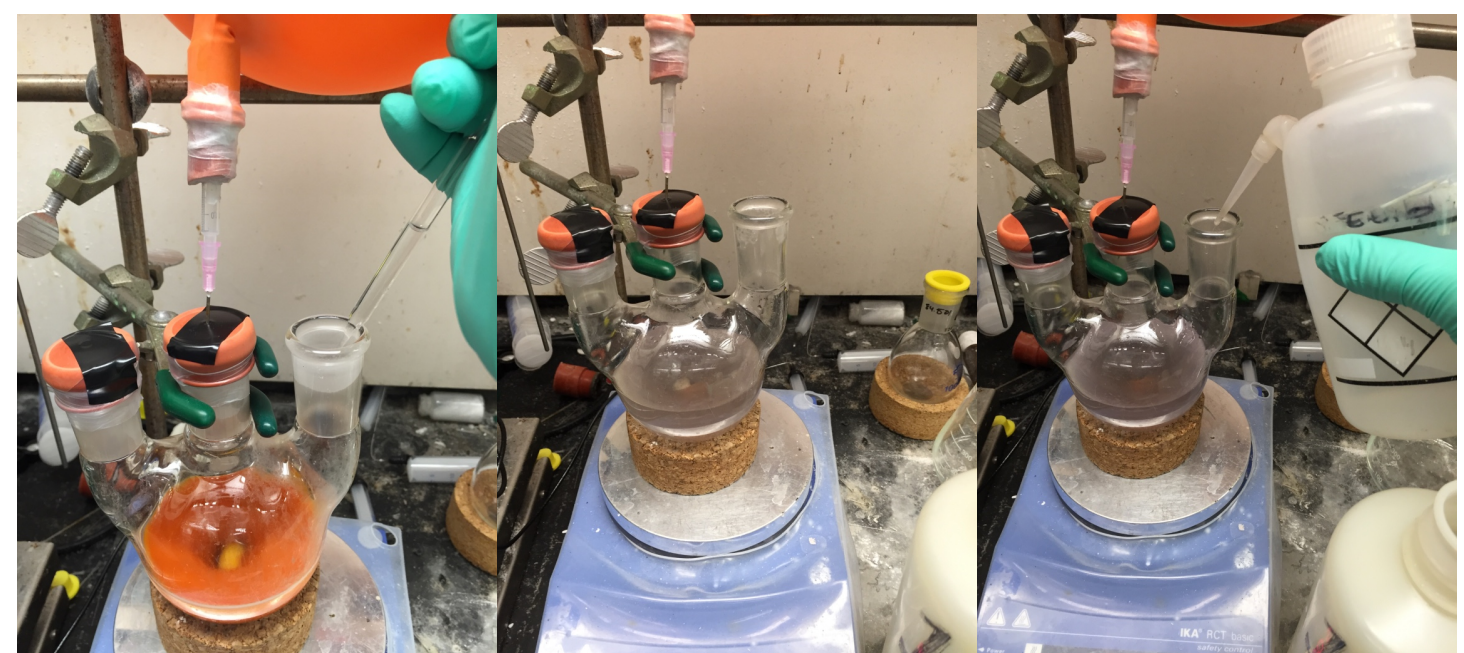

(Left) Quench with 1M HCl. (Center) After quench. (Right) Dilution with diethyl ether.

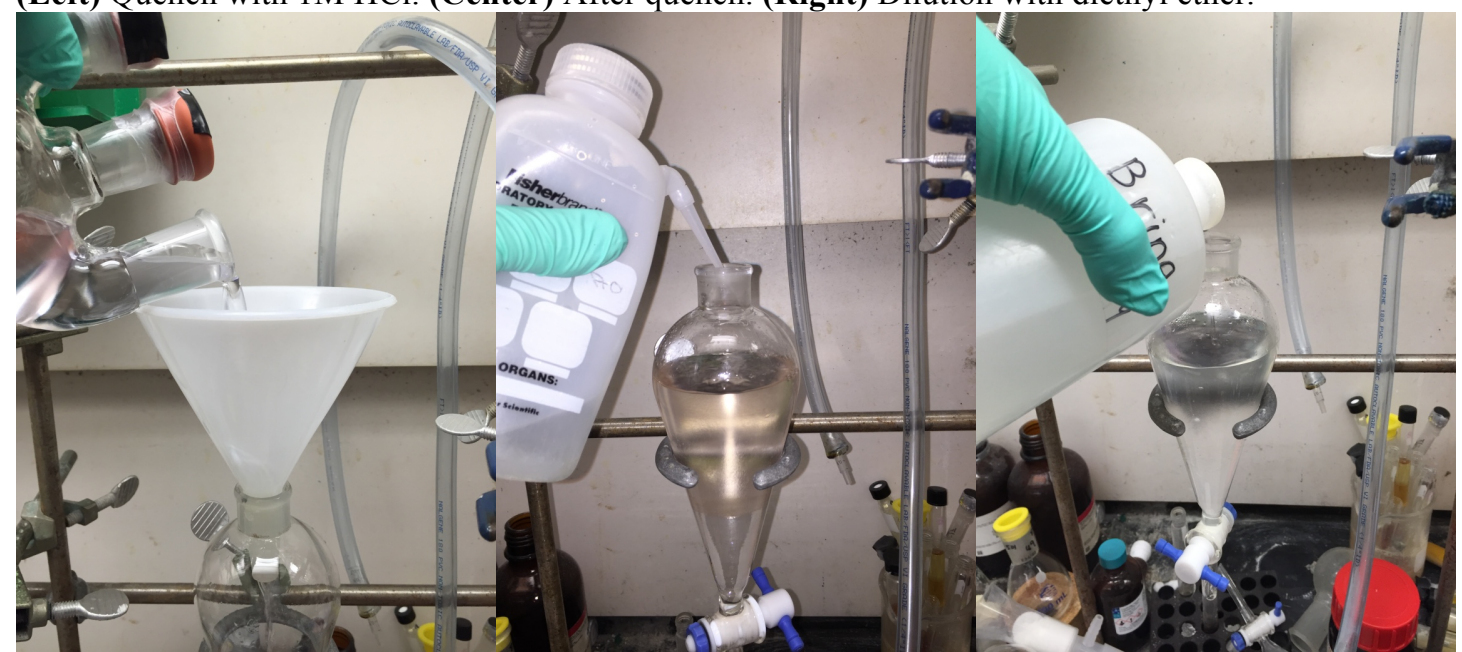

(Left) Transfer to separatory funnel. (Center) Addition of water for wash. (Right) Brine wash.

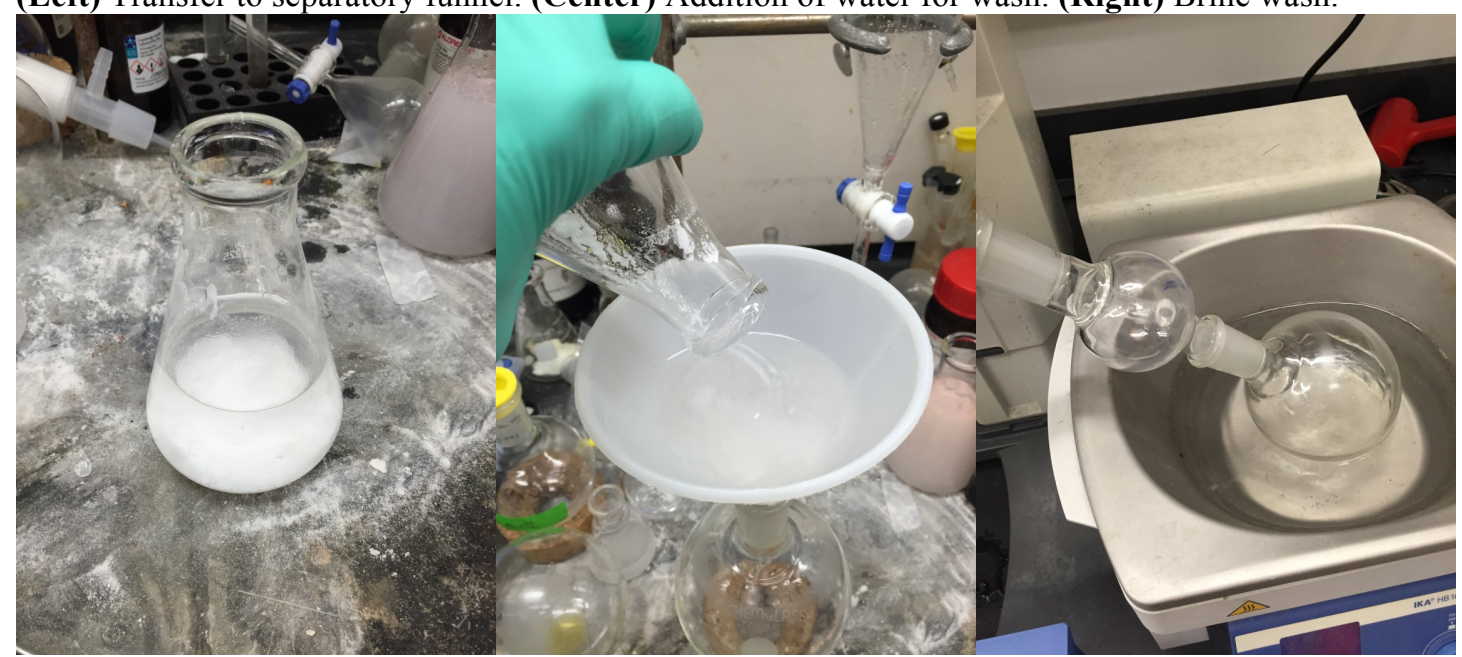

(Left) Drying over $\mathrm{MgSO}_{4}$. (Center) Filtration of drying agent. (Right) Concentration of organic layer. 


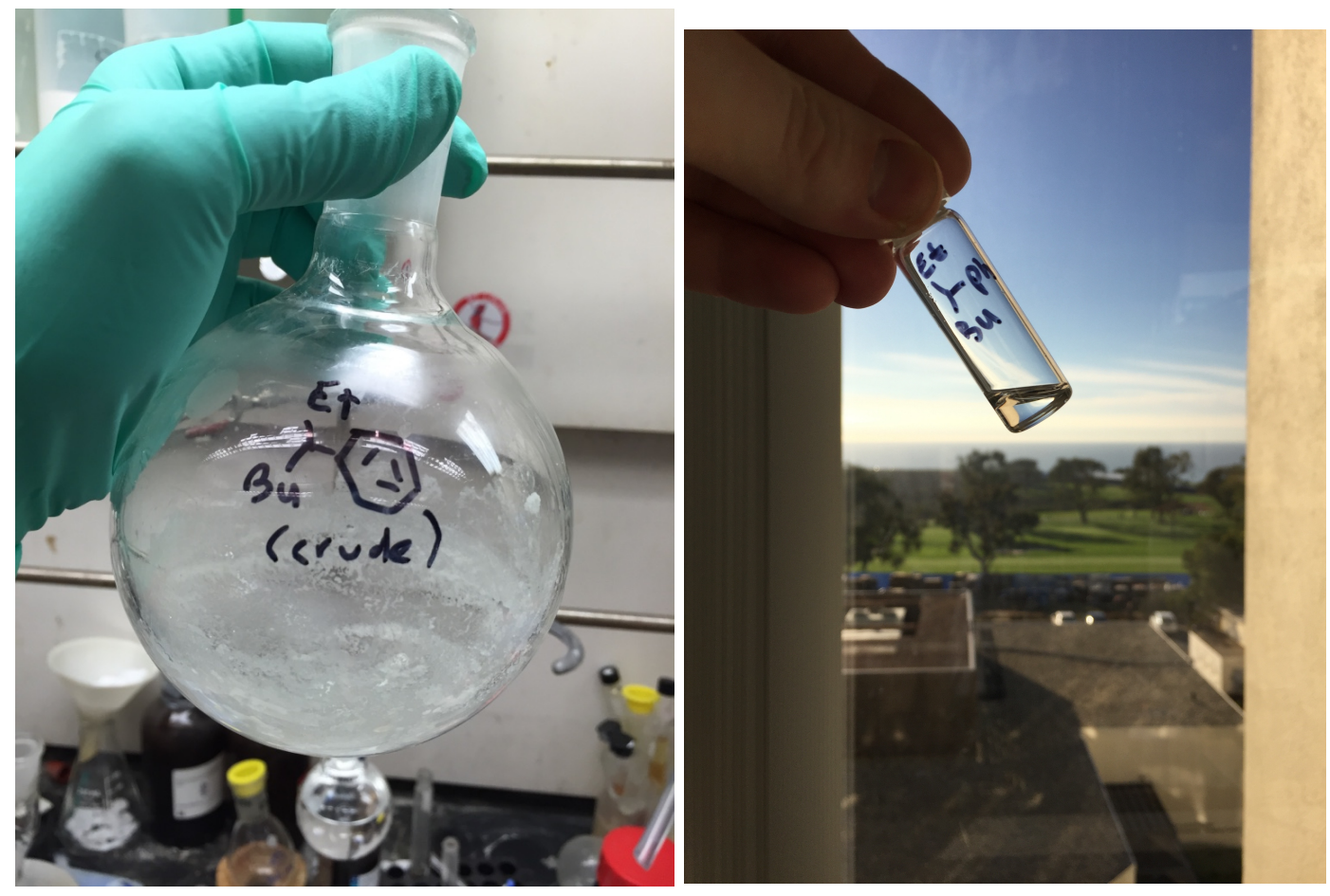

(Left) Crude product. (Right) Pure product after column chromatography.

\section{Procedures and characterization data}<smiles>CCC(Br)c1ccccc1</smiles>

\section{Heptan-3-ylbenzene}

From $\mathrm{NiCl}_{2} \cdot$ glyme: Following the General Procedure B with 1,3-dioxoisoindolin-2-yl 2-ethylhexanoate $(0.25 \mathrm{mmol})$ and $\mathrm{PhZnCl} \cdot \mathrm{LiCl}(0.17 \mathrm{M}$ in THF). Column chromatography with pentane afforded $46 \mathrm{mg}(92 \%)$ of the title compound 3.

From $\mathrm{NiCl}_{2} \cdot$ glyme [gram-scale]: $483 \mathrm{mg}(79 \%)$

From $\mathrm{NiCl}_{2} \cdot 6 \mathrm{H}_{2} \mathrm{O}$ : Following the General Procedure B with 1,3-dioxoisoindolin-2-yl 2-ethylhexanoate $(0.25 \mathrm{mmol})$ and $\mathrm{PhZnCl} \cdot \operatorname{LiCl}(0.17 \mathrm{M}$ in THF). Column chromatography with pentane afforded $47 \mathrm{mg}$ (93\%) of the title compound 3 .

Physical State: colorless oil.

$\boldsymbol{R}_{\boldsymbol{f}}=0.76$ (hexanes).

${ }^{1}$ H NMR (600 MHz, $\left.\mathbf{C D C l}_{3}\right): \delta 7.28(\mathrm{t}, J=7.6 \mathrm{~Hz}, 2 \mathrm{H}), 7.22-7.15(\mathrm{~m}, 1 \mathrm{H}), 7.15-$ $7.07(\mathrm{~m}, 2 \mathrm{H}), 2.39(\mathrm{tt}, J=9.5,5.3 \mathrm{~Hz}, 1 \mathrm{H}), 1.75-1.59(\mathrm{~m}, 2 \mathrm{H}), 1.59-1.46(\mathrm{~m}, 2 \mathrm{H})$, $1.33-1.00(\mathrm{~m}, 4 \mathrm{H}), 0.83(\mathrm{t}, J=7.3 \mathrm{~Hz}, 3 \mathrm{H})$, and $0.77(\mathrm{t}, J=7.4 \mathrm{~Hz}, 3 \mathrm{H})$. 
${ }^{13}$ C NMR (151 MHz, $\left.\mathbf{C D C l}_{3}\right): \delta 146.5,128.5,128.1,126.1,48.2,36.61,30.2,30.1$, 23.2, 14.4, and 12.6.

GC/MS (m/z (rel int)): $176\left(\mathrm{M}^{+}, 0.16\right), 147(0.18), 119(0.30), 91(1.00)$.<smiles>CCC(CC)c1cccc(OC)c1</smiles>

\section{1-(Heptan-3-yl)-3-methoxybenzene}

From $\mathrm{NiCl}_{2} \cdot$ glyme: Following the General Procedure B with 1,3-dioxoisoindolin-2-yl 2-ethylhexanoate $(0.25 \mathrm{mmol}), 3-\mathrm{OMePhZnCl} \bullet \mathrm{LiCl}(0.21 \mathrm{M}$ in THF), and di-tertbutylbipyridine (0.3 equiv). Purification by PTLC (0.5:99.5 acetone:hexanes) afforded 6 (34 mg, 66\% yield).

From $\mathrm{NiCl}_{2} \cdot 6 \mathrm{H}_{2} \mathrm{O}$ : Following the General Procedure B with 1,3-dioxoisoindolin-2-yl 2-ethylhexanoate $(0.25 \mathrm{mmol})$ and $3-\mathrm{OMePhZnCl} \cdot \mathrm{LiCl}(0.23 \mathrm{M}$ in THF). Purification by PTLC (0.5:99.5 acetone:hexanes) afforded 6 (33 $\mathrm{mg}, 64 \%$ yield).

Physical State: colorless oil.

$\boldsymbol{R}_{\boldsymbol{f}}=0.33(0.5: 99.5$ acetone/hexanes).

${ }^{1}$ H NMR (600 MHz, CDCl $)$ ): $\delta 7.20(\mathrm{t}, J=7.8 \mathrm{~Hz}, 1 \mathrm{H}), 6.82-6.71(\mathrm{~m}, 2 \mathrm{H}), 6.69(\mathrm{~d}$, $J=1.9 \mathrm{~Hz}, 1 \mathrm{H}), 3.81(\mathrm{~s}, 3 \mathrm{H}), 2.36(\mathrm{tt}, J=9.6,5.3 \mathrm{~Hz}, 1 \mathrm{H}), 1.73-1.58(\mathrm{~m}, 2 \mathrm{H}), 1.57$ $-1.49(\mathrm{~m}, 2 \mathrm{H}), 1.39-1.19(\mathrm{~m}, 2 \mathrm{H}), 1.20-1.01(\mathrm{~m}, 2 \mathrm{H}), 0.83(\mathrm{t}, J=7.3 \mathrm{~Hz}, 3 \mathrm{H})$, and $0.77(\mathrm{t}, J=7.4 \mathrm{~Hz}, 3 \mathrm{H})$.

${ }^{13}$ C NMR (151 MHz, $\left.\mathbf{C D C l}_{3}\right): \delta 159.6,148.1,129.1,120.5,113.9,110.7,55.2,48.1$, $36.4,30.0,29.8,23.0,14.2$, and 12.4 .

HRMS (ESI-TOF): calc'd for $\mathrm{C}_{14} \mathrm{H}_{23} \mathrm{O}[\mathrm{M}+\mathrm{H}]^{+} 207.1743$; found 207.1753.<smiles>CCC(CC)c1cccc(C(F)(F)F)c1</smiles>

\section{1-(Heptan-3-yl)-3-(trifluoromethyl)benzene}

From $\mathrm{NiCl}_{2} \cdot$ glyme: Following the General Procedure B with 1,3-dioxoisoindolin-2-yl 2-ethylhexanoate $(0.25 \mathrm{mmol})$ and $3-\mathrm{CF}_{3}-\mathrm{PhZnCl} \cdot \mathrm{LiCl}(0.25 \mathrm{M}$ in THF). Column chromatography with pentane afforded $39 \mathrm{mg}(66 \%)$ of the title compound 7. 
From $\mathrm{NiCl}_{2} \cdot 6 \mathrm{H}_{2} \mathrm{O}$ : Following the General Procedure B with 1,3-dioxoisoindolin-2-yl 2-ethylhexanoate $(0.25 \mathrm{mmol})$ and $3-\mathrm{CF}_{3}-\mathrm{PhZnCl} \cdot \mathrm{LiCl}(0.25 \mathrm{M}$ in THF). Column chromatography with pentane afforded $42 \mathrm{mg}(69 \%)$ of the title compound 7.

Physical State: colorless oil.

$\boldsymbol{R}_{\boldsymbol{f}}=0.79$ (Hexane).

${ }^{1}$ H NMR (400 MHz, $\left.\mathbf{C D C l}_{3}\right): \delta 7.47$ (d, $\left.J=7.8 \mathrm{~Hz}, 1 \mathrm{H}\right), 7.44-7.38$ (m, 2H), 7.34 $(\mathrm{d}, J=7.6 \mathrm{~Hz}, 1 \mathrm{H}), 2.49(\mathrm{~m}, 1 \mathrm{H}), 1.79-1.63(\mathrm{~m}, 2 \mathrm{H}), 1.56(\mathrm{~m}, 2 \mathrm{H}), 1.37-0.99(\mathrm{~m}$, $4 \mathrm{H}), 0.86(\mathrm{t}, J=7.2 \mathrm{~Hz}, 3 \mathrm{H})$, and $0.78(\mathrm{t}, J=7.3 \mathrm{~Hz}, 3 \mathrm{H})$.

${ }^{13}$ C NMR (151 MHz, $\left.\mathbf{C D C l}_{3}\right): \delta$ 146.6, 130.7, 123.00 (q, $\left.J=32.0 \mathrm{~Hz}, 1 \mathrm{C}\right), 128.1$, 124.0 (q, $J=272.4 \mathrm{~Hz}, 1 \mathrm{C}), 124.0$ (q, $J=3.4 \mathrm{~Hz}, 1 \mathrm{C}), 122.2$ (q, $J=4.3 \mathrm{~Hz}, 1 \mathrm{C}), 47.4$, 35.6, 29.3, 29.1, 22.3, 13.5, and 11.6.

${ }^{19}$ F NMR (376 MHz, $\left.\mathrm{CDCl}_{3}\right): \delta-62.73$.

HRMS (APCI): calc'd for $\mathrm{C}_{14} \mathrm{H}_{18} \mathrm{~F}_{3}[\mathrm{M}-\mathrm{H}]^{-} 243.1366$; found 243.1.<smiles>CCC(Br)c1ccc(Cl)cc1</smiles>

\section{1-Chloro-4-(heptan-3-yl)benzene}

From $\mathrm{NiCl}_{2} \cdot$ glyme: Following the General Procedure B with 1,3-dioxoisoindolin-2-yl 2-ethylhexanoate $(0.25 \mathrm{mmol})$ and $4-\mathrm{Cl}-\mathrm{PhZnCl} \cdot \mathrm{LiCl}(0.21 \mathrm{M}$ in THF). Column chromatography with pentane afforded $30 \mathrm{mg}$ (71\%) of the title compound 8 .

From $\mathrm{NiCl}_{2} \cdot 6 \mathrm{H}_{2} \mathrm{O}$ : Following the General Procedure B with 1,3-dioxoisoindolin-2-yl 2-ethylhexanoate $(0.25 \mathrm{mmol})$ and $4-\mathrm{Cl}-\mathrm{PhZnCl} \cdot \mathrm{LiCl}(0.21 \mathrm{M}$ in THF). Column chromatography with pentane afforded $41 \mathrm{mg}(77 \%)$ of the title compound 8 .

Physical State: colorless oil.

$\boldsymbol{R}_{\boldsymbol{f}}=0.74$ (hexanes).

${ }^{1}$ H NMR (600 MHz, $\left.\mathbf{C D C l}_{3}\right): \delta 7.31-7.20(\mathrm{~m}, 2 \mathrm{H}), 7.14-6.96(\mathrm{~m}, 2 \mathrm{H}), 2.40(\mathrm{tt}, J$ $=9.6,5.2 \mathrm{~Hz}, 1 \mathrm{H}), 1.75-1.61(\mathrm{~m}, 2 \mathrm{H}), 1.58-1.46(\mathrm{~m}, 2 \mathrm{H}), 1.36-1.03(\mathrm{~m}, 4 \mathrm{H})$, $0.86(\mathrm{t}, J=7.4 \mathrm{~Hz}, 3 \mathrm{H})$, and $0.78(\mathrm{t}, J=7.4 \mathrm{~Hz}, 3 \mathrm{H})$.

${ }^{13}$ C NMR (151 MHz, $\left.\mathbf{C D C l}_{3}\right): \delta 144.1,130.8,128.6,127.8,46.9,35.8,29.3,29.2$, $22.3,13.6$, and 11.7.

HRMS (APCI): calc'd for $\mathrm{C}_{13} \mathrm{H}_{19} \mathrm{Cl}$ [M] 210.1175; found 210.1162. 
$\underbrace{\mathrm{OMe}}_{B u}$

9

\section{1-(Heptan-3-yl)-2-methoxybenzene}

From $\mathrm{NiCl}_{2} \cdot$ glyme: Following the General Procedure B with 4,5,6,7-tetrachloro-1,3dioxoisoindolin-2-yl 2-ethylhexanoate $(0.25 \mathrm{mmol})$ and 3 -OMePhZnCl$\bullet \mathrm{LiCl}(0.23$ M) at $60^{\circ} \mathrm{C}$. Purification by column chromatography with gradient elution (hexanes to $19: 1$ hexanes:DCM) afforded $9(27 \mathrm{mg}, 52 \%$ yield).

Physical State: colorless oil.

$\boldsymbol{R}_{\boldsymbol{f}}=0.38(5: 95 \mathrm{DCM} /$ hexanes $)$.

${ }^{1}$ H NMR (400 MHz, CDCl $)$ ): $\delta 7.21-7.09$ (m, 2H), $6.92(\mathrm{t}, J=7.4 \mathrm{~Hz}, 1 \mathrm{H}), 6.86(\mathrm{~d}$, $J=8.1 \mathrm{~Hz}, 1 \mathrm{H}), 3.80(\mathrm{~s}, 3 \mathrm{H}), 3.00(\mathrm{ddd}, J=14.5,8.7,5.9 \mathrm{~Hz}, 1 \mathrm{H}), 1.72-1.48(\mathrm{~m}$, $4 \mathrm{H}), 1.42-1.02(\mathrm{~m}, 4 \mathrm{H}), 0.84(\mathrm{t}, J=7.2 \mathrm{~Hz}, 3 \mathrm{H})$, and $0.77(\mathrm{t}, J=7.4 \mathrm{~Hz}, 3 \mathrm{H})$.

${ }^{13}$ C NMR (151 MHz, $\left.\mathbf{C D C l}_{3}\right): \delta 157.9,134.6,127.6,126.4,120.6,110.7,55.6,39.2$, $35.2,29.9,28.6,23.0,14.2$, and 12.2.

HRMS (ESI-TOF): calc'd for $\mathrm{C}_{14} \mathrm{H}_{23} \mathrm{O}\left[\mathrm{M}+\mathrm{H}^{+}\right]$207.1743; found 207.1739.<smiles>CCC(CC)c1ccc(OC)cc1</smiles>

\section{1-(Heptan-3-yl)-3-methoxybenzene}

From $\mathrm{NiCl}_{2} \cdot g l y m e$ : Following the General Procedure B with 1,3-dioxoisoindolin-2-yl 2-ethylhexanoate $(0.25 \mathrm{mmol})$ and $4-\mathrm{OMePhZnCl} \bullet \mathrm{LiCl}(0.20 \mathrm{M})$. Purification by column chromatography with gradient elution (hexanes to 9:1 hexanes: $\mathrm{CH}_{2} \mathrm{Cl}_{2}$ ) afforded 10 (35 mg, 68\% yield).

From $\mathrm{NiCl}_{2} \cdot 6 \mathrm{H}_{2} \mathrm{O}$ : Following the General Procedure B with 1,3-dioxoisoindolin-2-yl 2-ethylhexanoate $(0.25 \mathrm{mmol})$ and $4-\mathrm{OMePhZnCl} \bullet \mathrm{LiCl}(0.20 \mathrm{M})$. Purification by column chromatography with gradient elution (hexanes to 9:1 hexanes: $\mathrm{CH}_{2} \mathrm{Cl}_{2}$ ) afforded 10 (42 mg, 81\% yield).

Physical State: colorless oil.

$\boldsymbol{R}_{\boldsymbol{f}}=0.25\left(9: 1\right.$ hexanes: $\left.\mathrm{CH}_{2} \mathrm{Cl}_{2}\right)$.

${ }^{1}$ H NMR (600 MHz, $\left.\mathbf{C D C l}_{3}\right): \delta 7.08-7.02(\mathrm{~m}, 2 \mathrm{H}), 6.90-6.80(\mathrm{~m}, 2 \mathrm{H}), 3.79(\mathrm{~s}$, $3 \mathrm{H}), 2.33(\mathrm{tt}, J=9.3,5.3 \mathrm{~Hz}, 1 \mathrm{H}), 1.69-1.58(\mathrm{~m}, 2 \mathrm{H}), 1.53-1.45(\mathrm{~m}, 2 \mathrm{H}), 1.33-$ $1.04(\mathrm{~m}, 4 \mathrm{H}), 0.83(\mathrm{t}, J=7.3 \mathrm{~Hz}, 3 \mathrm{H})$, and $0.75(\mathrm{t}, J=7.4 \mathrm{~Hz}, 3 \mathrm{H})$. 
${ }^{13}$ C NMR (151 MHz, $\left.\mathbf{C D C l}_{3}\right): \delta 157.8,138.3,128.7,113.6,55.3,47.1,36.6,30.0$ (2C), 23.0, 14.2, and 12.3.

HRMS (ESI-TOF): calc'd for $\mathrm{C}_{14} \mathrm{H}_{22} \mathrm{O}\left[\mathrm{MH}^{+}\right]$207.1743; found 207.1750.<smiles>CCC(Br)c1ccc(C#N)cc1</smiles>

\section{4-(heptan-3-yl)benzonitrile}

From $\mathrm{NiCl}_{2} \cdot$ glyme: Following the General Procedure B with 1f (4,5,6,7-tetrachloro1,3-dioxoisoindolin-2-yl 2-ethylhexanoate, $0.25 \mathrm{mmol}$ ) and $4-\mathrm{CN}-\mathrm{PhZnCl} \cdot \mathrm{LiCl}$ in THF. This organozinc reagent could not be titrated due to its dark color (see picture below), so quantitative yield of the reagent was assumed ( $3 \mathrm{~mL}, 0.25 \mathrm{M})$. Purification by column chromatography (9:1 hexanes:EtOAc) and PTLC in the same solvet system afforded 11 (27 mg, 54\% yield).

Physical State: colorless oil.

$\boldsymbol{R}_{\boldsymbol{f}}=0.71$ (4:1 hexanes:EtOAc).

${ }^{1} \mathrm{H}$ NMR (600 MHz, $\left.\mathrm{CDCl}_{3}\right) \delta 7.59-7.55(\mathrm{~m}, 2 \mathrm{H}), 7.25-7.22(\mathrm{~m}, 2 \mathrm{H}), 2.46(\mathrm{tt}, J=$ 9.3, 5.3 Hz, 1H), $1.74-1.61(\mathrm{~m}, 2 \mathrm{H}), 1.57-1.48(\mathrm{~m}, 2 \mathrm{H}), 1.32-1.18(\mathrm{~m}, 2 \mathrm{H}), 1.13$ (dddt, $J=13.1,10.3,8.7,5.8 \mathrm{~Hz}, 1 \mathrm{H}), 1.08-0.98(\mathrm{~m}, 1 \mathrm{H}), 0.82(\mathrm{t}, J=7.3 \mathrm{~Hz}, 3 \mathrm{H})$, and $0.75(\mathrm{t}, J=7.4 \mathrm{~Hz}, 3 \mathrm{H})$.

${ }^{13} \mathrm{C}$ NMR $\left(151 \mathrm{MHz}, \mathrm{CDCl}_{3}\right) \delta 152.1,132.2,128.7,119.4,109.8,48.3,36.1,29.9$, 29.6, 22.8, 14.1, and 12.2.

HRMS (ESI-TOF): calc'd for $\mathrm{C}_{14} \mathrm{H}_{20}\left[\mathrm{MH}^{+}\right]$202.1590; found 202.1590. 


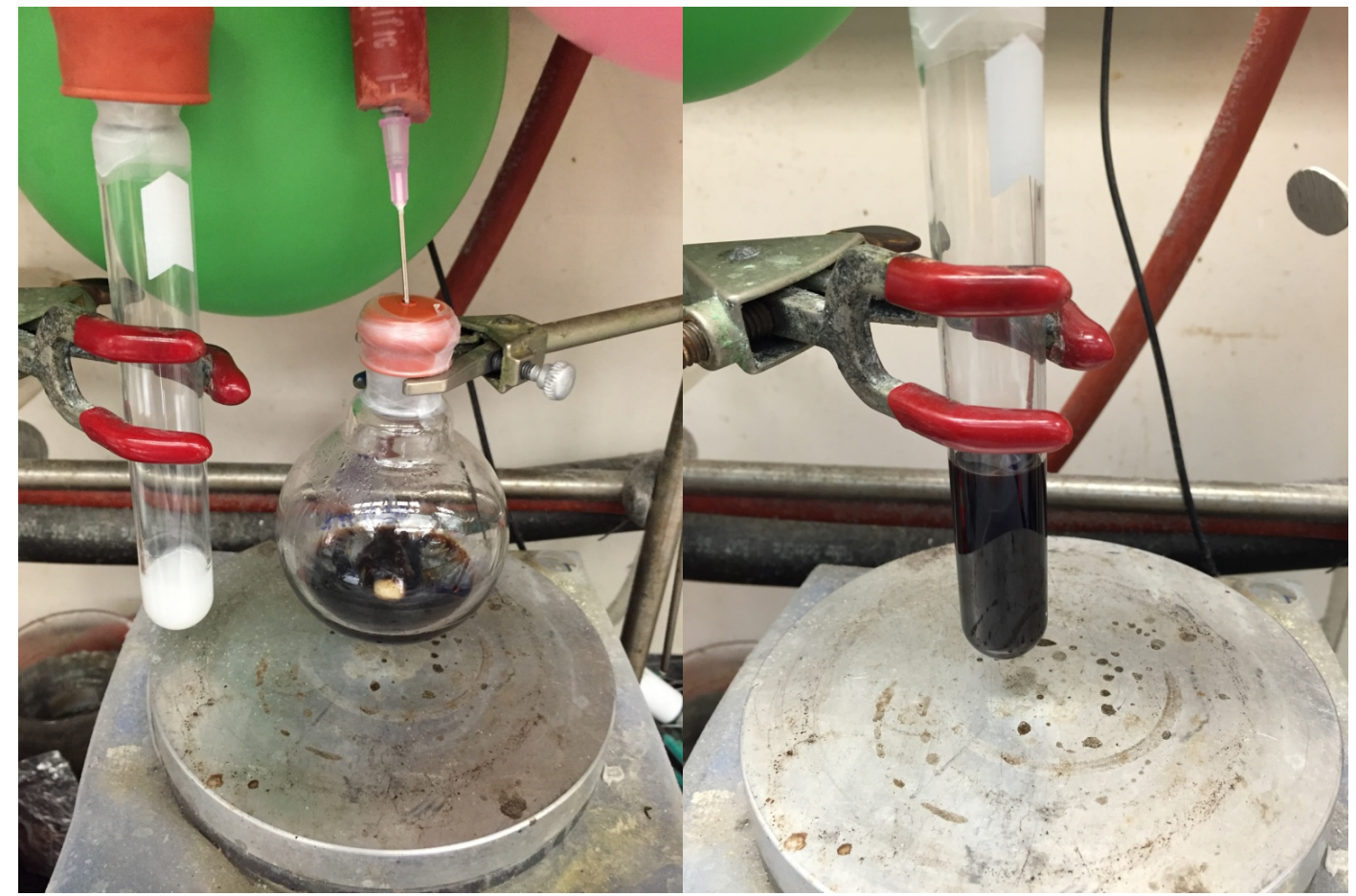

(Left) $\mathrm{ZnCl}_{2}$ solution in THF (left) and $4-\mathrm{CNMgBr} \cdot \mathrm{LiCl}$ (right). (Right) $4-\mathrm{CNZnCl} \cdot \mathrm{LiCl}$ in THF.

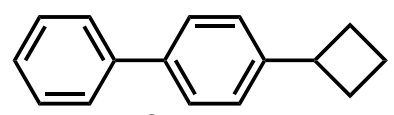

12

\section{4-Cyclobutyl-1,1'-biphenyl}

From $\mathrm{NiCl}_{2} \cdot$ glyme: Following the General Procedure B with 1,3-dioxoisoindolin-2-yl cyclobutylcarboxylate $(0.25 \mathrm{mmol})$ and $4-\mathrm{Ph}-\mathrm{PhZnCl} \cdot \mathrm{LiCl}$ complex $(0.22 \mathrm{M}$ in THF). PTLC (hexanes) afforded $20.3 \mathrm{mg}$ (65\%) of the title compound 12.

Physical State: white solid; mp: $28^{\circ} \mathrm{C}$.

$\boldsymbol{R}_{\boldsymbol{f}}=0.30$ (hexanes).

${ }^{1}$ H NMR (600 MHz, $\left.\mathbf{C D C l}_{3}\right): \delta 7.60$ - 7.57 (m, 2H), 7.55 - $7.52(\mathrm{~m}, 2 \mathrm{H}), 7.45-7.41$ (m, 2H), $7.34-7.32$ (m, 1H), $7.32-7.28$ (m, 2H), $3.64-3.55(\mathrm{~m}, 1 \mathrm{H}), 2.42-2.32$ (m, 2H), $2.25-2.14(\mathrm{~m}, 2 \mathrm{H}), 2.10-1.99(\mathrm{~m}, 1 \mathrm{H})$, and $1.93-1.84(\mathrm{~m}, 1 \mathrm{H})$.

${ }^{13}$ C NMR (150 MHz, $\left.\mathbf{C D C l}_{3}\right): \delta 145.5,141.3,138.8,128.8,127.2,127.1,127.1$, $126.9,40.2,30.0$, and 18.5.

HRMS (ESI-TOF): calc'd for $\mathrm{C}_{16} \mathrm{H}_{17}\left[(\mathrm{M}+\mathrm{H})^{+}\right]$209.1325; found 209.1326. 


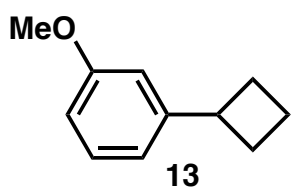

\section{1-Cyclobutyl-3-methoxybenzene}

From $\mathrm{NiCl}_{2} \cdot$ glyme: Following the General Procedure B with 1,3-dioxoisoindolin-2-yl cyclobutanecarboxylate $(0.25 \mathrm{mmol})$ and $3-\mathrm{MeOPhZnCl} \cdot \mathrm{LiCl}(0.23 \mathrm{M}$ in $\mathrm{THF})$. Column chromatography with hexanes afforded $25 \mathrm{mg}(62 \%)$ of the title compound 13.

From $\mathrm{NiCl}_{2} \cdot 6 \mathrm{H}_{2} \mathrm{O}$ : Following the General Procedure B with 1,3-dioxoisoindolin-2-yl cyclobutanecarboxylate $(0.25 \mathrm{mmol})$ and $3-\mathrm{OMePhZnCl} \cdot \mathrm{LiCl}(0.23 \mathrm{M}$ in $\mathrm{THF})$. Column chromatography with hexane afforded $26 \mathrm{mg}(64 \%)$ of the title compound 13.

Physical State: colorless oil.

$\boldsymbol{R}_{\boldsymbol{f}}=0.34$ (hexanes).

${ }^{1}$ H NMR (600 MHz, CDCl $)$ ): $\delta 7.23(\mathrm{t}, J=7.9 \mathrm{~Hz}, 1 \mathrm{H}), 6.83(\mathrm{~m}, 1 \mathrm{H}), 6.78(\mathrm{t}, J=1.9$ $\mathrm{Hz}, 1 \mathrm{H}), 6.73$ (ddd, $J=7.9,2.9,0.9 \mathrm{~Hz}, 1 \mathrm{H}), 3.82$ (s, 3H), $3.58-3.50$ (m, 1H), 2.39 $2.31(\mathrm{~m}, 2 \mathrm{H}), 2.21-2.11(\mathrm{~m}, 2 \mathrm{H}), 2.07-1.97(\mathrm{~m}, 1 \mathrm{H})$, and $1.86(\mathrm{ddddd}, J=10.8$, $8.8,6.2,2.5,1.0 \mathrm{~Hz}, 1 \mathrm{H})$.

${ }^{13}$ C NMR (151 MHz, $\left.\mathbf{C D C l}_{3}\right): \delta 159.7,148.1,129.3,118.8,112.3,111.0,55.3,40.5$, 29.8, and 18.4.

HRMS (APCI): calc'd for $\mathrm{C}_{11} \mathrm{H}_{15} \mathrm{O}[\mathrm{M}+\mathrm{H}]^{+}$163.1117; found 163.1119.<smiles>c1ccc(C2CCCC2)cc1</smiles>

\section{Cyclopentylbenzene}

From $\mathrm{NiCl}_{2} \cdot$ glyme: Following the General Procedure B with 1,3-dioxoisoindolin-2-yl cyclopentancarboxylate $(0.25 \mathrm{mmol})$ and $\mathrm{PhZnCl} \cdot \mathrm{LiCl}(0.17 \mathrm{M}$ in $\mathrm{THF})$. Column chromatography with pentane afforded $30 \mathrm{mg}$ (81\%) of the title compound $\mathbf{1 4}$.

From $\mathrm{NiCl}_{2} \cdot 6 \mathrm{H}_{2} \mathrm{O}$ : Following the General Procedure B with 1,3-dioxoisoindolin-2-yl cyclopentancarboxylate $(0.25 \mathrm{mmol})$ and $\mathrm{PhZnCl} \cdot \mathrm{LiCl}(0.17 \mathrm{M}$ in THF). Column chromatography with pentane afforded $23 \mathrm{mg}$ (77\%) of the title compound 14.

Physical State: colorless oil.

$\boldsymbol{R}_{\boldsymbol{f}}=0.69$ (hexanes). 
${ }^{1}$ H NMR (600 MHz, CDCl $)$ ): $\delta 7.33-7.25(\mathrm{~m}, 4 \mathrm{H}), 7.22-7.18(\mathrm{~m}, 1 \mathrm{H}), 3.02$ (tt, $J$ $=9.8,7.5 \mathrm{~Hz}, 1 \mathrm{H}), 2.14-2.03(\mathrm{~m}, 2 \mathrm{H}), 1.89-1.79(\mathrm{~m}, 2 \mathrm{H}), 1.77-1.66(\mathrm{~m}, 2 \mathrm{H})$, and $1.66-1.58(\mathrm{~m}, 2 \mathrm{H})$.

${ }^{13}$ C NMR (151 MHz, $\mathbf{C D C l}_{3}$ ): $\delta$ 146.1, 127.8, 126.6, 125.2, 45.5, 34.2, and 25.1.

HRMS (APCI): calc'd for $\mathrm{C}_{11} \mathrm{H}_{13}[\mathrm{M}-\mathrm{H}]^{-}$145.1023; found 145.1005.

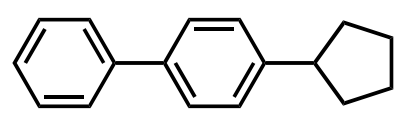

15

\section{4-Cyclopentyl-1,1'-biphenyl}

From $\mathrm{NiCl}_{2} \cdot$ glyme: Following the General Procedure B with 1,3-dioxoisoindolin-2-yl cyclopentancarboxylate $(0.25 \mathrm{mmol})$ and $4-\mathrm{Ph}-\mathrm{PhZnCl} \cdot \mathrm{LiCl}(0.22 \mathrm{M}$ in THF). Purification by PTLC (hexanes) afforded $22 \mathrm{mg}$ (66\%) of the title compound $\mathbf{1 5 .}$

Physical State: white solid; mp: $35^{\circ} \mathrm{C}$.

$\boldsymbol{R}_{\boldsymbol{f}}=0.30$ (hexanes).

${ }^{1}$ H NMR (600 MHz, $\left.\mathbf{C D C l}_{3}\right): \delta 7.60$ - 7.57 (m, 2H), $7.54-7.51(\mathrm{~m}, 2 \mathrm{H}), 7.45-7.40$ (m, 2H), $7.35-7.30(\mathrm{~m}, 3 \mathrm{H}), 3.09-2.99(\mathrm{~m}, 1 \mathrm{H}), 2.15-2.05(\mathrm{~m}, 2 \mathrm{H}), 1.90-1.79$ $(\mathrm{m}, 2 \mathrm{H}), 1.77-1.67(\mathrm{~m}, 2 \mathrm{H})$, and $1.67-1.57(\mathrm{~m}, 2 \mathrm{H})$.

${ }^{13}$ C NMR (150 MHz, $\left.\mathbf{C D C l}_{3}\right): \delta$ 145.8, 141.3, 138.8, 128.8, 127.7, 127.2, 127.1, 127.1, 45.8, 34.8, and 25.7.

HRMS (ESI-TOF): calc'd for $\mathrm{C}_{17} \mathrm{H}_{19}[\mathrm{M}+\mathrm{H}]^{+}$223.1481; found 223.1481.<smiles>Fc1ccc(C2CCCC2)cc1</smiles>

\section{1-Cyclopentyl-4-fluorobenzene}

From $\mathrm{NiCl}_{2} \cdot$ glyme: Following the General Procedure B with 1,3-dioxoisoindolin-2-yl cyclopentancarboxylate $(0.25 \mathrm{mmol})$ and $4-\mathrm{F}-\mathrm{PhZnCl} \cdot \mathrm{LiCl}(0.25 \mathrm{M}$ in THF). Column chromatography with pentane afforded $32 \mathrm{mg}$ (78\%) of the title compound 16.

Physical State: colorless oil.

$\boldsymbol{R}_{\boldsymbol{f}}=0.78$ (hexanes).

${ }^{1}$ H NMR (600 MHz, CDCl $)$ ): $\delta 7.26-7.16$ (m, 2H), $7.04-6.93$ (m, 2H), 2.99 (tt, $J$ $=9.9,7.4 \mathrm{~Hz}, 1 \mathrm{H}), 2.14-1.97(\mathrm{~m}, 2 \mathrm{H}), 1.91-1.78(\mathrm{~m}, 2 \mathrm{H}), 1.75-1.65(\mathrm{~m}, 2 \mathrm{H})$, and $1.62-1.50(\mathrm{~m}, 2 \mathrm{H})$. 
${ }^{13}$ C NMR (151 MHz, CDCl $): \delta 160.6(\mathrm{~d}, J=242.1 \mathrm{~Hz}, 1 \mathrm{C}), 141.6(\mathrm{~d}, J=7.5 \mathrm{~Hz}$, 1C), 127.9 (d, $J=7.5 \mathrm{~Hz}, 2 \mathrm{C}), 114.4$ (d, $J=20.9 \mathrm{~Hz}, 2 \mathrm{C}), 44.8,34.3$, and 25.0.

${ }^{19}$ F NMR (376 MHz, $\left.\mathbf{C D C l}_{3}\right): \delta-118.49$.

HRMS (APCI): calc'd for $\mathrm{C}_{11} \mathrm{H}_{12} \mathrm{~F}[\mathrm{M}-\mathrm{H}]^{-}$163.0929; found 163.0910.

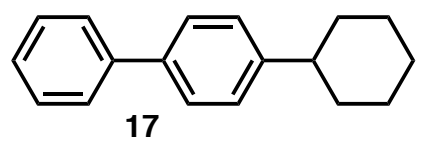

\section{4-Cyclohexyl-1,1'-biphenyl}

From $\mathrm{NiCl}_{2} \cdot$ glyme: Following the General Procedure B with 1,3-dioxoisoindolin-2-yl cyclohexancarboxylate $(0.25 \mathrm{mmol})$ and $4-\mathrm{Ph}-\mathrm{PhZnCl} \cdot \mathrm{LiCl}(0.22 \mathrm{M}$ in THF). PTLC (hexanes) afforded $27.7 \mathrm{mg}$ (78\%) of the title compound 17.

Physical State: white solid; mp: $55^{\circ} \mathrm{C}$.

$\boldsymbol{R}_{\boldsymbol{f}}=0.30$ (hexanes).

${ }^{1}$ H NMR (600 MHz, $\left.\mathbf{C D C l}_{3}\right): \delta 7.60-7.57$ (m, 2H), $7.54-7.50(\mathrm{~m}, 2 \mathrm{H}), 7.44-7.40$ $(\mathrm{m}, 2 \mathrm{H}), 7.34-7.30(\mathrm{~m}, 1 \mathrm{H}), 7.30-7.27(\mathrm{~m}, 2 \mathrm{H}), 2.59-2.51(\mathrm{~m}, 1 \mathrm{H}), 1.96-1.89$ $(\mathrm{m}, 2 \mathrm{H}), 1.90-1.83(\mathrm{~m}, 2 \mathrm{H}), 1.81-1.73(\mathrm{~m}, 1 \mathrm{H}), 1.51-1.36(\mathrm{~m}, 4 \mathrm{H})$, and $1.33-$ $1.22(\mathrm{~m}, 1 \mathrm{H})$.

${ }^{13}$ C NMR (150 MHz, $\left.\mathbf{C D C l}_{3}\right): \delta 147.4,141.3,138.9,128.8,127.4,127.1,127.2$, 127.1, 44.4, 34.6, 27.1, and 26.3.

HRMS (ESI-TOF): calc'd for $\mathrm{C}_{18} \mathrm{H}_{21}[\mathrm{M}+\mathrm{H}]^{+}$237.1638; found 237.1638.

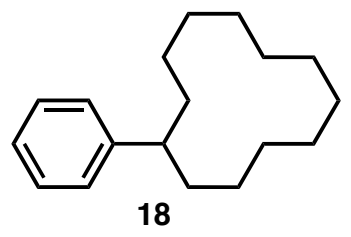

\section{Phenylcyclododecyl}

From $\mathrm{NiCl}_{2} \cdot$ glyme: Following the General Procedure B with 1,3-dioxoisoindolin-2-yl cyclododecylcarboxylate $(0.13 \mathrm{mmol})$ and $\mathrm{PhZnCl} \cdot \mathrm{LiCl}$ complex $(0.25 \mathrm{M}$ in $\mathrm{THF})$. Purification by PTLC (hexanes) afforded $16.1 \mathrm{mg}$ (50\%) of the title compound 18.

Physical State: white solid; mp: $45-47^{\circ} \mathrm{C}$.

$\boldsymbol{R}_{\boldsymbol{f}}=0.76$ (hexanes).

${ }^{1}$ H NMR (600 MHz, $\left.\mathbf{C D C l}_{3}\right): \delta 7.32(\mathrm{t}, J=7.6 \mathrm{~Hz}, 2 \mathrm{H}), 7.26-7.17$ (m, 3H), 2.80 (p, $J=6.5 \mathrm{~Hz}, 1 \mathrm{H}), 1.94-1.71(\mathrm{~m}, 2 \mathrm{H})$, and $1.64-1.00(\mathrm{~m}, 20 \mathrm{H})$. 
${ }^{13}$ C NMR (151 MHz, $\left.\mathbf{C D C l}_{3}\right): \delta$ 147.2, 127.7, 127.2, 125.2, 39.2, 31.1, 23.5, 23.5, 23.0, 22.8, and 22.3.

HRMS (APCI): calc'd for $\mathrm{C}_{18} \mathrm{H}_{27}[\mathrm{M}-\mathrm{H}]^{-}$243.2118; found 243.2104.

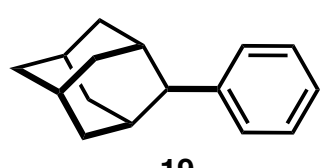

19

\section{2-Phenyladamantane}

From $\mathrm{NiCl}_{2} \cdot$ glyme: Following the General Procedure B with 1,3-dioxoisoindolin-2-yl adamantane 2-carboxylate $(0.20 \mathrm{mmol})$ and $\mathrm{PhZnCl} \cdot \mathrm{LiCl}(0.25 \mathrm{M}$ in THF). Column chromatography with pentane afforded $30 \mathrm{mg}$ (73\%) of the title compound 19.

Physical State: colorless oil.

$\boldsymbol{R}_{\boldsymbol{f}}=0.69$ (hexanes).

${ }^{1}$ H NMR (400 MHz, CDCl 3 ): $\delta 7.45-7.31(\mathrm{~m}, 4 \mathrm{H}), 7.22(\mathrm{t}, J=7.1 \mathrm{~Hz}, 1 \mathrm{H}), 3.06(\mathrm{~s}$, $1 \mathrm{H}), 2.52(\mathrm{~s}, 2 \mathrm{H}), 2.09-1.74(\mathrm{~m}, 10 \mathrm{H})$, and $1.60(\mathrm{~d}, J=12.5 \mathrm{~Hz}, 2 \mathrm{H})$.

${ }^{13}$ C NMR (101 MHz, $\left.\mathbf{C D C l}_{3}\right): \delta 144.4,128.1,126.9,125.2,46.8,39.2,37.9,32.0$, $31.1,28.1$, and 27.8 .

HRMS (APCI): calc'd for $\mathrm{C}_{16} \mathrm{H}_{19}[\mathrm{M}-\mathrm{H}]^{-}$211.1492; found 211.1494.

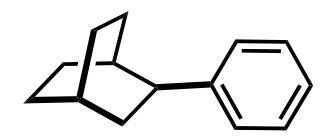

20

\section{2-Phenyl bicycle[2.2.2]octane}

From $\mathrm{NiCl}_{2} \cdot$ glyme: Following the General Procedure B with 1,3-dioxoisoindolin-2-yl bicyclo[2.2.2] octane 2-carboxylate $(0.20 \mathrm{mmol})$ and $\mathrm{PhZnCl} \cdot \mathrm{LiCl}(0.25 \mathrm{M}$ in THF). Column chromatography with pentane afforded $25 \mathrm{mg}(67 \%)$ of the title compound 20.

Physical State: colorless oil.

$\boldsymbol{R}_{\boldsymbol{f}}=0.70$ (hexanes).

${ }^{1}$ H NMR (400 MHz, CDCl $\left.)_{3}\right): \delta 7.37-7.30(\mathrm{~m}, 4 \mathrm{H}), 7.26-7.17(\mathrm{~m}, 1 \mathrm{H}), 3.02$ (ddd, $J=10.9,7.4,1.7 \mathrm{~Hz}, 1 \mathrm{H}), 2.09-1.94(\mathrm{~m}, 1 \mathrm{H}), 1.90-1.48(\mathrm{~m}, 10 \mathrm{H})$, and $1.41-1.26$ (m, 1H).

${ }^{13}$ C NMR (101 MHz, $\left.\mathbf{C D C l}_{3}\right): \delta$ 146.6, 128.1, 127.7, 125.5, 41.9, 32.3, 31.0, 27.6, 26.0, 25.4, 24.8, and 20.5. 
HRMS (APCI): calc'd for $\mathrm{C}_{14} \mathrm{H}_{17}[\mathrm{M}-\mathrm{H}]^{-}$185.1330; found 185.1325.

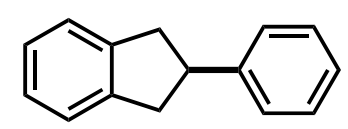

21

\section{2-Phenyl-2,3-dihydro-1H-indene}

From $\mathrm{NiCl}_{2} \cdot$ glyme: Following the General Procedure B with 1,3-dioxoisoindolin-2-yl 2,3-dihydro-1H-indene-2-carboxylate $(0.20 \mathrm{mmol})$ and $\mathrm{PhZnCl} \cdot \mathrm{LiCl}(0.22 \mathrm{M}$ in THF). Column chromatography with pentane afforded $20 \mathrm{mg}(52 \%)$ of the title compound 21.

Physical State: colorless oil.

$\boldsymbol{R}_{\boldsymbol{f}}=0.38$ (hexanes).

${ }^{1}$ H NMR (400 MHz, CDCl $)$ ): $\delta 7.46-6.92(\mathrm{~m}, 9 \mathrm{H}), 3.74(\mathrm{p}, J=8.6 \mathrm{~Hz}, 1 \mathrm{H}), 3.40$ (dd, $J=15.6,8.2 \mathrm{~Hz}, 2 \mathrm{H})$, and $3.14(\mathrm{dd}, J=15.6,9.0 \mathrm{~Hz}, 2 \mathrm{H})$.

${ }^{13}$ C NMR (101 MHz, $\left.\mathbf{C D C l}_{3}\right): \delta$ 145.5, 143.0, 128.5, 127.1, 126.5, 126.2, 124.3, 45.5, and 40.9.

HRMS (APCI): calc'd for $\mathrm{C}_{15} \mathrm{H}_{13}[\mathrm{M}-\mathrm{H}]^{+}$193.1017; found 193.1012.<smiles>COc1ccc(C(C)C)cc1</smiles>

\section{1-isopropyl-4-methoxybenzene}

From $\mathrm{NiCl}_{2} \cdot$ glyme: Following the General Procedure B with 1,3-dioxoisoindolin-2-yl isobutyrate $(0.25 \mathrm{mmol})$ and $4-\mathrm{OMePhZnCl} \cdot \mathrm{LiCl}(0.20 \mathrm{M}$ in THF). Purification by PTLC (99:1 hexanes:Et $2 \mathrm{O}$ ) afforded 22 (19 mg, 51\% yield).

Physical State: clear oil.

$\boldsymbol{R} \boldsymbol{f}=0.31\left(9: 1\right.$ hexanes $\left./ \mathrm{CH}_{2} \mathrm{Cl}_{2}\right)$.

1H NMR (600 MHz, CDCl $)$ ): $\delta 7.19-7.13(\mathrm{~m}, 2 \mathrm{H}), 6.86-6.83(\mathrm{~m}, 2 \mathrm{H}), 3.79(\mathrm{~s}$, $3 \mathrm{H}), 2.87$ (hept, $\mathrm{J}=6.9 \mathrm{~Hz}, 1 \mathrm{H})$, and $1.23(\mathrm{~d}, \mathrm{~J}=6.9 \mathrm{~Hz}, 6 \mathrm{H})$.

13C NMR (151 MHz, $\mathbf{C D C l}_{3}$ ): $\delta$ 157.8, 141.2, 127.4, 113.8, 55.4, 33.4, and 24.4.

HRMS (ESI-TOF): calc'd for $\mathrm{C}_{10} \mathrm{H}_{15} \mathrm{O}[\mathrm{M}+\mathrm{H}]^{+} 151.1117$; found 151.1118 


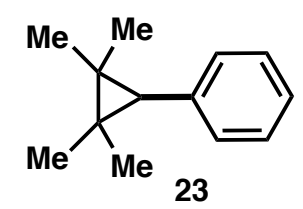

\section{(2,2,3,3-Tetramethylcyclopropyl)benzene}

From NiCl 2 glyme: Following the General Procedure B with 4,5,6,7-tetrachloro-1,3dioxoisoindolin-2-yl 2,2,3,3-tetramethylcyclopropane-1-carboxylate $(0.25 \mathrm{mmol})$ and $\mathrm{PhZnCl} \cdot \mathrm{LiCl}(0.25 \mathrm{M}$ in THF). Column chromatography with pentane afforded $15 \mathrm{mg}$ (35\%) of the title compound 23 .

From $\mathrm{NiCl}_{2} \cdot 6 \mathrm{H}_{2} \mathrm{O}$ : Following the General Procedure B with 4,5,6,7-tetrachloro-1,3dioxoisoindolin-2-yl 2,2,3,3-tetramethylcyclopropane-1-carboxylate $(0.25 \mathrm{mmol})$ and $\mathrm{PhZnCl} \cdot \mathrm{LiCl}(0.25 \mathrm{M}$ in THF). Column chromatography with pentane afforded $12 \mathrm{mg}$ (31\%) of the title compound 23.

Physical State: colorless oil.

$\boldsymbol{R}_{\boldsymbol{f}}=0.76$ (hexanes).

${ }^{1}$ H NMR (400 MHz, $\left.\mathbf{C D C l}_{3}\right): \delta 7.37-7.29(\mathrm{~m}, 3 \mathrm{H}), 7.27-7.12(\mathrm{~m}, 2 \mathrm{H}), 1.62(\mathrm{~s}$, $1 \mathrm{H}), 1.33(\mathrm{~s}, 6 \mathrm{H})$, and $1.01(\mathrm{~s}, 6 \mathrm{H})$.

${ }^{13}$ C NMR (101 MHz, $\mathbf{C D C l}_{3}$ ): $\delta$ 139.4, 131.0, 127.9, 125.5, 37.8, 23.9, 23.2, and 19.1.

HRMS (APCI): calc'd for $\mathrm{C}_{13} \mathrm{H}_{17}[\mathrm{M}-\mathrm{H}]^{+}$174.1408; found 174.1402.

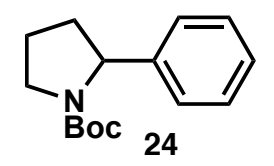

\section{tert-Butyl 2-phenylpyrrolidine-1-carboxylate}

From $\mathrm{NiCl}_{2} \cdot$ glyme: A screw-cap culture tube with Teflon ${ }^{\mathrm{TM}}$ septum and stir bar was charged with 1-(tert-butoxycarbonyl)pyrrolidine-2-carboxylic acid (54 mg, 0.25 mmol) and HATU (95 mg, $0.25 \mathrm{mmol}$ ) in DMF (anhydrous, $1.0 \mathrm{~mL}$ ) followed by the addition of $\mathrm{Et}_{3} \mathrm{~N}$ ( $35 \mu \mathrm{L}, 0.25 \mathrm{mmol}$ ). The mixture was stir at $\mathrm{rt}$ for $30 \mathrm{~min}^{6}{ }^{6} \mathrm{~A}$ solution of $\mathrm{NiCl}_{2} \cdot$ glyme $(20 \mathrm{~mol} \%)$ and di- $t$ Bubipy $(40 \mathrm{~mol} \%)$ in $1.0 \mathrm{~mL}$ of DMF was added to the reaction mixture and stirred at $\mathrm{rt}$ for $5 \mathrm{~min}$. $\mathrm{PhZnCl} \cdot \mathrm{LiCl}(0.25 \mathrm{M}$ in THF) was added dropwise to the reaction mixture, which was stirred for $12 \mathrm{~h}$. Normal work up and purification by column chromatography (20:3 hexanes:EtOAc) to provide $35 \mathrm{mg}$ (56\%) of the title compound 24 . 
From $\mathrm{NiCl}_{2} \cdot 6 \mathrm{H}_{2} \mathrm{O}$ : A screw-cap culture tube with Teflon ${ }^{\mathrm{TM}}$ septum and stir bar was charged with 1-(tert-butoxycarbonyl)pyrrolidine-2-carboxylic acid (54 mg, 0.25 mmol) and HATU (95 mg, $0.25 \mathrm{mmol}$ ) in DMF (anhydrous, $1.0 \mathrm{~mL}$ ) followed by the addition of $\mathrm{Et}_{3} \mathrm{~N}(35 \mu \mathrm{L}, 0.25 \mathrm{mmol})$. The mixture was stirred at $\mathrm{rt}$ for $30 \mathrm{~min}^{6} \mathrm{~A}$ solution of $\mathrm{NiCl}_{2} \cdot$ glyme $(20 \mathrm{~mol} \%)$ and di- $t$ Bubipy $(40 \mathrm{~mol} \%)$ in $1.0 \mathrm{~mL}$ of DMF was added to the reaction mixture and stir at $\mathrm{rt}$ for $5 \mathrm{~min}$. $\mathrm{PhZnCl} \cdot \mathrm{LiCl}(0.25 \mathrm{M}$ in THF) was added dropwise to the reaction mixture, which was stirred for $12 \mathrm{~h}$. Normal work up and purification by column chromatography (20:3 hexanes:EtOAc) to provide $36 \mathrm{mg}$ (58\%) of the title compound 24.

Physical State: colorless oil.

$\mathbf{R}_{\boldsymbol{f}}=0.53$ (20:3 hexanes:EtOAc).

The product gives two sets of NMR signals, owing to the presence of rotamers.

${ }^{1} \mathbf{H}$ NMR $\left(600 \mathrm{MHz}, \mathrm{CDCl}_{3}\right): \delta$ 7.27-7.23 (m, 2H), 7.19-7.13 (m, 3H), 4.93 (brs, $0.3 \mathrm{H}), 4.73$ (brs, 0.7H), 3.60-3.49 (m, 2H), 2.30 (br, $1 \mathrm{H}), 1.89$ (br, $1 \mathrm{H}), 1.85-1.75$ (m, $2 \mathrm{H}), 1.43(\mathrm{~s}, 3 \mathrm{H})$, and $1.15(\mathrm{~s}, 6 \mathrm{H})$.

${ }^{13}$ C NMR (151 MHz, $\left.\mathrm{CDCl}_{3}\right): \delta 154.7,145.3,144.2,128.4,128.2,126.6,125.6$, $125.5,79.3,61.5,60.8,47.5,47.2,36.2,35.0,28.7,28.3,23.6$, and 23.3.

HRMS (ESI-TOF): calc'd for $\mathrm{C}_{15} \mathrm{H}_{22} \mathrm{NO}_{2}{ }^{+}[\mathrm{M}+\mathrm{H}]^{+}$248.1645; found 248.1645.

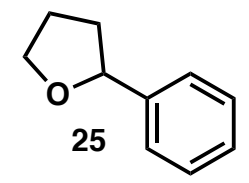

\section{2-Phenyltetrahydrofuran}

From $\mathrm{NiCl}_{2} \cdot$ glyme: Following the General Procedure B with 1,3-dioxoisoindolin-2-yl tetrahydrofuran-2-carboxylate $(0.25 \mathrm{mmol})$ and $\mathrm{PhZnCl} \cdot \mathrm{LiCl}(0.21 \mathrm{M}$ in $\mathrm{THF})$. Purification by column chromatography (10:1 hexanes:EtOAc) to afford $20 \mathrm{mg}(55 \%)$ of the title compound $\mathbf{2 5}$.

From $\mathrm{NiCl}_{2} \cdot 6 \mathrm{H}_{2} \mathrm{O}$ : Following the General Procedure B with 1,3-dioxoisoindolin-2-yl tetrahydro-2H-pyran-4-carboxylate $(0.25 \mathrm{mmol})$ and $\mathrm{PhZnCl} \cdot \mathrm{LiCl}(0.18 \mathrm{M}$ in THF $)$. Purification by column chromatography (10:1 hexanes:EtOAc) to afford $9 \mathrm{mg}(25 \%)$ of the title compound $\mathbf{2 5}$.

Physical State: colorless oil.

$\boldsymbol{R}_{\boldsymbol{f}}=0.53$ (10:1 hexanes:EtOAc). 
${ }^{1}$ H NMR (600 MHz, CDCl$\left.)_{3}\right): \delta 7.35-7.32(\mathrm{~m}, 4 \mathrm{H}), 7.26-7.24(\mathrm{~m}, 1 \mathrm{H}), 4.90(\mathrm{t}, J=$ 7.2, Hz, 1H), 4.20-4.05 (m, 1H), 3.94 (td, $J=7.9,6.4 \mathrm{~Hz}, 1 \mathrm{H}), 2.33$ (ddd, $J=12.4$, 7.2, $5.5 \mathrm{~Hz}, 1 \mathrm{H}), 2.07-1.94(\mathrm{~m}, 2 \mathrm{H})$, and $1.81(\mathrm{dq}, J=12.3,7.7 \mathrm{~Hz}, 1 \mathrm{H})$.

${ }^{13}$ C NMR (151 MHz, $\left.\mathbf{C D C l}_{3}\right): \delta$ 143.6, 128.4, 127.2, 125.8, 80.8, 68.8, 34.8, and 26.2 .

HRMS (ESI-TOF): calc'd for $\mathrm{C}_{10} \mathrm{H}_{13} \mathrm{O}[\mathrm{M}+\mathrm{H}]^{+}$149.0961; found 149.0959.

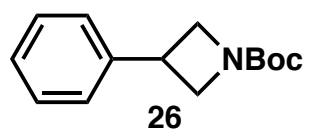

tert-Butyl 3-phenylazetidine-1-carboxylate

From $\mathrm{NiCl}_{2} \cdot$ glyme: Following the General Procedure B with 1-(tert-butyl) 3-(4,5,6,7tetrachloro-1,3-dioxoisoindolin-2-yl) azetidine-1,3-dicarboxylate (0.25 mmol), 2,2'bipyridine (40 mol\%, in place of di- $t$ Bubipy), and $\mathrm{PhZnCl} \cdot \mathrm{LiCl}(0.28 \mathrm{M}$ in THF). Purification by column chromatography (4:1 hexanes:EtOAc) afforded $33 \mathrm{mg}$ (56\%) of the title compound 26.

From $\mathrm{NiCl}_{2} \cdot 6 \mathrm{H}_{2} \mathrm{O}$ : Following the General Procedure B with 1-(tert-butyl) 3-(4,5,6,7tetrachloro-1,3-dioxoisoindolin-2-yl) azetidine-1,3-dicarboxylate (0.25 mmol), 2,2'bipyridine (40 mol\%, in place of di- $t$ Bubipy), and $\mathrm{PhZnCl} \cdot \mathrm{LiCl}(0.25 \mathrm{M}$ in THF). Purification by column chromatography (4:1 hexanes:EtOAc) afforded $27 \mathrm{mg}(46 \%)$ of the title compound 26.

Physical State: colorless oil.

$\boldsymbol{R}_{\boldsymbol{f}}=0.63$ (4:1 hexanes:EtOAc).

${ }^{1}$ H NMR (600 MHz, $\left.\mathbf{C D C l}_{3}\right): \delta 7.37$ - 7.33 (m, 2H), $7.32-7.30$ (m, 2H), $7.28-7.24$ $(\mathrm{m}, 1 \mathrm{H}), 4.33(\mathrm{dd}, J=8.6,8.6 \mathrm{~Hz}, 2 \mathrm{H}), 3.98(\mathrm{dd}, J=8.6,6.1 \mathrm{~Hz}, 2 \mathrm{H}), 3.73(\mathrm{tt}, J=$ 8.7, $6.0 \mathrm{~Hz}, 1 \mathrm{H})$, and $1.47(\mathrm{~s}, 9 \mathrm{H})$.

${ }^{13} \mathbf{C}$ NMR (151 MHz, $\left.\mathbf{C D C l}_{3}\right): \delta 156.6,142.4,128.9,127.1,126.9,79.7,56.6,33.7$, and 28.6.

HRMS (ESI-TOF): calc'd for $\mathrm{C}_{14} \mathrm{H}_{20} \mathrm{NO}_{2}[\mathrm{M}+\mathrm{H}]^{+}$234.1488; found 234.1489.

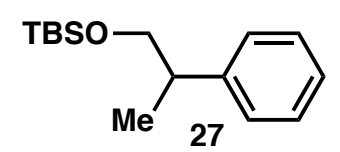

tert-butyldimethyl(2-phenylpropoxy)silane 
From $\mathrm{NiCl}_{2} \cdot$ glyme: Following the General Procedure B with 1,3-dioxoisoindolin-2-yl 3-((tert-butyldimethylsilyl)oxy)-2-methylpropanoate $(0.25 \mathrm{mmol})$ and $\mathrm{PhZnCl} \cdot \mathrm{LiCl}$ (0.21 M in THF). Purification by PTLC (hexanes) afforded $32 \mathrm{mg}(51 \%)$ of the title compound 27.

From $\mathrm{NiCl}_{2} \cdot 6 \mathrm{H}_{2} \mathrm{O}$ : Following the General Procedure B with 1,3-dioxoisoindolin-2-yl tetrahydro-2H-pyran-4-carboxylate $(0.25 \mathrm{mmol})$ and $\mathrm{PhZnCl} \cdot \mathrm{LiCl}(0.29 \mathrm{M}$ in $\mathrm{THF})$. Purification by column chromatography (gradient elution, hexanes to 9:1 hexanes:EtOAc) afforded $40 \mathrm{mg}(64 \%)$ of the title compound 27.

Physical State: clear oil.

$\boldsymbol{R}_{\boldsymbol{f}}=0.33$ (9:1 hexanes:EtOAc).

${ }^{1}$ H NMR (600 MHz, $\left.\mathbf{C D C l}_{3}\right): \delta 7.31-7.27(\mathrm{~m}, 2 \mathrm{H}), 7.24-7.18(\mathrm{~m}, 3 \mathrm{H}), 3.69$ (dd, $J$ $=9.8,5.9 \mathrm{~Hz}, 1 \mathrm{H}), 3.59(\mathrm{dd}, J=9.8,7.6 \mathrm{~Hz}, 1 \mathrm{H}), 2.94-2.84(\mathrm{~m}, 1 \mathrm{H}), 1.29(\mathrm{~d}, J=$ $7.0 \mathrm{~Hz}, 3 \mathrm{H}), 0.86(\mathrm{~s}, 9 \mathrm{H}),-0.03(\mathrm{~s}, 3 \mathrm{H})$, and $-0.04(\mathrm{~s}, 3 \mathrm{H})$.

${ }^{13}$ C NMR (151 MHz, $\left.\mathbf{C D C l}_{3}\right): \delta$ 144.7, 128.3, 127.7, 126.4, 69.4, 42.6, 26.1, 18.5, 17.6, and $-5.3(2 \mathrm{C})$.

HRMS (ESI-TOF): calc'd for $\mathrm{C}_{15} \mathrm{H}_{27} \mathrm{OSi}[\mathrm{M}+\mathrm{H}]^{+}$251.1826; found 251.1828.

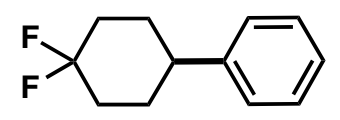

28

\section{(4,4-Difluorocyclohexyl)benzene}

From $\mathrm{NiCl}_{2} \cdot$ glyme: Following the General Procedure B with 1,3-dioxoisoindolin-2-yl 4,4-difluorocyclohexane-1-carboxylate $(0.25 \mathrm{mmol})$ and $\mathrm{PhZnCl} \cdot \mathrm{LiCl}(0.25 \mathrm{M}$ in THF). Purification by column chromatography (pentane) afforded $36 \mathrm{mg}(73 \%)$ of the title compound 28.

From $\mathrm{NiCl}_{2} \cdot 6 \mathrm{H}_{2} \mathrm{O}$ : Following the General Procedure B with 1,3-dioxoisoindolin-2-yl 4,4-difluorocyclohexane-1-carboxylate $(0.25 \mathrm{mmol})$ and $\mathrm{PhZnCl} \cdot \mathrm{LiCl}(0.25 \mathrm{M}$ in THF). Column chromatography (pentane) afforded $15 \mathrm{mg}(31 \%)$ of the title compound 28.

Physical State: white solid; mp: $40-42{ }^{\circ} \mathrm{C}$.

$\boldsymbol{R}_{\boldsymbol{f}}=0.51$ (Hexanes:EtOAc 9:1);

${ }^{1}$ H NMR (400 MHz, $\mathbf{C D C l}_{3}$ ): $\delta 7.36$ - 7.32 (m, 2H), 7.28 - 7.24 (m, 3H), $2.66-2.61$ $(\mathrm{m}, 1 \mathrm{H}), 2.27-2.21(\mathrm{~m}, 2 \mathrm{H}), 2.02-1.71(\mathrm{~m}, 6 \mathrm{H})$. 
${ }^{13}$ C NMR (151 MHz, $\left.\mathbf{C D C l}_{3}\right): \delta 144.7$ (d, $\left.J=2.0 \mathrm{~Hz}\right), 128.1,126.3,126.0,122.7$ $(\mathrm{dd}, J=242.5,239.2 \mathrm{~Hz}, 1 \mathrm{C}), 42.1,33.6(\mathrm{dd}, J=25.6,22.4 \mathrm{~Hz}, 2 \mathrm{C})$, and 29.8 (d, $J=$ $9.9 \mathrm{~Hz}, 2 \mathrm{C})$.

${ }^{19}$ F NMR (376 MHz, $\left.\mathbf{C D C l}_{3}\right): \delta-91.86(\mathrm{~d}, J=235.8 \mathrm{~Hz})$, and $-102.61(\mathrm{~d}, J=235.8$ $\mathrm{Hz})$.

GC/MS (m/z): $196\left(\mathrm{M}^{+}\right), 117,104,91$.

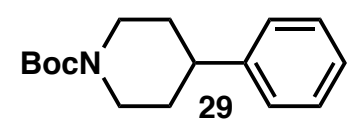

tert-Butyl 4-phenylpiperidine-1-carboxylate

Following the General Procedure B with 1-(tert-butyl) 4-(4,5,6,7-tetrachloro-1,3dioxoisoindolin-2-yl) piperidine-1,4-dicarboxylate $(0.1 \mathrm{mmol})$ and $\mathrm{PhZnCl} \cdot \mathrm{LiCl}(0.20$ $\mathrm{M}$ in THF). Purification by column chromatography (30:1 hexanes:EtOAc) afforded $14 \mathrm{mg}$ (54\%) of the title compound 29.

Physical State: colorless oil.

$\boldsymbol{R}_{\boldsymbol{f}}=0.55$ (6:1 hexanes:EtOAc).

${ }^{1}$ H NMR (400 MHz, $\left.\mathbf{C D C l}_{3}\right): \delta 7.32-7.30$ (m, 2H), $7.22-7.20$ (m, 3H), 4.24 (d, $J$ $=13.3 \mathrm{~Hz}, 2 \mathrm{H}), 2.85-2.76(\mathrm{~m}, 2 \mathrm{H}), 2.64(\mathrm{tt}, J=12.2,3.6 \mathrm{~Hz}, 1 \mathrm{H}), 1.89-1.78(\mathrm{~m}$, $2 \mathrm{H}), 1.67-1.58(\mathrm{~m}, 2 \mathrm{H})$, and $1.48(\mathrm{~s}, 9 \mathrm{H})$.

${ }^{13}$ C NMR (101 MHz, $\left.\mathbf{C D C l}_{3}\right): \delta 155.0,146.0,128.7,126.9,126.5,79.6,44.6,42.9$, 33.3 , and 28.7 .

Spectroscopic data matches that reported in the literature. ${ }^{7}$

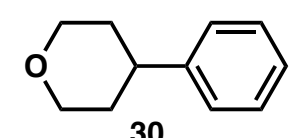

\section{4-phenyltetrahydro-2H-pyran}

From $\mathrm{NiCl}_{2} \cdot$ glyme: Following the General Procedure B with 1,3-dioxoisoindolin-2-yl tetrahydro-2H-pyran-4-carboxylate $(0.25 \mathrm{mmol})$ and $\mathrm{PhZnCl} \cdot \mathrm{LiCl}(0.21 \mathrm{M}$ in THF). Purification by column chromatography (10:1 hexanes:EtOAc) afforded $26 \mathrm{mg}(65 \%)$ of the title compound $\mathbf{3 0 .}$

From $\mathrm{NiCl}_{2} \cdot 6 \mathrm{H}_{2} \mathrm{O}$ : Following the General Procedure B with 1,3-dioxoisoindolin-2-yl tetrahydro-2H-pyran-4-carboxylate $(0.25 \mathrm{mmol})$ and $\mathrm{PhZnCl} \cdot \mathrm{LiCl}(0.18 \mathrm{M}$ in THF). Purification by column chromatography with (10:1 hexanes:EtOAc) afforded $12 \mathrm{mg}$ (30\%) of the title compound $\mathbf{3 0 .}$ 
Physical State: white solid; $\mathrm{mp}: 49-50{ }^{\circ} \mathrm{C}$.

$\boldsymbol{R}_{\boldsymbol{f}}=0.53$ (10:1 hexanes:EtOAc).

${ }^{1}$ H NMR (600 MHz, $\left.\mathbf{C D C l}_{3}\right): \delta 7.34-7.31(\mathrm{~m}, 2 \mathrm{H}), 7.24-7.21(\mathrm{~m}, 3 \mathrm{H}), 4.09$ (dd, $J$ $=11.3,4.0 \mathrm{~Hz}, 2 \mathrm{H}), 3.54(\mathrm{td}, J=11.7,2.0 \mathrm{~Hz}, 2 \mathrm{H}), 2.79-2.73(\mathrm{~m}, 1 \mathrm{H})$, and $1.91-$ $1.71(\mathrm{~m}, 4 \mathrm{H})$;

${ }^{13}$ C NMR (151 MHz, $\left.\mathbf{C D C l}_{3}\right): \delta 146.0,128.7,126.9,126.5,68.6,41.7$, and 34.1.

HRMS (ESI-TOF): calc'd for $\mathrm{C}_{11} \mathrm{H}_{15} \mathrm{O}^{+}[\mathrm{M}+\mathrm{H}]^{+} 163.1117$; found 163.1116 .

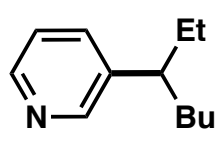

31

\section{Preparation of 3-pyridylzinc chloride lithium chloride reagent.}

A dry and argon-charged 10-mL flask was charged with $i \operatorname{PrMgCl} \cdot \mathrm{LiCl}(1.06 \mathrm{~mL}, 1.04$ $\mathrm{M}$ in THF, $1.10 \mathrm{mmol})$ and diluted with THF $(1 \mathrm{~mL})$. The reaction mixture was cooled to $0{ }^{\circ} \mathrm{C}$ and 3-bromopyridine $(96 \mathrm{uL}, 1.0 \mathrm{mmol}$ ) was added in one portion. The resulting solution was kept stirring at room temperature for $30 \mathrm{~min}$ before $\mathrm{ZnCl}_{2}$ (1.2 $\mathrm{mL}, 1.0 \mathrm{M}$ in THF, $1.2 \mathrm{mmol}$ ) was added in. After $30 \mathrm{~min}$ stirring, the 3-PyZnCl$\cdot \mathrm{LiCl}$ solution was titrated as $0.21 \mathrm{M}$ in THF.

From phthalimide ester: Following the General Procedure with 1-(tert-butyl) 4-(1,3dioxoisoindolin-2-yl) piperidine-1,4-dicarboxylate $(0.1 \mathrm{mmol})$ and $33-\mathrm{PyZnCl} \cdot \mathrm{LiCl}$ (0.21 $\mathrm{M}$ in THF). Column chromatography (10:1 hexanes:EtOAc) afforded $6 \mathrm{mg}$ (34\%) of the title compound 31.

From HATU ester: Following the General Procedure with 2-ethylhexanoic acid (0.1 $\mathrm{mmol}), \mathrm{HATU}$, and 3-PyZnCl$\cdot \mathrm{LiCl}(0.21 \mathrm{M}$ in THF). Column chromatography (10:1 hexanes:EtOAc) afforded $9.6 \mathrm{mg}$ (54\%) of the title compound 31.

Physical State: colorless oil.

$\boldsymbol{R}_{\boldsymbol{f}}=0.50$ (5:1 hexanes:EtOAc).

${ }^{1}$ H NMR (400 MHz, CDCl 3 ): $\delta 8.43(\mathrm{dd}, J=4.7,1.7 \mathrm{~Hz}, 1 \mathrm{H}), 8.41-8.37(\mathrm{~m}, 1 \mathrm{H})$, $7.45(\mathrm{dt}, J=7.8,2.0 \mathrm{~Hz}, 1 \mathrm{H}), 7.22(\mathrm{ddd}, J=7.9,4.8,0.9 \mathrm{~Hz}, 1 \mathrm{H}), 2.41$ (td, $J=9.3$, $4.8 \mathrm{~Hz}, 1 \mathrm{H}), 1.69$ (dddt, $J=21.6,13.5,10.7,5.5 \mathrm{~Hz}, 2 \mathrm{H}), 1.59-1.49$ (m, 2H), 1.32 $1.19(\mathrm{~m}, 2 \mathrm{H}), 1.19-1.11(\mathrm{~m}, 1 \mathrm{H}), 1.10-1.03(\mathrm{~m}, 1 \mathrm{H}), 0.82(\mathrm{t}, J=7.3 \mathrm{~Hz}, 3 \mathrm{H})$, and $0.76(\mathrm{t}, J=7.4 \mathrm{~Hz}, 3 \mathrm{H})$. 
${ }^{13}$ C NMR (151 MHz, $\left.\mathbf{C D C l}_{3}\right): \delta$ 150.0, 147.5, 141.3, 134.9, 123.5, 45.4, 36.0, 29.8, 29.6, 22.8, 14.1, and 12.2.

HRMS (ESI-TOF): calc'd for $\mathrm{C}_{12} \mathrm{H}_{20} \mathrm{~N}[\mathrm{M}+\mathrm{H}]^{+}$178.1590; found 178.1590.<smiles>CCC(CC)c1cccc(OC)n1</smiles>

\section{2-(heptan-3-yl)-6-methoxypyridine}

Following the General Procedure with 4,5,6,7-tetrachloro-1,3-dioxoisoindolin-2-yl 2ethylhexanoate $(0.1 \mathrm{mmol})$ and 6-methoxy-2-PyZnCl$\cdot \mathrm{LiCl}(0.05 \mathrm{M}$ in THF). Purification by column chromatography (10:1 hexanes: $\left.\mathrm{CH}_{2} \mathrm{Cl}_{2}\right)$ afforded $9 \mathrm{mg}(42 \%)$ of the title compound $\mathbf{3 2}$.

Physical State: colorless oil.

$\boldsymbol{R}_{\boldsymbol{f}}=0.4\left(10: 1\right.$ hexanes: $\left.\mathrm{CH}_{2} \mathrm{Cl}_{2}\right)$.

${ }^{1}$ H NMR (400 MHz, CDCl 3$): \delta 7.44(\mathrm{dd}, J=8.2,7.2 \mathrm{~Hz}, 1 \mathrm{H}), 6.64(\mathrm{dd}, J=7.2,0.8$ $\mathrm{Hz}, 1 \mathrm{H}), 6.51(\mathrm{dd}, J=8.2,0.9 \mathrm{~Hz}, 1 \mathrm{H}), 3.90$ (s, 3H), 2.48 (tt, $J=9.1,5.2 \mathrm{~Hz}, 1 \mathrm{H})$, $1.75-1.68(\mathrm{~m}, 2 \mathrm{H}), 1.66-1.56(\mathrm{~m}, 2 \mathrm{H}), 1.32-1.22(\mathrm{~m}, 2 \mathrm{H}), 1.20-1.13(\mathrm{~m}, 1 \mathrm{H})$, $1.11-1.03(\mathrm{~m}, 1 \mathrm{H}), 0.83(\mathrm{t}, J=7.3 \mathrm{~Hz}, 3 \mathrm{H})$, and $0.76(\mathrm{t}, J=7.4 \mathrm{~Hz}, 3 \mathrm{H})$.

${ }^{13}$ C NMR (101 MHz, $\left.\mathbf{C D C l}_{3}\right): \delta 163.8,163.3,138.4,115.7,107.2,53.2,49.3,34.9$, $30.00,28.4,23.0,14.2$, and 12.3 .

HRMS (ESI-TOF): calc'd for $\mathrm{C}_{13} \mathrm{H}_{22} \mathrm{NO}[\mathrm{M}+\mathrm{H}]^{+}$208.1696; found 208.1695.

\section{Mechanistic investigations}

Stoichiometric reaction of activated tetrahydrofuranoic ester and Ni complex 2.

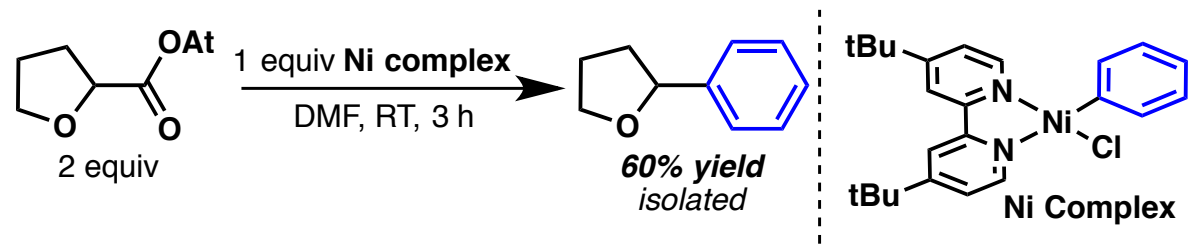

From racemic acid. A $25 \mathrm{~mL}$ Teflon ${ }^{\mathrm{TM}}$ screw-capped test tube was charged with 2tetrahydrofuroic acid $(46 \mu \mathrm{L}, 0.50 \mathrm{mmol}), \mathrm{HATU}(190 \mathrm{mg}, 0.50 \mathrm{mmol})$ and $\mathrm{Et}_{3} \mathrm{~N}(70$ $\mu \mathrm{L}, 0.50 \mathrm{mmol})$. The tube was sealed and evacuated and back-filled with Ar. Anhydrous DMF ( $1 \mathrm{~mL})$ was added and stirred for 15 minutes. In another $25 \mathrm{~mL}$ Teflon $^{\text {TM }}$ screw capped, $2^{2}$ (174 mg, $\left.0.25 \mathrm{mmol}\right)$ and di- $t$ Bubipy (67 mg, $0.25 \mathrm{mmol}$ ) 
were dissolved in DMF under Ar. The solution with the activated ester was then added via syringe to the Nickel complex solution at room temperature. The mixture slowly turned from red-yellow to clear green. After 3 hours, the reaction was quenched with $\mathrm{HCl} 1 \mathrm{~N}(2 \mathrm{~mL})$, and $\mathrm{Et}_{2} \mathrm{O}$ was added. The organic layer was dried over $\mathrm{NaSO}_{4}$ (anh), filtered and concentrated. Column chromatography (hexanes:EtOAc 9:1) affored $22 \mathrm{mg}$ (60\% yield) of compound 25 as a yellowish oil.

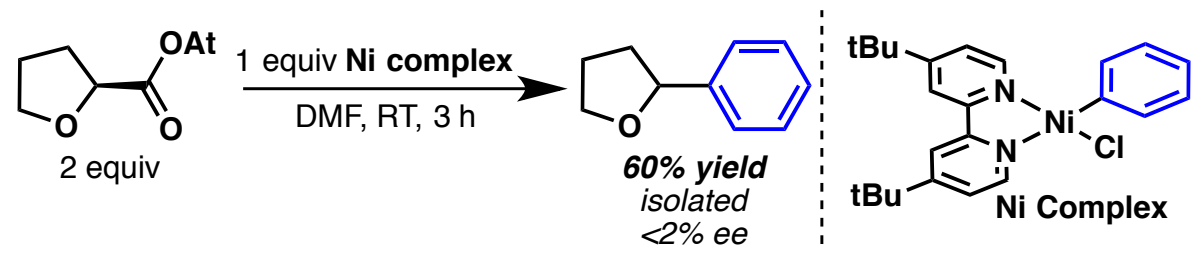

From enantiopure acid: A $25 \mathrm{~mL}$ screw-cap culture tube with Teflon ${ }^{\mathrm{TM}}$ septum was charged with (S)-2-tetrahydrofuroic acid (99\% ee, $46 \mu \mathrm{L}, 0.50 \mathrm{mmol})$, HATU (190 $\mathrm{mg}, 0.50 \mathrm{mmol})$ and $\mathrm{Et}_{3} \mathrm{~N}(70 \mu \mathrm{L}, 0.50 \mathrm{mmol})$. The tube was sealed, evacuated, and back-filled with Ar. DMF (anhydrous, $1.0 \mathrm{~mL}$ ) was added and stirred for 15 minutes. In a separate $25 \mathrm{~mL}$ Teflon ${ }^{\mathrm{TM}}$ screw-cap culture tube, 2 (174 mg, $\left.0.25 \mathrm{mmol}\right)$ and di$t$ Bubipy (67 mg, $0.25 \mathrm{mmol}$ ) were dissolved in DMF under Ar. The solution containing the activated ester was then added via syringe to the solution of $\mathbf{2}$ and di$t$ Bubipy at rt. The color of the reaction mixture slowly turned from red-yellow to clear green. After $3 \mathrm{~h}$, the reaction was quenched with $1 \mathrm{M} \mathrm{HCl}(2 \mathrm{~mL})$, and $\mathrm{Et}_{2} \mathrm{O}$ was added. The organic layer was dried over $\mathrm{NaSO}_{4}$, filtered and concentrated. Column chromatography (hexanes:EtOAc 9:1) afforded $22 \mathrm{mg}$ (60\% yield) of compound 25 as a yellow oil. 

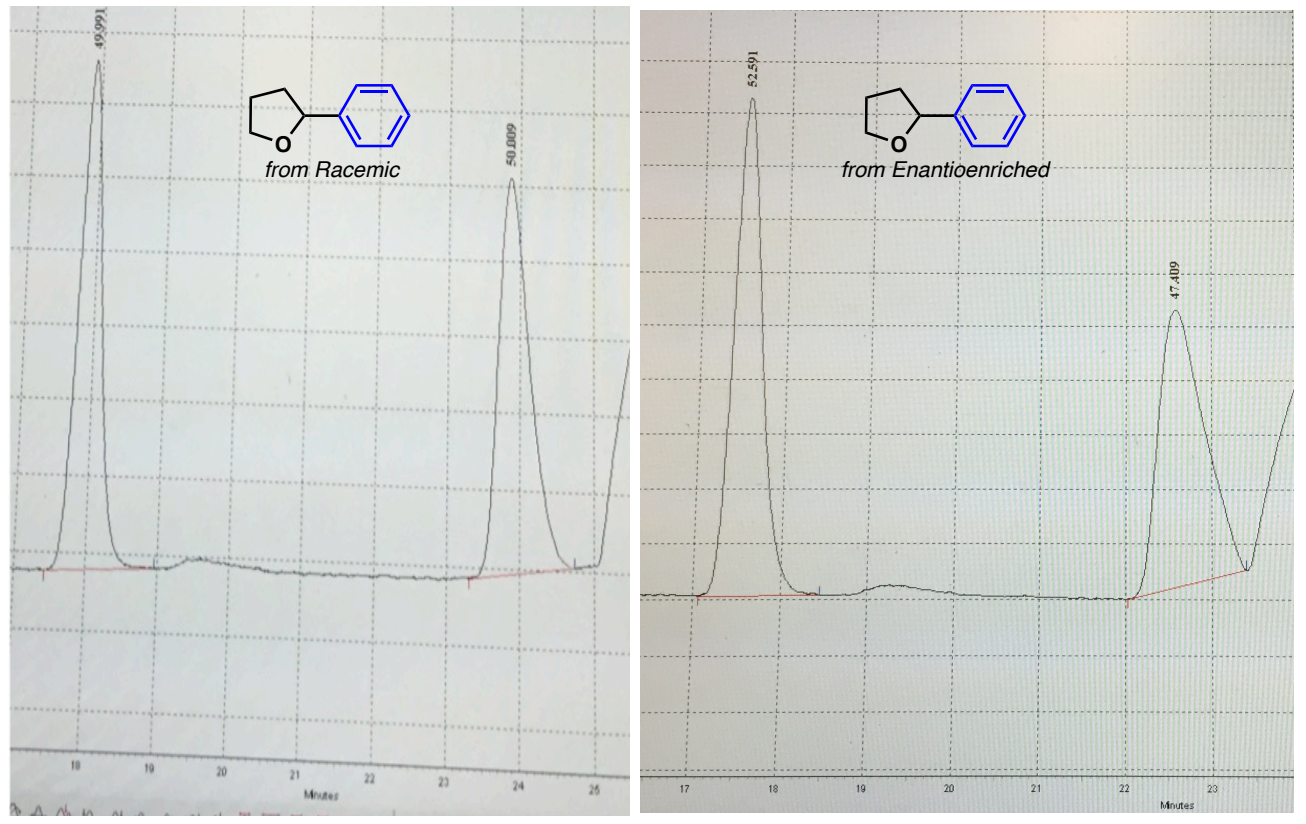

Left: HPLC chromatogram of $\mathbf{2 6}$ from the racemic acid. Right: from enantiopure acid.

Ring opening experiment<smiles>N[In]OC(=O)C1C(=O)C2CC1C1C[C@@H]2C1=O</smiles>

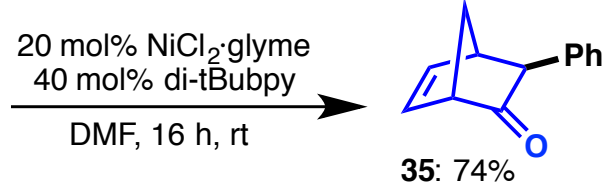

From $\mathrm{NiCl}_{2} \cdot$ glyme: Following the General Procedure B with 1,3-dioxoisoindolin-2-yl 5-oxotricyclo[2.2.1.0 $0^{2,6}$ heptane-3-carboxylate (59 mg, $\left.0.20 \mathrm{mmol}\right)$ and $\mathrm{PhZnCl} \cdot \mathrm{LiCl}$ complex (0.25 $\mathrm{M}$ in THF). Purification by column chromatography (pentane) afforded $25 \mathrm{mg}$ (74\%) of the rearranged product 35 .<smiles>O=C1C2C=CC(C2)C1c1ccccc1</smiles>

\section{3-Phenylbicyclo[2.2.1]hept-5-en-2-one}

Physical State: yellow oil.

$\boldsymbol{R}_{\boldsymbol{f}}=0.42$ (Hexanes:EtOAc 9:1).

${ }^{1}$ H NMR (400 MHz, CDCl $)$ ): $\delta 7.39-7.31(\mathrm{~m}, 4 \mathrm{H}), 7.31-7.19(\mathrm{~m}, 1 \mathrm{H}), 6.75(\mathrm{dd}, J$ $=5.6,2.8 \mathrm{~Hz}, 1 \mathrm{H}), 6.30(\mathrm{t}, J=4.4 \mathrm{~Hz}, 1 \mathrm{H}), 3.43(\mathrm{~s}, 1 \mathrm{H}), 3.26(\mathrm{~d}, J=3.5 \mathrm{~Hz}, 1 \mathrm{H})$, $3.17-3.06(\mathrm{~m}, 1 \mathrm{H}), 2.34(\mathrm{~d}, J=9.7 \mathrm{~Hz}, 1 \mathrm{H})$, and $2.29-2.17(\mathrm{~m}, 1 \mathrm{H})$. 
${ }^{13}$ C NMR (101 MHz, $\left.\mathbf{C D C l}_{3}\right): \delta$ 214.1, 143.7, 138.1, 132.9, 128.5, 127.8, 126.6, 55.6, 49.3, 47.3, and 46.0.

HRMS (ESI-TOF): calc'd for $\mathrm{C}_{15} \mathrm{H}_{13} \mathrm{O}[\mathrm{M}+\mathrm{H}]^{+}$185.0961; found 185.0961.

\section{TEMPO experiment}

An oven-dried test tube containing a stirring bar was charged with $\mathrm{NiCl}_{2} \cdot$ glyme (20 mol \%), di-tBubipy (40 mol \%), TEMPO (39 mg, $0.1 \mathrm{mmol})$, and 2-ethylhexanoic phthalimide ester $(0.1 \mathrm{mmol}, 1.0$ equiv). The tube was sealed evacuated and backfilled with Ar. DMF was then added via syringe and the mixture stirred for 2 minutes at $\mathrm{rt}$. Then, $\mathrm{PhZnCl} \cdot \mathrm{LiCl}(0.21 \mathrm{M}$ in THF) was added at $\mathrm{rt}$ and the mixture was stirred for $14-16 \mathrm{~h}$ at $\mathrm{rt}$. The mixture was then diluted with EtOAc $(2 \mathrm{~mL})$ and a solution of $\mathrm{HCl}(1 \mathrm{M})$. No trace of product 3 was detected after evaporation of the organic layer and analysis using GC/MS).

\section{Photocatalysis and Nickel catalysis}

A $50 \mathrm{~mL}$ pyrex glass high-pressure tube was charged with $\left(\operatorname{Ir}\left[\mathrm{dF}\left(\mathrm{CF}_{3}\right) \mathrm{ppy}\right]_{2}(\mathrm{dtbpy})\right) \mathrm{PF}_{6}(4.5 \mathrm{mg}, 0.004 \mathrm{mmol}), \mathrm{NiCl}_{2} \cdot \mathrm{glyme}(8.8 \mathrm{mg}, 0.04$ mmol), di-tert-butylbipyridine (16 mg, $0.06 \mathrm{mmol}$ ), 4-chloro-1-iodobenzene (95 mg, $0.4 \mathrm{mmol})$, anhydrous $\mathrm{Cs}_{2} \mathrm{CO}_{3}(195 \mathrm{mg}, 0.6 \mathrm{mmol})$ and 2-ethylhexanoic acid (0.6 mmol) and dissolved in $20 \mathrm{~mL}$ of anhydrous DMF. The mixture was then sparged with Ar for 30 minutes and then sealed under Ar. The tube was then placed in a stirring plate and irradiated with two $60 \mathrm{~W}$ lamps for 3 days $(72 \mathrm{~h})$. After this time, the mixture was quenched with $\mathrm{Na}_{2} \mathrm{CO}_{3}$ saturated and extracted with $\mathrm{Et}_{2} \mathrm{O}(20 \mathrm{~mL} \mathrm{x}$ 4). No trace of product $\mathbf{8}$ was detected after evaporation of the organic layer and analysis by GC/MS and NMR. 


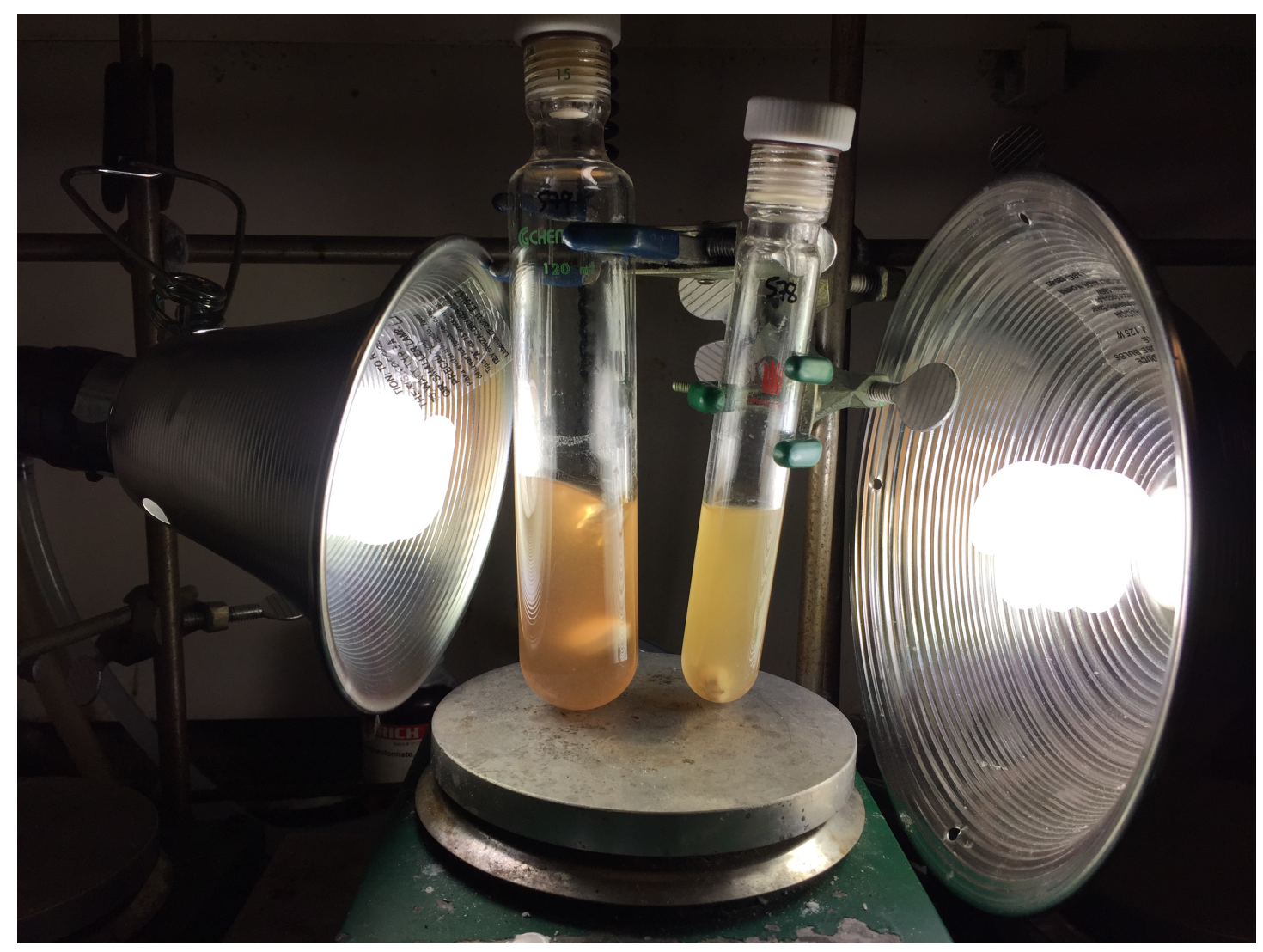

(Left) Performed with $0.8 \mathrm{mmol}$ of aryl iodide (40 mL DMF). Right: reaction performed with 0.4 mmol of aryl iodide (20 mL DMF). 
Alternative mechanism for the Ni-catalyzed decarboxylative arylation of secondary carboxylic activated esters and arylzinc reagents.

A. Bimetallic

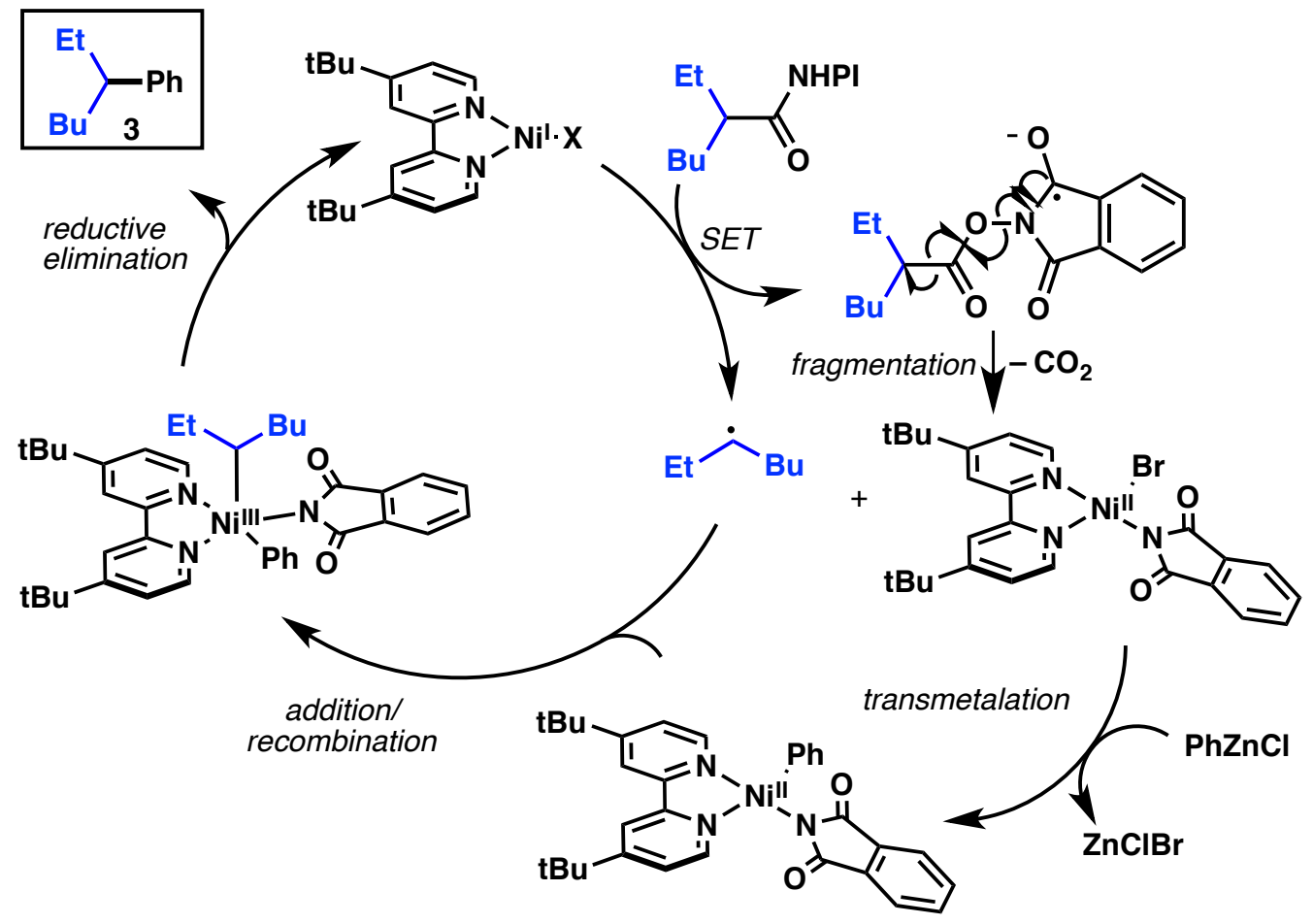

At present, a putative mechanism based on a bimetallic system where $\mathrm{Ni}(\mathrm{I})$ species act as radical carrier as proposed by $\mathrm{Fu}$ et al could not be ruled out. ${ }^{8}$

\section{Differential Scanning Calorimetry of NHPI-Esters.}

Both esters were stable well within the reaction operating ranges. The cyclopentyl substrate showed a small onset at $145.76 \mathrm{deg} C(32.76 \mathrm{~J} / \mathrm{g})$, then a much larger one at $213.98{ }^{\circ} \mathrm{C}(821.8 \mathrm{~J} / \mathrm{g})$. The exact melting point was at $71.14^{\circ} \mathrm{C}$. The 2-ethylhexanoyl substrate showed a similar pattern; a small onset at $176.28^{\circ} \mathrm{C}(24.17 \mathrm{~J} / \mathrm{g})$, then a larger one at $283.34{ }^{\circ} \mathrm{C}(801.7 \mathrm{~J} / \mathrm{g})$. 
DSC

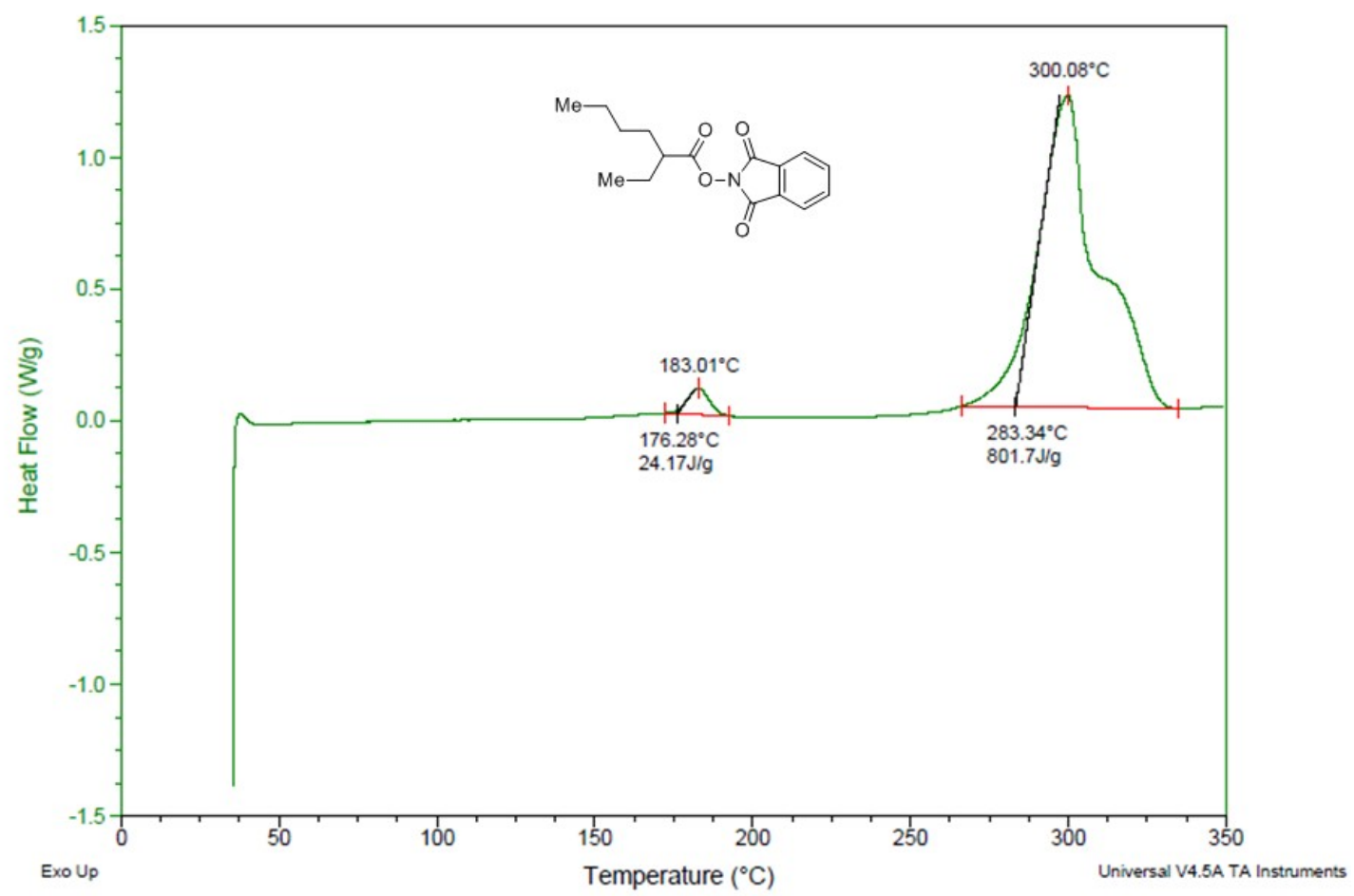

DSC

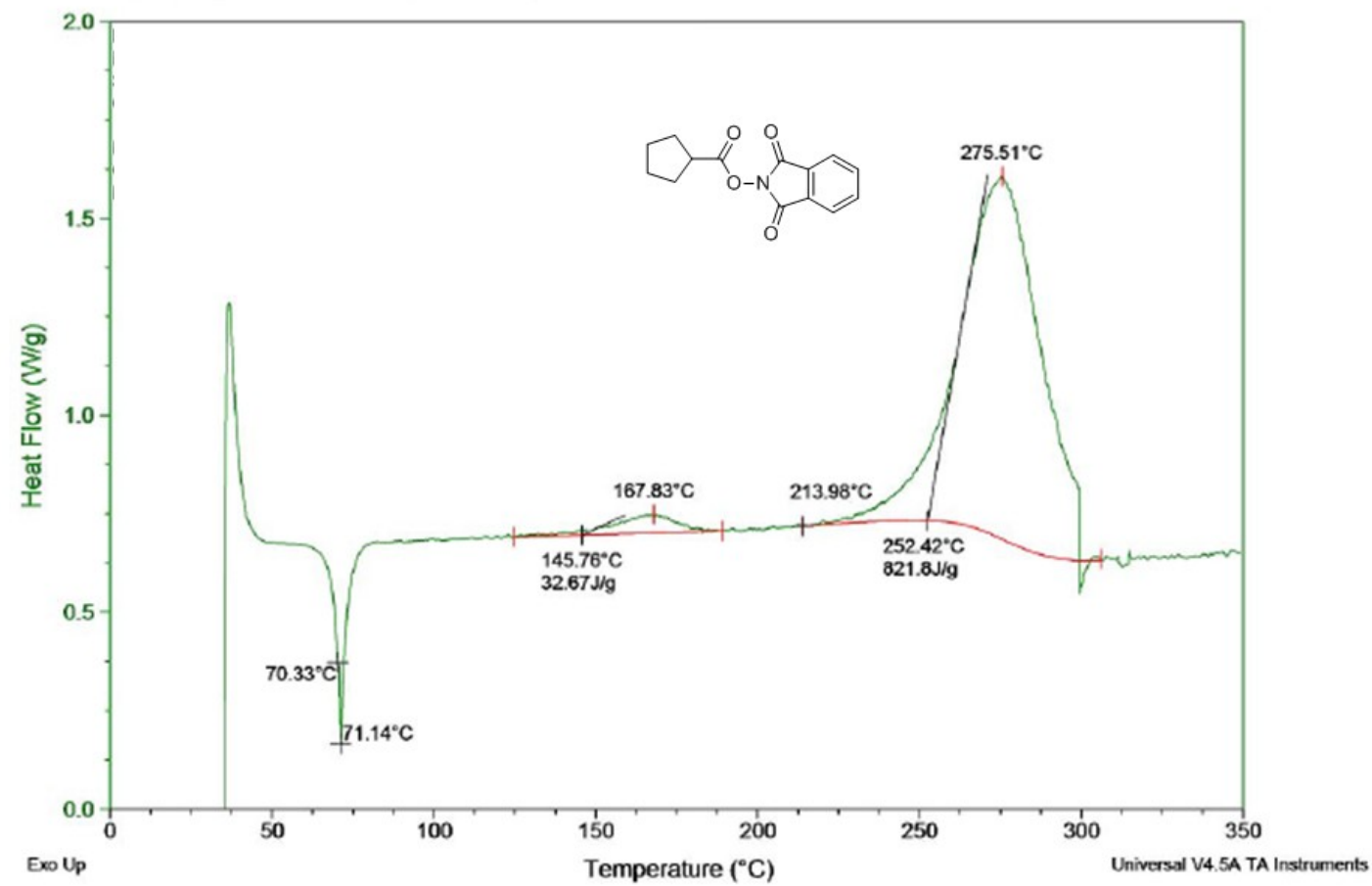


NMR Spectra<smiles>CCC(Br)C(=O)On1ccccc1=S</smiles>

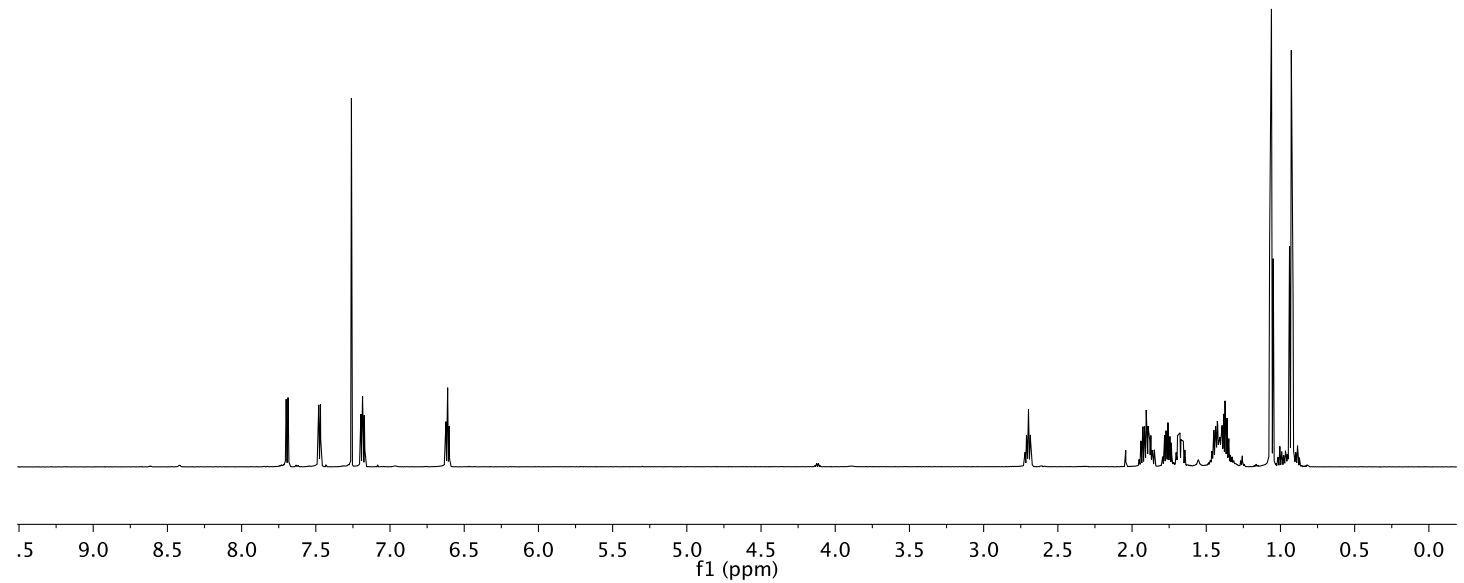<smiles>CCC(Br)C(=O)On1ccccc1=S</smiles>

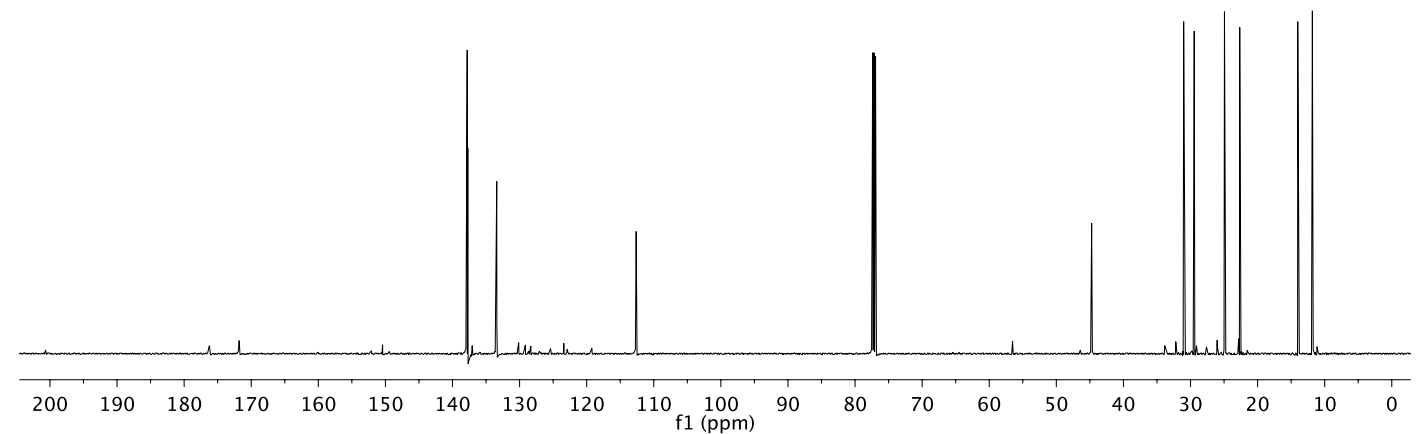



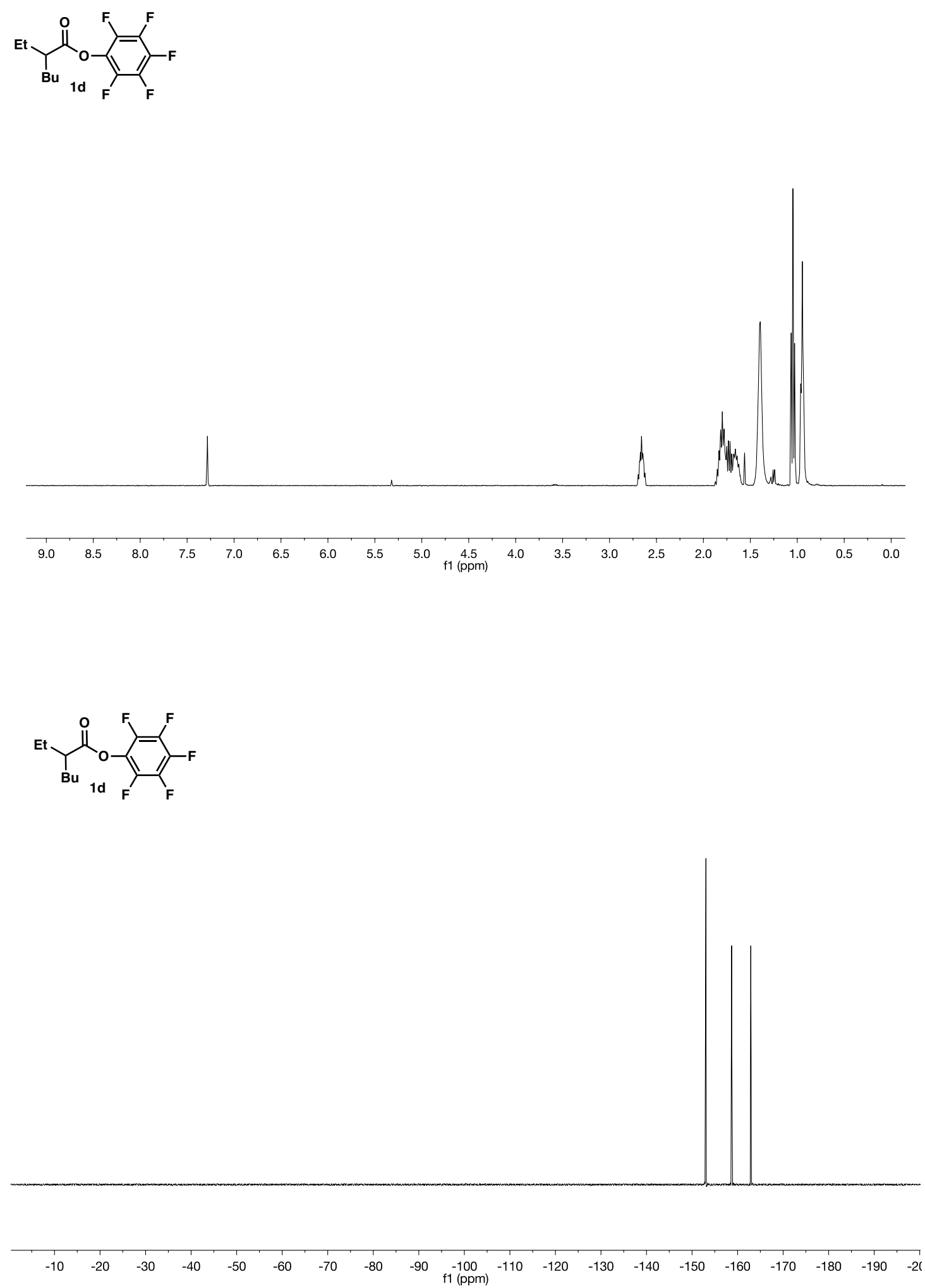


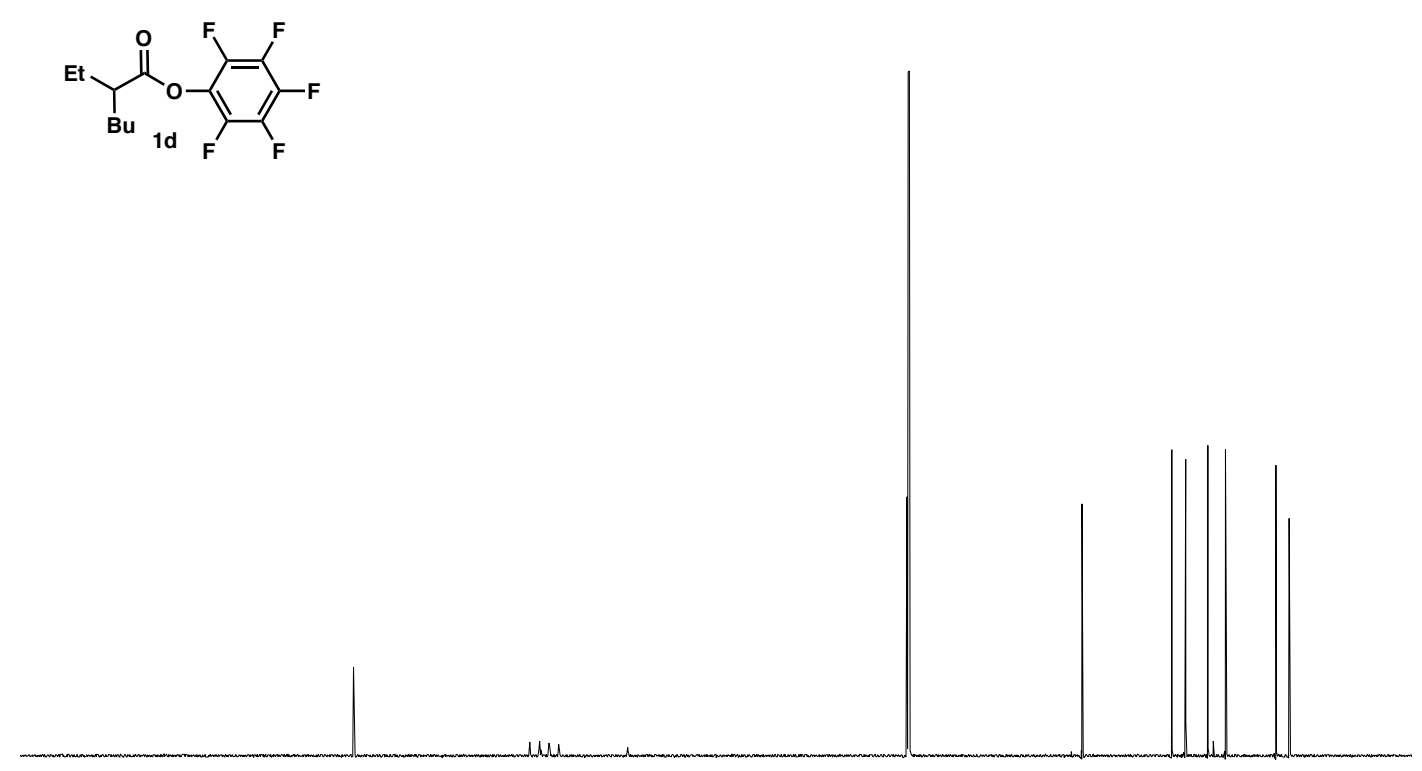

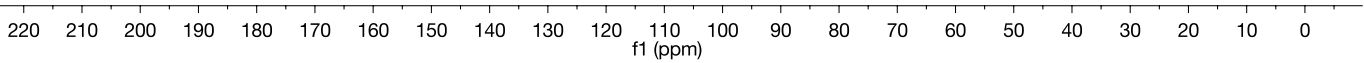<smiles>CCC(Br)C(=O)ON1C(=O)CCC1=O</smiles>

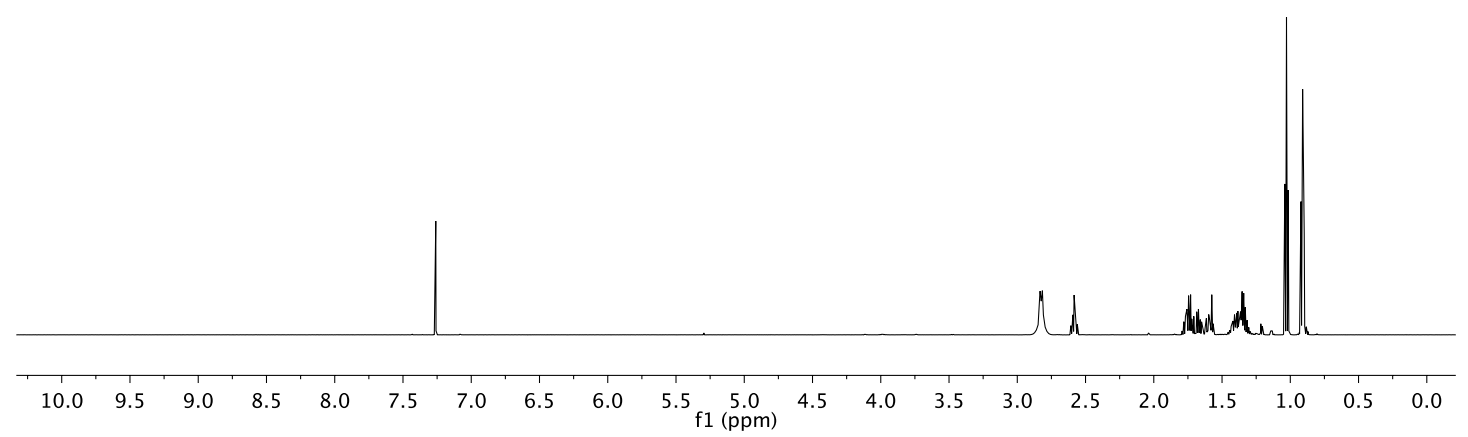




$$
x
$$
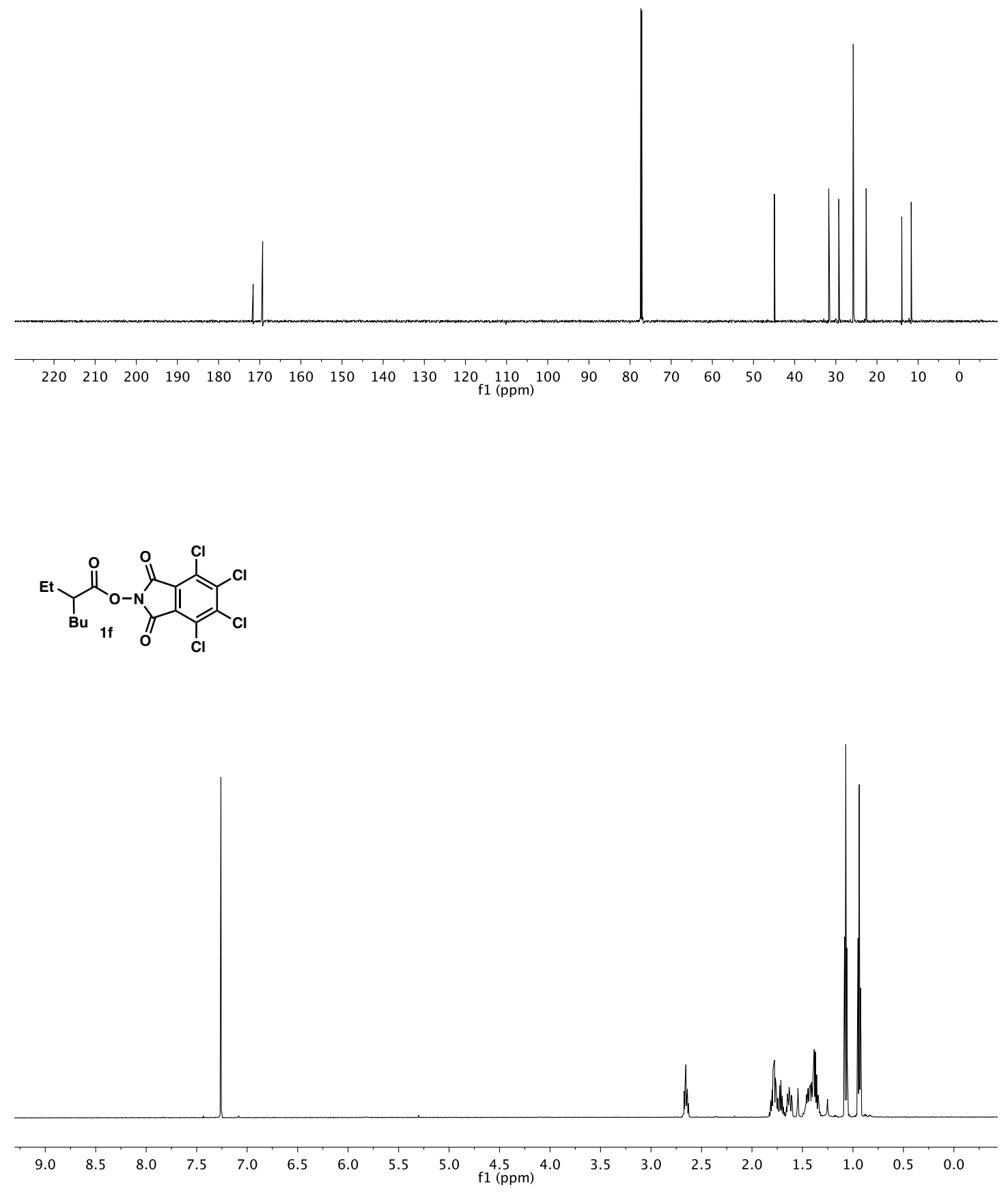

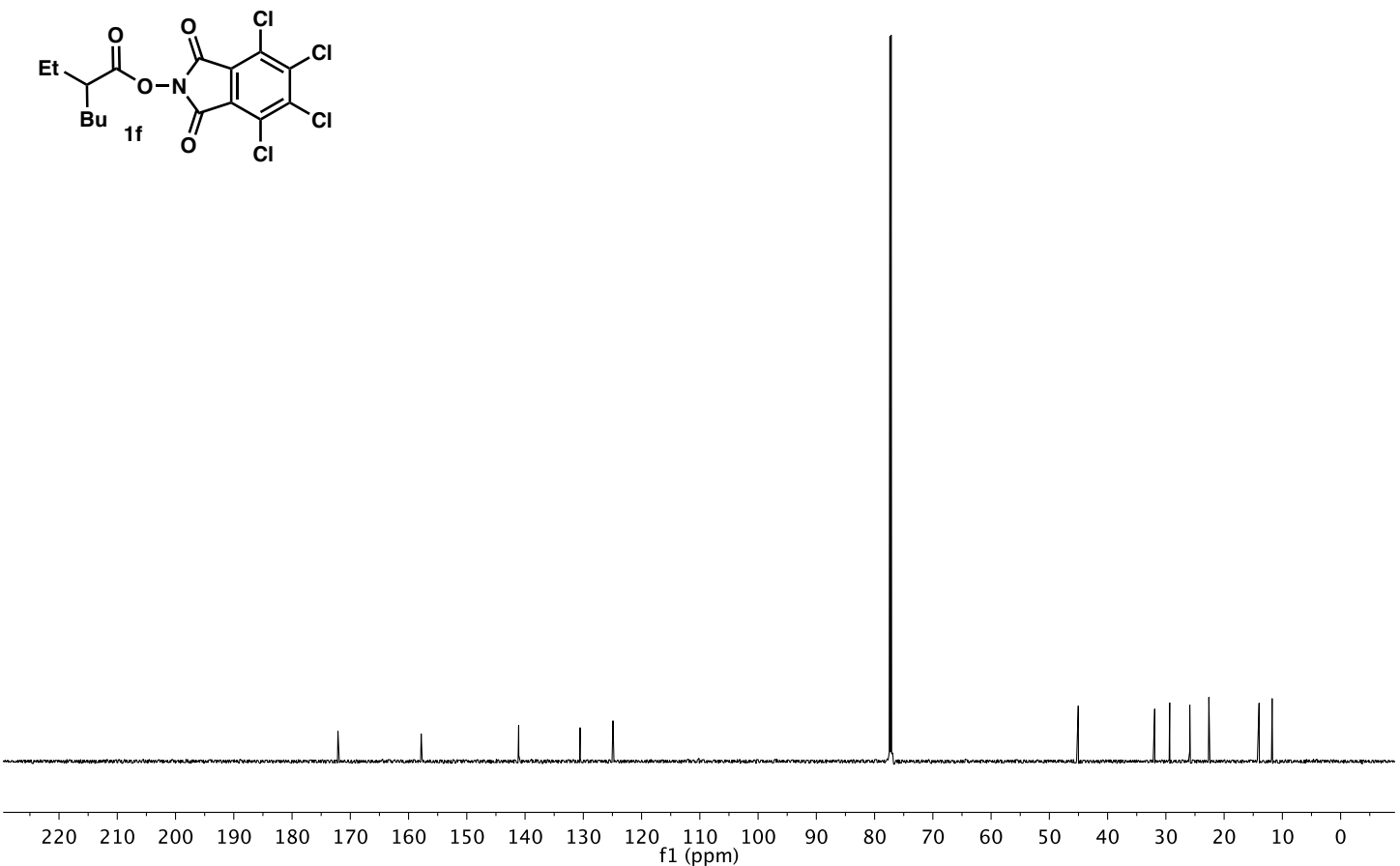<smiles>CCC(Br)C(=O)ON1C(=O)c2ccccc2C1=O</smiles>
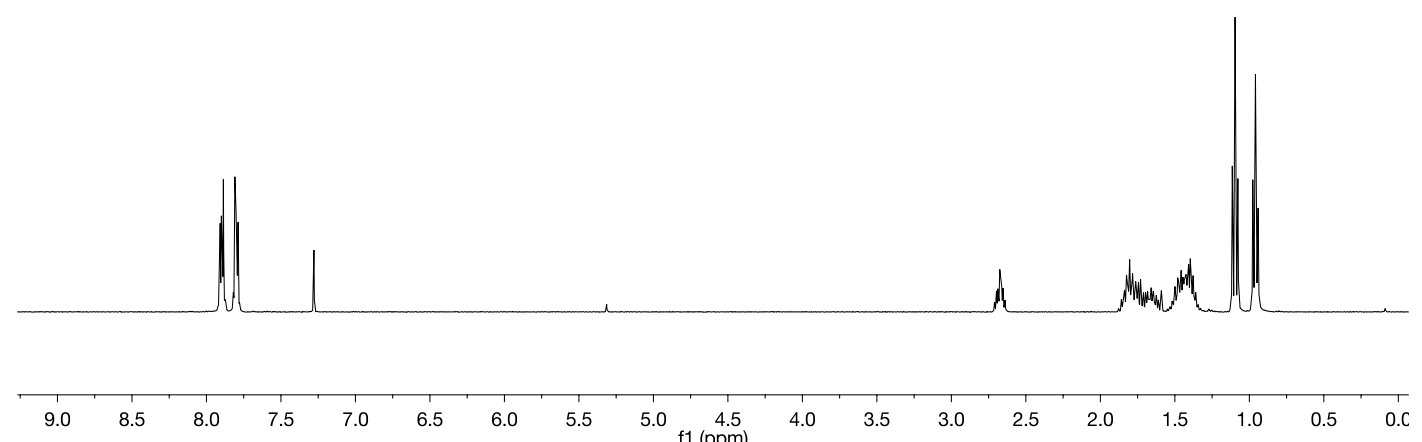

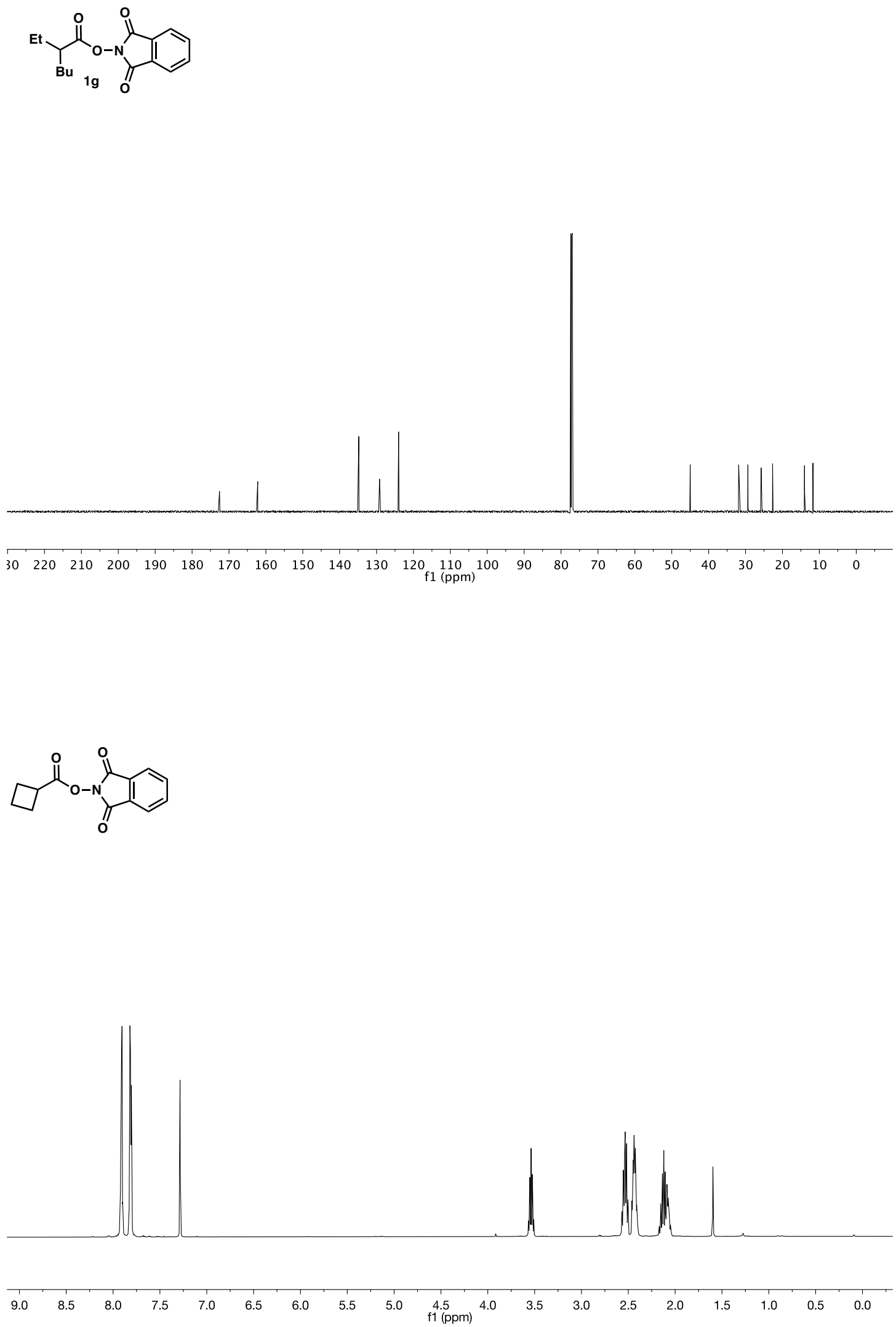

S70 


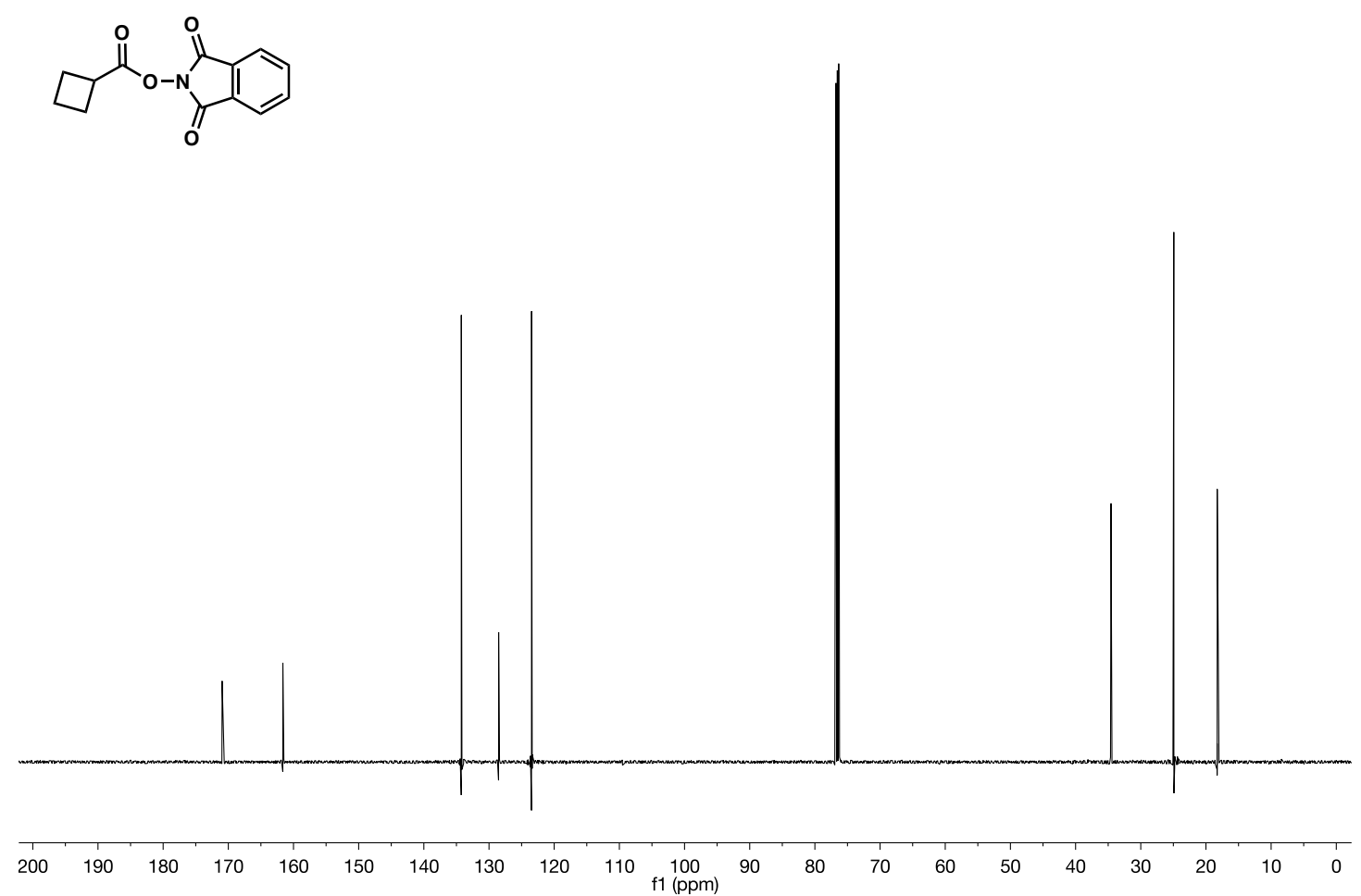

$\mathrm{U}^{\mathrm{O}}$

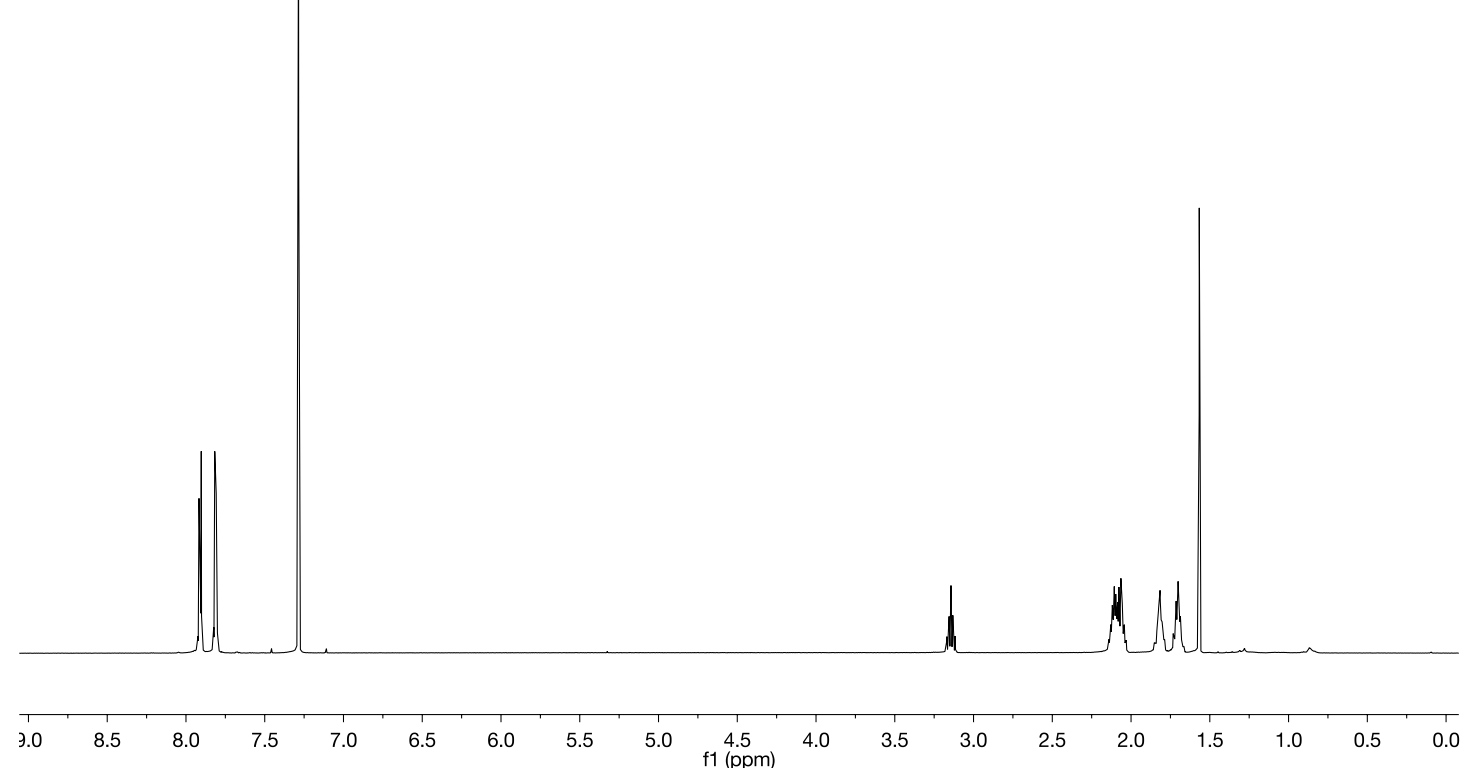


<smiles>O=C(ON1C(=O)c2ccccc2C1=O)C1CCCC1</smiles>

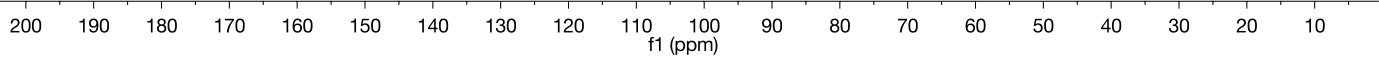<smiles>O=C(ON1C(=O)c2ccccc2C1=O)C1CCCCC1</smiles>

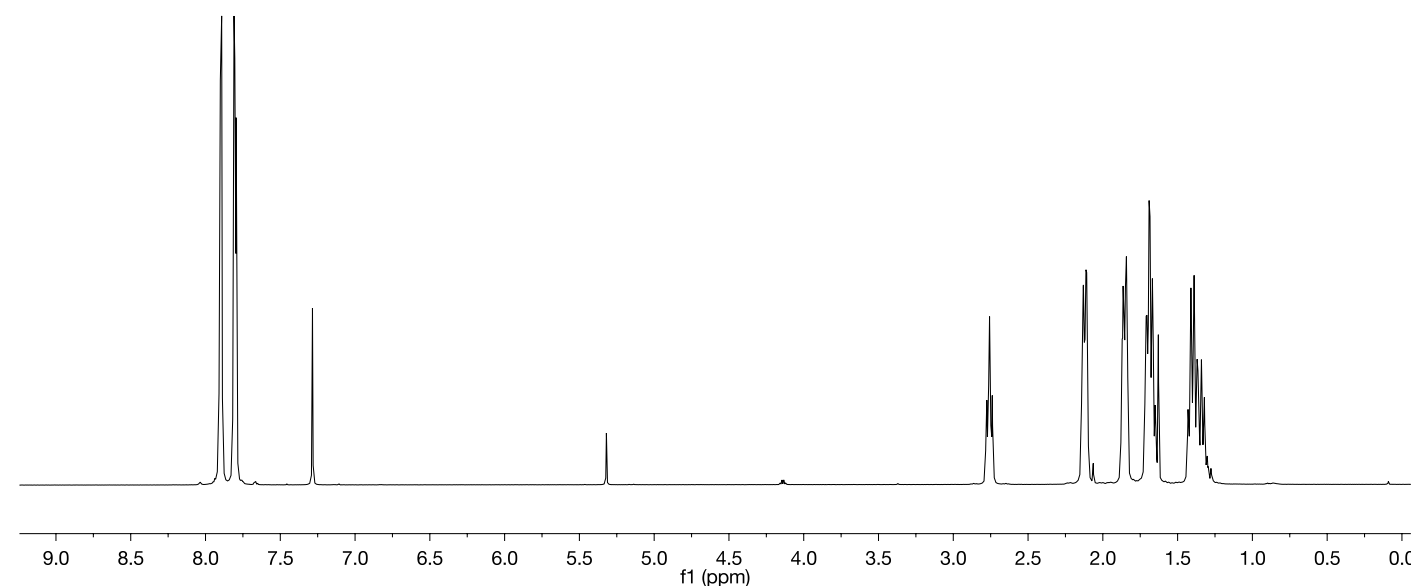



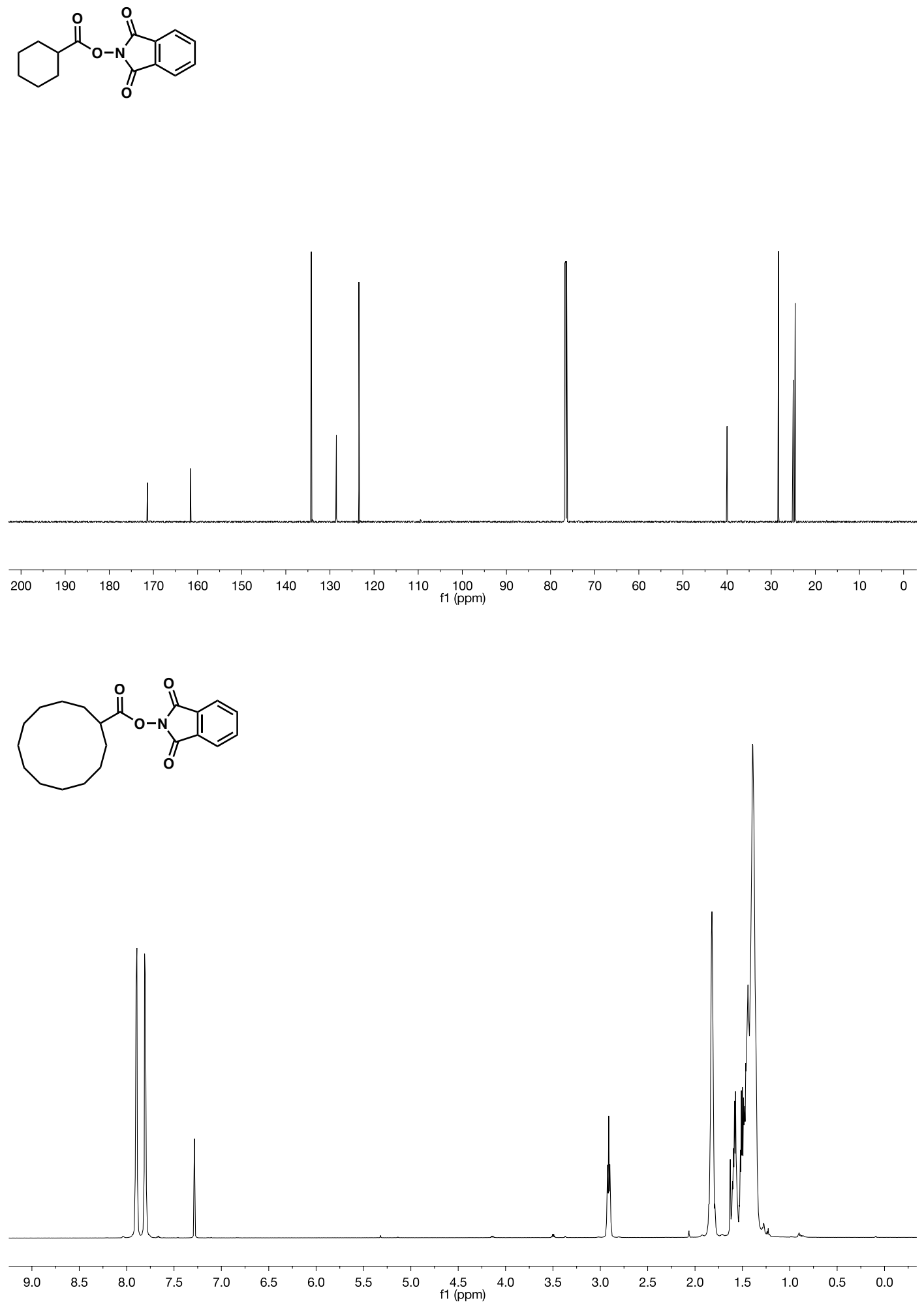

S73 

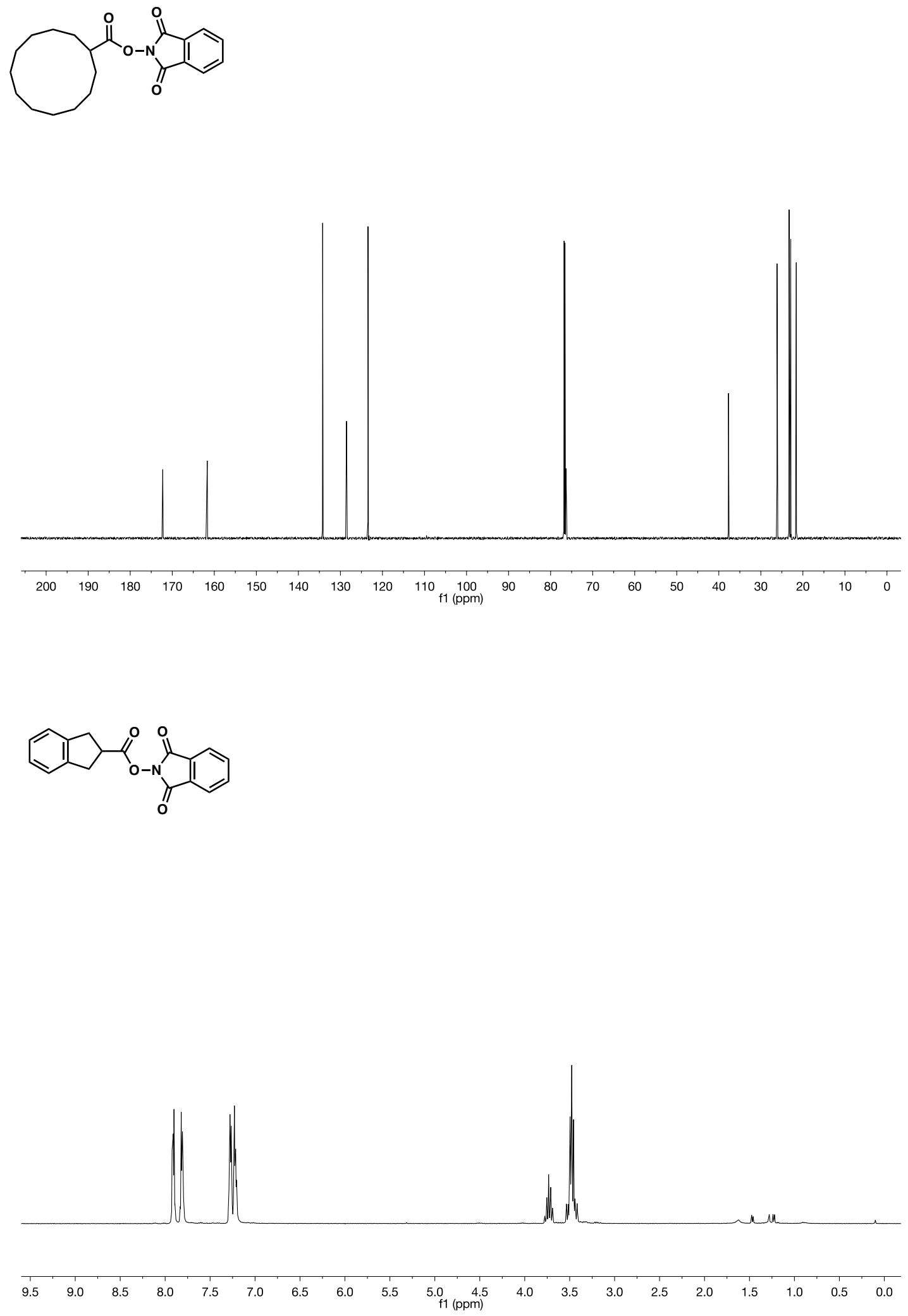

S74 


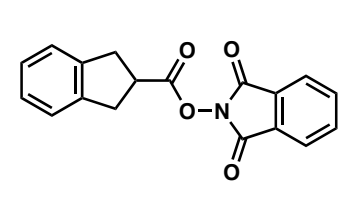
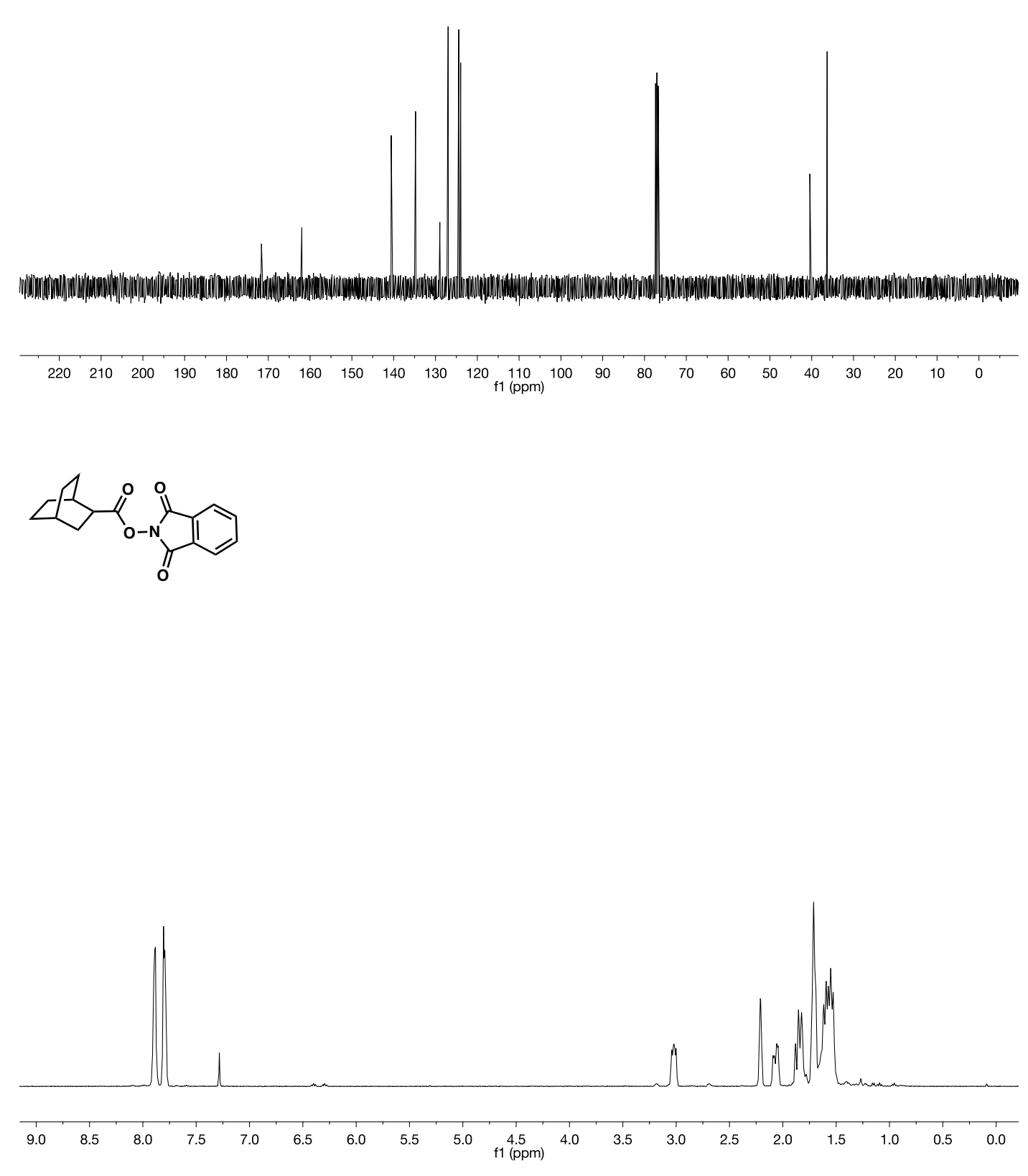

S75 
$A-1$

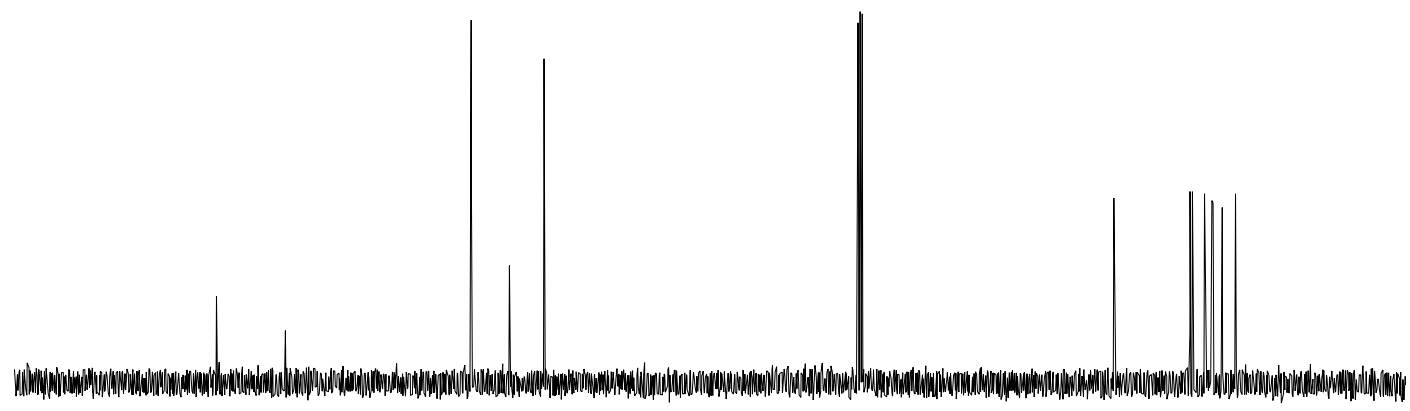

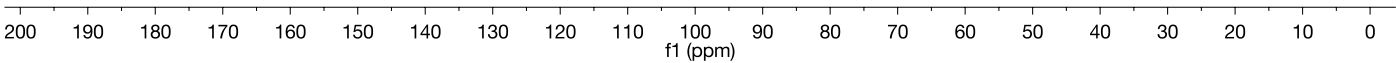<smiles>O=C(ON1C(=O)c2ccccc2C1=O)C1CC2C=CC1C2</smiles>

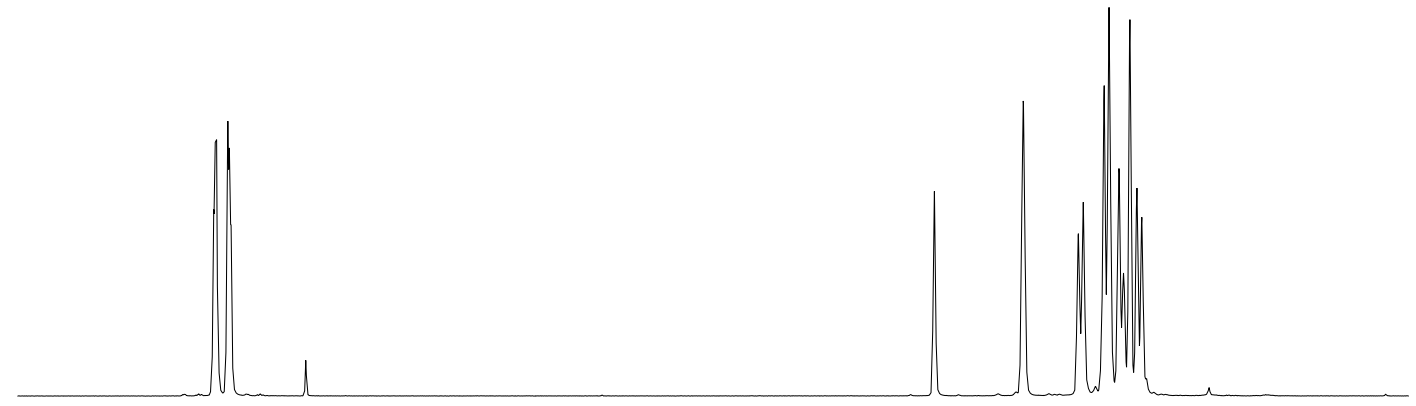

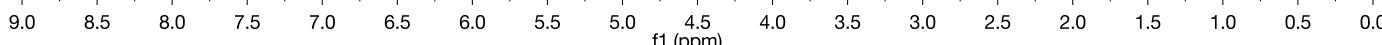



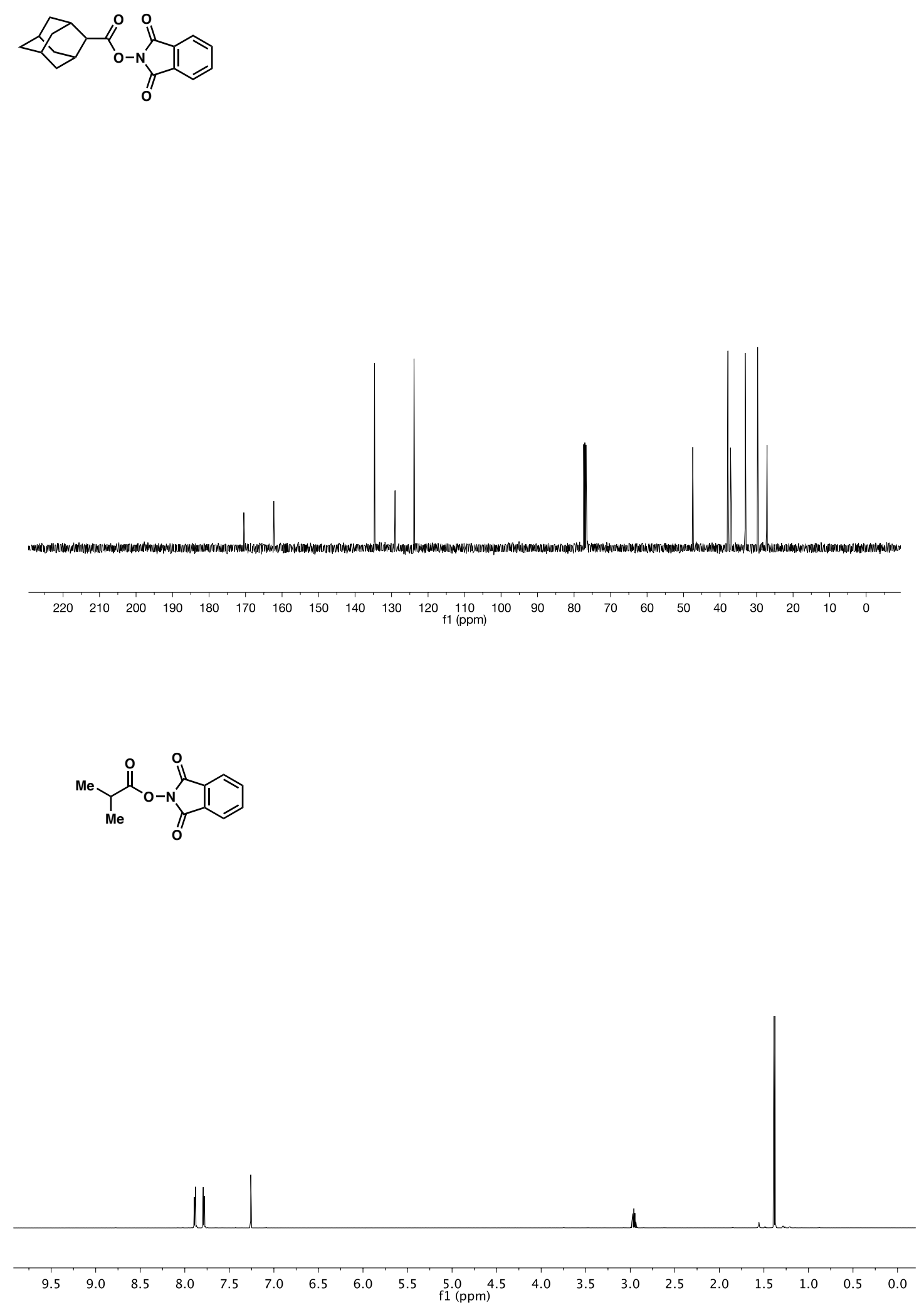

S77 

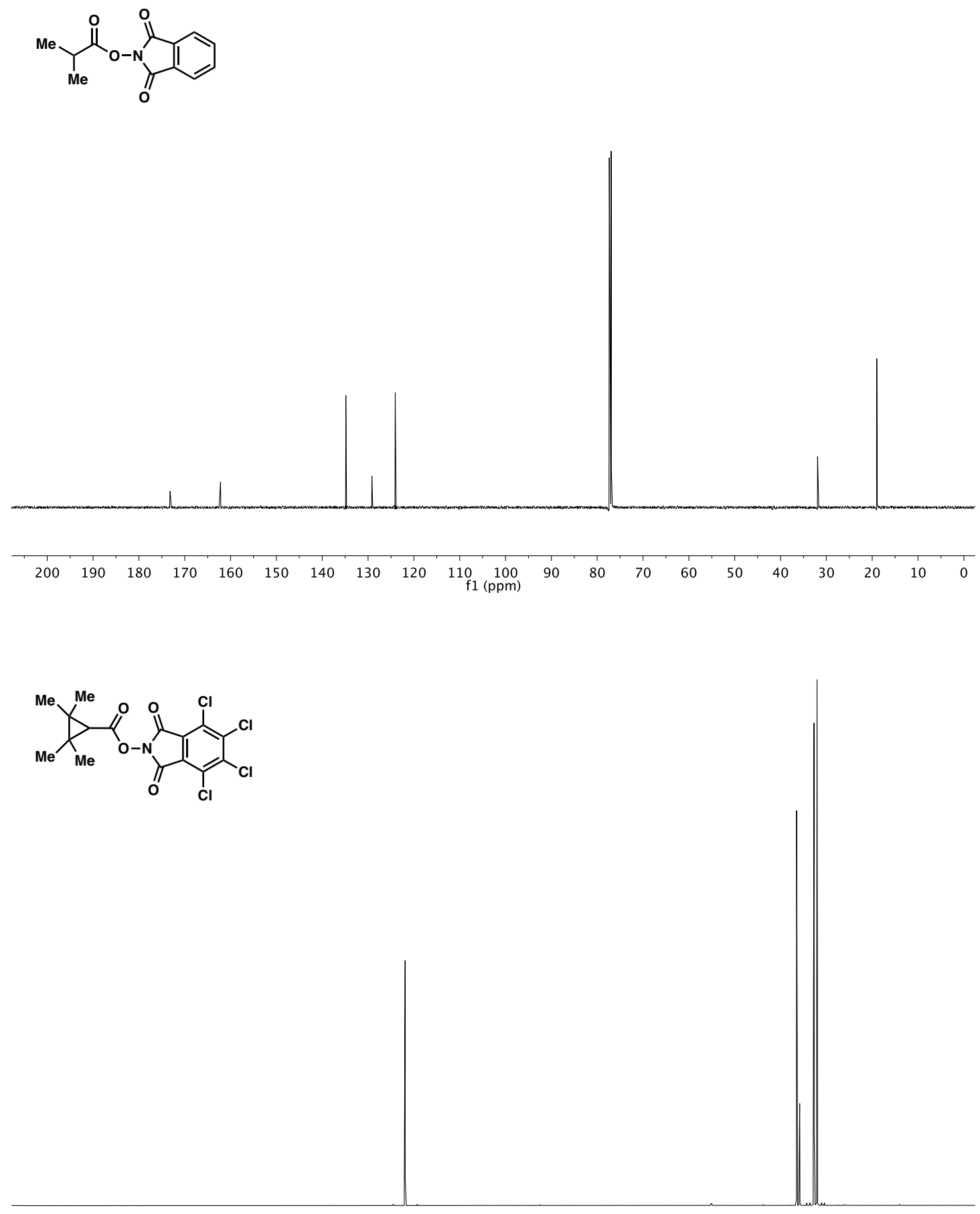

\begin{tabular}{lllllllllllllllllllllllllllllllllll}
\hline 3.0 & 12.5 & 12.0 & 11.5 & 11.0 & 10.5 & 10.0 & 9.5 & 9.0 & 8.5 & 8.0 & 7.5 & 7.0 & 6.5 & 6.0 & 5.5 & 5.0 & 4.5 & 4.0 & 3.5 & 3.0 & 2.5 & 2.0 & 1.5 & 1.0 & 0.5 & 0.0 & -0.5 & -1
\end{tabular}

S78 

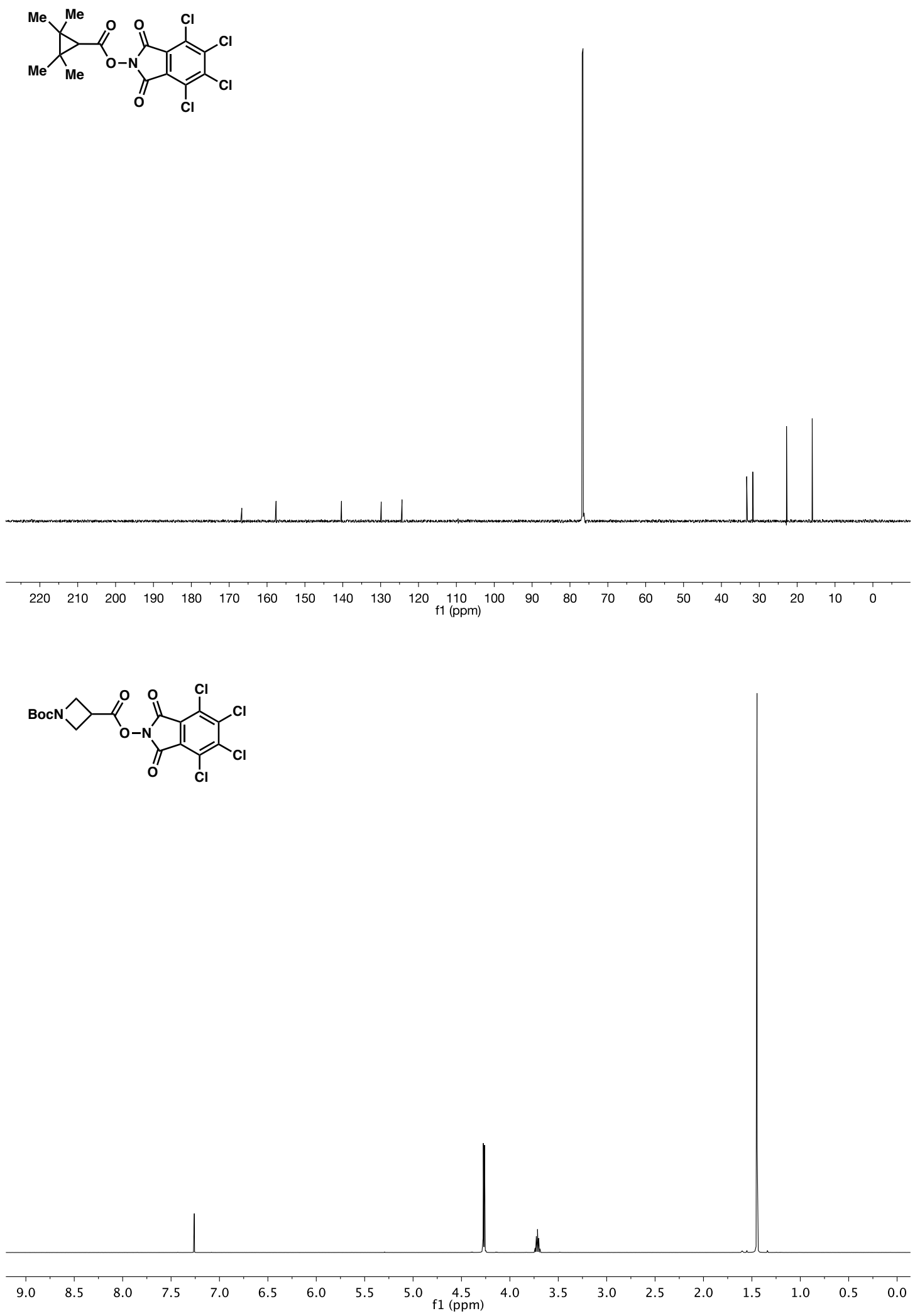

S79 

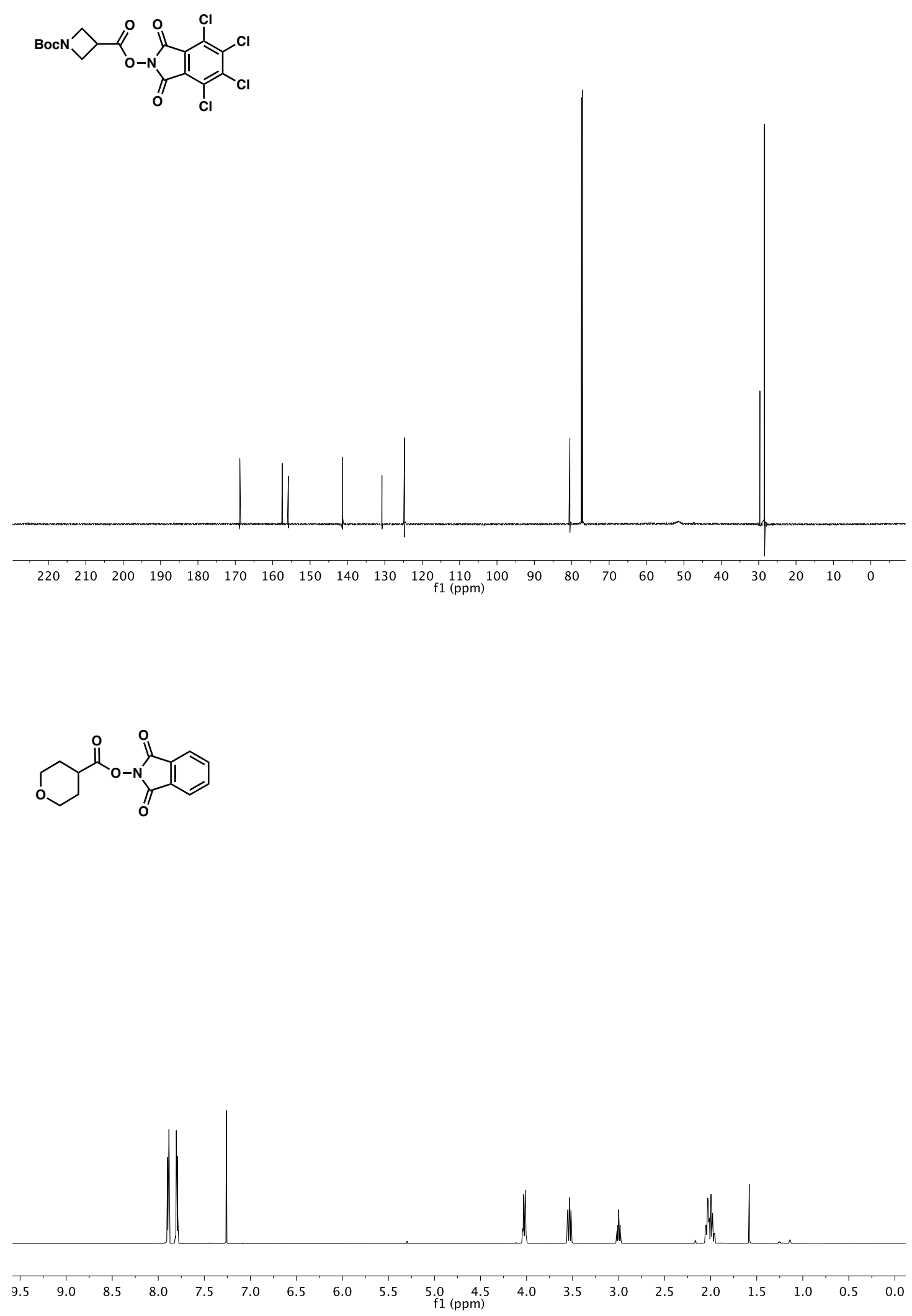

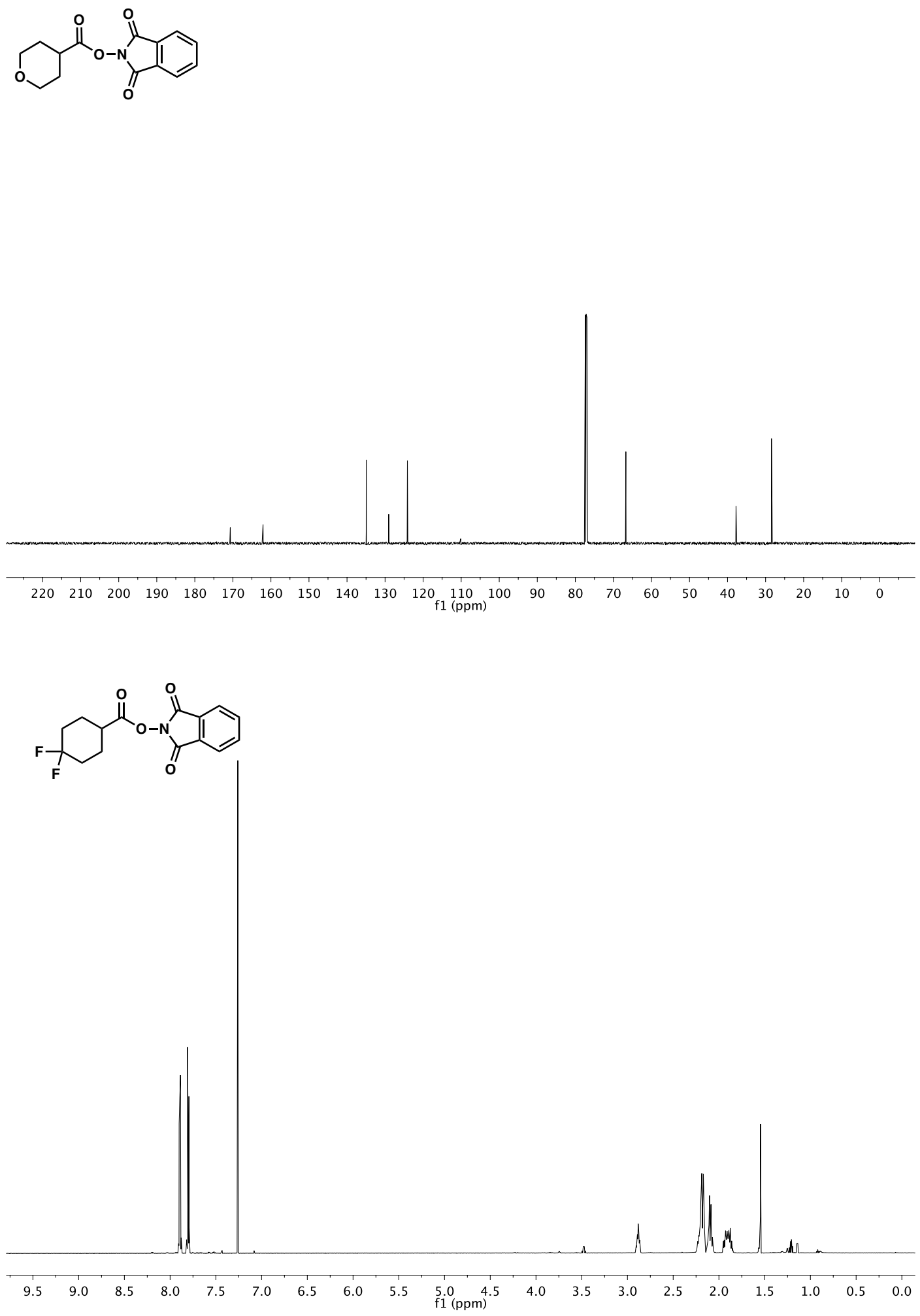

S81 

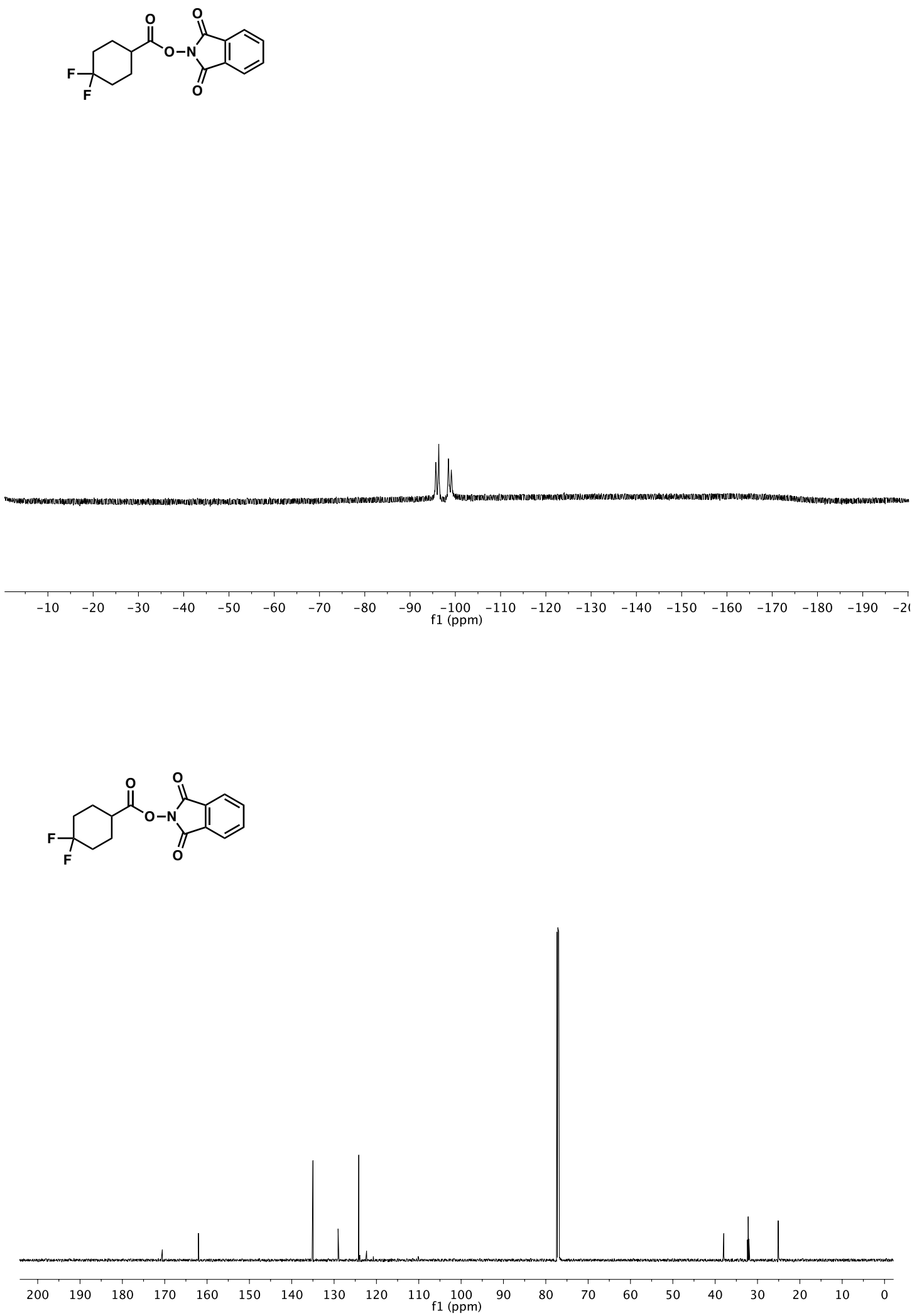

S82 

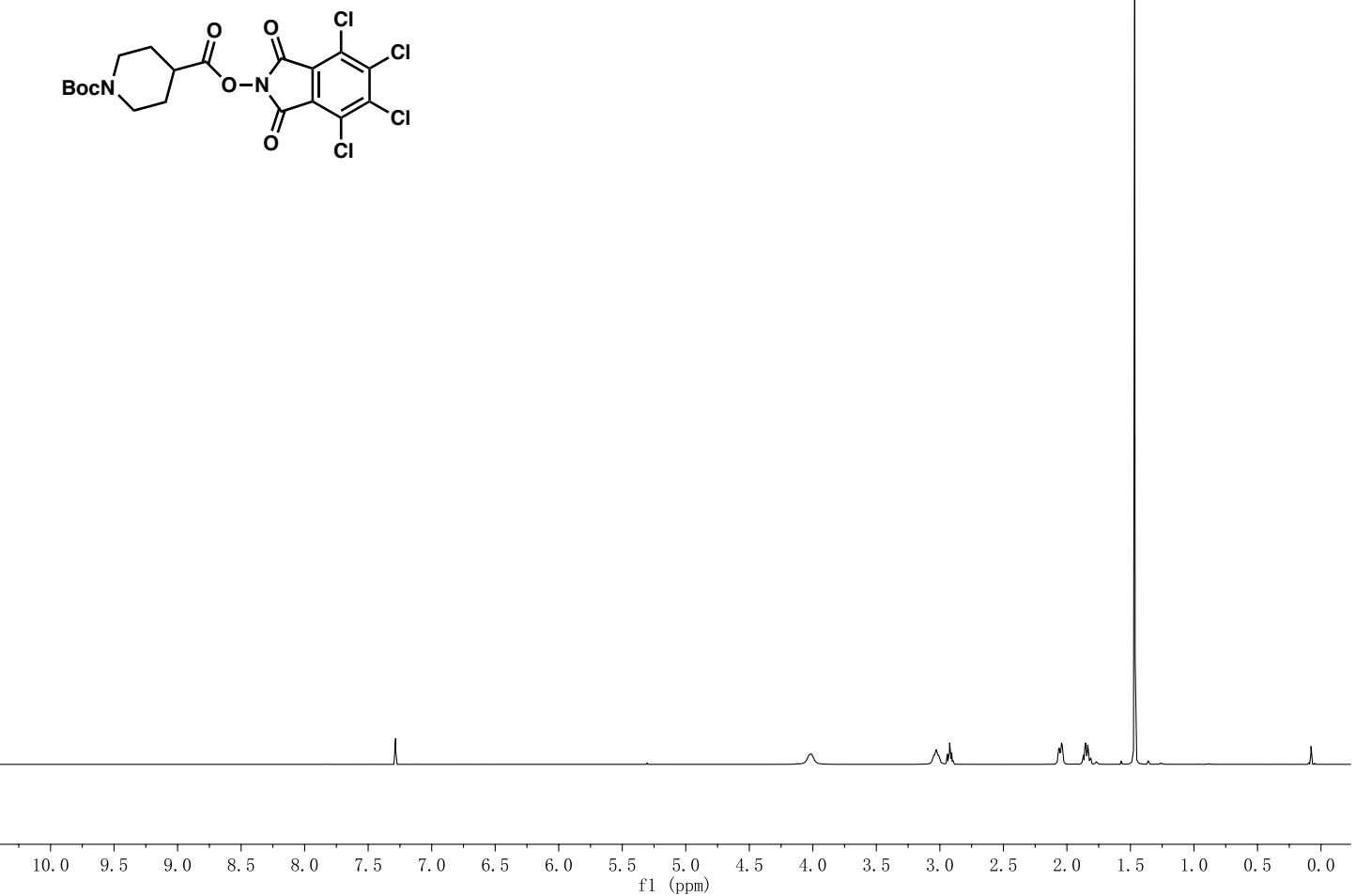

(c)

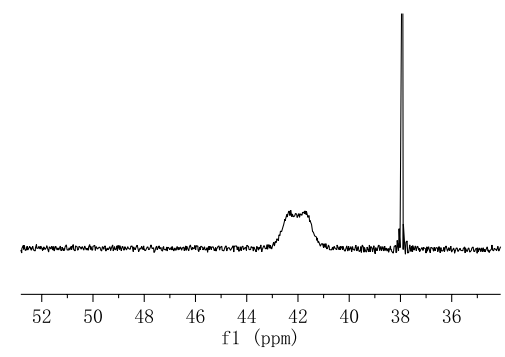

$\begin{array}{lllllllllll}210 & 200 & 190 & 180 & 170 & 160 & 150 & 140 & 130 & 120 & 110 \\ \mathrm{f} 1 & (\mathrm{p} p)\end{array}$ 

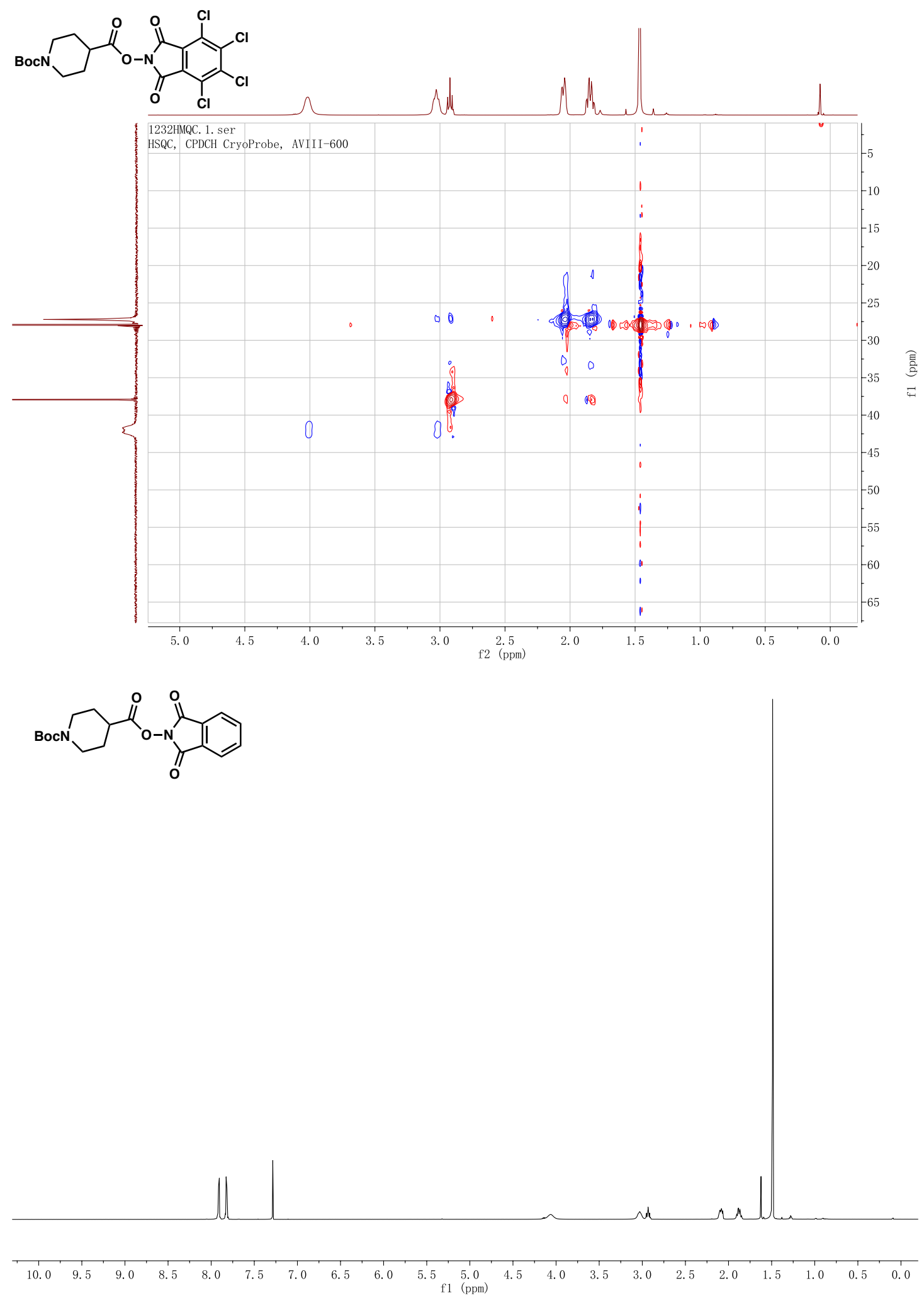

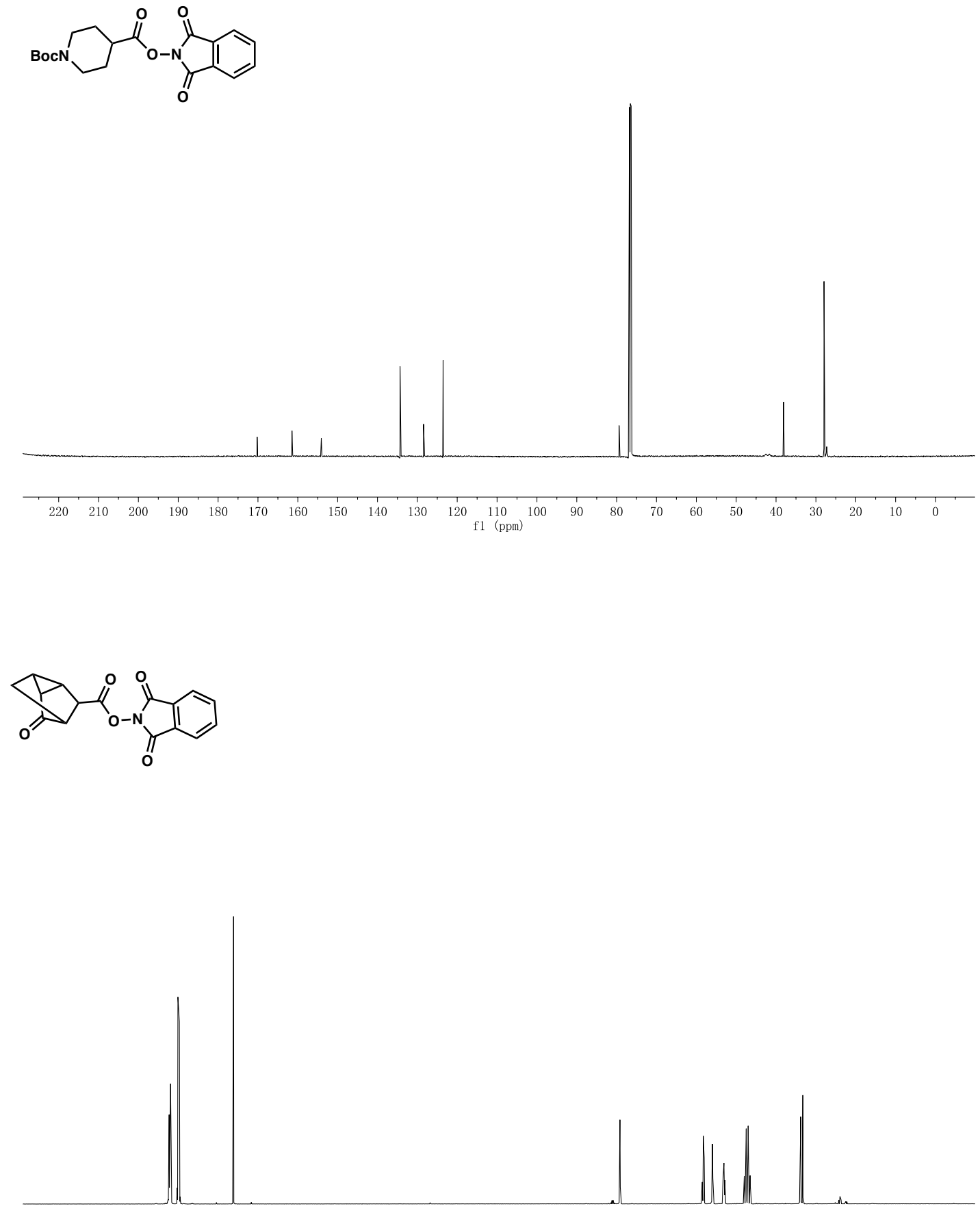

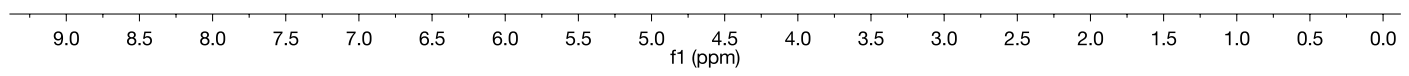

S85 

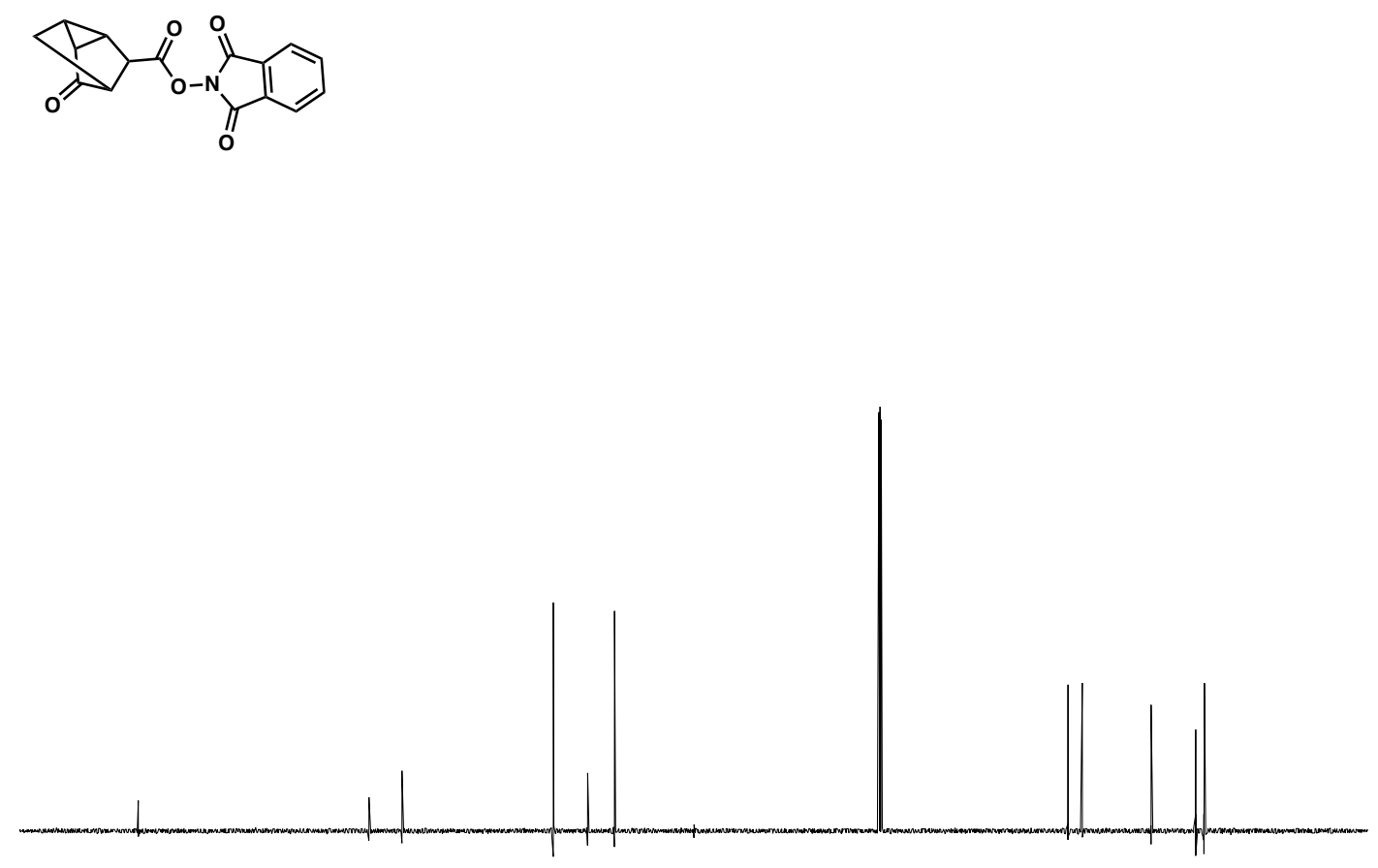

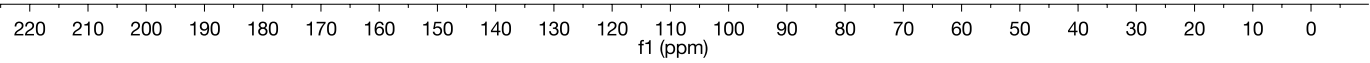<smiles>CC(C)COC(C)CC(C)C(=O)ON1C(=O)c2ccccc2C1=O</smiles>

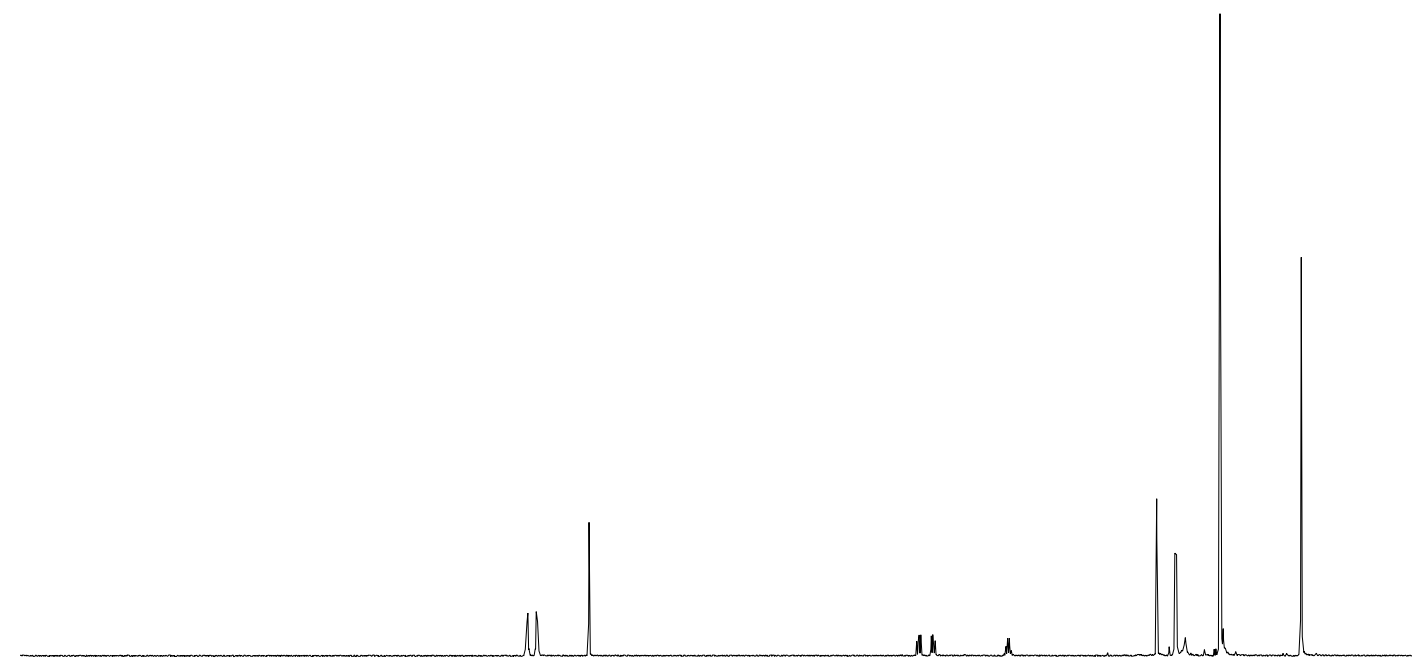

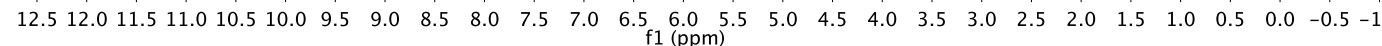



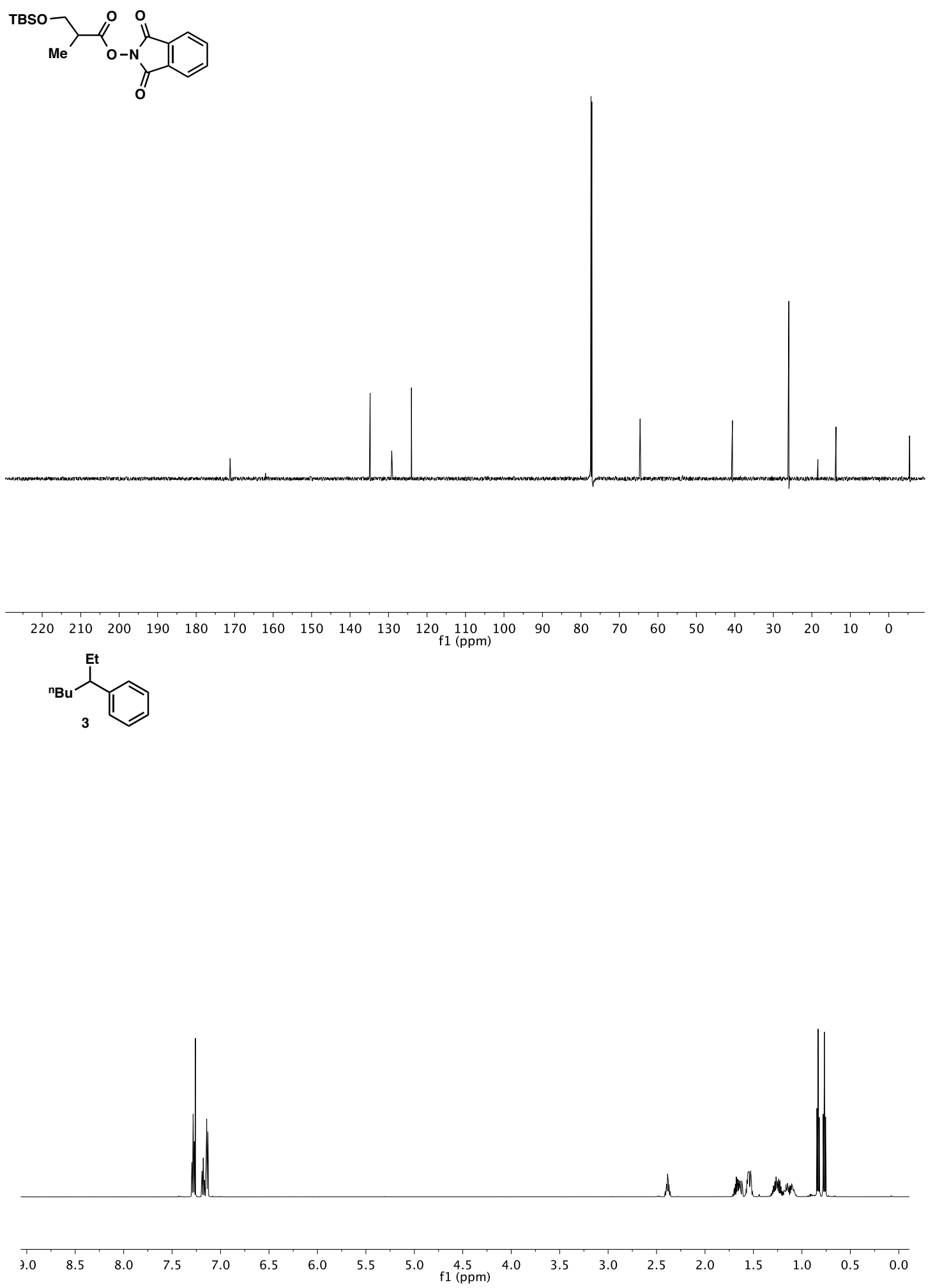

S87 

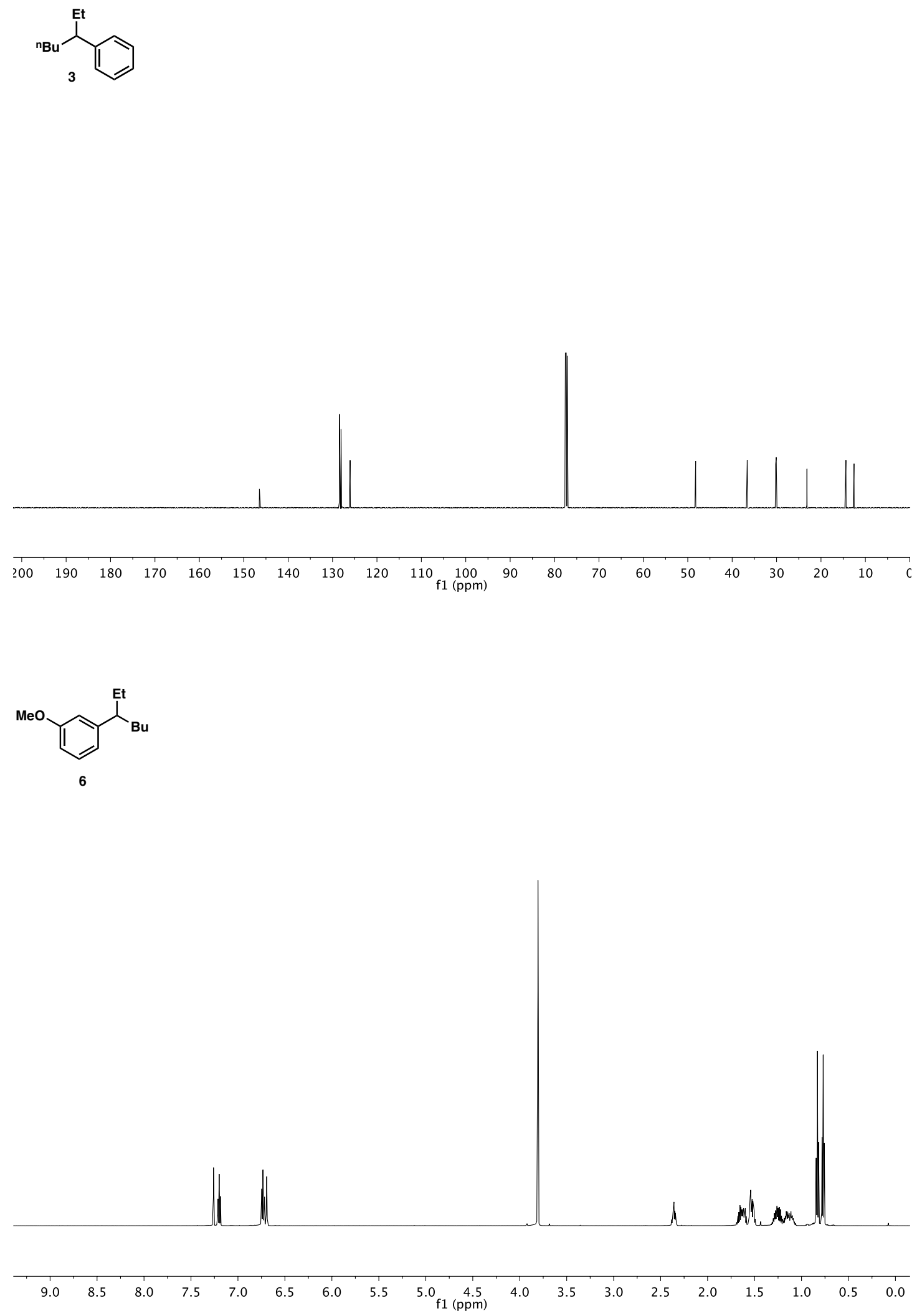

S88 
<smiles>CCC(CC)c1cccc(OC)c1</smiles>
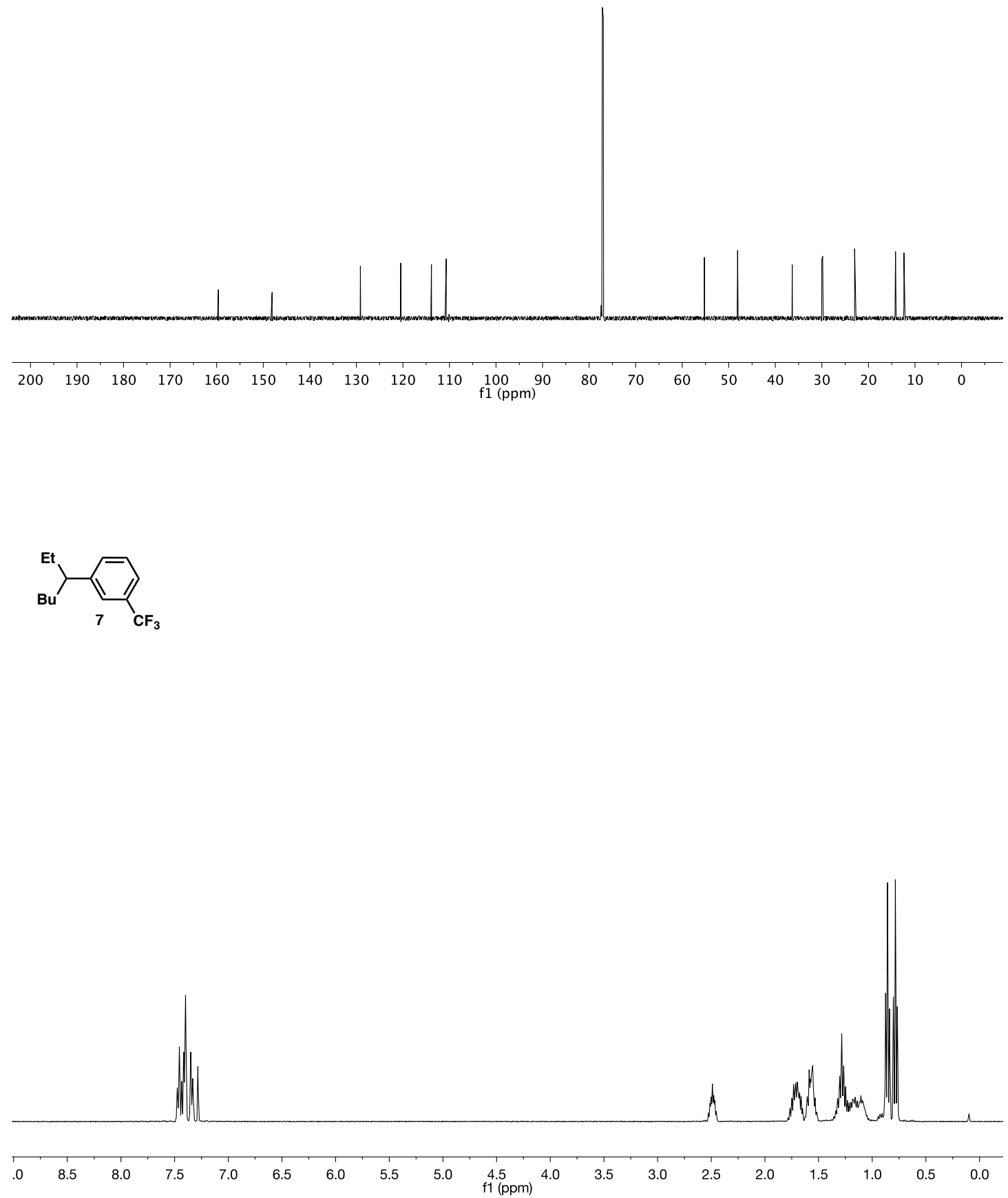

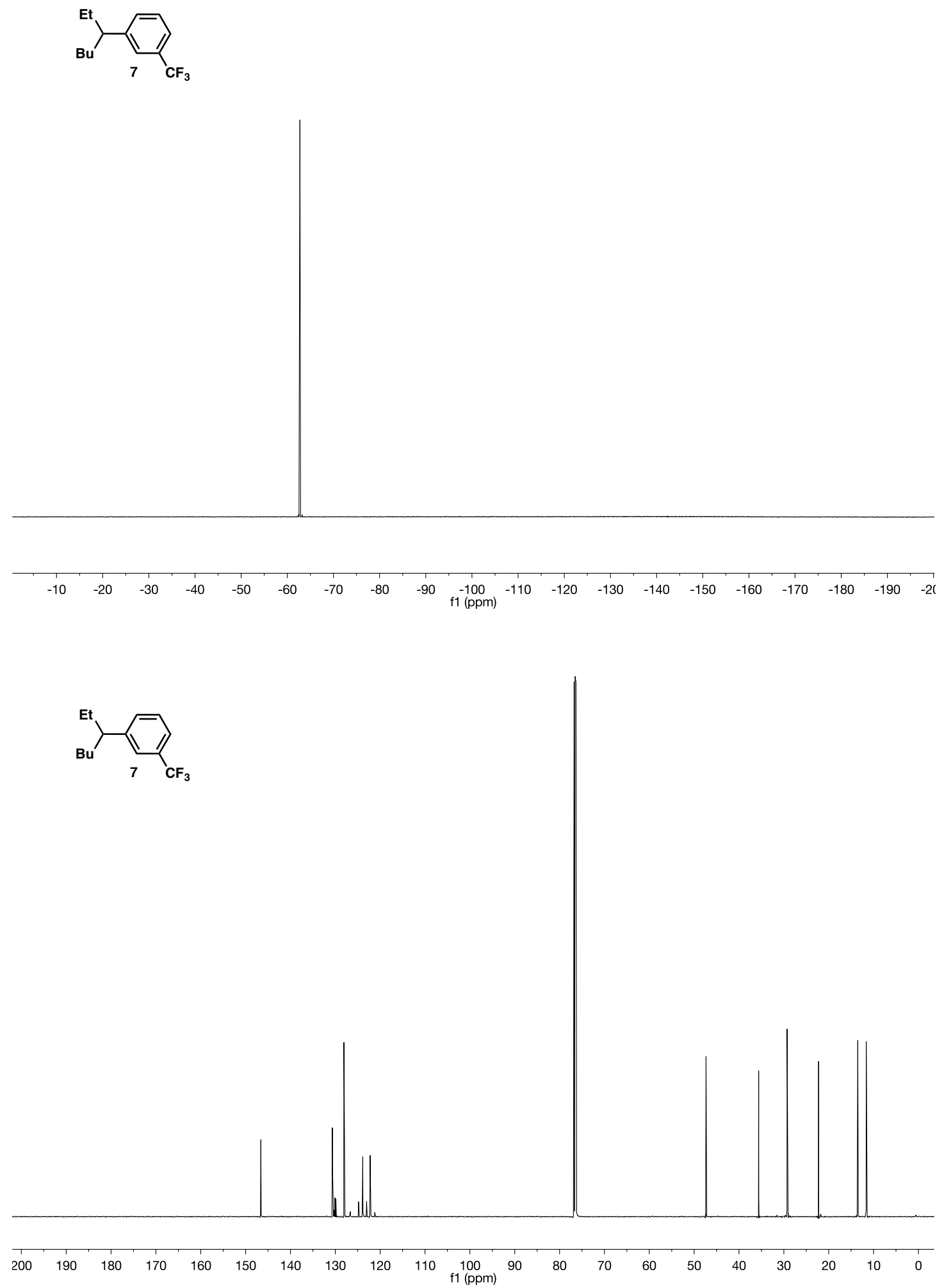

S90 

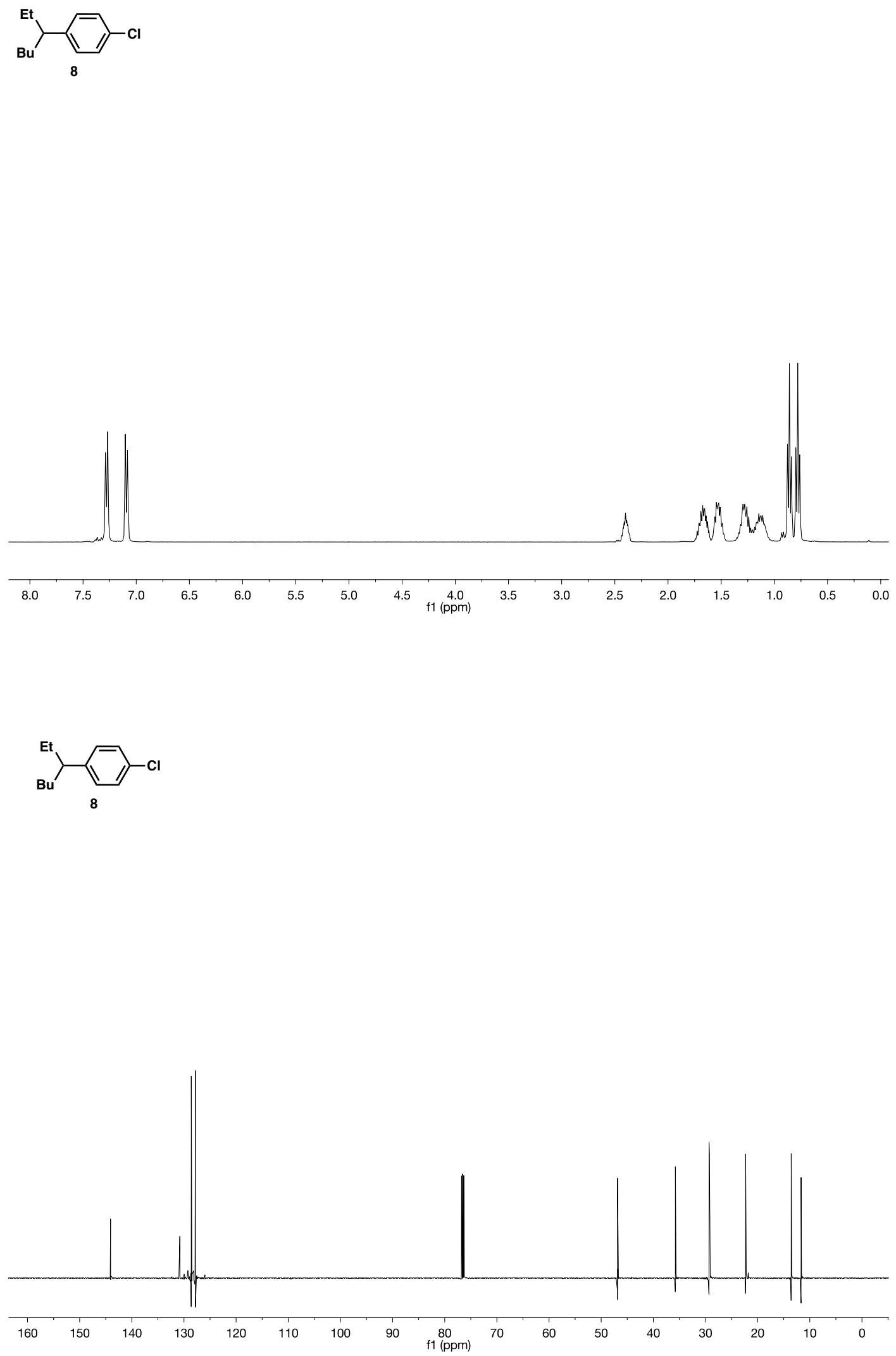

S91 

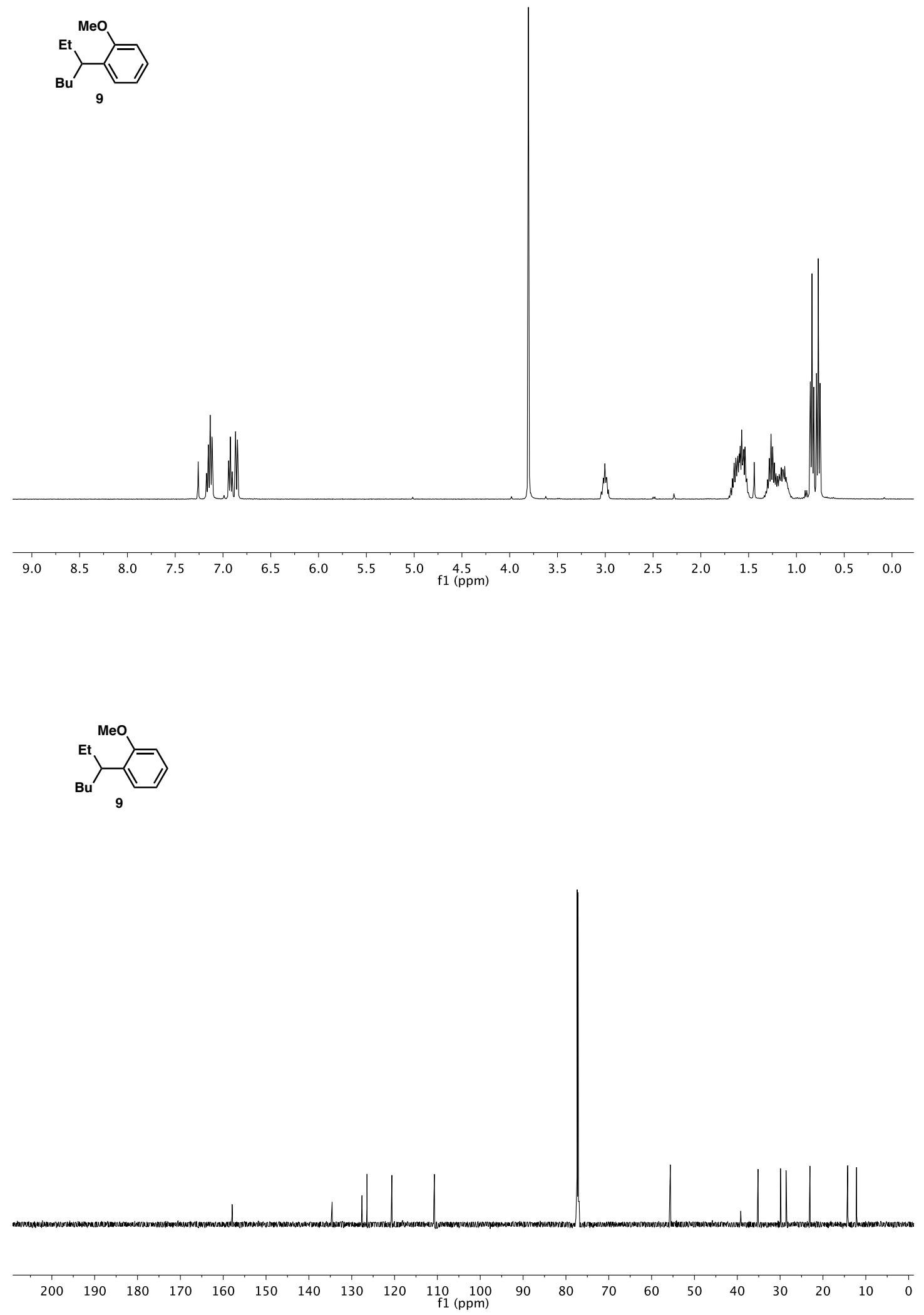

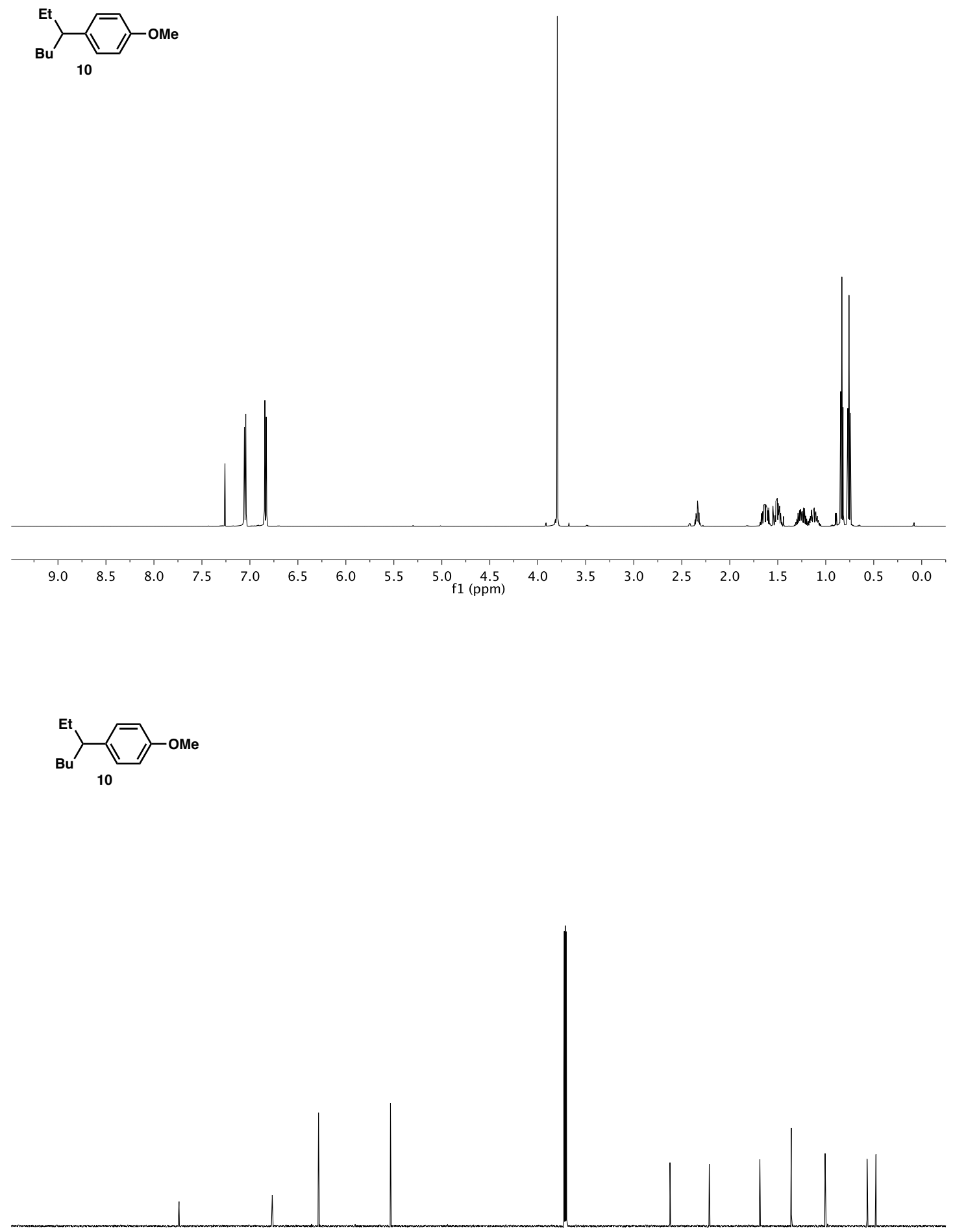

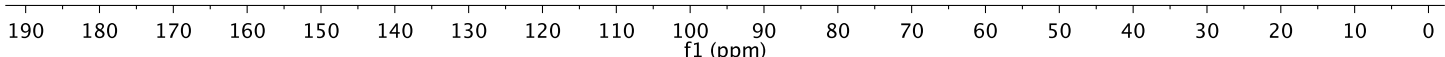



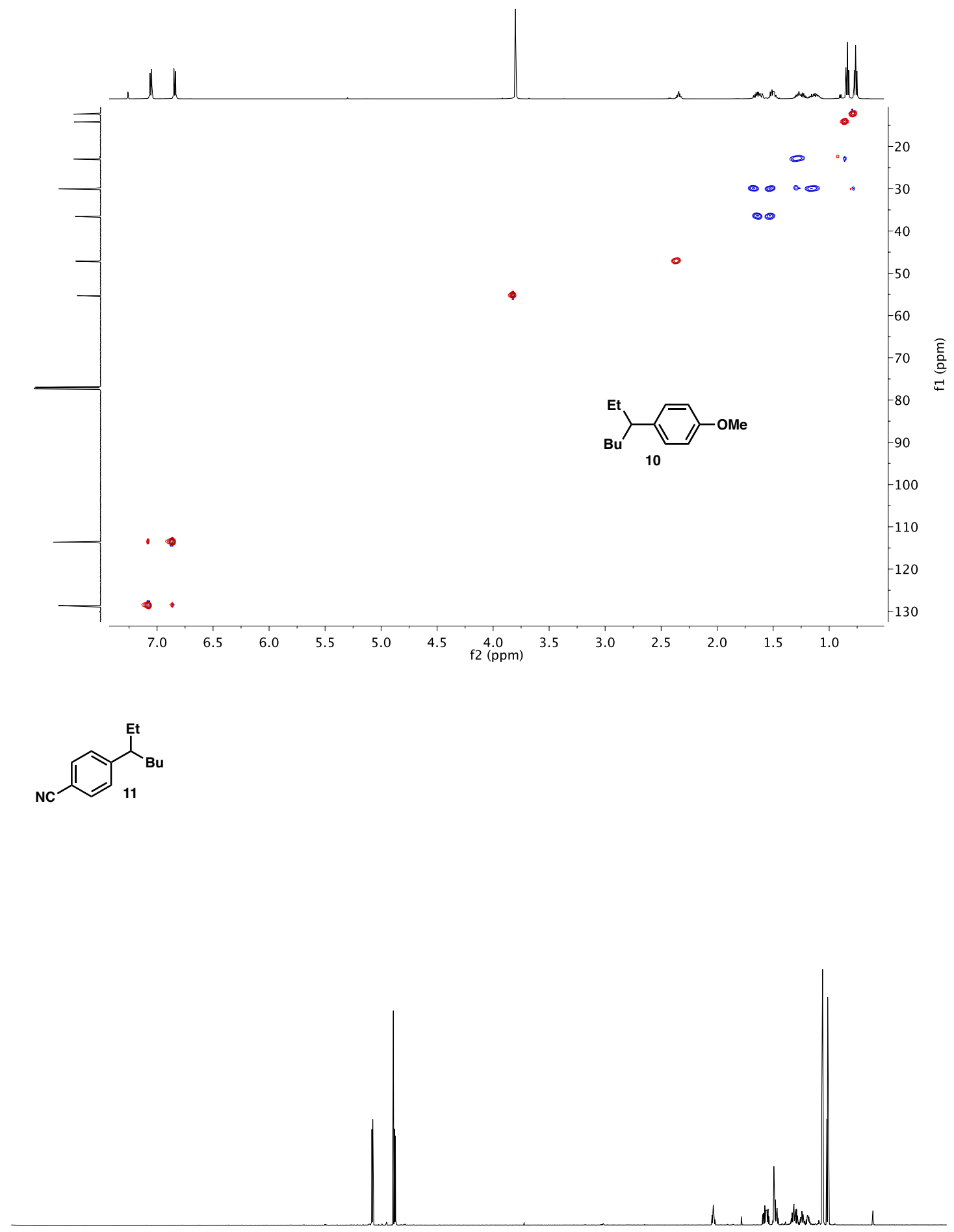

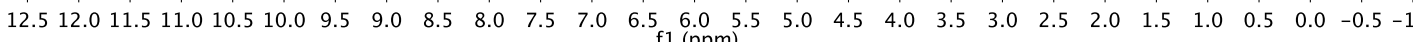




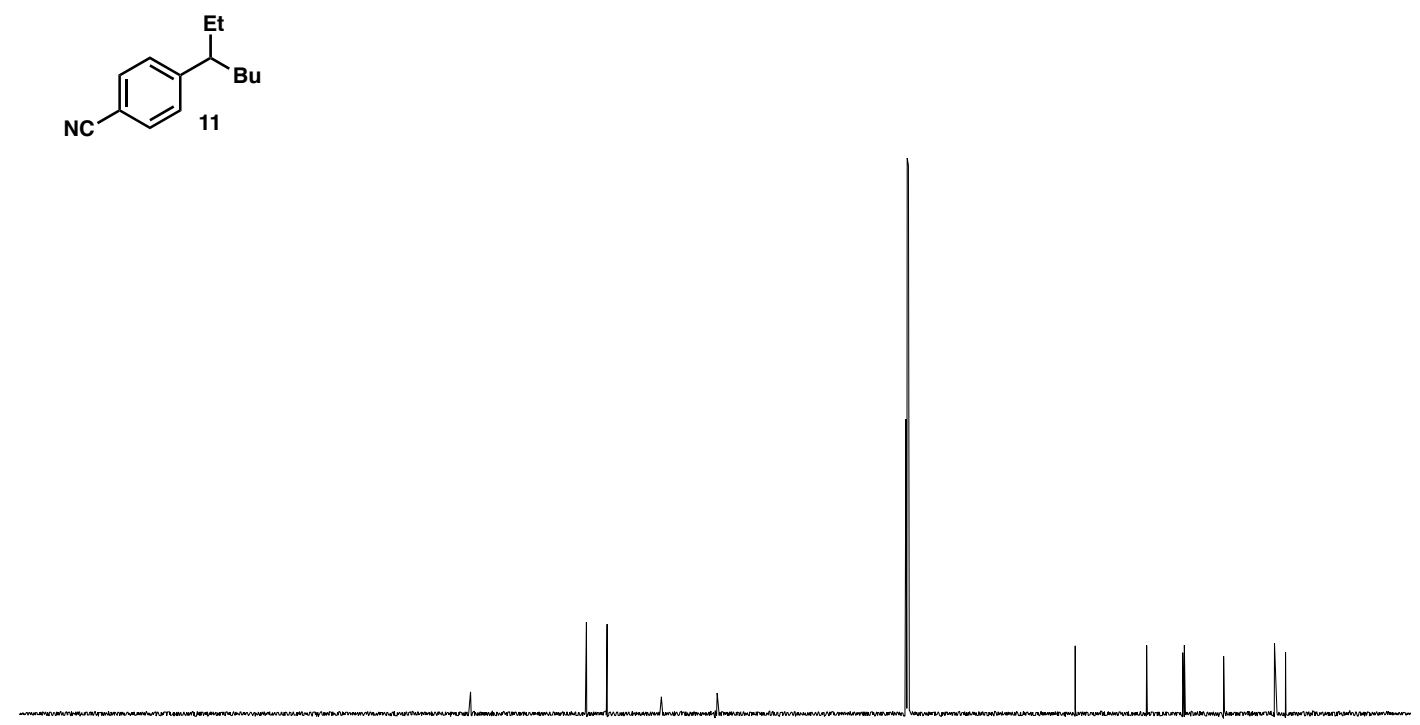

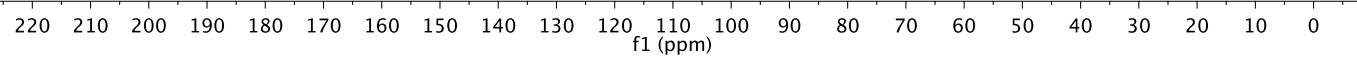<smiles>CCC1C=CC(C)C1</smiles>

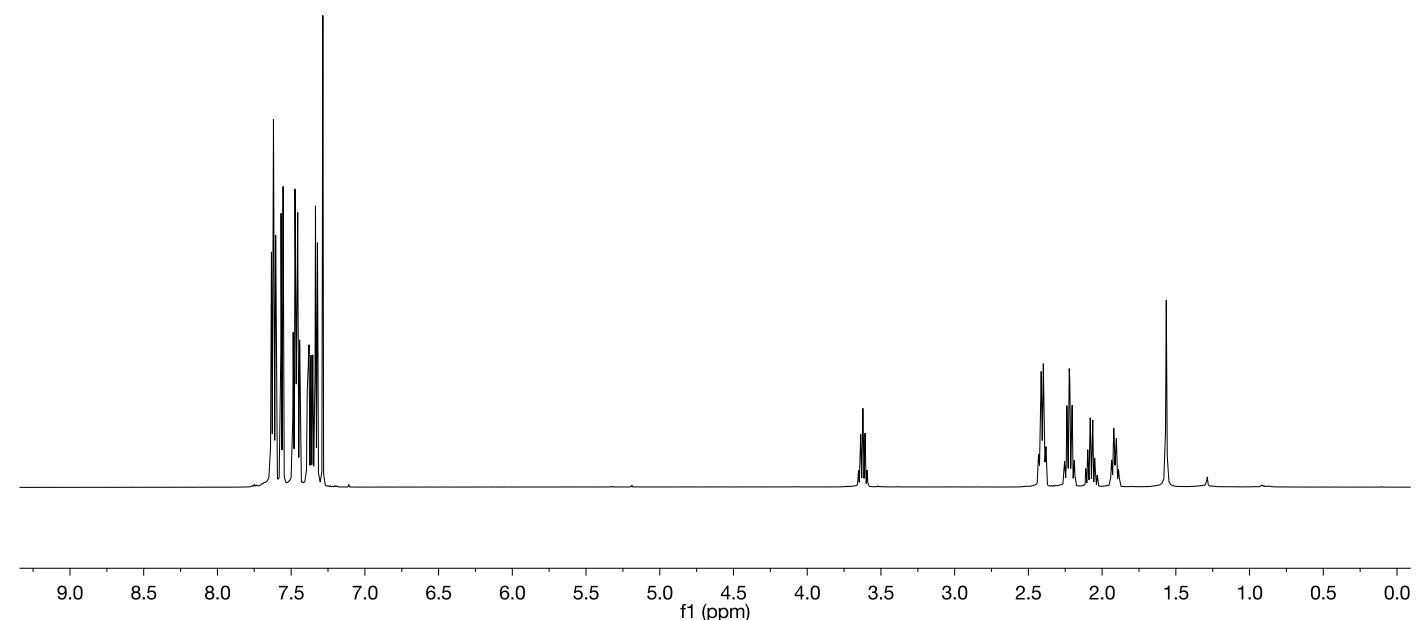




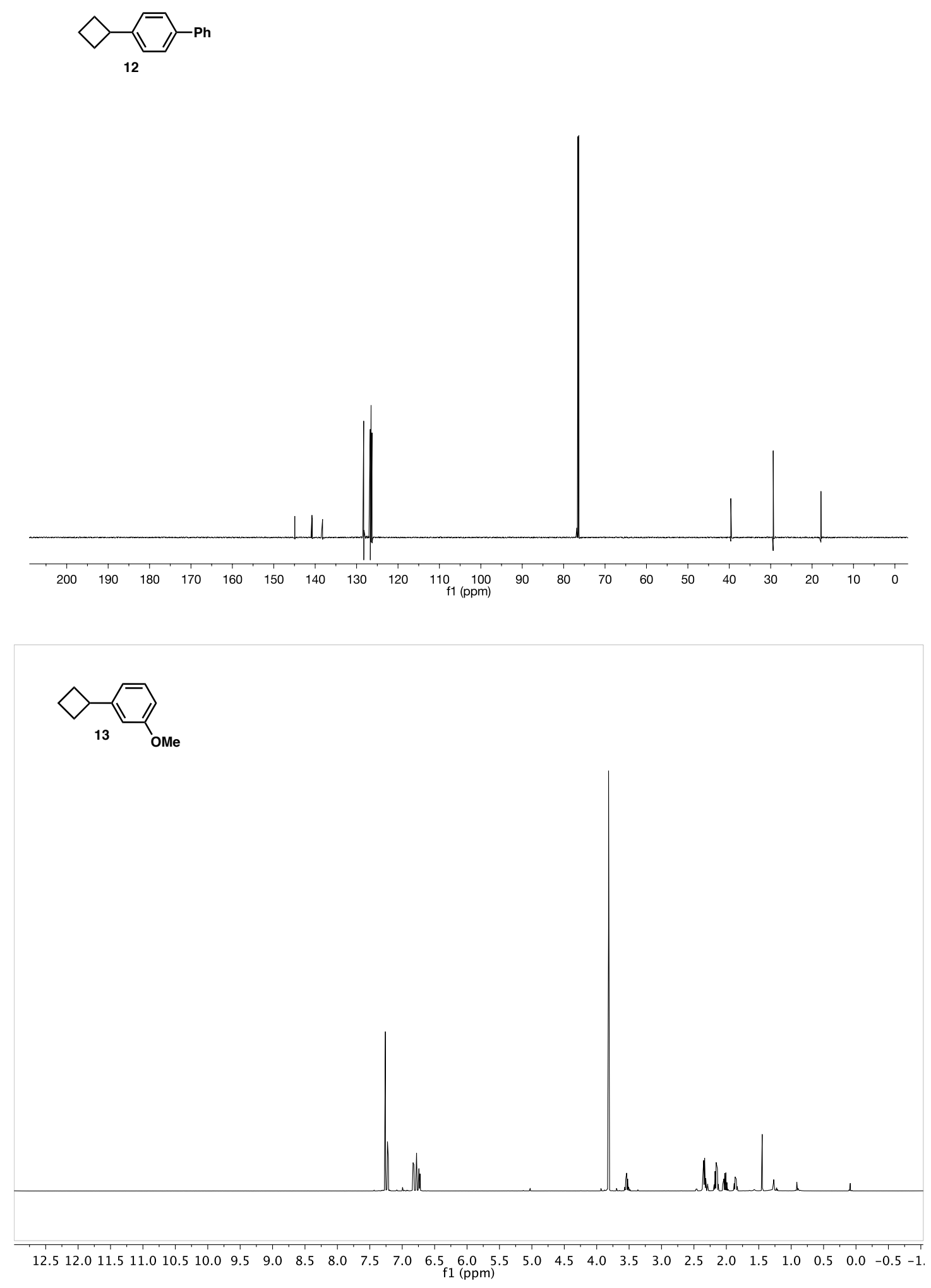




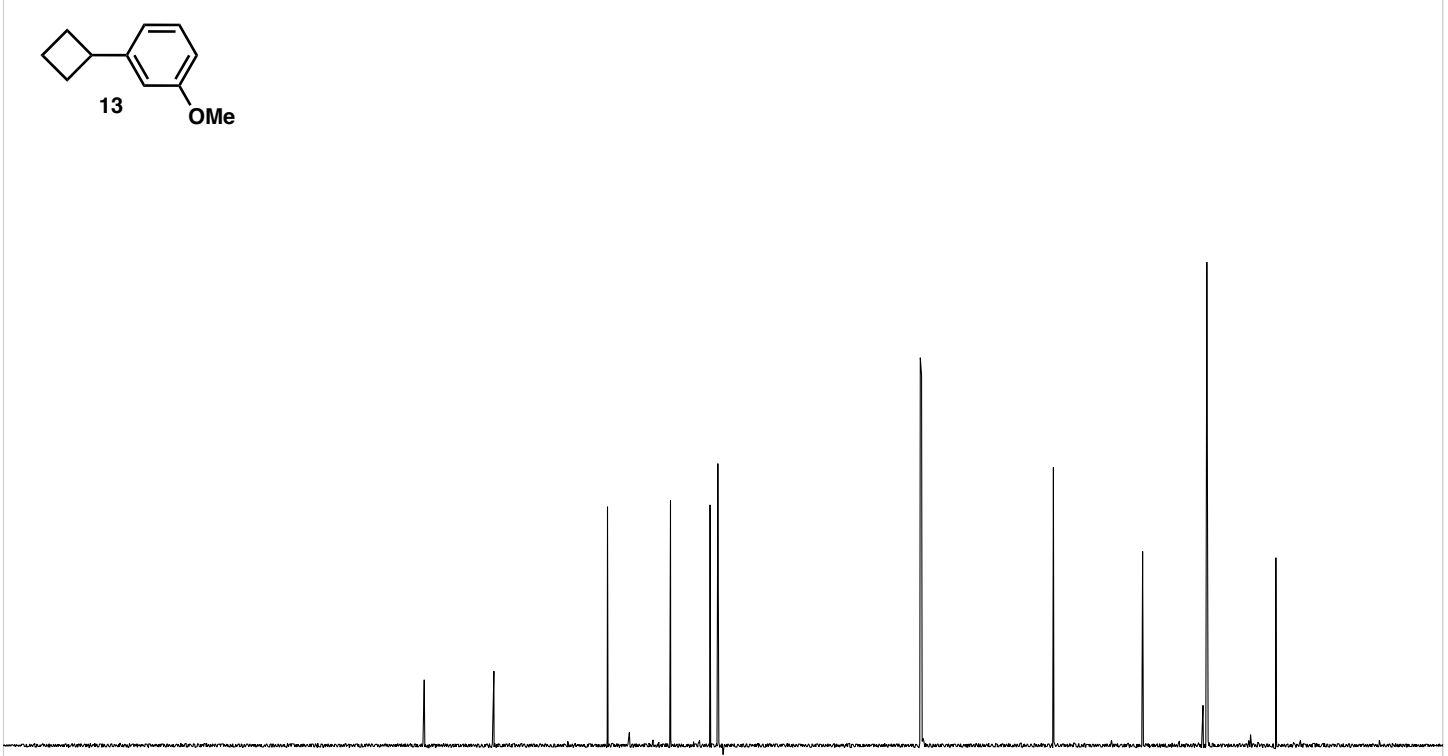

$\begin{array}{lllllllllllllllllllllll}220 & 210 & 200 & 190 & 180 & 170 & 160 & 150 & 140 & 130 & 120 & 110 & 100 & 90 & 80 & 70 & 60 & 50 & 40 & 30 & 20 & 10 & 0\end{array}$
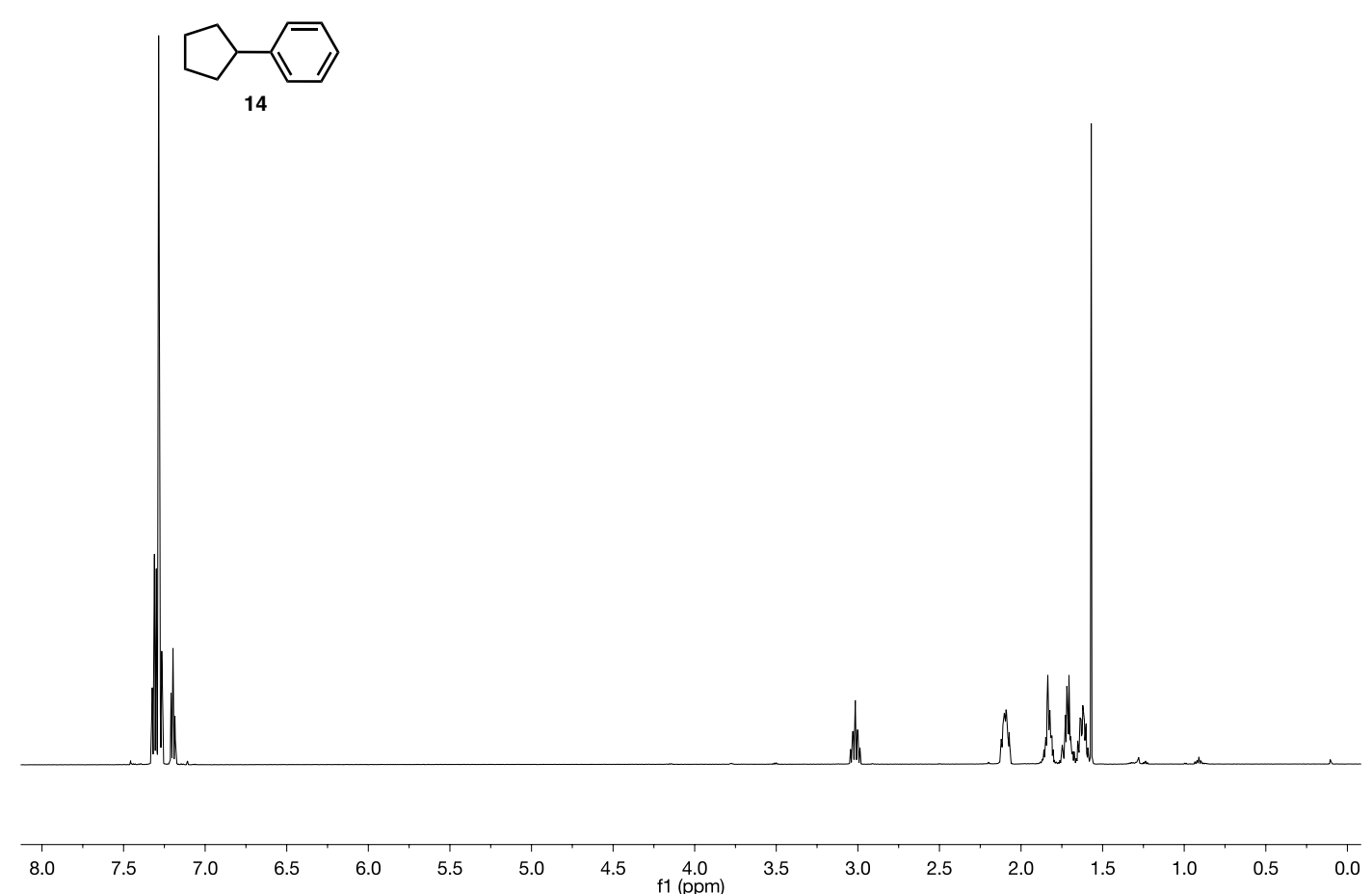
$\square$

14
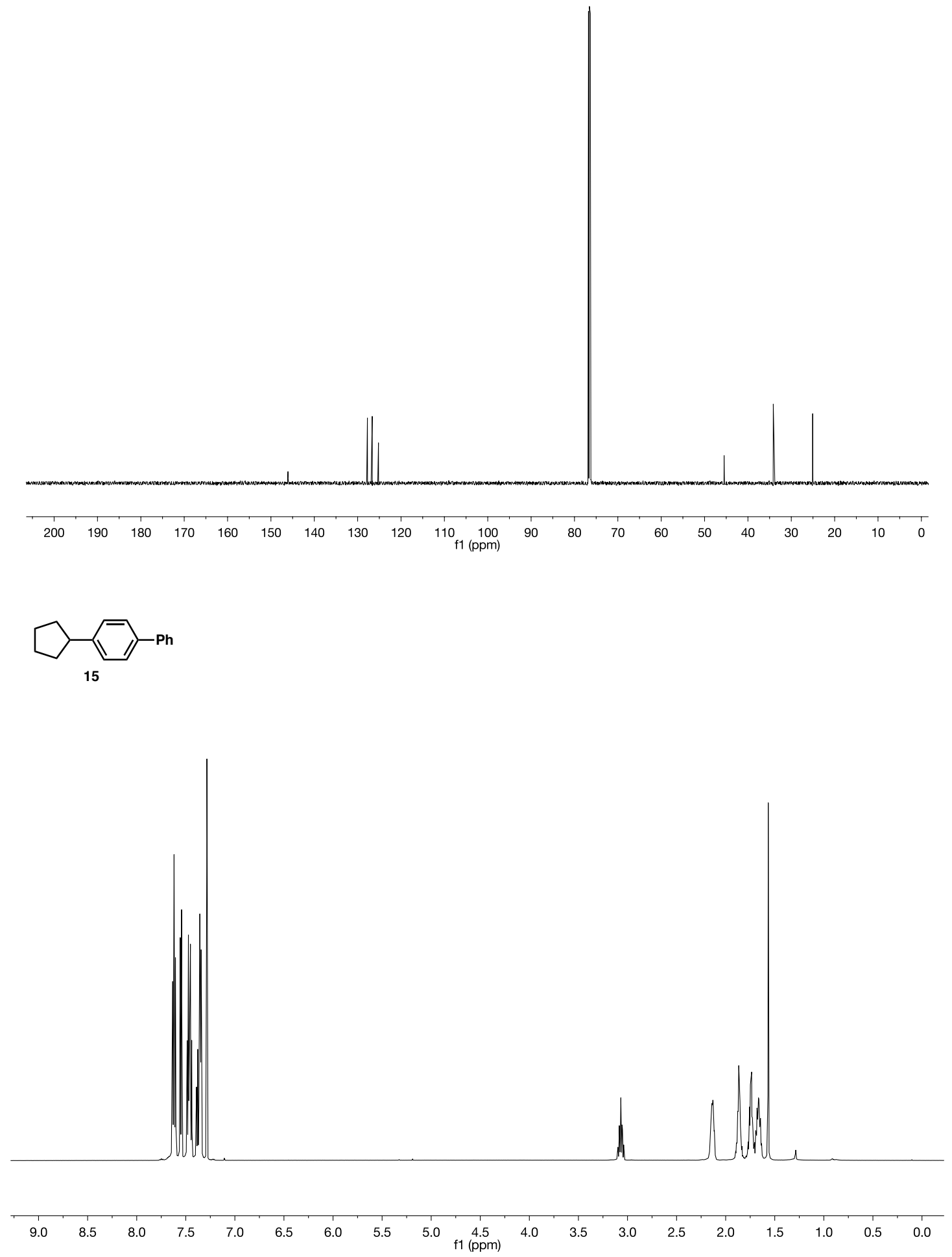


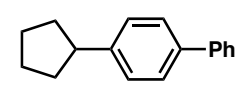

15
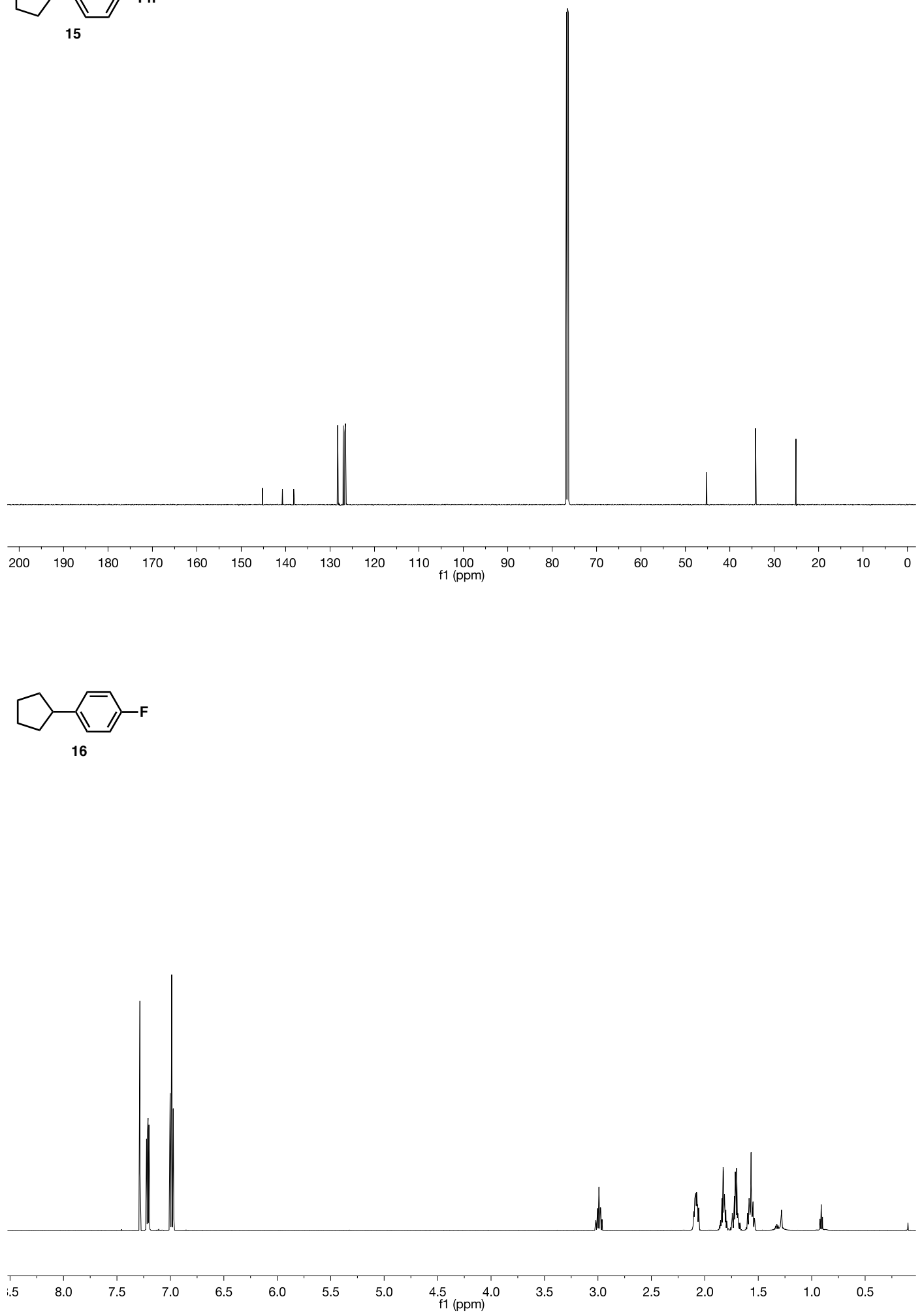

S99 

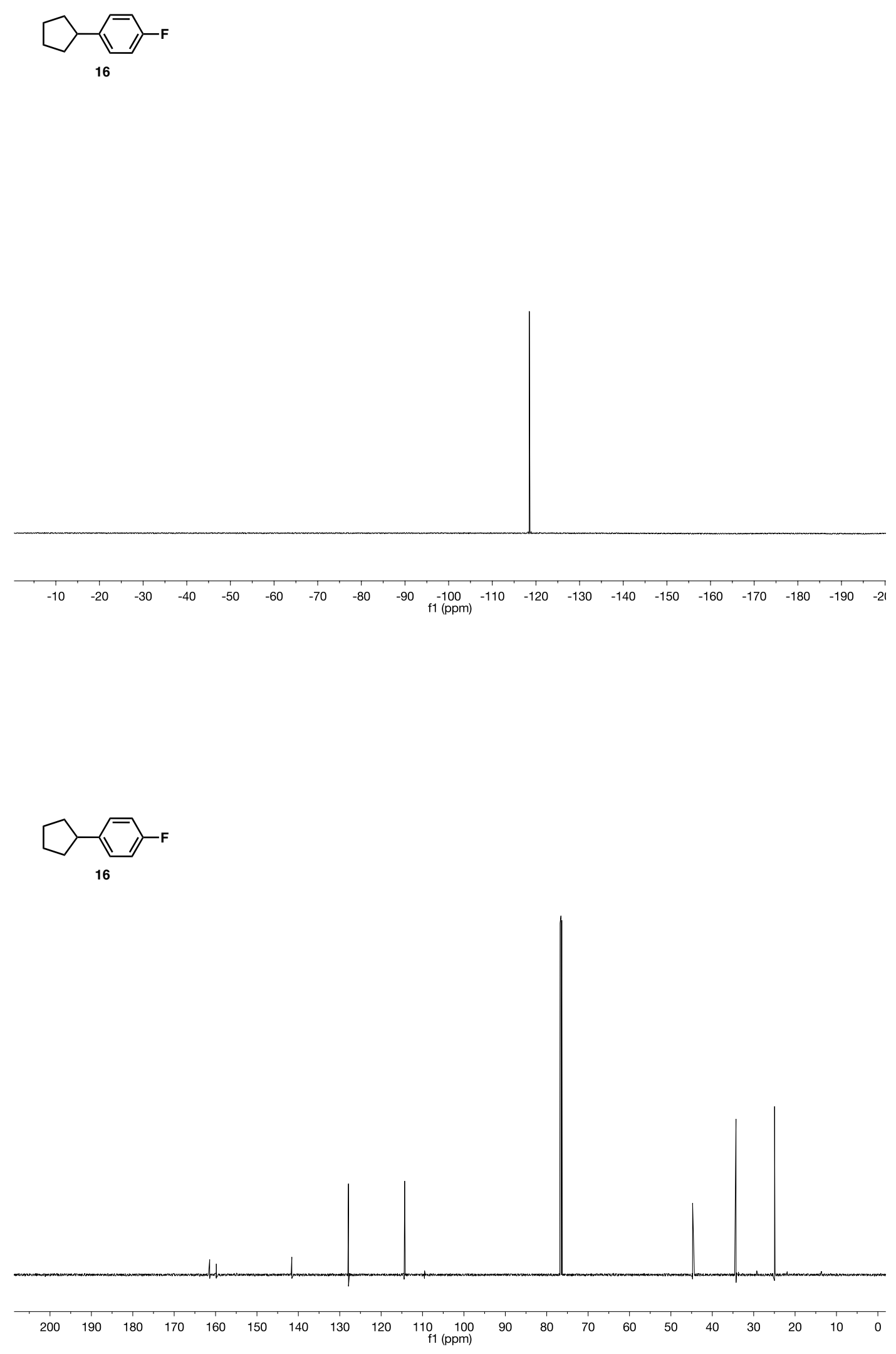

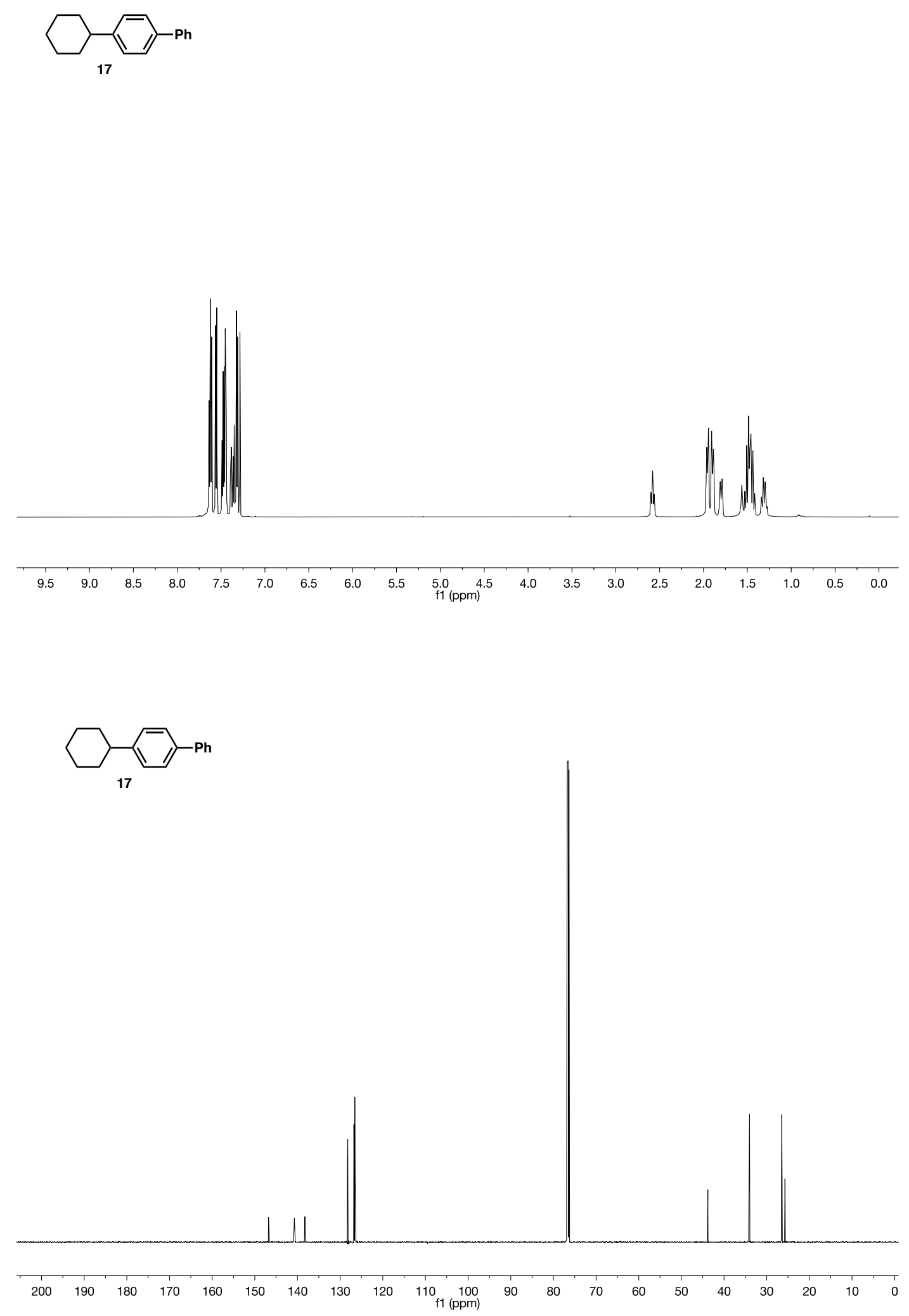

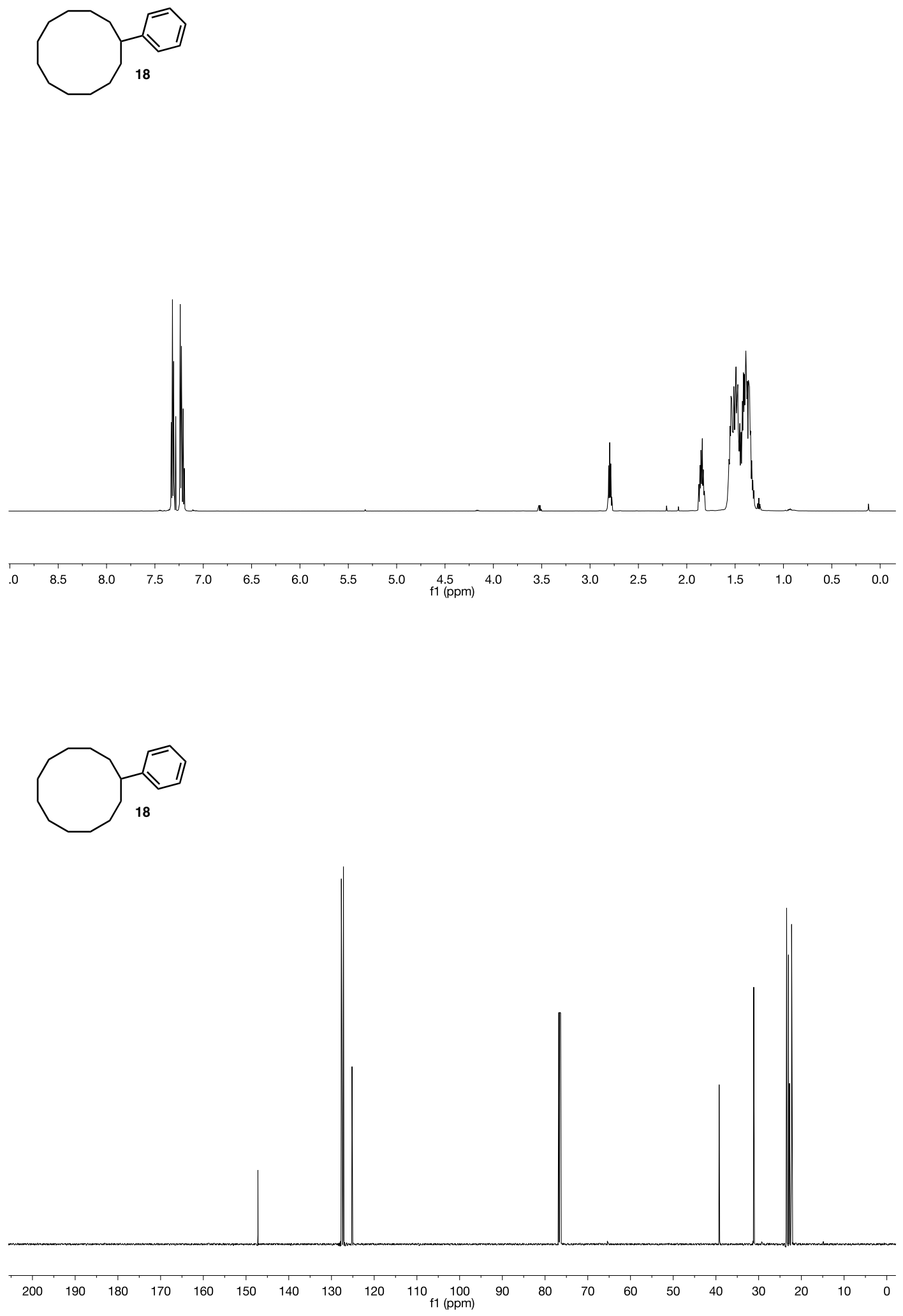

S102 


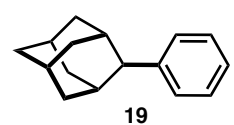

19
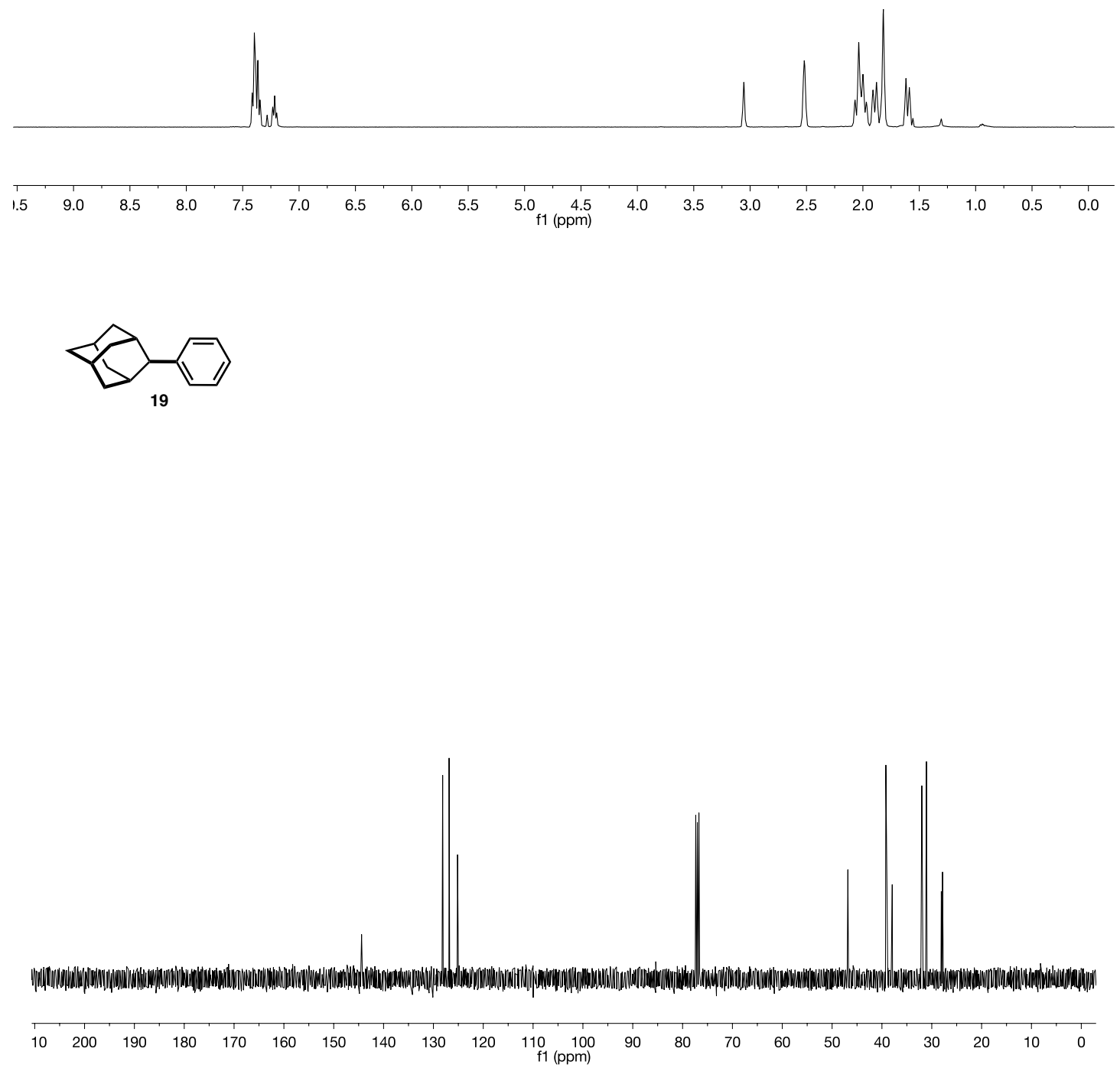

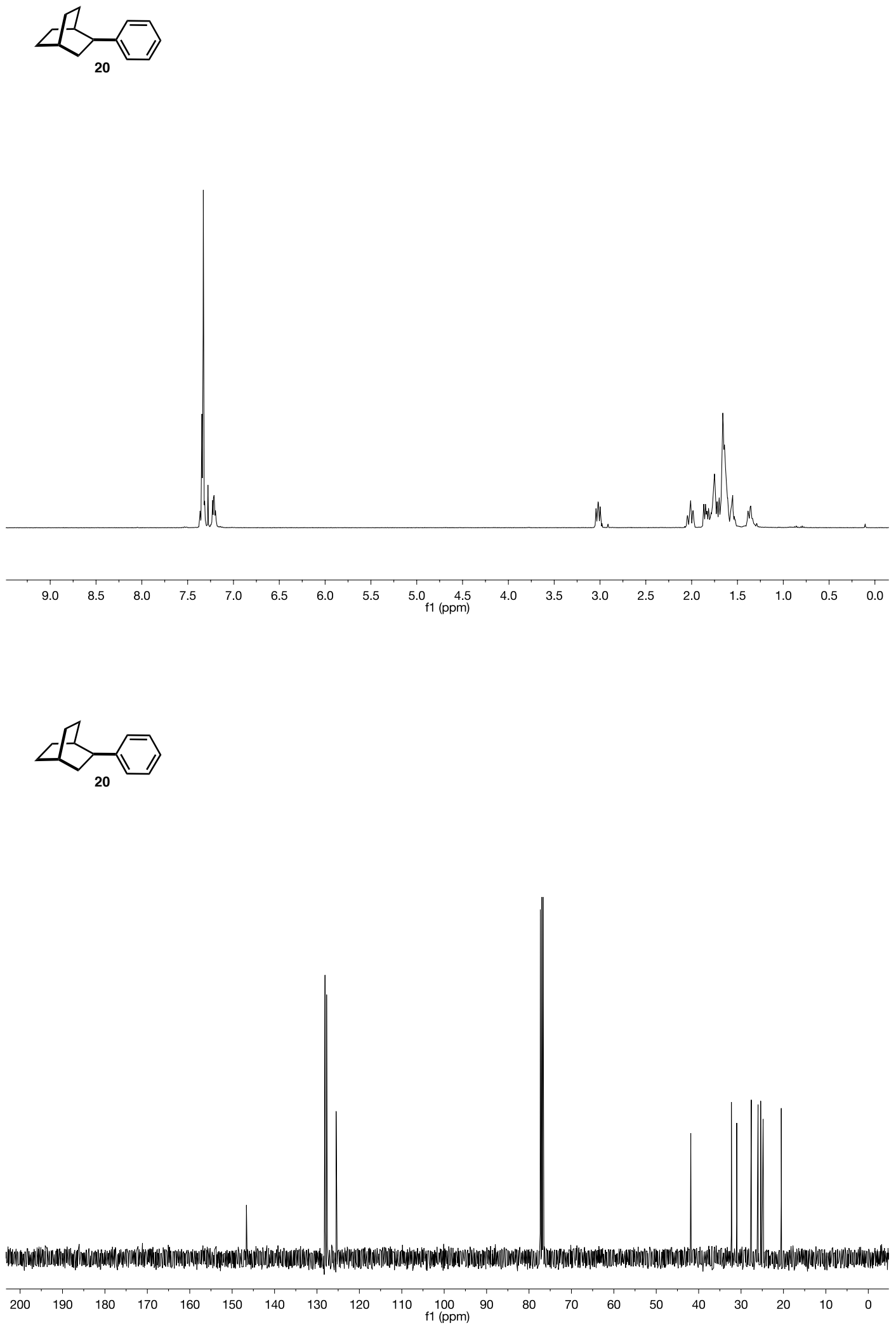

S104 

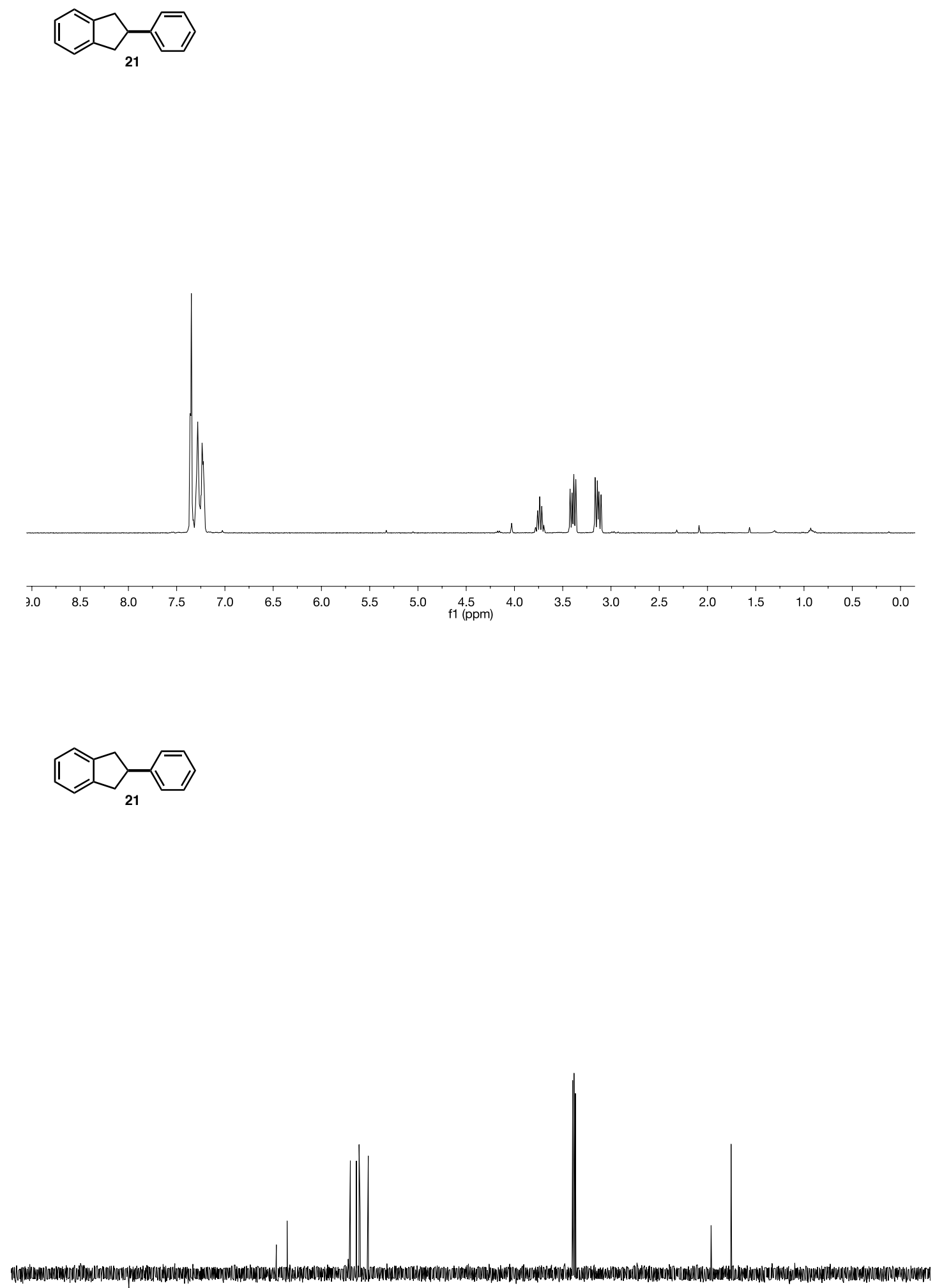

200 190 180

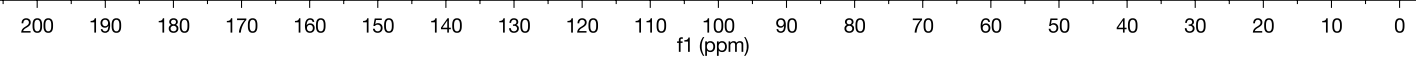



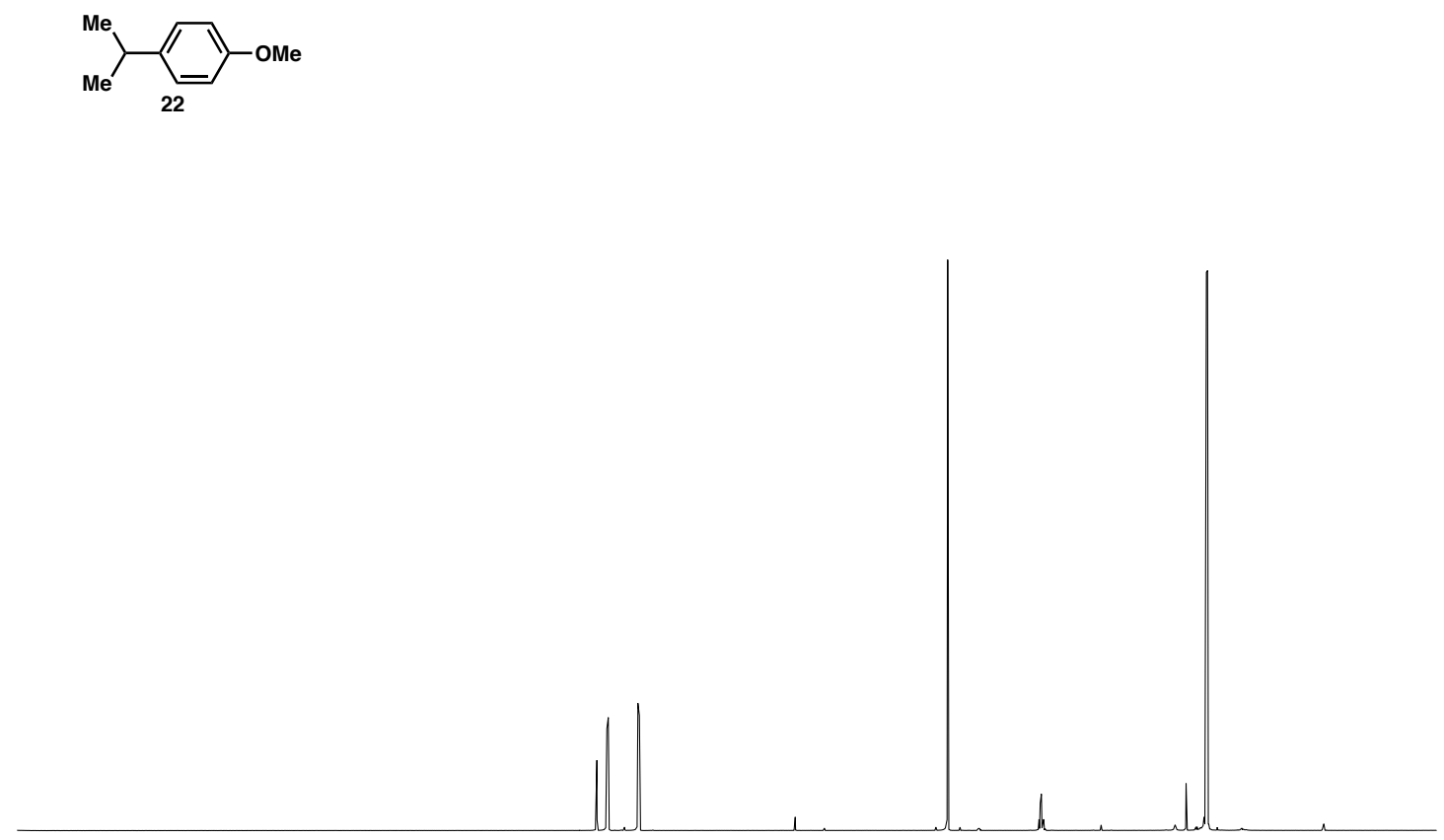

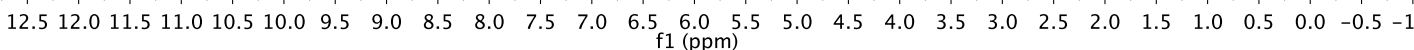<smiles>COc1ccc(C(C)C)cc1</smiles>

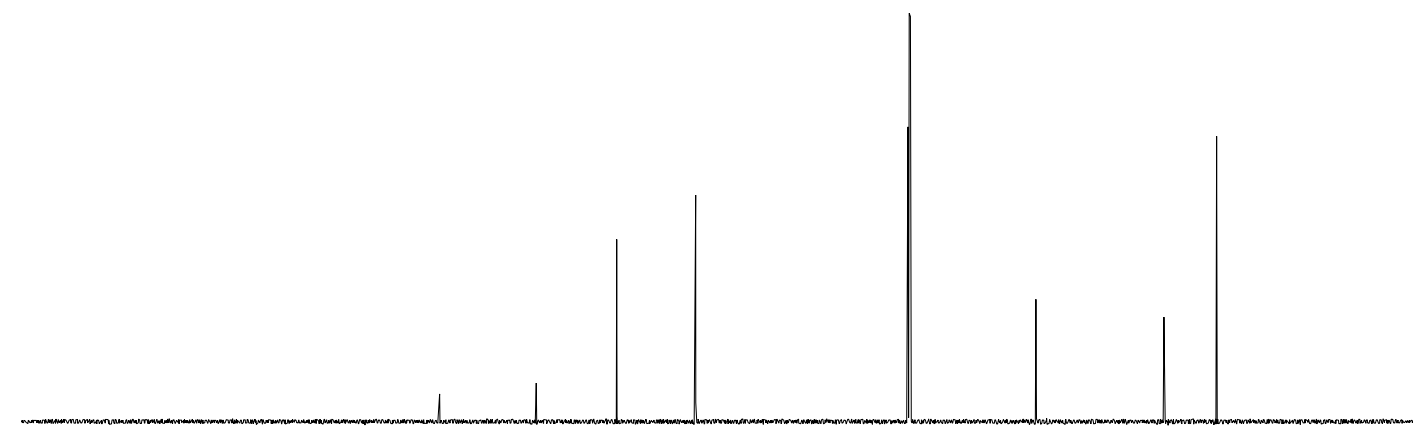

$\begin{array}{lllllllllllllllllllllll}220 & 210 & 200 & 190 & 180 & 170 & 160 & 150 & 140 & 130 & 120 & \underset{f 1}{110}(\mathrm{ppm}) & 100 & 90 & 80 & 70 & 60 & 50 & 40 & 30 & 20 & 10 & 0\end{array}$ 

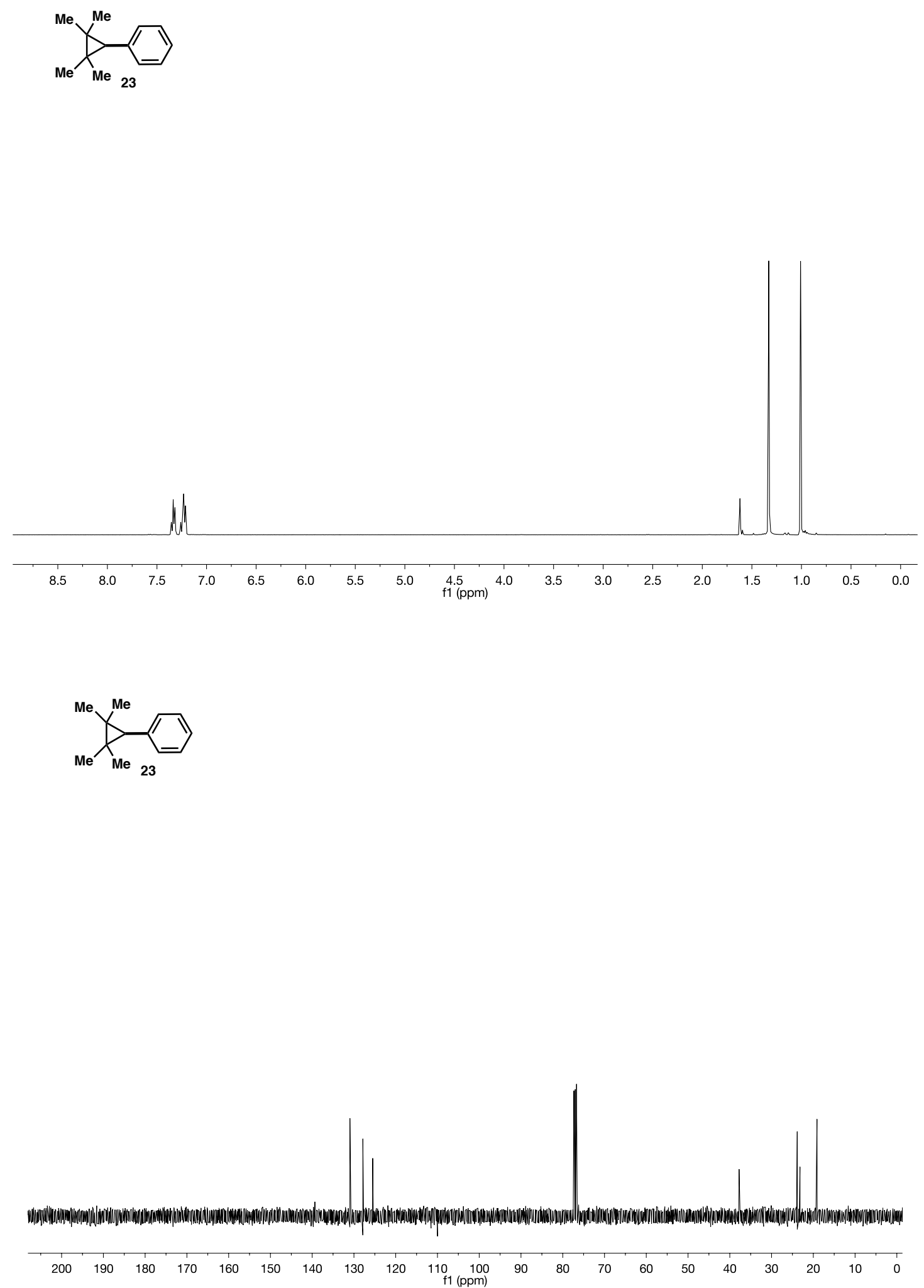

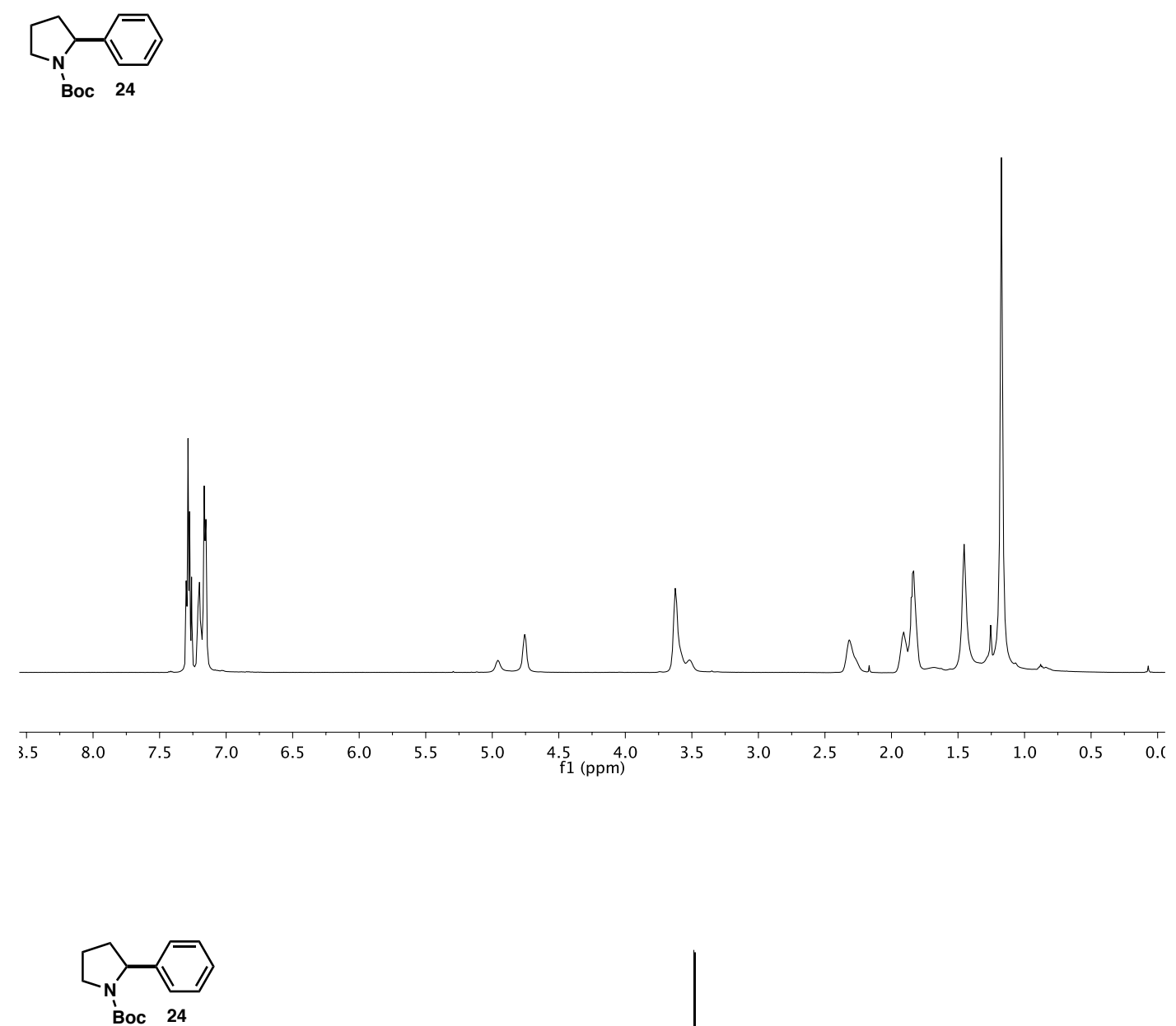

Boc 24 

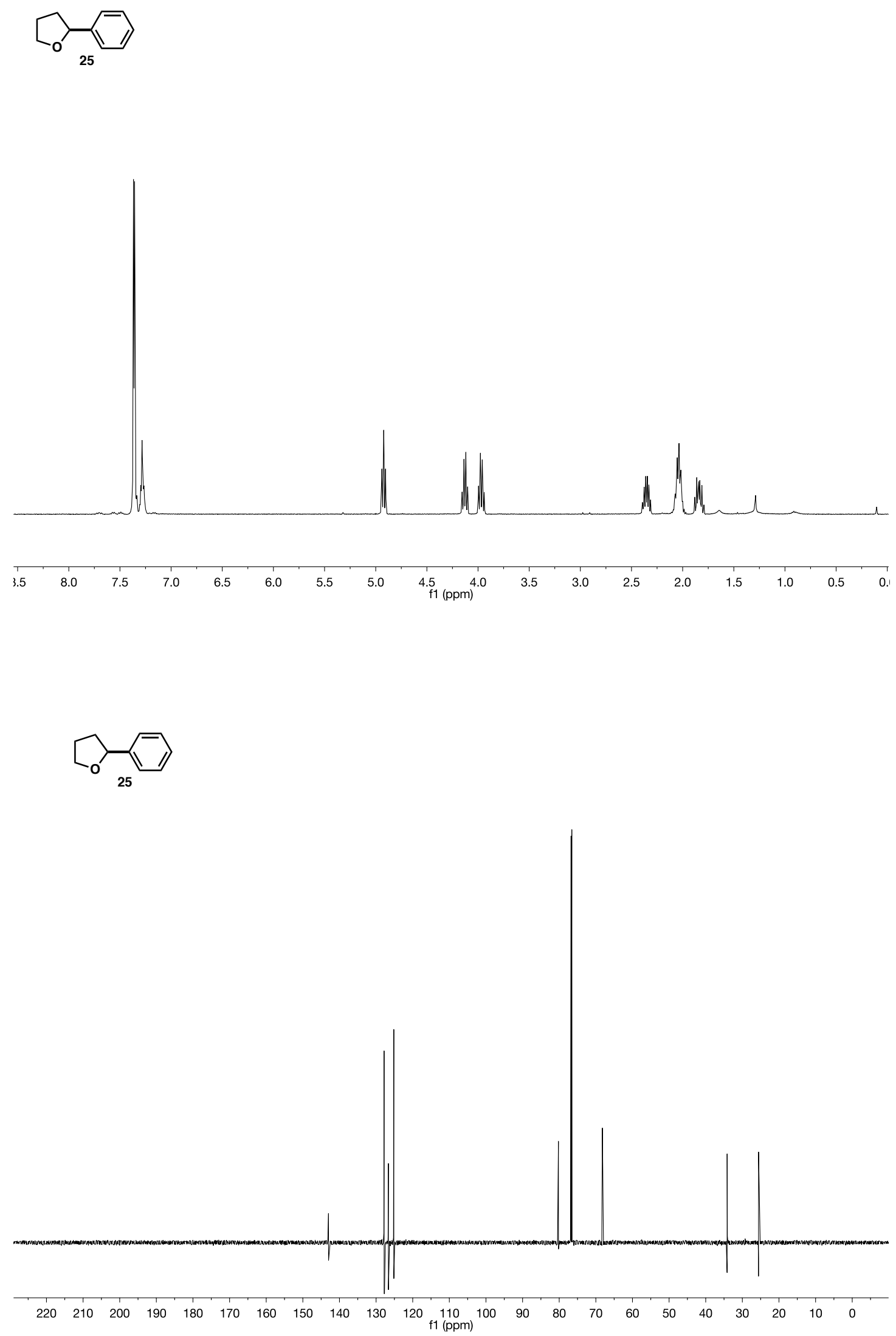

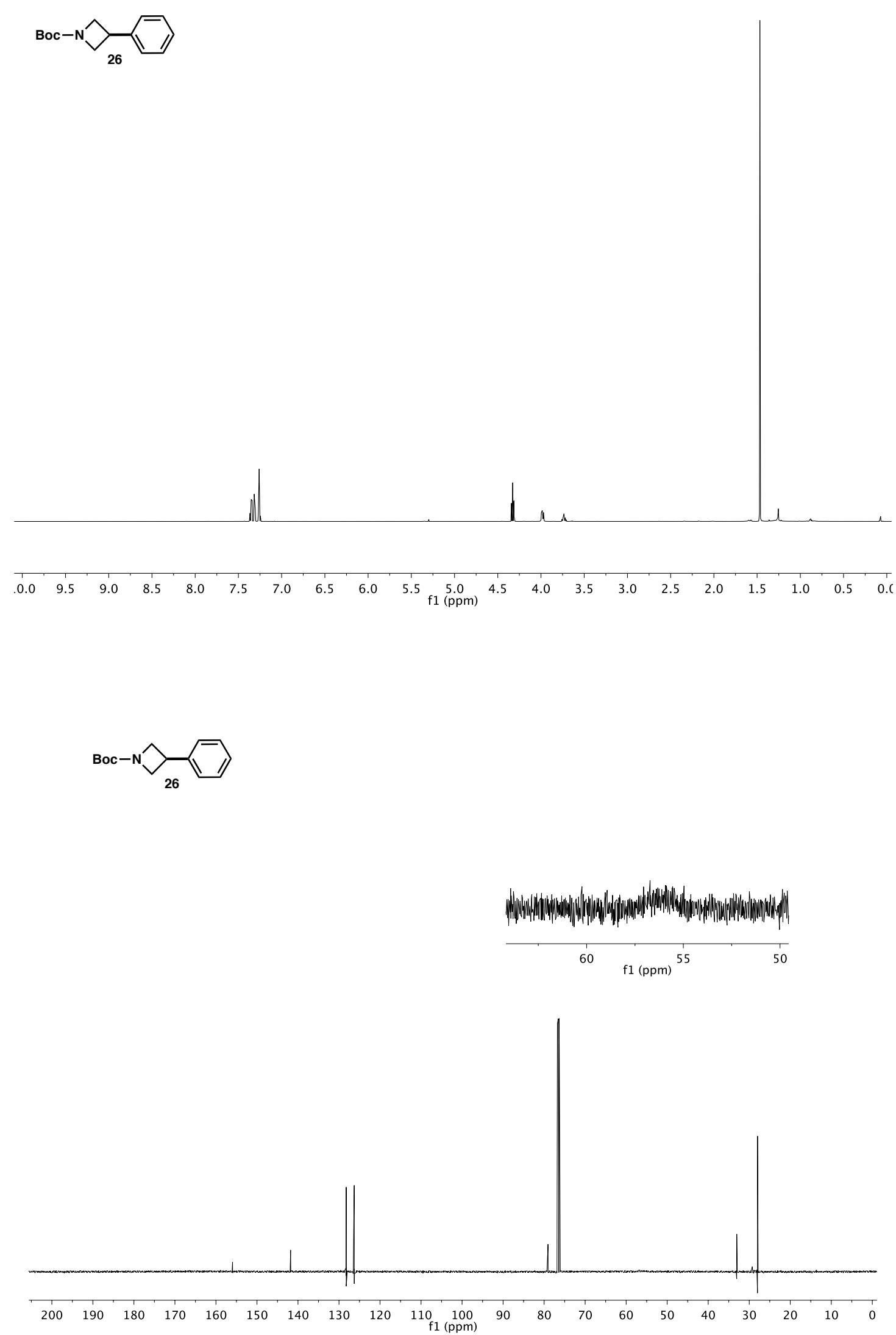


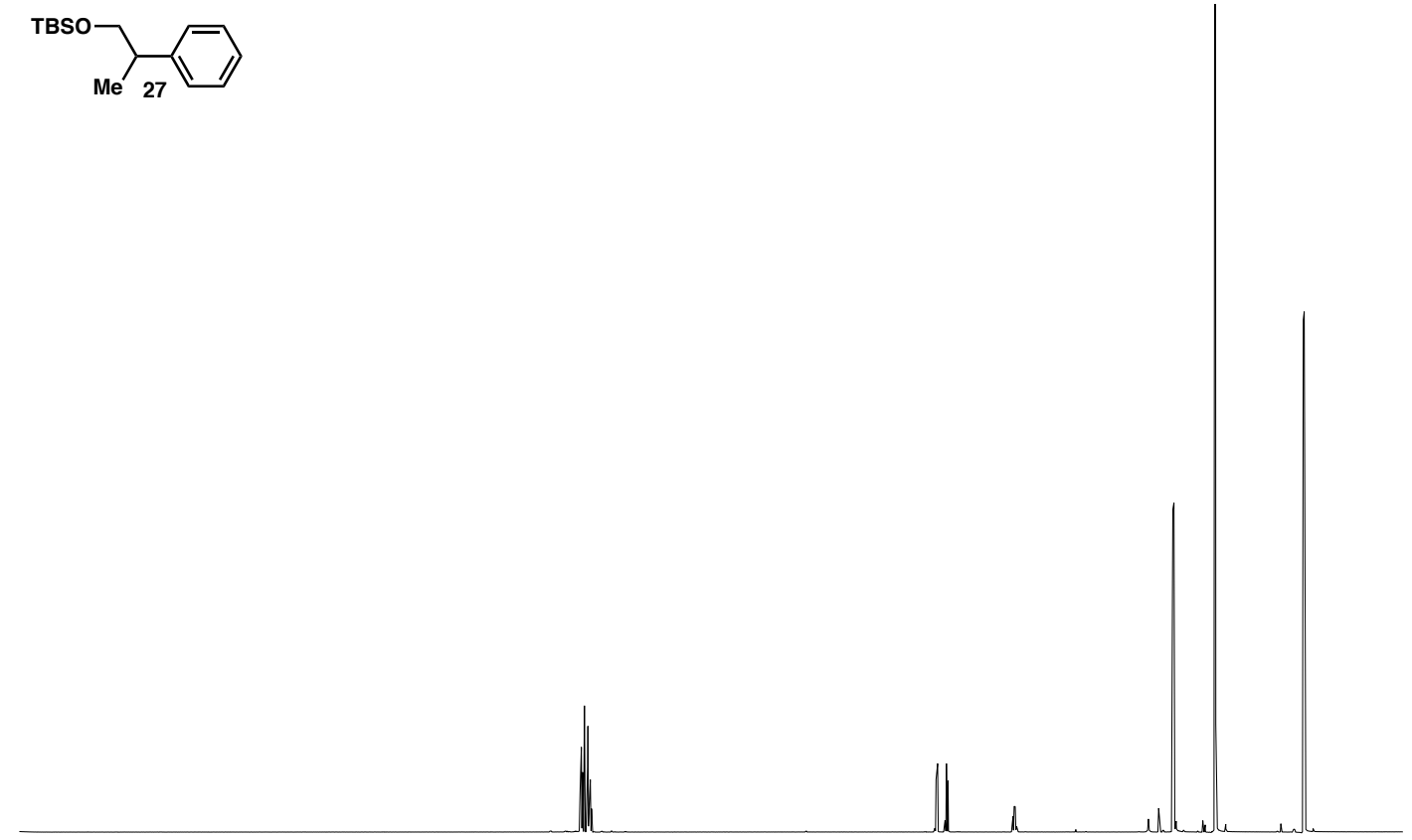

$\begin{array}{llllllllllllllllllllllllllllllllll}12.5 & 12.0 & 11.5 & 11.0 & 10.5 & 10.0 & 9.5 & 9.0 & 8.5 & 8.0 & 7.5 & 7.0 & 6.5 & 6.0 & 5.5 & 5.0 & 4.5 & 4.0 & 3.5 & 3.0 & 2.5 & 2.0 & 1.5 & 1.0 & 0.5 & 0.0 & -0.5 & -1\end{array}$
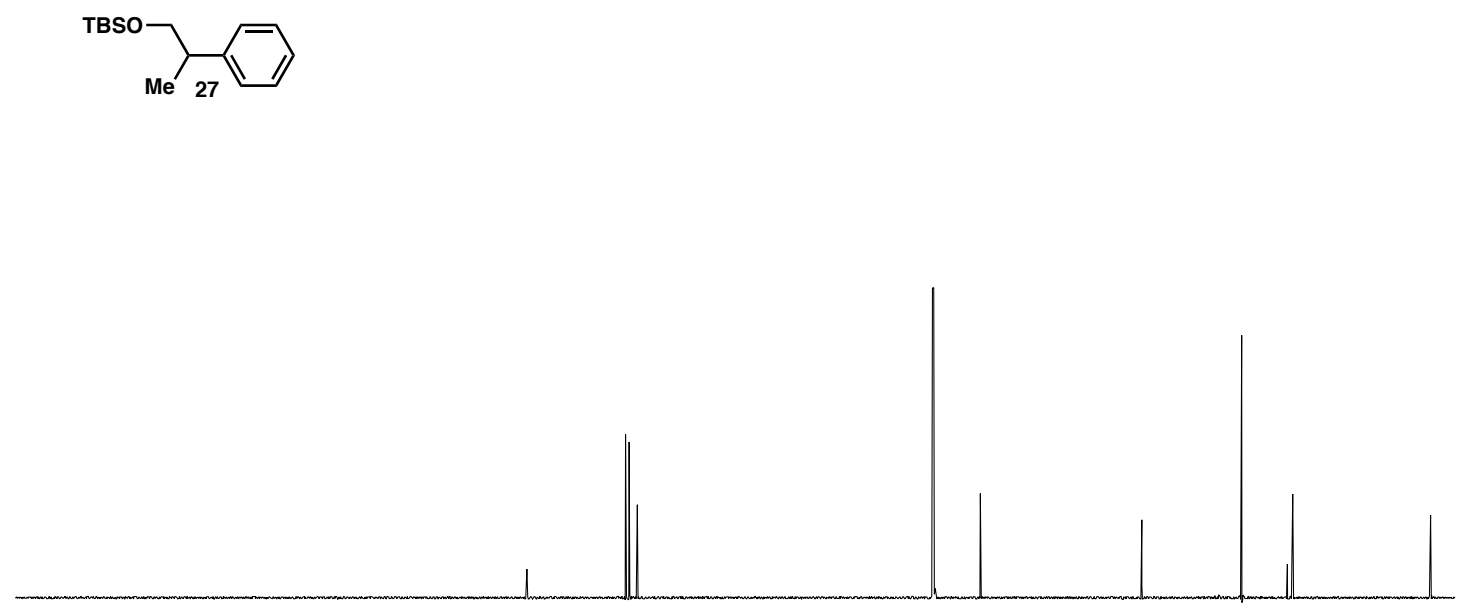

$\begin{array}{lllllllllllllllllllllll}220 & 210 & 200 & 190 & 180 & 170 & 160 & 150 & 140 & 130 & 120 & 110 & 100 & 90 & 80 & 70 & 60 & 50 & 40 & 30 & 20 & 10 & 0\end{array}$ 

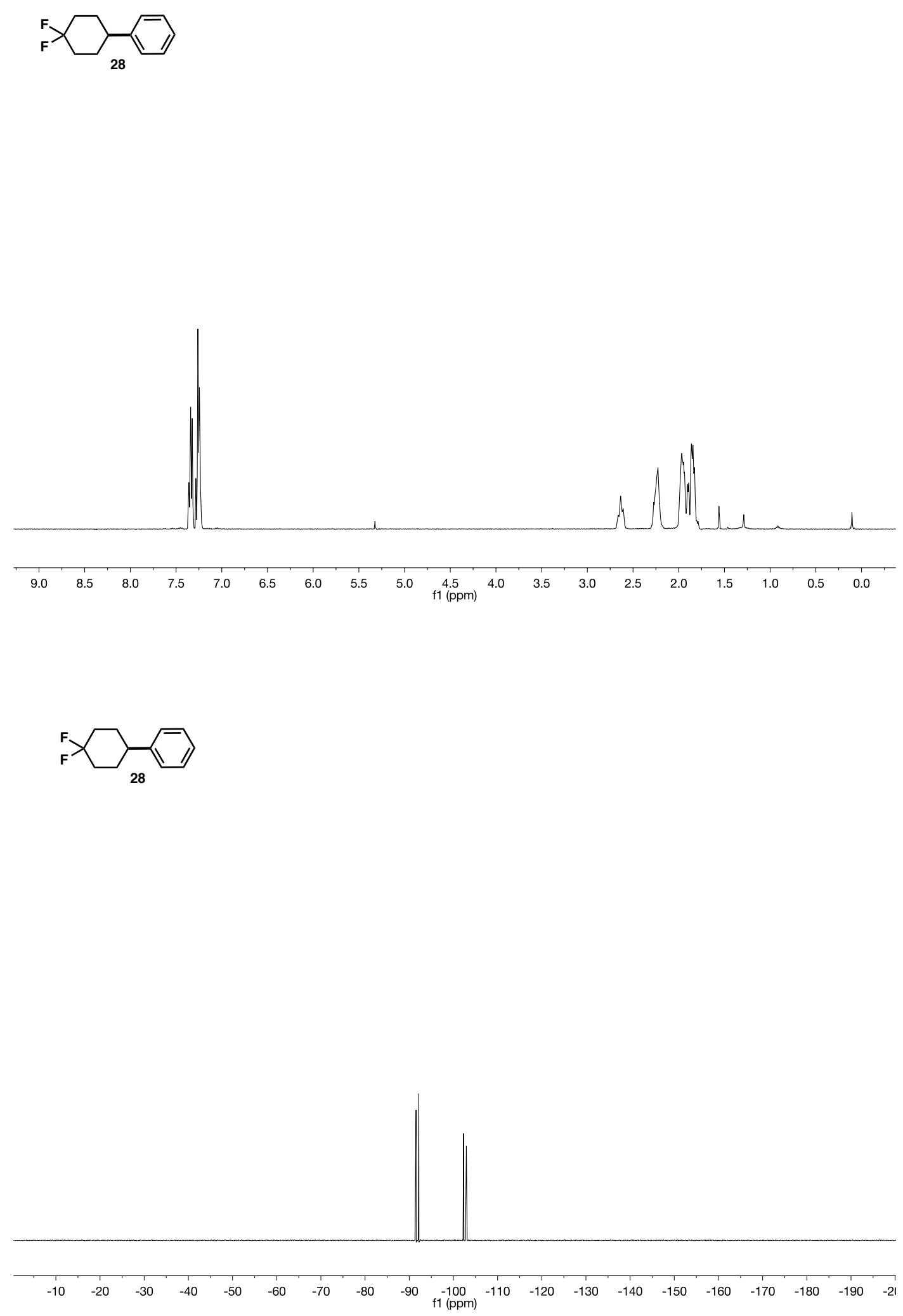

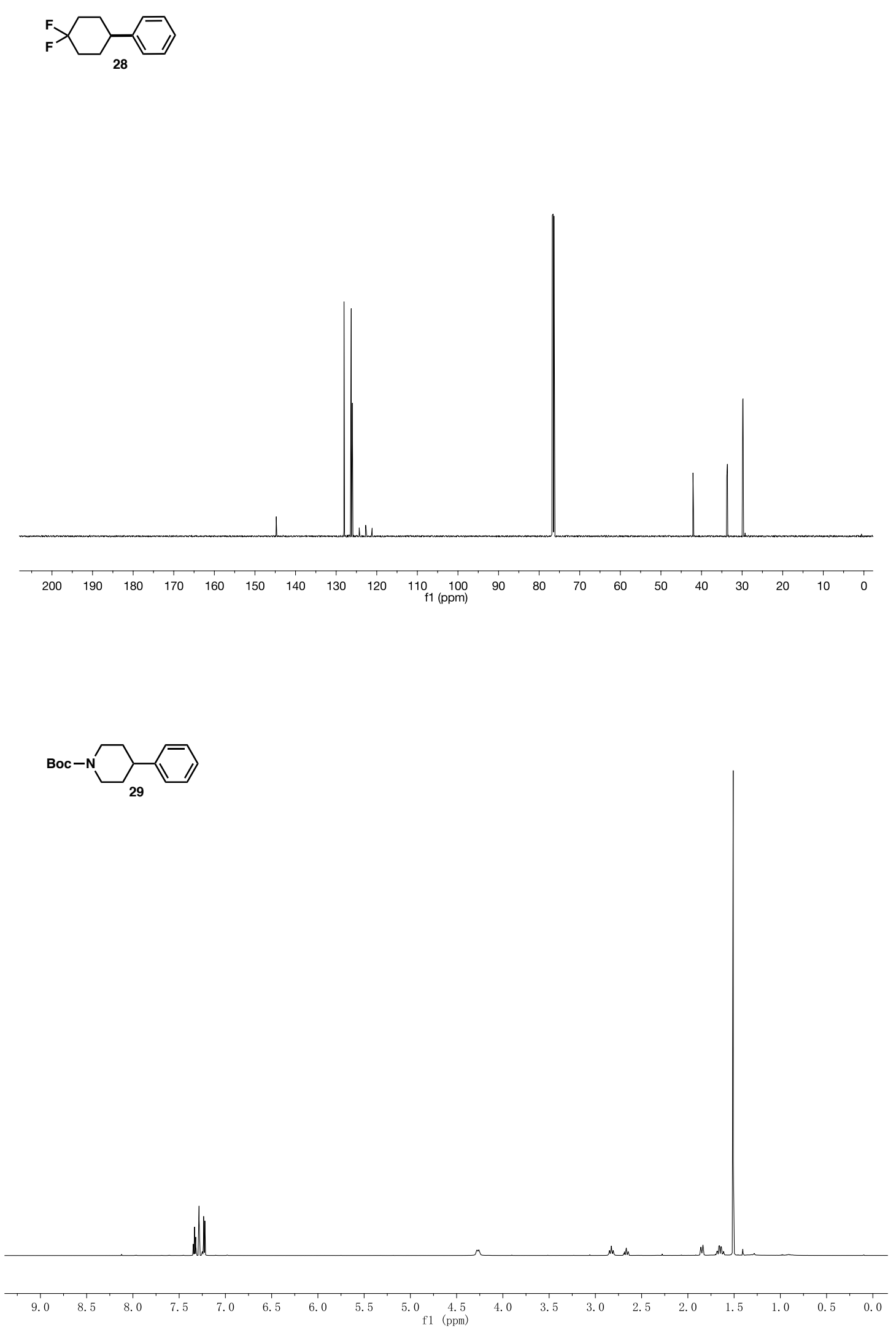

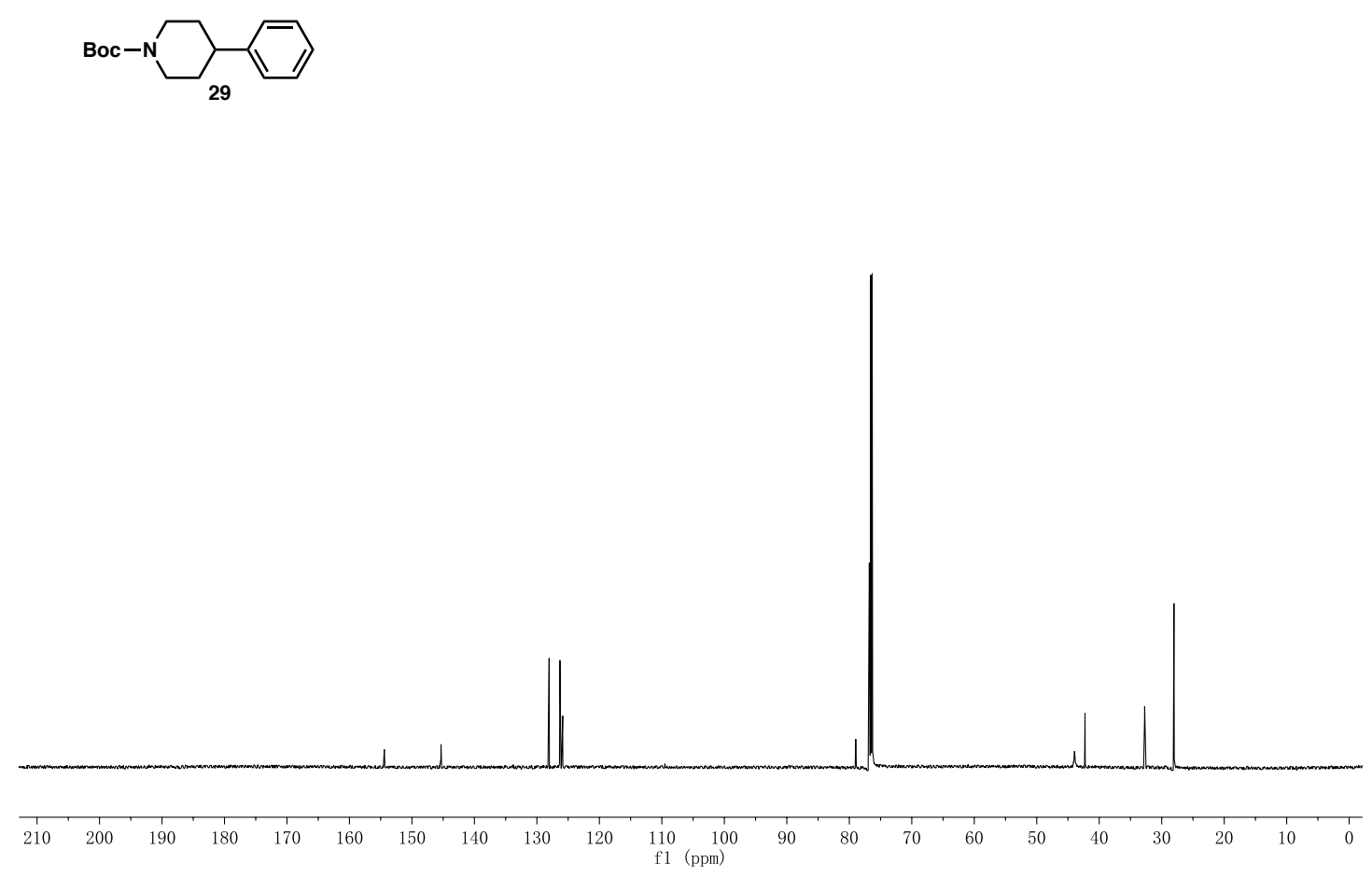

깅

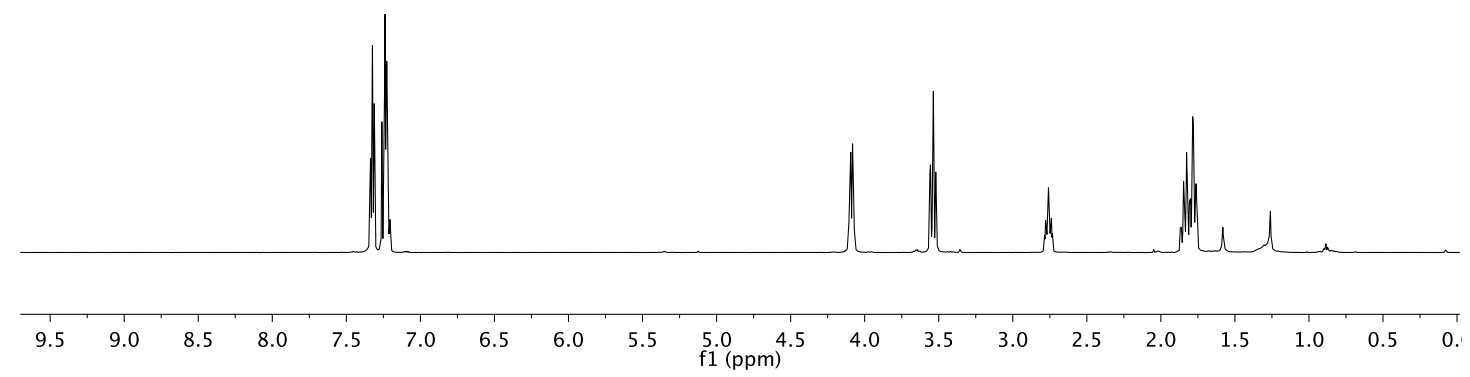




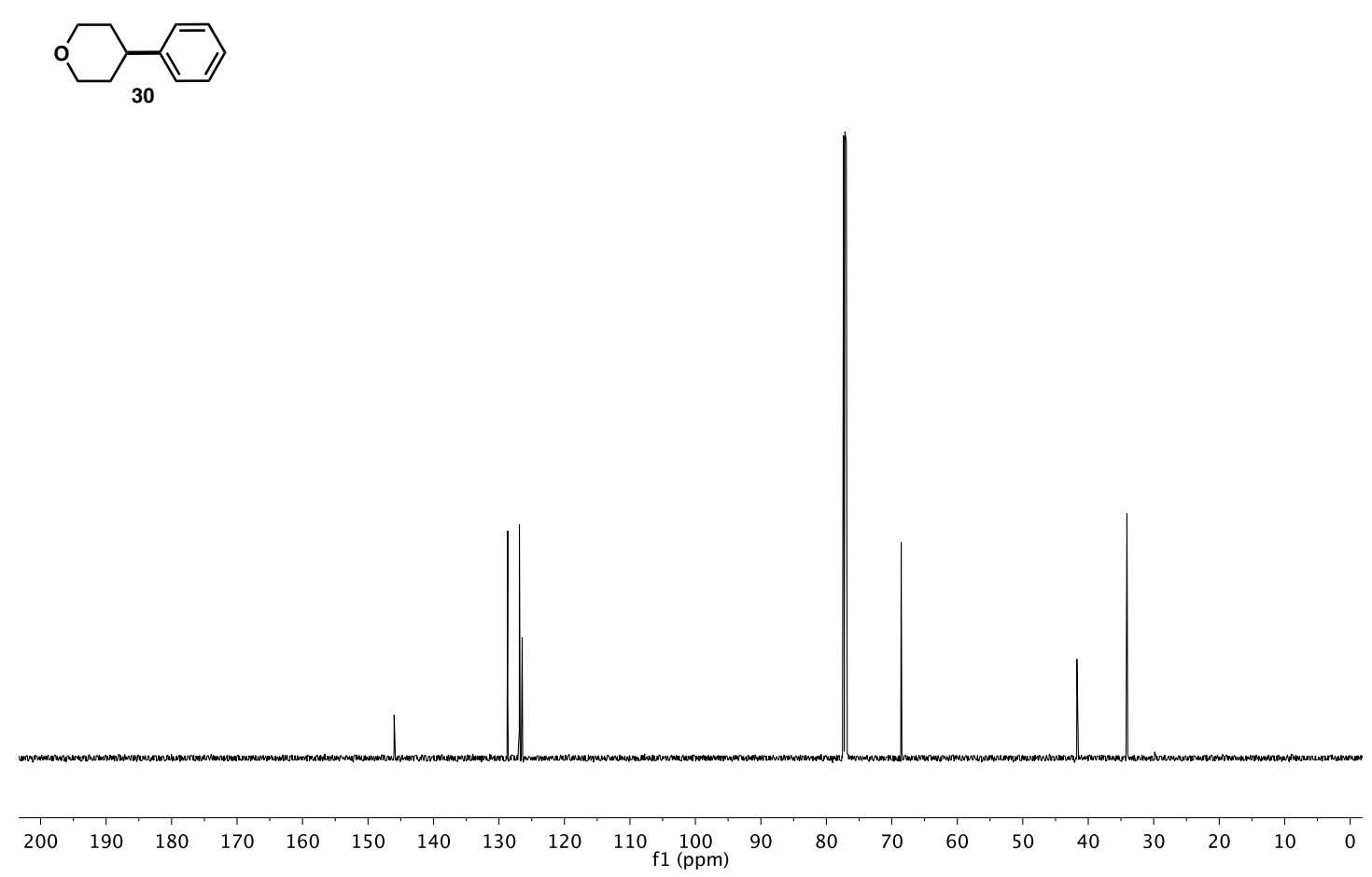<smiles>CCC(Br)c1cccnc1</smiles>

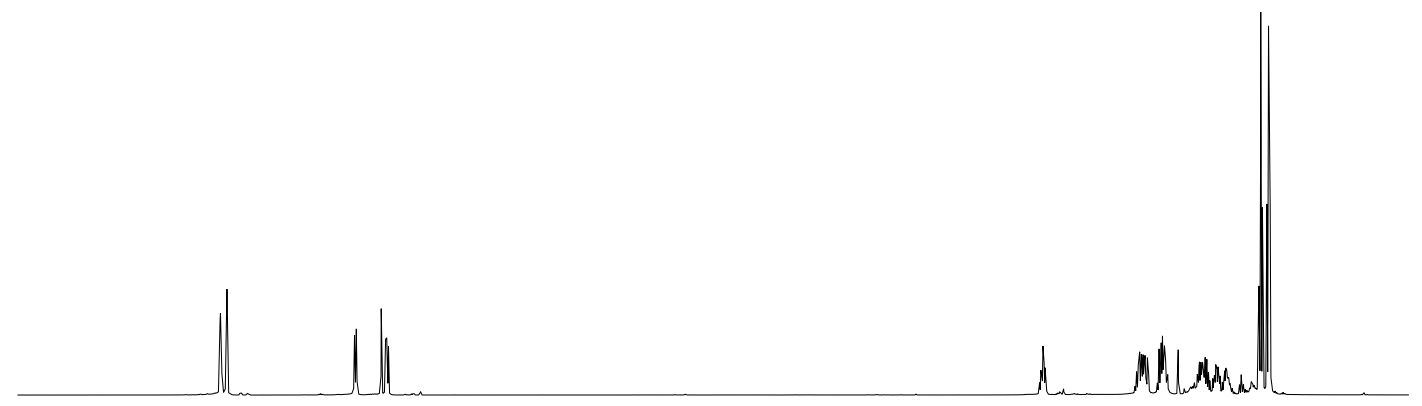

$\begin{array}{llllllllllllllllllll}9.5 & 9.0 & 8.5 & 8.0 & 7.5 & 7.0 & 6.5 & 6.0 & 5.5 & \begin{array}{l}5.0 \\ \mathrm{f} 1\end{array}(\mathrm{ppm}) & 4.5 & 4.0 & 3.5 & 3.0 & 2.5 & 2.0 & 1.5 & 1.0 & 0.5 & 0.0\end{array}$ 
<smiles>CCC(C)c1cccnc1</smiles>
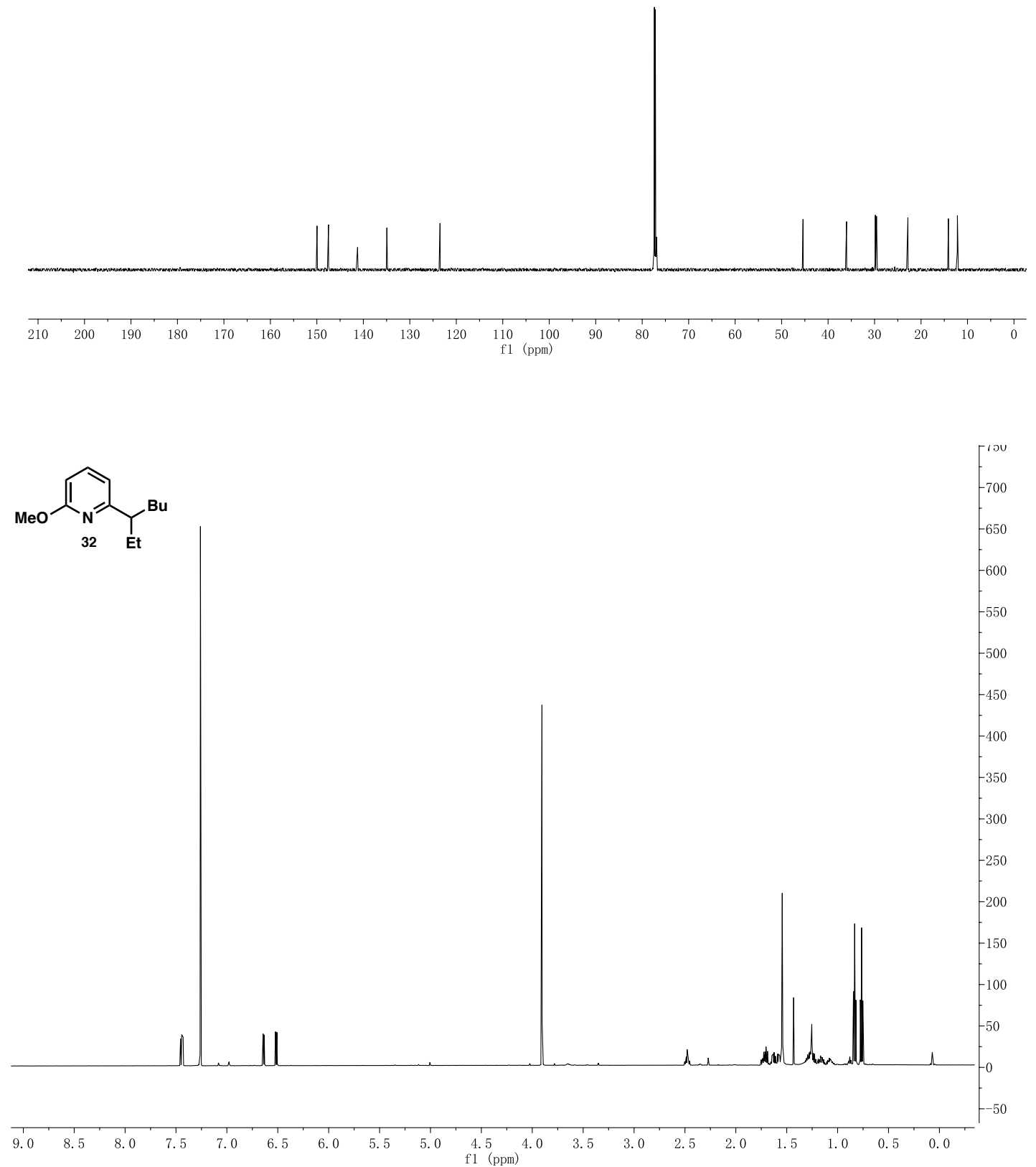

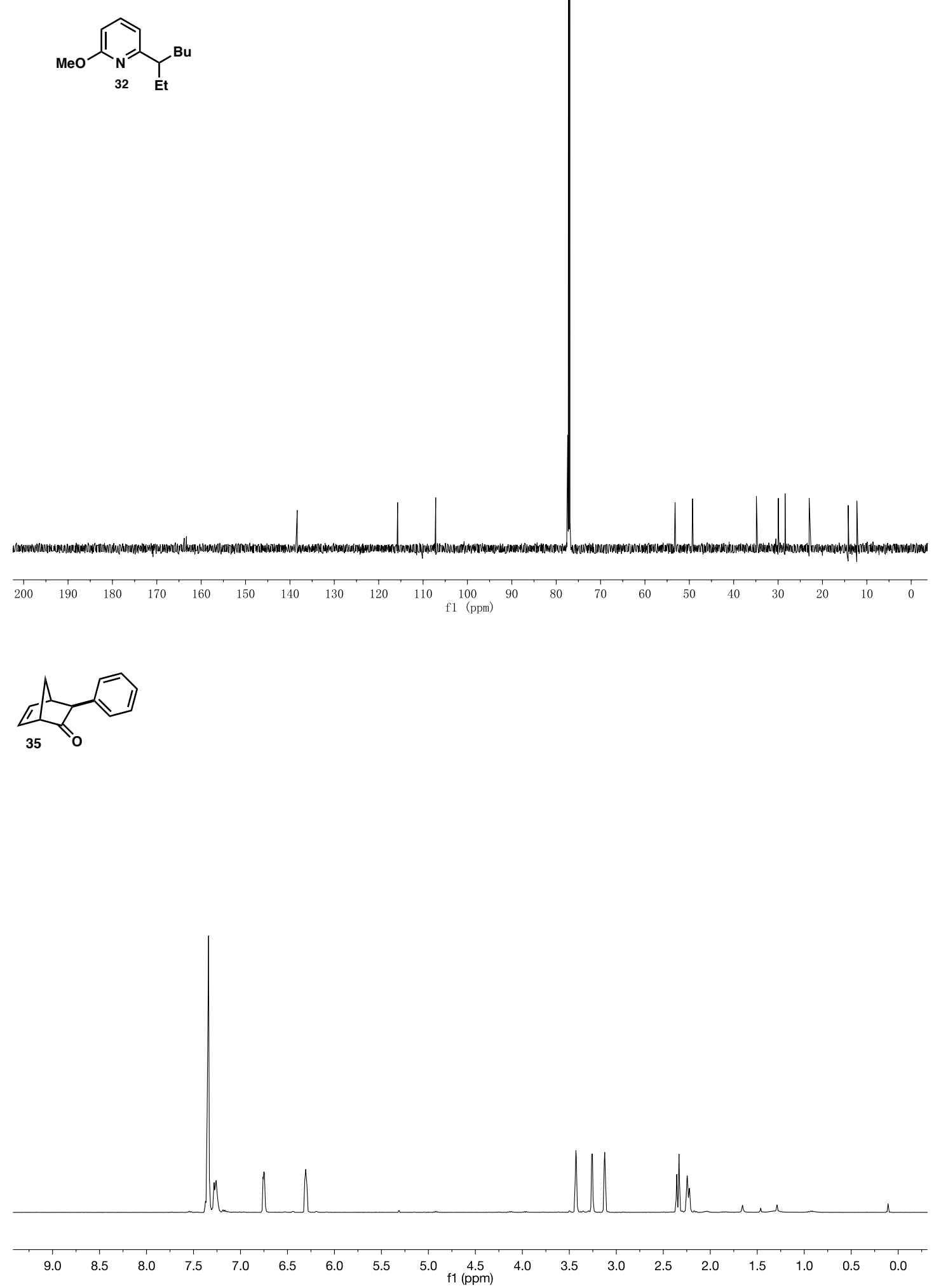

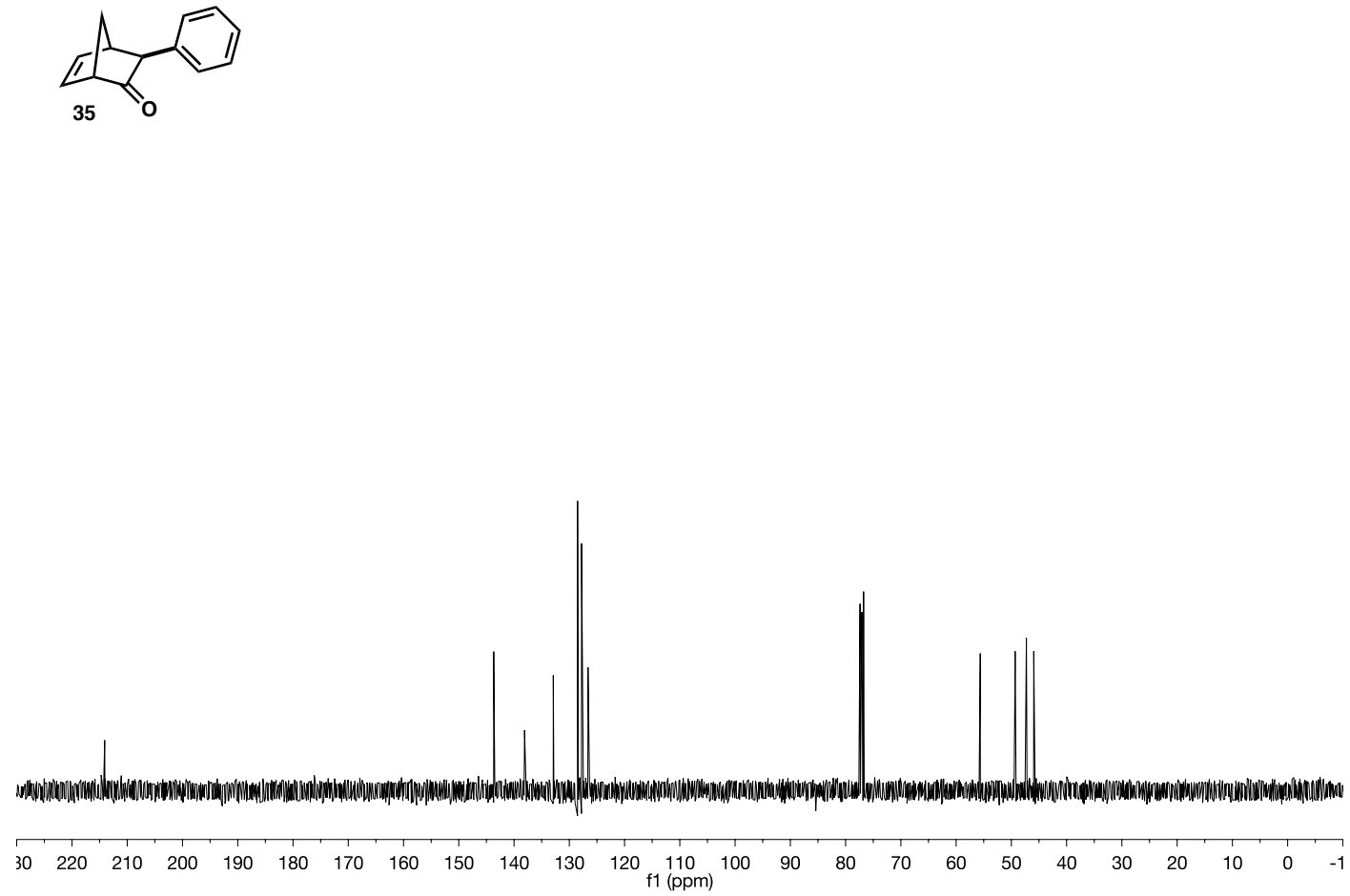

\section{Crystallographic data (X-Ray)}

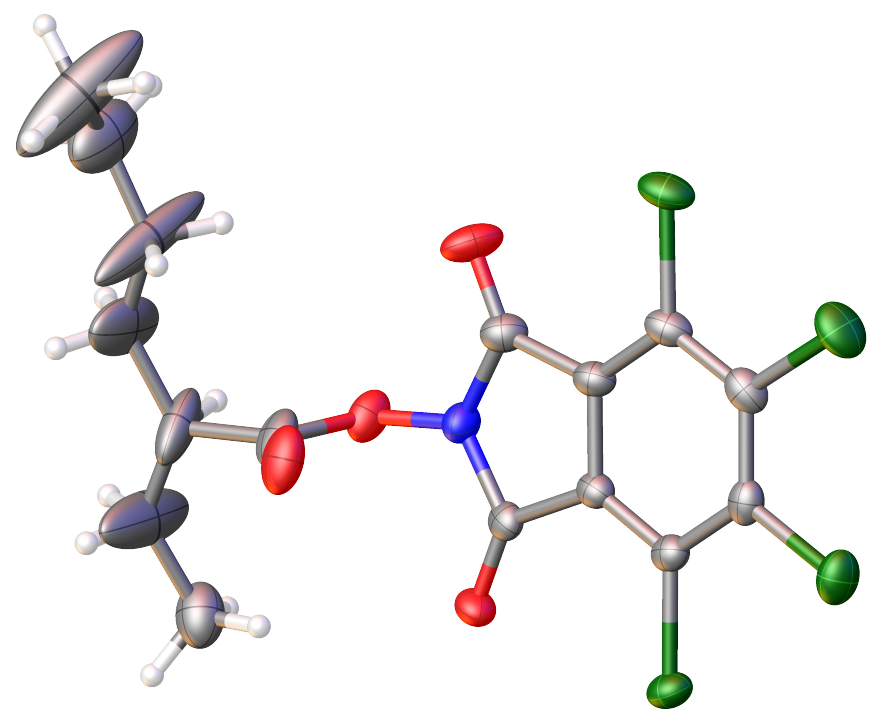

Table 1. Crystal data and structure refinement for $\mathbf{1 f}$. Identification code Empirical formula Formula weight

baran544

C16 H15 C14 N O4

427.09 
Temperature

Wavelength

Crystal system

Space group

Unit cell dimensions

Volume

Z

Density (calculated)

Absorption coefficient

$\mathrm{F}(000)$

Crystal size

Theta range for data collection

Index ranges

Reflections collected

Independent reflections

Completeness to theta $=25.242^{\circ}$

Absorption correction

Max. and min. transmission

Refinement method

Data / restraints / parameters

Goodness-of-fit on $\mathrm{F}^{2}$

Final $R$ indices [I $>2 \operatorname{sigma}(\mathrm{I})]$

$\mathrm{R}$ indices (all data)

Extinction coefficient

Largest diff. peak and hole
$296.15 \mathrm{~K}$

$0.71073 \AA$

Triclinic

$\mathrm{P}-1$

$\mathrm{a}=8.8700(7) \AA$

$\alpha=104.489(3)^{\circ}$.

$\mathrm{b}=9.1094(8) \AA$

$\beta=90.358(3)^{\circ}$.

$\mathrm{c}=12.6095(10) \AA$

$\gamma=111.767(3)^{\circ}$.

2

$1.558 \mathrm{Mg} / \mathrm{m}^{3}$

$0.671 \mathrm{~mm}^{-1}$

436

$0.29 \times 0.2 \times 0.08 \mathrm{~mm}^{3}$

2.488 to $26.358^{\circ}$.

$-10<=\mathrm{h}<=11,-11<=\mathrm{k}<=7,-15<=\mathrm{l}<=15$

11540

$3701[\mathrm{R}(\mathrm{int})=0.0324]$

$99.8 \%$

Semi-empirical from equivalents

0.2602 and 0.2261

Full-matrix least-squares on $\mathrm{F}^{2}$

$3701 / 0 / 228$

1.035

$\mathrm{R} 1=0.0544, \mathrm{wR} 2=0.1273$

$\mathrm{R} 1=0.0755, \mathrm{wR} 2=0.1400$

$\mathrm{n} / \mathrm{a}$

0.901 and -0.837 e. $\AA^{-3}$ 
Table 2. Atomic coordinates $\left(\times 10^{4}\right)$ and equivalent isotropic displacement parameters $\left(\AA^{2} \times 10^{3}\right)$ for baran544. $\mathrm{U}(\mathrm{eq})$ is defined as one third of the trace of the orthogonalized $\mathrm{U}^{\mathrm{ij}}$ tensor.

\begin{tabular}{|c|c|c|c|c|}
\hline & $\mathrm{x}$ & $\mathrm{y}$ & $\mathrm{z}$ & $\mathrm{U}(\mathrm{eq})$ \\
\hline $\mathrm{Cl}(1)$ & $9086(1)$ & $222(1)$ & $-1466(1)$ & $44(1)$ \\
\hline $\mathrm{Cl}(2)$ & $5403(1)$ & $-893(1)$ & $-2179(1)$ & $38(1)$ \\
\hline $\mathrm{Cl}(3)$ & $10837(1)$ & $3258(1)$ & $538(1)$ & $36(1)$ \\
\hline $\mathrm{Cl}(4)$ & $3434(1)$ & $1166(1)$ & $-994(1)$ & $31(1)$ \\
\hline $\mathrm{O}(1)$ & $6968(3)$ & $6648(3)$ & $2571(2)$ & $35(1)$ \\
\hline $\mathrm{O}(2)$ & $4321(3)$ & $4334(3)$ & $1022(2)$ & $31(1)$ \\
\hline $\mathrm{O}(3)$ & $9720(3)$ & $5834(3)$ & $2153(2)$ & $43(1)$ \\
\hline $\mathrm{N}(1)$ & $7043(3)$ & $5419(4)$ & $1697(2)$ & $29(1)$ \\
\hline $\mathrm{C}(1)$ & $8021(4)$ & $1334(4)$ & $-794(3)$ & $29(1)$ \\
\hline$C(2)$ & $8810(4)$ & 2697(4) & 104(3) & $28(1)$ \\
\hline$C(3)$ & $7922(4)$ & $3566(4)$ & $623(3)$ & $25(1)$ \\
\hline$C(4)$ & $8446(4)$ & $5060(4)$ & $1585(3)$ & $30(1)$ \\
\hline$C(5)$ & $6345(5)$ & $6042(5)$ & $3462(3)$ & $41(1)$ \\
\hline$C(6)$ & $6322(7)$ & $7428(7)$ & $4402(3)$ & $65(2)$ \\
\hline$C(7)$ & $7670(7)$ & $7904(7)$ & $5249(5)$ & $89(2)$ \\
\hline $\mathrm{C}(8)$ & $8981(11)$ & $7544(9)$ & $5301(6)$ & $160(5)$ \\
\hline $\mathrm{C}(9)$ & $10384(8)$ & $8132(8)$ & $6066(5)$ & $90(2)$ \\
\hline$C(10)$ & $10864(15)$ & $7225(8)$ & $6502(8)$ & $196(7)$ \\
\hline $\mathrm{C}(11)$ & $6361(4)$ & $846(4)$ & $-1126(3)$ & $26(1)$ \\
\hline$C(12)$ & $6275(4)$ & $3113(4)$ & $277(3)$ & $23(1)$ \\
\hline$C(13)$ & $5657(4)$ & $4287(4)$ & $1001(3)$ & $24(1)$ \\
\hline$C(14)$ & 4911(8) & $7661(10)$ & $4430(6)$ & $144(4)$ \\
\hline$C(15)$ & $3642(6)$ & $7289(6)$ & $3570(4)$ & $54(1)$ \\
\hline $\mathrm{O}(16)$ & $5931(4)$ & $4635(4)$ & $3423(2)$ & $49(1)$ \\
\hline$C(17)$ & $5473(4)$ & $1756(4)$ & $-592(3)$ & $24(1)$ \\
\hline
\end{tabular}


Table 3. Bond lengths $[\AA]$ and angles $\left[{ }^{\circ}\right]$ for baran 544 .

\begin{tabular}{|c|c|}
\hline $\mathrm{Cl}(1)-\mathrm{C}(1)$ & $1.712(3)$ \\
\hline $\mathrm{Cl}(2)-\mathrm{C}(11)$ & $1.712(3)$ \\
\hline $\mathrm{Cl}(3)-\mathrm{C}(2)$ & $1.720(3)$ \\
\hline $\mathrm{Cl}(4)-\mathrm{C}(17)$ & $1.717(3)$ \\
\hline $\mathrm{O}(1)-\mathrm{N}(1)$ & $1.383(4)$ \\
\hline $\mathrm{O}(1)-\mathrm{C}(5)$ & $1.401(5)$ \\
\hline $\mathrm{O}(2)-\mathrm{C}(13)$ & $1.202(4)$ \\
\hline $\mathrm{O}(3)-\mathrm{C}(4)$ & $1.197(4)$ \\
\hline $\mathrm{N}(1)-\mathrm{C}(4)$ & $1.398(4)$ \\
\hline N(1)-C(13) & $1.392(4)$ \\
\hline$C(1)-C(2)$ & $1.398(5)$ \\
\hline$C(1)-C(11)$ & $1.398(5)$ \\
\hline$C(2)-C(3)$ & $1.373(5)$ \\
\hline$C(3)-C(4)$ & $1.496(5)$ \\
\hline $\mathrm{C}(3)-\mathrm{C}(12)$ & $1.396(4)$ \\
\hline$C(5)-C(6)$ & $1.507(5)$ \\
\hline $\mathrm{C}(5)-\mathrm{O}(16)$ & $1.183(5)$ \\
\hline $\mathrm{C}(6)-\mathrm{H}(6)$ & 0.9800 \\
\hline$C(6)-C(7)$ & $1.458(7)$ \\
\hline$C(6)-C(14)$ & $1.344(7)$ \\
\hline $\mathrm{C}(7)-\mathrm{H}(7 \mathrm{~A})$ & 0.9700 \\
\hline $\mathrm{C}(7)-\mathrm{H}(7 \mathrm{~B})$ & 0.9700 \\
\hline$C(7)-C(8)$ & $1.326(8)$ \\
\hline $\mathrm{C}(8)-\mathrm{H}(8 \mathrm{~A})$ & 0.9700 \\
\hline $\mathrm{C}(8)-\mathrm{H}(8 \mathrm{~B})$ & 0.9700 \\
\hline$C(8)-C(9)$ & $1.414(8)$ \\
\hline $\mathrm{C}(9)-\mathrm{H}(9 \mathrm{~A})$ & 0.9700 \\
\hline C(9)-H(9B) & 0.9700 \\
\hline C(9)-C(10) & $1.284(8)$ \\
\hline $\mathrm{C}(10)-\mathrm{H}(10 \mathrm{~A})$ & 0.9600 \\
\hline $\mathrm{C}(10)-\mathrm{H}(10 \mathrm{~B})$ & 0.9600 \\
\hline $\mathrm{C}(10)-\mathrm{H}(10 \mathrm{C})$ & 0.9600 \\
\hline C(11)-C(17) & $1.405(5)$ \\
\hline$C(12)-C(13)$ & $1.493(5)$ \\
\hline$C(12)-C(17)$ & $1.376(5)$ \\
\hline $\mathrm{C}(14)-\mathrm{H}(14 \mathrm{~A})$ & 0.9700 \\
\hline
\end{tabular}




\begin{tabular}{|c|c|}
\hline $\mathrm{C}(14)-\mathrm{H}(14 \mathrm{~B})$ & 0.9700 \\
\hline $\mathrm{C}(14)-\mathrm{C}(15)$ & $1.441(8)$ \\
\hline $\mathrm{C}(15)-\mathrm{H}(15 \mathrm{~A})$ & 0.9600 \\
\hline $\mathrm{C}(15)-\mathrm{H}(15 \mathrm{~B})$ & 0.9600 \\
\hline $\mathrm{C}(15)-\mathrm{H}(15 \mathrm{C})$ & 0.9600 \\
\hline $\mathrm{N}(1)-\mathrm{O}(1)-\mathrm{C}(5)$ & 111.7(3) \\
\hline $\mathrm{O}(1)-\mathrm{N}(1)-\mathrm{C}(4)$ & $121.4(3)$ \\
\hline $\mathrm{O}(1)-\mathrm{N}(1)-\mathrm{C}(13)$ & $121.9(3)$ \\
\hline $\mathrm{C}(13)-\mathrm{N}(1)-\mathrm{C}(4)$ & $115.7(3)$ \\
\hline $\mathrm{C}(2)-\mathrm{C}(1)-\mathrm{Cl}(1)$ & $119.5(3)$ \\
\hline $\mathrm{C}(11)-\mathrm{C}(1)-\mathrm{Cl}(1)$ & $119.8(3)$ \\
\hline $\mathrm{C}(11)-\mathrm{C}(1)-\mathrm{C}(2)$ & $120.6(3)$ \\
\hline $\mathrm{C}(1)-\mathrm{C}(2)-\mathrm{Cl}(3)$ & $120.6(3)$ \\
\hline $\mathrm{C}(3)-\mathrm{C}(2)-\mathrm{Cl}(3)$ & $121.4(3)$ \\
\hline$C(3)-C(2)-C(1)$ & 118.1(3) \\
\hline$C(2)-C(3)-C(4)$ & $129.5(3)$ \\
\hline $\mathrm{C}(2)-\mathrm{C}(3)-\mathrm{C}(12)$ & $121.6(3)$ \\
\hline$C(12)-C(3)-C(4)$ & $108.9(3)$ \\
\hline $\mathrm{O}(3)-\mathrm{C}(4)-\mathrm{N}(1)$ & $125.2(3)$ \\
\hline $\mathrm{O}(3)-\mathrm{C}(4)-\mathrm{C}(3)$ & $131.8(3)$ \\
\hline N(1)-C(4)-C(3) & $103.0(3)$ \\
\hline $\mathrm{O}(1)-\mathrm{C}(5)-\mathrm{C}(6)$ & $109.8(4)$ \\
\hline $\mathrm{O}(16)-\mathrm{C}(5)-\mathrm{O}(1)$ & $121.8(3)$ \\
\hline $\mathrm{O}(16)-\mathrm{C}(5)-\mathrm{C}(6)$ & $128.4(4)$ \\
\hline $\mathrm{C}(5)-\mathrm{C}(6)-\mathrm{H}(6)$ & 95.4 \\
\hline$C(7)-C(6)-C(5)$ & $110.2(4)$ \\
\hline $\mathrm{C}(7)-\mathrm{C}(6)-\mathrm{H}(6)$ & 95.4 \\
\hline$C(14)-C(6)-C(5)$ & $115.1(4)$ \\
\hline $\mathrm{C}(14)-\mathrm{C}(6)-\mathrm{H}(6)$ & 95.4 \\
\hline$C(14)-C(6)-C(7)$ & $132.0(5)$ \\
\hline $\mathrm{C}(6)-\mathrm{C}(7)-\mathrm{H}(7 \mathrm{~A})$ & 103.6 \\
\hline $\mathrm{C}(6)-\mathrm{C}(7)-\mathrm{H}(7 \mathrm{~B})$ & 103.6 \\
\hline $\mathrm{H}(7 \mathrm{~A})-\mathrm{C}(7)-\mathrm{H}(7 \mathrm{~B})$ & 105.3 \\
\hline $\mathrm{C}(8)-\mathrm{C}(7)-\mathrm{C}(6)$ & $134.3(5)$ \\
\hline $\mathrm{C}(8)-\mathrm{C}(7)-\mathrm{H}(7 \mathrm{~A})$ & 103.6 \\
\hline $\mathrm{C}(8)-\mathrm{C}(7)-\mathrm{H}(7 \mathrm{~B})$ & 103.6 \\
\hline $\mathrm{C}(7)-\mathrm{C}(8)-\mathrm{H}(8 \mathrm{~A})$ & 103.5 \\
\hline
\end{tabular}




\begin{tabular}{|c|c|}
\hline $\mathrm{C}(7)-\mathrm{C}(8)-\mathrm{H}(8 \mathrm{~B})$ & 103.5 \\
\hline $\mathrm{C}(7)-\mathrm{C}(8)-\mathrm{C}(9)$ & $134.7(5)$ \\
\hline $\mathrm{H}(8 \mathrm{~A})-\mathrm{C}(8)-\mathrm{H}(8 \mathrm{~B})$ & 105.3 \\
\hline $\mathrm{C}(9)-\mathrm{C}(8)-\mathrm{H}(8 \mathrm{~A})$ & 103.5 \\
\hline $\mathrm{C}(9)-\mathrm{C}(8)-\mathrm{H}(8 \mathrm{~B})$ & 103.5 \\
\hline $\mathrm{C}(8)-\mathrm{C}(9)-\mathrm{H}(9 \mathrm{~A})$ & 106.2 \\
\hline $\mathrm{C}(8)-\mathrm{C}(9)-\mathrm{H}(9 \mathrm{~B})$ & 106.2 \\
\hline $\mathrm{H}(9 \mathrm{~A})-\mathrm{C}(9)-\mathrm{H}(9 \mathrm{~B})$ & 106.3 \\
\hline$C(10)-C(9)-C(8)$ & $124.7(7)$ \\
\hline $\mathrm{C}(10)-\mathrm{C}(9)-\mathrm{H}(9 \mathrm{~A})$ & 106.2 \\
\hline $\mathrm{C}(10)-\mathrm{C}(9)-\mathrm{H}(9 \mathrm{~B})$ & 106.2 \\
\hline $\mathrm{C}(9)-\mathrm{C}(10)-\mathrm{H}(10 \mathrm{~A})$ & 109.5 \\
\hline $\mathrm{C}(9)-\mathrm{C}(10)-\mathrm{H}(10 \mathrm{~B})$ & 109.5 \\
\hline $\mathrm{C}(9)-\mathrm{C}(10)-\mathrm{H}(10 \mathrm{C})$ & 109.5 \\
\hline $\mathrm{H}(10 \mathrm{~A})-\mathrm{C}(10)-\mathrm{H}(10 \mathrm{~B})$ & 109.5 \\
\hline $\mathrm{H}(10 \mathrm{~A})-\mathrm{C}(10)-\mathrm{H}(10 \mathrm{C})$ & 109.5 \\
\hline $\mathrm{H}(10 \mathrm{~B})-\mathrm{C}(10)-\mathrm{H}(10 \mathrm{C})$ & 109.5 \\
\hline $\mathrm{C}(1)-\mathrm{C}(11)-\mathrm{Cl}(2)$ & $119.5(3)$ \\
\hline$C(1)-C(11)-C(17)$ & $120.5(3)$ \\
\hline $\mathrm{C}(17)-\mathrm{C}(11)-\mathrm{Cl}(2)$ & $119.9(3)$ \\
\hline $\mathrm{C}(3)-\mathrm{C}(12)-\mathrm{C}(13)$ & $108.9(3)$ \\
\hline$C(17)-C(12)-C(3)$ & $121.0(3)$ \\
\hline$C(17)-C(12)-C(13)$ & $130.1(3)$ \\
\hline $\mathrm{O}(2)-\mathrm{C}(13)-\mathrm{N}(1)$ & $125.2(3)$ \\
\hline $\mathrm{O}(2)-\mathrm{C}(13)-\mathrm{C}(12)$ & $131.5(3)$ \\
\hline $\mathrm{N}(1)-\mathrm{C}(13)-\mathrm{C}(12)$ & $103.3(3)$ \\
\hline $\mathrm{C}(6)-\mathrm{C}(14)-\mathrm{H}(14 \mathrm{~A})$ & 104.4 \\
\hline $\mathrm{C}(6)-\mathrm{C}(14)-\mathrm{H}(14 \mathrm{~B})$ & 104.4 \\
\hline$C(6)-C(14)-C(15)$ & $131.4(6)$ \\
\hline $\mathrm{H}(14 \mathrm{~A})-\mathrm{C}(14)-\mathrm{H}(14 \mathrm{~B})$ & 105.6 \\
\hline $\mathrm{C}(15)-\mathrm{C}(14)-\mathrm{H}(14 \mathrm{~A})$ & 104.4 \\
\hline $\mathrm{C}(15)-\mathrm{C}(14)-\mathrm{H}(14 \mathrm{~B})$ & 104.4 \\
\hline $\mathrm{C}(14)-\mathrm{C}(15)-\mathrm{H}(15 \mathrm{~A})$ & 109.5 \\
\hline $\mathrm{C}(14)-\mathrm{C}(15)-\mathrm{H}(15 \mathrm{~B})$ & 109.5 \\
\hline $\mathrm{C}(14)-\mathrm{C}(15)-\mathrm{H}(15 \mathrm{C})$ & 109.5 \\
\hline $\mathrm{H}(15 \mathrm{~A})-\mathrm{C}(15)-\mathrm{H}(15 \mathrm{~B})$ & 109.5 \\
\hline $\mathrm{H}(15 \mathrm{~A})-\mathrm{C}(15)-\mathrm{H}(15 \mathrm{C})$ & 109.5 \\
\hline $\mathrm{H}(15 \mathrm{~B})-\mathrm{C}(15)-\mathrm{H}(15 \mathrm{C})$ & 109.5 \\
\hline
\end{tabular}


$\mathrm{C}(11)-\mathrm{C}(17)-\mathrm{Cl}(4)$

$120.8(3)$

$\mathrm{C}(12)-\mathrm{C}(17)-\mathrm{Cl}(4)$

$121.0(3)$

$\mathrm{C}(12)-\mathrm{C}(17)-\mathrm{C}(11)$

118.1(3)

Symmetry transformations used to generate equivalent atoms: 
Table 4. Anisotropic displacement parameters $\left(\AA^{2} \times 10^{3}\right)$ for baran544. The anisotropic displacement factor exponent takes the form: $-2 \pi^{2}\left[h^{2} a^{* 2} U^{11}+\ldots+2 h k a^{*} b^{*} U^{12}\right]$

\begin{tabular}{|c|c|c|c|c|c|c|}
\hline & $\mathrm{U}^{11}$ & $\mathrm{U}^{22}$ & $\mathrm{U}^{33}$ & $\mathrm{U}^{23}$ & $\mathrm{U}^{13}$ & $\mathrm{U}^{12}$ \\
\hline $\mathrm{Cl}(1)$ & $50(1)$ & $42(1)$ & $54(1)$ & $16(1)$ & $19(1)$ & $32(1)$ \\
\hline $\mathrm{Cl}(2)$ & $52(1)$ & $28(1)$ & $31(1)$ & $4(1)$ & $4(1)$ & $14(1)$ \\
\hline $\mathrm{Cl}(3)$ & $23(1)$ & $39(1)$ & $57(1)$ & $24(1)$ & $7(1)$ & $16(1)$ \\
\hline $\mathrm{Cl}(4)$ & $25(1)$ & $35(1)$ & $31(1)$ & $10(1)$ & $-4(1)$ & $9(1)$ \\
\hline $\mathrm{O}(1)$ & $51(2)$ & $28(1)$ & $29(1)$ & $2(1)$ & $-3(1)$ & $22(1)$ \\
\hline $\mathrm{O}(2)$ & $25(1)$ & $43(1)$ & $30(1)$ & $11(1)$ & $5(1)$ & $19(1)$ \\
\hline $\mathrm{O}(3)$ & $31(1)$ & $31(1)$ & $57(2)$ & $5(1)$ & $-17(1)$ & $7(1)$ \\
\hline $\mathrm{N}(1)$ & $30(2)$ & $32(2)$ & $25(2)$ & $2(1)$ & $1(1)$ & $15(1)$ \\
\hline$C(1)$ & $34(2)$ & $27(2)$ & $36(2)$ & $17(2)$ & $12(2)$ & $17(2)$ \\
\hline$C(2)$ & $23(2)$ & $28(2)$ & $40(2)$ & $19(2)$ & $6(2)$ & $12(1)$ \\
\hline$C(3)$ & $22(2)$ & $25(2)$ & $31(2)$ & $14(2)$ & $2(1)$ & $9(1)$ \\
\hline $\mathrm{C}(4)$ & $27(2)$ & $27(2)$ & $37(2)$ & $12(2)$ & $-1(2)$ & $10(2)$ \\
\hline$C(5)$ & $64(3)$ & $47(2)$ & $23(2)$ & $6(2)$ & $-5(2)$ & $36(2)$ \\
\hline$C(6)$ & $116(4)$ & 73(3) & $25(2)$ & $-7(2)$ & $-11(2)$ & $70(3)$ \\
\hline$C(7)$ & 71(4) & $78(4)$ & $83(4)$ & $-54(3)$ & $-22(3)$ & $38(3)$ \\
\hline $\mathrm{C}(8)$ & $218(9)$ & $119(6)$ & $137(6)$ & $-99(5)$ & $-141(6)$ & $145(6)$ \\
\hline $\mathrm{C}(9)$ & $107(5)$ & $84(4)$ & $76(4)$ & $-24(3)$ & $-18(4)$ & $64(4)$ \\
\hline$C(10)$ & $348(15)$ & 63(4) & $155(8)$ & $-41(5)$ & $-173(10)$ & $103(7)$ \\
\hline$C(11)$ & $37(2)$ & $22(2)$ & $23(2)$ & $10(1)$ & $6(1)$ & $12(1)$ \\
\hline $\mathrm{C}(12)$ & $23(2)$ & $27(2)$ & $24(2)$ & $13(1)$ & $4(1)$ & $12(1)$ \\
\hline$C(13)$ & $27(2)$ & $29(2)$ & $21(2)$ & $12(1)$ & $4(1)$ & $13(1)$ \\
\hline$C(14)$ & $86(5)$ & $162(7)$ & $136(6)$ & $-109(6)$ & $-51(4)$ & $91(5)$ \\
\hline$C(15)$ & $76(3)$ & $59(3)$ & $42(3)$ & $18(2)$ & $12(2)$ & $40(3)$ \\
\hline $\mathrm{O}(16)$ & $83(2)$ & $45(2)$ & $28(2)$ & $14(1)$ & $6(1)$ & $31(2)$ \\
\hline $\mathrm{C}(17)$ & $25(2)$ & $27(2)$ & $24(2)$ & $12(1)$ & $2(1)$ & $9(1)$ \\
\hline
\end{tabular}


Table 5. Hydrogen coordinates $\left(\times 10^{4}\right)$ and isotropic displacement parameters $\left(\AA^{2} \times 10^{3}\right)$ for baran544.

\begin{tabular}{|c|c|c|c|c|}
\hline & $\mathrm{x}$ & $\mathrm{y}$ & $\mathrm{z}$ & $\mathrm{U}(\mathrm{eq})$ \\
\hline $\mathrm{H}(6)$ & 6879 & 8299 & 4050 & 78 \\
\hline $\mathrm{H}(7 \mathrm{~A})$ & 8112 & 9094 & 5441 & 107 \\
\hline $\mathrm{H}(7 \mathrm{~B})$ & 7129 & 7618 & 5877 & 107 \\
\hline $\mathrm{H}(8 \mathrm{~A})$ & 9428 & 7667 & 4614 & 192 \\
\hline $\mathrm{H}(8 \mathrm{~B})$ & 8530 & 6371 & 5220 & 192 \\
\hline $\mathrm{H}(9 \mathrm{~A})$ & 11294 & 8717 & 5711 & 108 \\
\hline $\mathrm{H}(9 \mathrm{~B})$ & 10249 & 8951 & 6674 & 108 \\
\hline $\mathrm{H}(10 \mathrm{~A})$ & 11149 & 6478 & 5937 & 294 \\
\hline $\mathrm{H}(10 \mathrm{~B})$ & 10001 & 6614 & 6865 & 294 \\
\hline $\mathrm{H}(10 \mathrm{C})$ & 11801 & 7906 & 7029 & 294 \\
\hline $\mathrm{H}(14 \mathrm{~A})$ & 5233 & 8826 & 4778 & 173 \\
\hline $\mathrm{H}(14 \mathrm{~B})$ & 4347 & 7111 & 4964 & 173 \\
\hline $\mathrm{H}(15 \mathrm{~A})$ & 3575 & 6332 & 3005 & 80 \\
\hline $\mathrm{H}(15 \mathrm{~B})$ & 3890 & 8203 & 3260 & 80 \\
\hline $\mathrm{H}(15 \mathrm{C})$ & 2616 & 7086 & 3871 & 80 \\
\hline
\end{tabular}




\section{References}

${ }^{1}$ Gianatassio, R.; Kawamura, S.; Eprile, C. L.; Foo, K.; Ge, J.; Burns, A. C.; Collins, M. R.; Baran, P. S. Angew. Chem. Int, Ed. 2014, 53, 9851.

${ }^{2}$ Zeller, A.; Herdtweck, E., Strassner, T. Eur. J. Inorg. Chem. 2003, 1802.

${ }^{3}$ Sugamoto, K.; Matsushita, Y.; Kameda, Y.; Suzuki, M.; Matsui, T. Synth. Comm. 2005, 35, $67-70$.

${ }^{4}$ Hettche, F.; Hoffmann, R. W. New J. Chem. 2003, 27, 172.

${ }^{5}$ Piller, F. M.; Appukkuttan, P.; Gavryushin, A.; Helm M.; Knochel, P. Angew. Chem. Int. Ed. 2008, 47, 6802; (b) Piller F. M.; Metzger, A.; Schade, M. A.; Haag, B. A.; Gavryushin, A.; Knochel, P.Chem. Eur. J. 2009, 15, 7192.

${ }^{6}$ When HATU is formed, a certain degree of $N$-acyl migration might occur. For a description of this phenomenon, see: Carpino, L. A.; Imazumi, H.; El-Faham, A.; Ferrer, F. J.; Zhang, C.; Lee, Y.; Foxman, B. M.; Henklein, P.; Hanay, C.; Mügge, C.; Wenschuh, H.; Klose, J.; Beyermann, Bienert, M. Angew. Chem. Int. Ed. 2002, 41, 441.

${ }^{7}$ Vechorkin, O.; Proust, V.; Hu, X. J. Am. Chem. Soc. 2009, 131, 9756.

${ }^{8}$ Schley, N. D.; Fu, G. C.; J. Am. Chem. Soc. 2014, 136, 16588 